Florida International University FIU Digital Commons

$11-13-2013$

\title{
The Dark Side of Globalization: The Transnationalization of Garrisons in the Case of Jamaica
}

Michelle Angela Munroe

m_munroe_98@yahoo.com

DOI: $10.25148 /$ etd.FI13120610

Follow this and additional works at: https://digitalcommons.fiu.edu/etd

Part of the Comparative Politics Commons, and the International Relations Commons

\section{Recommended Citation}

Munroe, Michelle Angela, "The Dark Side of Globalization: The Transnationalization of Garrisons in the Case of Jamaica" (2013). FIU Electronic Theses and Dissertations. 996.

https://digitalcommons.fiu.edu/etd/996 


\title{
FLORIDA INTERNATIONAL UNIVERSITY
}

Miami, Florida

THE DARK SIDE OF GLOBALIZATION: THE TRANSNATIONALIZATION OF GARRISONS IN THE CASE OF JAMAICA

\author{
A dissertation submitted in partial fulfillment of \\ the requirements for the degree of \\ DOCTOR OF PHILOSOPHY \\ in \\ POLITICAL SCIENCE \\ by
}

Michelle Angela Munroe

2013 
To: Dean Kenneth G. Furton

College of Arts and Science

This dissertation, written by Michelle Angela Munroe, and entitled The Dark Side of Globalization: The Transnationalization of Garrisons in the Case of Jamaica, having been approved in respect to style and intellectual content, is referred to you for judgment.

We have read this dissertation and recommend that it be approved.

Ronald W. Cox

Felix Martin

Nicol C. Rae

Howard Frank

John F. Stack Jr., Major Professor

Date of Defense: November 13, 2013

The dissertation of Michelle Angela Munroe is approved.

$\begin{array}{r}\begin{array}{r}\text { Dean Kenneth G. Furton } \\ \text { College of Arts and Sciences }\end{array} \\ \hline \begin{array}{r}\text { Dean Lakshmi N. Reddi } \\ \text { University Graduate School }\end{array}\end{array}$

Florida International University, 2013 


\section{ACKNOWLEDGMENTS}

I would first like to thank my parents Palma and Earl Munroe for their patience, understanding, encouragement, and unconditional love. Without their continued support the completion of this work would not have been possible-I love you both.

I would also like to thank Melissa Huseby, a good friend, for being my sounding board over the years and for being there when times got tough. As Oprah said, "Lots of people want to ride with you in the limo, but what you want is someone who will take the bus with you when the limo breaks down."--Thank you.

I would like to express my deepest gratitude to my advisor, Dr. John Stack, for his guidance and advice. I am eternally grateful for his comments and feedback and for dedicating large chunks of his time to patiently reading my dissertation line-by-line, word-by-word, and for questioning every line and every world. His constant push for excellence has taught me to look beyond the obvious and to embrace the complex. Special thanks goes to Dr. Cox for his assistance in helping me to conceptualize my work from the beginning of my journey. I am extremely thankful to all the members of my dissertation committee for their suggestions and questions at every evaluation. All your concerns and advice played a huge role is shaping and framing the direction of my research.

Finally, I would like to thank the Department of Politics and International Relations at Florida International University for granting me a Graduate Teaching Assistantship and allowing me the opportunity to obtain a graduate degree. The Jack D. Gordon Institute for Public Policy and Citizenship Studies for the privilege of learning a 
foreign language first hand through their National Security Studies (PINSS) Foreign

Language and Cultural Immersion Scholarship. Last, but my no means least, I am indebted to the financial support of the FIU Dissertation Evidence Acquisition (DEA)

Fellowship and the Anita Broad Research Award (FIU) for allowing me some reprieve in bringing this long and challenging journey to an end. 
ABSTRACT OF THE DISSERTATION

THE DARK SIDE OF GLOBALIZATION: THE TRANSNATIONALIZATION OF

GARRISONS IN THE CASE OF JAMAICA

by

Michelle Angela Munroe

Florida International University, 2013

Miami, Florida

Professor John F. Stack Jr., Major Professor

The current study is concerned with the role that transnational criminal organizations play in the ability of a small country, such as Jamaica, to govern itself effectively. Jamaica is identified as a major producer and distributor of cannabis, since the 1970s, and today plays an active role in other established illicit markets for cocaine and illegal weapons. Despite a long-term and continued involvement in U.S. funded drug trafficking and counterdrug programs, and the establishment of several anti-crime organizations within the country, Jamaica's successes have been marginal. The current study attempts to examine first, how criminal groups located within the garrisons of Kingston have managed to strengthen their involvement in illegal activities and to evade the state. Second, it explores how these criminal groups have successfully offset the Jamaican state's monopoly on power within garrison communities.

Through a qualitative research design, I utilized a wide range of research methods- observation, open-ended interviews, focus groups, document data, audio-visual data, and text and image analysis- in order to identify the mechanisms by which non-state actors have been able to alter their power relation with the state. The study explores the 
relationship between the Jamaican state and criminal groups residing within garrisons specifically located in the Kingston Metropolitan Area.

The study concludes that the interactions between garrisons and the Jamaican state have become increasingly more transnational over time. Using Nye and Keohane's (1971) understanding of transnational relations in an analysis of the garrison, the dissertation asserts that network based criminal groupings residing within garrisons are directly shaping the behavior and policy goals of the Jamaican state by forming coalitions and interactions across state boundaries. These coalitions and interactions involve a wide cross section of non-state actors both criminal and legal, as well as corruptible elements of government. Network based criminal groupings located with Jamaica's garrisons are increasingly competent in evading the law and in carrying out criminal activity. They do so by employing more fluid organizational and power structures, assuming a more influential role in the distribution and use of violence, and by taking advantage of the liberalization and privatization of the Jamaican economy. 


\section{TABLE OF CONTENTS}

CHAPTER

PAGE

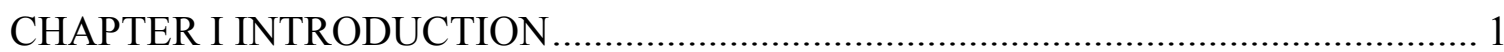

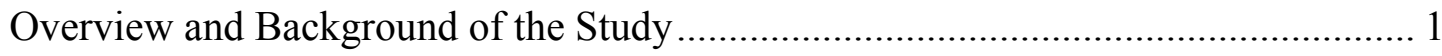

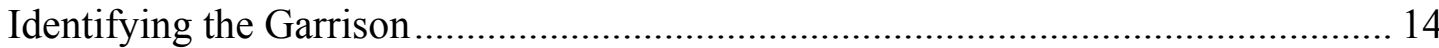

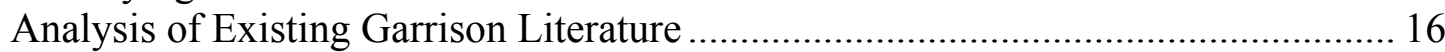

Identifying the Garrison from a transnational scale.................................................. 22

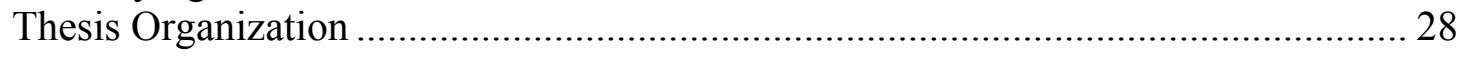

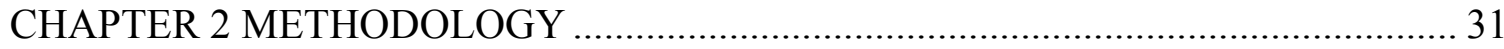

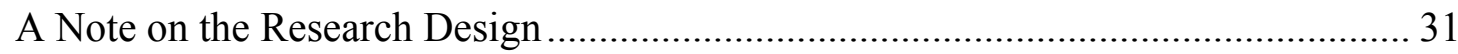

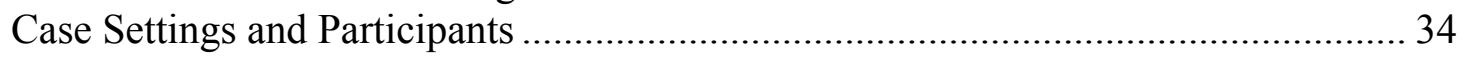

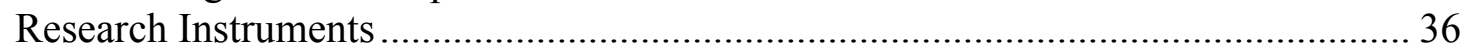

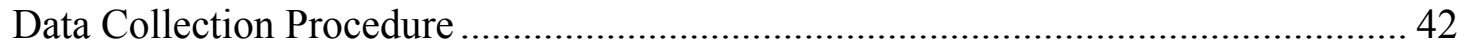

Confidentiality, Ethical Concerns, and Limitations..................................................... 48

CHAPTER 3 FROM THE GLOBAL TO THE LOCAL_...............................................59

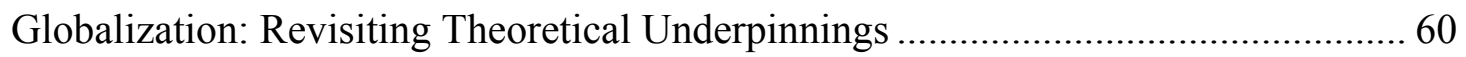

Moving towards a Transnational Approach to state Interaction.................................... 71

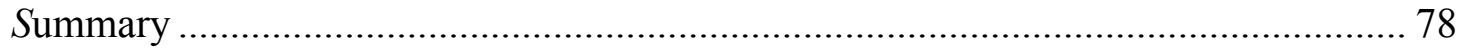

CHAPTER 4 FROM GANGS TO GARRISONS: 1940s TO 1970s............................... 80

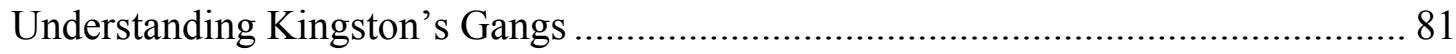

Gang Formation within the Context of Politics ........................................................... 85

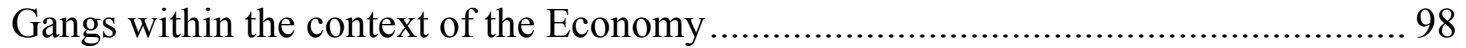

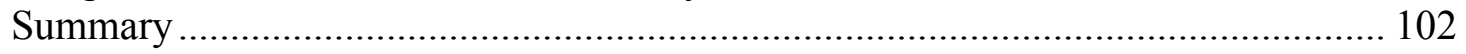

CHAPTER 5 A TYPOLOGY OF THE GARRISON AND IT'S TRANSNATIONAL

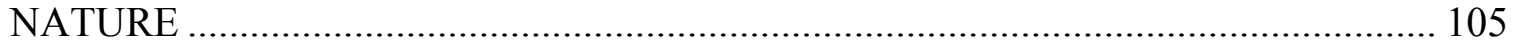

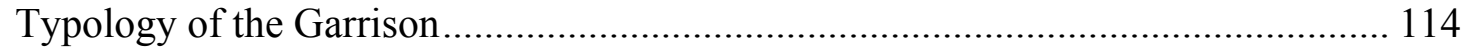

The Role of Urban Gangs within the Garrison ........................................................ 127

A Typology of Jamaican Gangs................................................................................ 131

Power Structures within the Garrison ...................................................................... 138

A Transnational Perspective on Governance Systems in the Garrison...................... 142

Operational structure of the criminal group.......................................................... 149

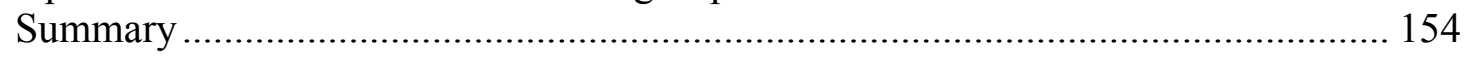

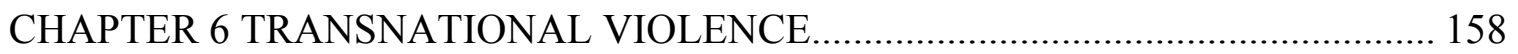

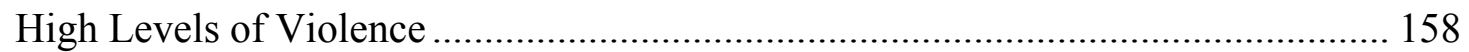

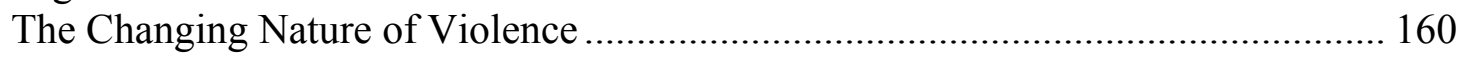

Globalization's affect on the Nature of Violence .................................................... 162 
Exporting Violence- "Brand Jamaica"...................................................................... 169

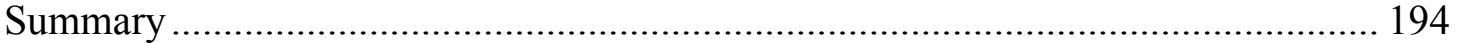

CHAPTER 7 GLOBAL MARKETS, INFORMAL MARKETS AND THE GARRISON

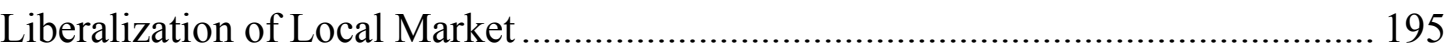

De-legitimized roles of the Jamaican Government.................................................. 196

Community-Based Development, Clientelism, and Liberalized markets.................. 202

Fostering a Culture of Tolerance for Smuggling ………………………............... 217

Factoring in Informal Markets and the Free Market................................................ 220

The Informal Market and Informal actors such as the Jamaican Higgler.................. 222

Organized Nature of Smuggling ……………………………............................. 230

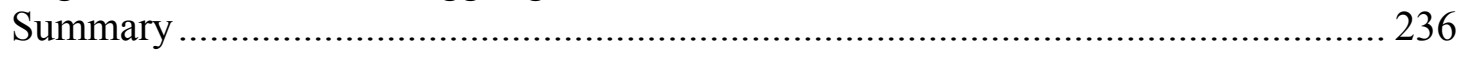

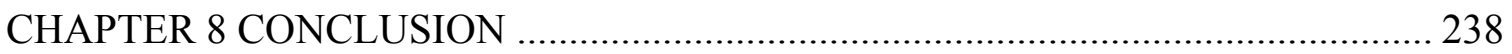

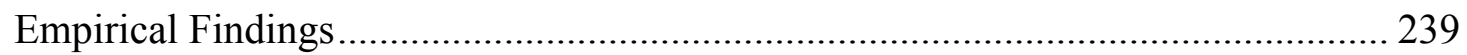

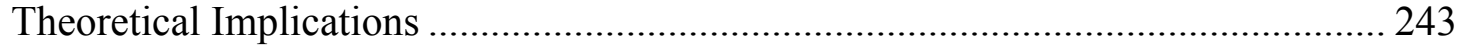

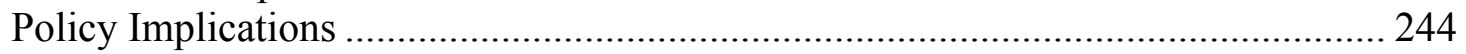

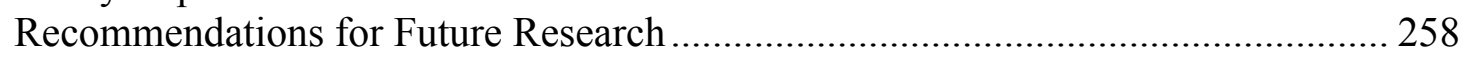

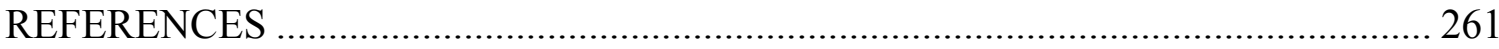

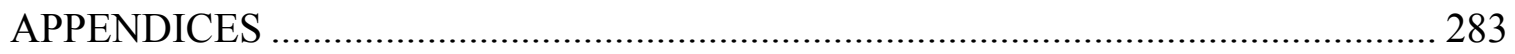

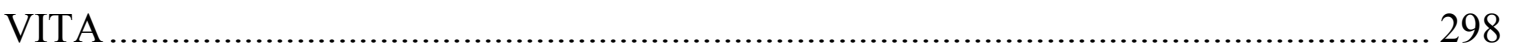




\section{LIST OF TABLES}

TABLE

PAGE

1. Population of Urban/Rural Distribution 2011...................................................... 10

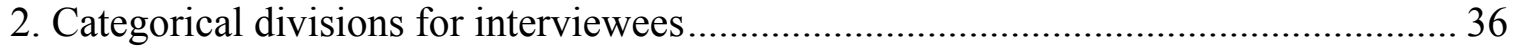

3. Global Corruption Perception Index Data ………………...................................... 166

4. Student Drug Use in Jamaica 2010 ................................................................... 182

5. Firearms and Ammunition Imports to Jamaica by Country of Origin 2006-2011 .... 188

6. Firearms \& Weapons Recovered by Type in Jamaica 2007-2012............................ 190

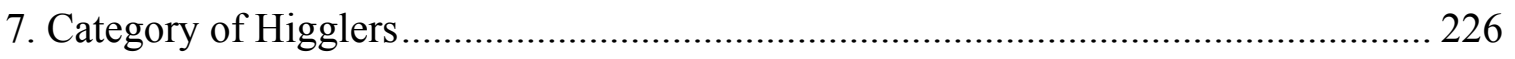




\section{LIST OF FIGURES}

FIGURE

PAGE

1. Major Drug Corridor in the United States ............................................................ 5

2. The Greater Kingston Area (KMA) ................................................................. 9

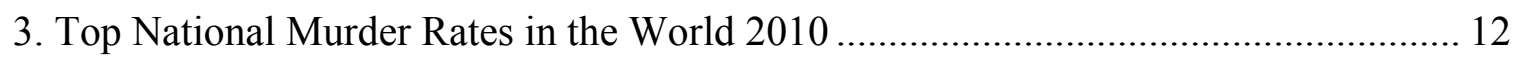

4. Breakdown of Murders in Jamaica by Weapons \& Category..................................... 13

5. Outline of the Kingston Metropolitan Area (KMA) ............................................. 34

6. Kingston Metropolitan Area- Communities \& Population 2011....................107

7. Political Constituencies in KMA............................................112

8. Garrison Consitutencies in KMA.......................................113

9. Garrison Consituencies, Electoral Divisions, \& Communities.......................116

10. Characteristics of Select Garrison Communities in the KMA......................124

11. Map of Garrison Types................................................ 125

12. Map of Garrisons along Voting Divisions................................. 126

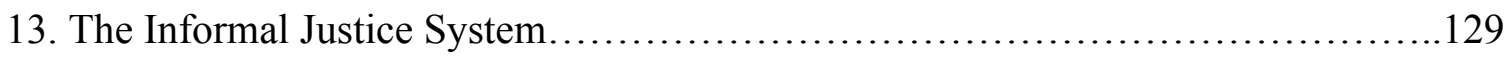

14. Government of Civil Community....................................... 140

15. Uncivil Community Government..................................... 141

16. Transnational Garrison Governance System.................................147

17. Transnational Garrison Operational Network Structure......................... 157

18. Tivoli Gardens Crack Houses........................................ 178

19. Trend in Transfer of Major Arms 2002-2011............................... 187

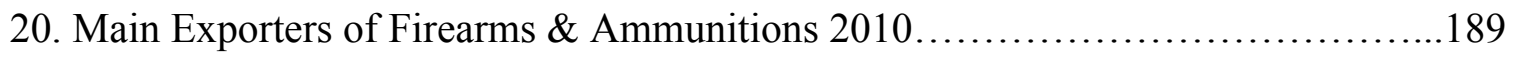

21. Jamaica's Unemployment Rate: January 2004-March $2013 \ldots \ldots \ldots \ldots \ldots \ldots \ldots \ldots . . . \ldots 1$ 
22. Downtown Arcades, Markets, \& Business District...........................234

23. Proximity of Business District 7 Markets to Garrisons...........................235

24. Deepening of Transnationalization in Jamaican Garrisons......................242 


\section{CHAPTER I}

\section{INTRODUCTION}

\section{Overview and Background of the Study}

\section{Within a framework of supply side drug eradication programs.}

Jamaica is nothing if not a place of contradictions. One could accurately describe the Caribbean nation as an island paradise, full of hard-working, friendly people whose contributions to world music, and religion and culture belies their tiny population. At the same time, you could say that Jamaica is one of the most dangerous countries in the Western hemisphere - beset by crushing poverty, a moribund economy and a political system riddled with corruption — and be just as accurate. The fact of the matter is that Jamaica simply cannot be reduced to a twenty-second tourism commercial with smiling natives chopping coconuts as "One Love" plays in the background. Moreover, Jamaica is not the island hellhole full of stoned gunmen and bullet-riddled shantytowns seen in the average direct to DVD gangster flick or episodes of Locked Up Abroad. ${ }^{1}$

As Rodney Walter's quotation underscores, the case of Jamaica documents the key role that transnational criminal organizations play in the ability of a small country to govern itself effectively. It also documents the key role played by transnational relations- the permeability of state borders and the impact of non-state actors - under conditions of heightening globalization. This relationship between transnational non-state actors and

\footnotetext{
${ }^{1}$ Walter, Rodney. "The Abundance of Water: Sizzla Interview." Cool'Eh Magazine (14).
} 
the state has been a hallmark of life in the Caribbean for centuries. Moreover, in the first decades of the $21^{\text {st }}$ century prove critical issues of governance in small states. The study of Jamaica's struggle, therefore, has broader relevance to transnational crime and global government.

Jamaica is the third largest island in the Caribbean with an area of 4,244 sq. miles. Spanning 146 miles from East to West, it is home to 2.69 million people of diverse ethnic origins (Statistical Insitute of Jamaica, 2011). Like other Caribbean islands, Jamaica boasts a year round tropical climate, beautiful beaches, and its proximity to the United States (U.S.). Its geography makes it well placed on one of the world's major shipping and airline routes. However, by sheer location the Caribbean island also find itself in the path of a multi-billion dollar trade in illegal drugs.

The very features that make the location of the region ideal for tourism simultaneously provide international traffickers with easy access to markets with a high demand for illicit drugs, "ample networks of airlines and cruise connections, and a large and mobile volume of tourists" (Ishmael, 1996). In addition, the region's vulnerability to the drug industry has been compounded further by the challenges that Small Island Developing states (SIDS) face in an increasingly interconnected world.

Despite being ranked as an upper middle-income developing country, Jamaica like other Small Island Developing states constantly struggles to alleviate poverty, manage its large debt burden, and curb its high levels of corruption. These struggles have worked to the advantage of traffickers as they demonstrate free reign of inadequately patrolled borders, coastlines, and waters, and even specific locations within these island states (Seelke, Wyler, Beittel, \& Sullivan, 2011, p. 2). Among its fellow Caribbean 
neighbors, Jamaica looms large in the drug industry. It is the Caribbean's largest producer and exporter of cannabis, as well as one of four major drug transit countries in the Caribbean- including Haiti, the Dominican Republic, and the Bahamas- that transship South American cocaine bound for the United States (U.S.), Canadian, and European markets (Sullivan, 2010). Collectively, these four countries including Cuba and Puerto Rico [identified as a minor drug transit point] constitute almost ninety per cent of the Caribbean region's entire landmass. Not only do these countries makeup the larger islands of the region but like Jamaica they are also situated close to North America and are ideally connected to the Yucatan Channel, the Florida Straits, and the Caribbean Sea; making them accessible to global trade and markets and more importantly to illicit global activities.

Within this framework of illicit trade, there has historically been two prized drug transshipment zones; located within both the Latin America and Caribbean regions. Theses are, the Central America-Mexico Corridor, and the Caribbean-South Florida Corridor. Beginning in the mid 1970's through the early 1990's the Caribbean-South Florida Corridor was bestowed the title of the primary corridor for drug trafficking to the U.S. and Europe. ${ }^{2}$ The heydays of Miami's "cocaine wars" and infamous drug cartels headed by charismatic "cocaine cowboys" like Griselda Blanco in the 80s, and Pablo Escobar in the 90s, serve as a clear point of reference for the success of this trade corridor in transporting illegal goods. Playing a critical albeit a relatively smaller role in the Colombia-Miami cocaine industry Jamaican gangs such as the Shower Posse became the

\footnotetext{
${ }^{2}$ See (Fieser, 2010). The Caribbean is still an active corridor, although it is not the primary corridor at this time. A Primary transit country for this region is the Bahamas, which serves as the main transit country for both Jamaican Marijuana and South American cocaine. Also, see (Seelke, Wyler, Beittel, \& Sullivan, 2011).
} 
foot soldiers and enforcers on the ground in Miami, protecting and overseeing local distribution as well as opening up Jamaica as a transshipment point for cocaine and later heroin.

Stemming the tide: What began for small-scale farmers in Jamaica during the 1960s as a viable answer to their economic woes- cannabis as a lucrative export croprapidly became the drug of choice for an emerging group of local entrepreneurial drug traffickers during the 1970s. Since the 1970s, Jamaica has been identified as a major producer and distributor of cannabis. The country continues to be seen in this light today. Jamaica's title of major producer and distributor of cannabis has been fueled further by a growing access to other established illegal markets for cocaine and illegal weapons within the region, as well as by the growing demands for illegal drugs in foreign markets such as the United States. Large-scale eradication programs such as Operation Buccaneer, spearheaded by America's Drug Enforcement Agency (DEA) in 1974 managed to intercept numerous cannabis, cocaine, and gun shipments, as well as destroy massive cannabis production farms. With multiple installments of Operation Buccaneer, lasting through the 1990's the program ultimately constrained the efforts of drug traffickers and producers in Jamaica (Le Pichon, et al., 2011). ${ }^{3}$

\footnotetext{
3 "Jamaica is a case in point. Estimates of the cocaine flow through Jamaica dropped from $11 \%$ of the US supply in 2000 to $2 \%$ in 2005 and $1 \%$ in 2007 . This is reflected in declining seizures in Jamaican and declining arrests and convictions of Jamaican drug traffickers in the United States" (p 53).
} 


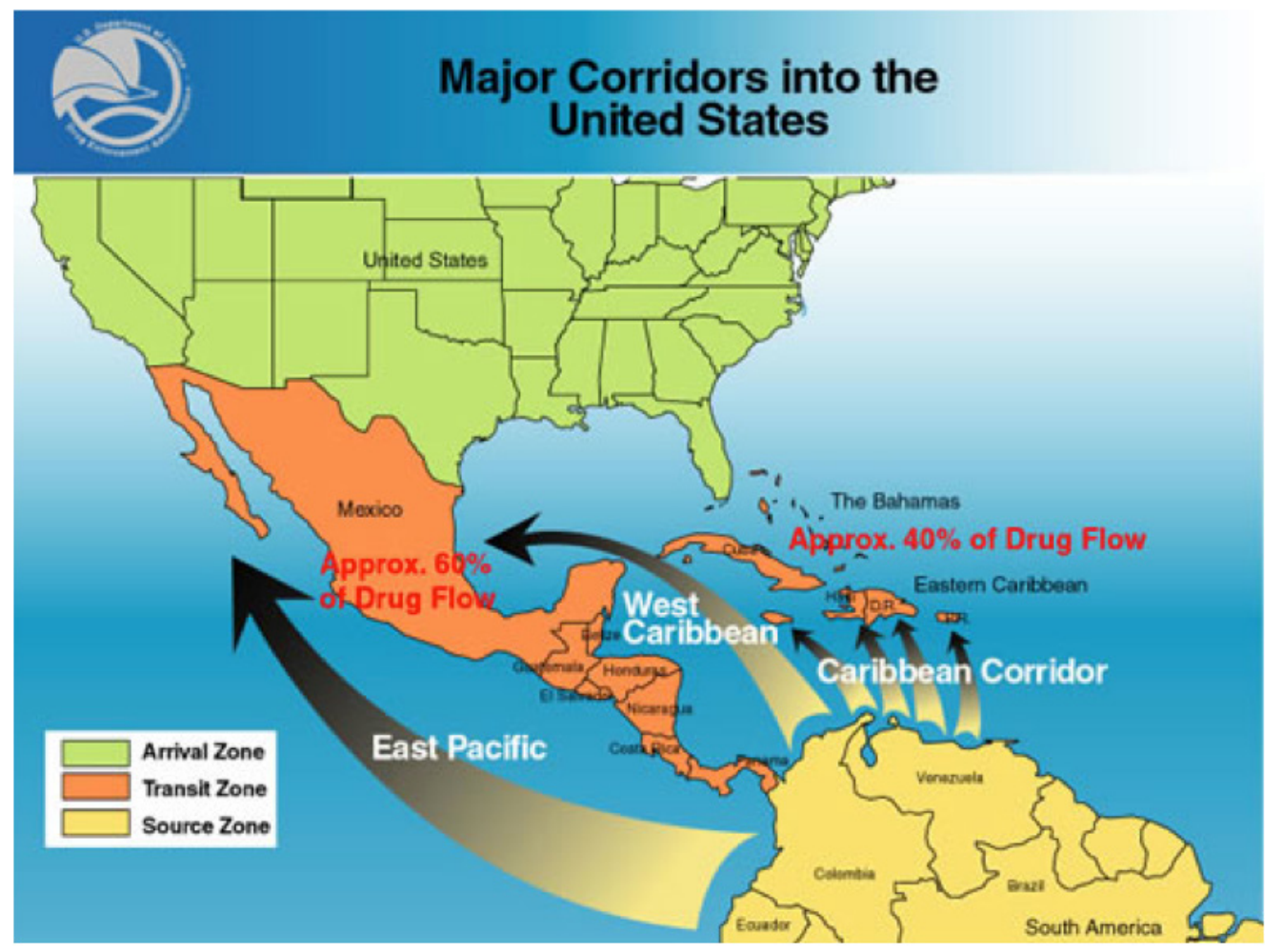

Figure 1. Major Drug Corridor in the United States

Taken from A History of Coast Guard Aviation the Present Era (1995-2008)

http://uscgaviationhistory.aoptero.org/history05.html

Determined to control and to shutdown the rapidly growing and increasingly lucrative drug trade the United States began a series of massive antidrug assistance programs in the mid-1970s geared towards halting the production of illegal products, as well as combatting drug trafficking at the source. With large-scale pressure and attention focused on the Caribbean-South Florida Corridor, the re-routing of illegal goods through the Central America-Mexico corridor began to gain traction in the early 1990s.

Notwithstanding efforts to eradicate the flow of drugs, it failed. The major outcome of the antinarcotic program simply shifted to other major centers of production and distribution in the region. America's successes in its collaborative supply side approach to crippling 
the distribution of drugs to its shores resulted in the creation of other major export corridors. By the 1990s, America's West Coast began to fall prey to the ballooning in shipment and distribution of drugs redirected from the Caribbean through Mexico and Central America.

Once again, heavily focused supply side drug eradication plans were implemented starting with the Andean Counterdrug Initiative launched in 1998, Plan Colombia in 2000, and the Merida Initiative [Plan Mexico] in 2008. Learning from previous experiences in the Caribbean region the United States intensified its efforts to stamp out the drug trade. The massive Andean counterdrug program while focusing on the production and distribution of illegal drugs also attempts to counter the drug trade by focusing on economic and social development (Veillette, 2006; Estefan, 2009). On the one hand, Operation Buccaneer had focused primarily on providing the Jamaican state and its defense forces with the financial resources, the training, and the equipment needed to win the war on drugs (Leckie, 2006). On the other, the Andean counterdrug initiative and the other programs that followed it sought to accentuate and approach the problem with a specific focus on alternative crop development and democratic institution building (Veillette, 2006). The Plan, where applicable, also targeted combating transnational organized crime and money laundering (United States Government Accountability Office, 2010). 
With America's focus on Mexico, the Andean region, and Colombia, as well as the balloon effect ${ }^{4}$ of drug eradication programs, the Caribbean region is projected to become the primary transit corridor for drug trafficking once more (Jessop, 2012). In anticipation of this shift the Obama Administration 2009 has renewed American interest in the Caribbean region by implemented a new successor program to the Mérida Initiative called the Caribbean Basin Security Initiative (CBSI). The successor program is designed specifically for equipment and training to combat drug trafficking and illegal weapons trafficking in the region. Moving beyond seeking the alleviation of drug and gunrunning, the CBSI also includes the protection of borders, the reduction of habitual relapses in crime, the elimination of gangs, and the curbing of terrorism (Holder, 2010).

The United State security approach for the region is tied strongly to its development assistance plan with the developing world. Any Caribbean country that receives funding from any of America's anti drug assistance programs and that does not comply with its requirements will automatically jeopardize their economic and military assistance from the U.S., as well as from multilateral development banks (Grayson, 2010). More importantly, the brief assessment of the supply side drug eradication programs of the United States, in collaboration with developing countries such as Jamaica reveal first that the ballooning effect of illicit markets is tied to the fluidly connected and temporary formed alliances made by non-state actors in the global realm. Second, it highlights how illegal global interactions have strengthened the power base of

\footnotetext{
4 (United Nations Research Institute for Social Development, 1994) “It is likely that one country's success in reducing production will simply be another's problem as traffickers, refiners and intermediaries migrate to places of least resistance and most opportunity, creating a demand for drug crop production. This phenomenon is referred to as the 'balloon effect': what is pushed down in one place simply springs up in another."
} 
non-state actors by allowing them to work around government policy programs intent on stopping them. It is significant that actions of non-state actors in the global drug industry have directly influenced the policymaking process and the strategies taken by the government of these countries as they constantly try to alter their policies for increased effectiveness.

The Problem of Supply From Within: For the Jamaican government, the resurgence of the drug trafficking back into the Caribbean proves especially worrisome when considering how criminal actors hinder the ability of the government to effective govern and protect its citizens within an increasingly interdependent and interconnected world. Despite the fact that Latin America is currently the primary trade corridor, Jamaica has managed to maintain its position as one of the major drug transit countries in the Caribbean region. Further like other countries in Latin American and the Caribbean region, Jamaica has very high crime rates that are tied to violence associated specifically with drug trafficking (Fajnzylber, Lederman, \& Loayza, 1998; United Nations Office on Drugs and Crime; Latin America and the Caribbean Region of the World Bank, 2007; United Nations Office on Drugs and Crime; Latin America and the Caribbean Region of the World Bank, 2007; Shifter, 2007). 


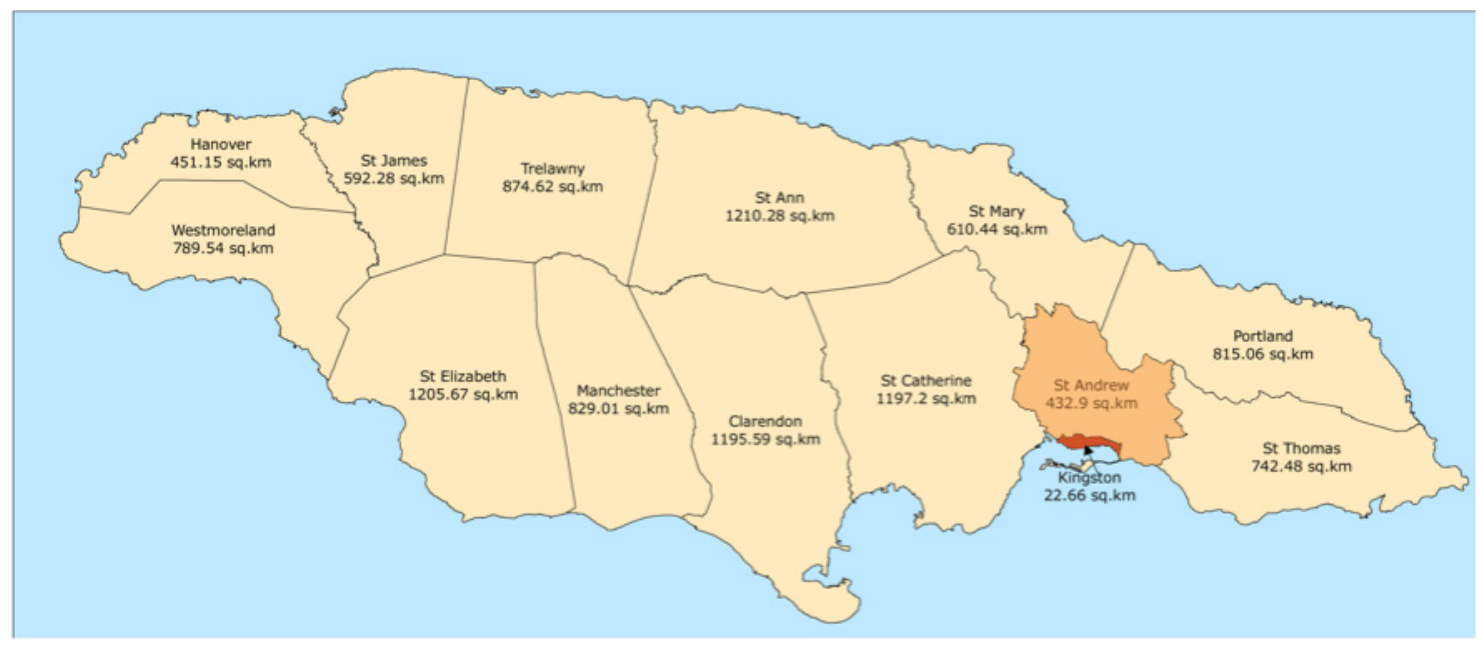

Figure 2. The Greater Kingston Area (KMA)

The Greater Kingston Area [metropolitan Area] spans 175.89 square miles and geographically is comprised of both the parishes of Kingston and St. Andrew under the Kingston and St. Andrew Corporation Act of 1923.

The country's crime rates consistently are ranked as among the highest in the world, "surpassing even war torn areas like Iraq and Afghanistan and ranked with countries with notorious crime problems such as South Africa and Colombia" (Private Sector Organization of Jamaica, 2011). The majority of Jamaica's crime and violence has historically centered on criminal elements that reside within low-income inner city communities within the capital's metropolitan area known as garrisons. 
Table 1 Population of Urban/Rural Distribution 2011

\begin{tabular}{|r|r|r|r|r|}
\hline \multicolumn{2}{|c}{} & \multicolumn{3}{r|}{ Population by Urban/Rural Distribution 2011 } \\
\hline & & Parish & Number & Percentage \\
\hline & & Total & $\mathbf{2 , 6 9 7 , 9 8 3}$ & $\mathbf{1 0 0 . 0}$ \\
\hline & & Urban & $1,453,438$ & 53.9 \\
\hline & & Rural & $1,244,545$ & 46.1 \\
\hline Kingston & & Total & $\mathbf{8 9 , 0 5 7}$ & $\mathbf{1 0 0 . 0}$ \\
\hline & & Urban & 89,057 & 100.0 \\
\hline & & Rural & & $\mathbf{1 0 0 . 0}$ \\
\hline & & Total & $\mathbf{5 7 3 , 3 6 9}$ & 86.5 \\
\hline & & Urban & 495,771 & 13.5 \\
\hline & & Rural & 77,598 & - \\
\hline
\end{tabular}

Note. Adapted from table 1.4 of Census of Population \& Housing-Jamaica (Statistical

Insitute of Jamaica, 2011)

Geographically spanning 175.89 square miles, the Kingston Metropolitan Area (KMA) is comprised of both the parishes of Kingston and Saint Andrew and is home to approximately $25 \%$ of the Jamaican population. Further, the KMA makes up $40 \%$ of the country's $53.9 \%$ urban population and according to Charles \& Beckford (2012), is divided into twelve garrison constituencies each comprising of several garrison communities. ${ }^{5}$ Collectively these garrison constituencies account for $60 \%$ of all identified garrison constituencies in Jamaica. ${ }^{6}$

5 "The garrison constituencies are Western St Andrew, East Central St. Andrew, South Eastern St. Andrew, Eastern Kingston, Central St. Catherine, South Central St. Catherine, Central Clarendon, West Central St. Andrew, Southern St. Andrew, South Western St. Andrew, Central Kingston, and Western Kingston" (pg. 7). * Although Charles identifies 12 garrison constituencies located within the KMA, in actuality three 
Since the 1990's, the crime rate has been tied to violence associated specifically with drug trafficking while before the 1990's violence was identified with the way in which politics in the country has developed. A pattern of communal voting within lowincome communities known as garrison communities in Jamaica has resulted in political tribalism in exchange for spoils along two narrowly distinct political parties (Figueroa, Harriott, \& Satchell, 2008; Sives, 2010). Working within the scope of the state, rather than attempting to overthrow the government garrison communities' have fueled violence via turf wars and staunch political support. The use of violence and the holding of illegal weapons to protect these communities from opposing communities have further reinforced the need and use of high levels of violence (Gray, 2004). A closer look at the country's crime rates also reveals that Jamaica has one of the world's highest murder rates with approximately half of the murders in 2009 identified as gang related (Amnesty International, 2009; Jamaica Has Record Number of Murders in 2009, 2010).

constituencies [Central St Catherine, South Central St. Catherine, Central Clarendon] are located outside of the KMA boundaries.

${ }^{6}$ In addition to the 12 garrison constituencies identified by C.A.D Charles (2012), (Luton, 2010) highlights the creation of three new constituencies across the Island resulting from the 2007 general elections increased the number of political constituencies from 60 to 63. These three new constituencies are East Central St. Catherine, South East St. Catherine, and Central St. James 


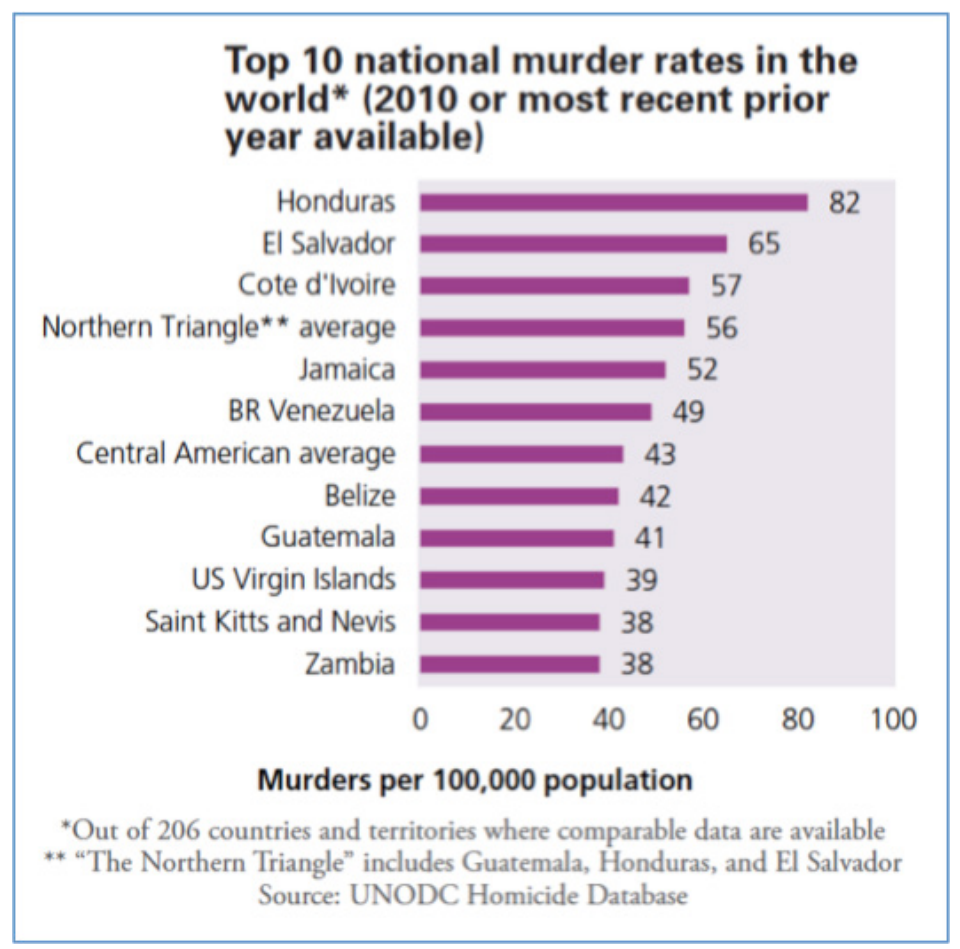

Figure 3. Top National Murder Rates in the World 2010

Taken from (United Nations Office on Drugs and Crime (UNODC), 2012)

Fast-forward to 2011, two years later despite a massive and successful national security force infiltration of one of Jamaica's most notorious garrisons in 2010, the murder rate in 2011 quickly reaffirmed the resilience of Jamaican gangs. Reports in 2011 by the Jamaica Constabulary Forces now reveal that gang related activities accounted for $57 \%$ of the murder rate with $69.9 \%$ of Murders being gun related ( JCF Statistical and Data Management Unit, 2011). 

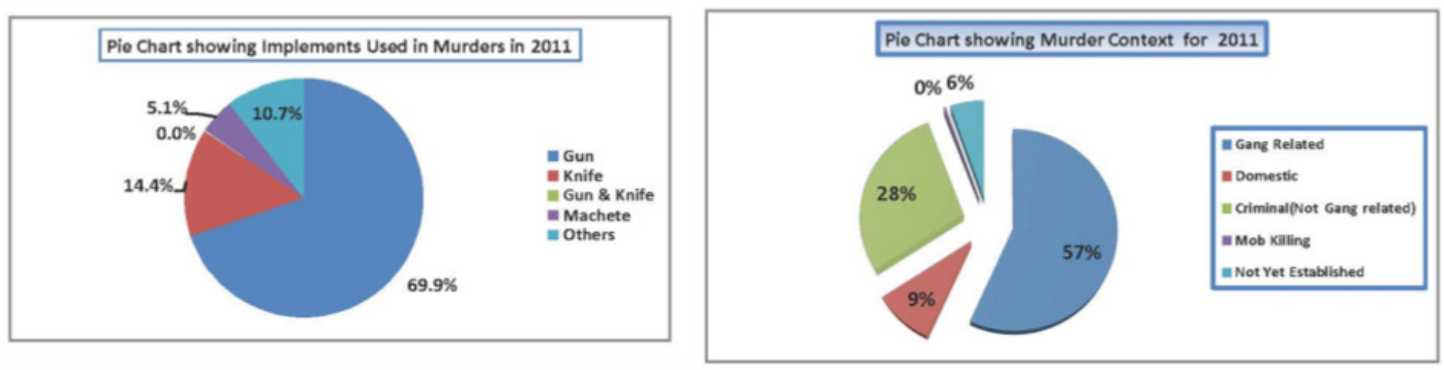

Figure 4. Breakdown of Murders in Jamaica by Weapons \& Category

Taken from ( JCF Statistical and Data Management Unit, 2011)

The formalized role of the garrisons within the political system has allowed for the normalization of high levels of crime by Jamaican citizens. It has also allowed for a growing level of tolerance for accepting some corrupt and criminal acts as the normal way of doing things (Harriott, 2004). Within the garrisons, the older roles of party mobilizers, disrupters of oppositional party events, and of perpetrators of voting fraud, have been complimented by the new roles of providing residents with community policing, punishing criminal offenders within the communities, and with providing protection services for the communities criminal activities.

The influx of crime and violence is attributed to Jamaica's role in drug trafficking. Armed with guns and territory devoid of state control, garrison communities, in addition to their formalized role within the political system, have been able to reduce their dependence on the state by supplementing the role of the state with an involvement in criminal activities. The exportation of cannabis and the trading of cannabis for cocaine, cash, and arms have resulted in a dramatic upsurge of crime. Illegal drugs are sold and are processed in local markets, and distribution channels are maintained through the corruption of officials, law enforcement, and civil servants. There is also the growth of secondary illicit industries, such as the explosion of smaller subsidiary gangs or corner 
gangs, car jacking's, contract killings, extortion, kidnappings, human trafficking, and prostitution (Chatt-A-Box, 2012; United States Department of State, 2011). ${ }^{7}$ More recently, criminal activity in Jamaica has extended to financial fraud including ponzi schemes and lottery fraud indicating a turn to more clearly identified transnational forms of criminal activities. The need for increased protection of the legal and criminal property of the garrison leaders has also resulted in the increased use of firearms and force and the laundering of drug money that has led to the fusion of legitimate and criminal economic activities and industries (United States Department of State, 2011).

\section{Identifying the Garrison}

The drastically changing social, economic, and political conditions of the state constantly affect the survival, growth, development, and response of disenfranchised segments of the population. As is commonly found in the developing world, these segments of society have developed and established permanent communities or slums whether legally or illegally by occupying vacant land owned by either the state or a private entity (Figueroa \& Sives, 2002). These area slums are characterized by low education, limited access to education, poor nutrition, high infant mortality rates, and low life expectancy. ${ }^{8}$

\footnotetext{
${ }^{7}$ While there is little hard evidence in terms of statistics to highlight these trends, it is common knowledge in Jamaica that for the right price members within corner gangs in garrison areas are willing to carry out killings. This is also the case for kidnappings, and human trafficking. Jamaica currently is ranked in tier two in the world in the Trafficking in Persons Report, and is listed among the main trans-shipment ports for the trade.

${ }^{8}$ Most importantly, in addition to these socio-economic characteristics these communities possess a distinct concept of identity, security, and legal and political rights that are different from that of the wider society and from that of the state. These identities are continuously reinforced and modified over time in response to socio-economic crisis, and entail political implications at both the domestic and international level.
} 
Further, in the case of Jamaica these communities over time have constructed and reinforced territorially distinct political divisions called garrisons. More precisely, in an attempt to manage the growing segment of the population and to assuage their high levels of dependence the Jamaican government has reinforced clientelistic practices that tie specific garrison communities to either of the two main political parties. ${ }^{9}$ As Carl Stone points out in his research on democracy and clientelism, "a garrison as the name suggests is a veritable fortress where the dominant party and/or its local agents/supporters are able to exercise control over all significant political, economic, and community related social activities" (as cited in Figueroa, 1985, p. 83). Best understood as a territorially defined politicized segment of society a garrison consists of the hard to employ, the long-term unemployed, and the working poor.

Eventually, the timing and duration of political spoils diminish and drug trafficking became a practical means of supplementing the vacuum that resulted from deficient political spoils. In some cases, drug trafficking became a more powerful means; it provided criminal entities with a viable way to provide revenue for political campaigning. Naturally, there was a gradual shift in power with the government losing advantage and the garrison gaining. Garrison leaders were able to create their own revenue and provide directly for the community; now they are able to provide the state with not just votes but also with political funding and the resource needed to keep the garrisons empowered - drugs and guns.

\footnotetext{
${ }^{9}$ The Jamaica Labour Party (JLP) and the People's National Party (PNP)
} 
Today, garrisons are comprised of the politically displaced, the poor, as well as legal and criminal entities. The removal of the state from these areas has provided criminal entities not only with a space in which to operate, but it has also fostered an increasing demand for illegal goods and activities. Developing competing governance structures to the local government, garrisons play an increasing role in determining the role of political behavior and the legitimacy of the state

\section{Analysis of Existing Garrison Literature}

Political science research on Jamaica has primarily focused on three main themes. First, there is a focus on both the redesigning and strengthening of the effectiveness of social and political institutions (Munroe 1999, 2000; Ryan 1999). Second, there is a focus on revealing how alienated segments of society have constructed "exilic social spaces" (Gray, 2003) in opposition to Jamaican state ideology (Gray, 2004; Meeks, 2000; 2007; Bogues, 2002; Thomas, 2004). Aligning with this current study, a third and overlapping theme centers on notions of governance and the complex relations that exist between the Jamaican state and garrisons.

A more narrowly focused analysis of garrisons can be divided further into three main categories. The first and most popular explanations of the garrison have focused on the notion of garrisons as partisan political centers of violence, and they revolve around patterns of voting, and the formation of political communal identities. Second, other explanations focused on various political-cultural aspects of the garrison. These illustrate the growth and development of the garrisons and the relationship between the formations of political identity in relation to other communal and individual identities within the state. The focus here is on the garrison identity as a product of the culture of electoral 
politics. It is within this context of the garrison as a normal part of the state structure that the third set of discussions of the garrisons as centers of criminal activities, crime and electoral manipulation take place.

Partisan Political Centers of Violence: Figueroa et al. (2008) examine several factors that they believe have led to high levels of violence in Jamaican inner-city communities. All of which relate to the way in which politics in the country has developed. More specifically, like Sives (2010), they focus on how Jamaica's consistent and long standing communal pattern of voting has given it a uniqueness that is not rivaled in the surrounding English speaking Caribbean, nor among countries with unbroken systems of governments, nor even within countries with no stark divisions in its ethnic, religious, or social make-up. They assert:

The only basis for the communal identities that drive these voting patterns are traditions of political affiliation as the ideological differences between the parties are narrow, hence the nomenclature that is popularly used in Jamaica: political tribalism (p. 102).

Similarly, Gray (2004) points out that with few differences between individuals living within the urban areas of Kingston, cultural and political identities were fused together by party politics. The new mix of identities allowed these urban communities to act as culturally distinct communities fighting each other to defend what became perceived as divergent yet inviolable and sacred principles. It is within this framework, that Figueroa et al. (2008) discuss the significance of garrison politics on community organization, crime, violence, and corruption as they relate to inner-city communities and to the establishment and development of the garrison. 
Deviating from traditional views that politically violent actions or actors are primarily interested in overthrowing the state garrison interactions illustrates how the state and its political leadership have sought to secure its power base by bringing to fruition its desire to convert all communities within its constituencies into garrisons. "In that sense, construction and maintenance of the garrison is a product of Jamaica's electoral politics" (Sives, 2010; xiii).

For Gray (2004), political leadership is reinforced by a Jamaican state that is constantly shifting its definition of what constitutes the law, morality, and crime. "What is regarded by the state as 'criminal, 'illegal', and 'morally right' gets redefined as acceptable or unacceptable depending on the exigencies faced by rival parties and their competing interests" (Gray, 2004; 7). The shifting definition has allowed for the control of turf to play an important role in the garrison process, as well as allowed for the justification of the use of violence and the holding of illegal weapons to protect these communities from opposing communities.

As Figueroa et al. (2008) point out for anyone, "to take a stand against the illegal activities of the so-called 'community defenders' would be to act against the community" (p. 107) and to take a stand against its very existence. Hence, Headley (1996) indicates that more sophisticated weaponry such as guns where brought into the garrison communities by "some of the islands leading politicians who needed 'safe seats"” (p. 32) in order to ensure predictable voting patterns in their favor. These guns were tools of intimidation and protection. 
Political-Cultural Aspects: the Garrison Identity: Interested in explaining how garrison communities originate and more importantly grow scholars such as Figueroa and Sives (2002) focus on the 'garrison process'. While they embrace Stone's (1983) definition of garrisons as intentionally created political spaces that fall under the auspices of the state, the authors' compliment this understanding of the garrison by focusing specifically on the high degree of political exclusivity that these communities provide within their borders.

Figueroa and Sives (2002) define the garrisons as communities in which, “... any individual/group that seeks to oppose, raise opposition to or organize against the locally dominant party would be in physical danger, thus making continued residence in the area extremely difficult, if not impossible" (p.85). As such, they are concerned with identifying the various factors that contribute to the politicalization of several urban communities in the Jamaican state. These two authors assert that garrisons have become synonymous with the process of electoral manipulation, specifically, homogenous voting and the use of gun violence. They contend that garrison members have confidently been able to alter voting registrations and adjust the number of oppositional votes that take place within their communities during elections with little to no fear of any repercussions. The altering of votes allows for homogenous voting, "the process whereby one party receives all the votes in a box, or all but ten or less votes" (Figueroa, 1985; 71-106).

Further, Figueroa and Sives (2002) stress that the political culture of the urban poor in the Jamaican society is a result of the patterned distribution of income and wealth in the society, how this distribution is tied to race and the social distance between the poor, and the rich. In this way, the political culture of Jamaica accepts the barter of votes 
by communities in exchange for material resources and recognizes political mobilization as a community process.

According to Gray (2004), the Jamaican state is best understood as a hodge-podge of paternal, authoritarian, and democratic identities. The assortment of identities drives the Jamaican state to forge a parasitic relationship with the urban poor allowing it to simultaneously feed on and assimilate into the urban poor's cultural structures. Within the context of multiple identities the urban poor' response to the state has in turn been a complex relationship involving "dependencies, bargaining, and trade-offs between protagonists" (p. 12). The multiple identities of the state were reinforced by the war for power and political spoils that developed during the early anti-colonial politics of the nationalist movement in the early 1950's.

Sives (2010) demonstrates that while material exchange of goods is a very important feature of clientelistic relationships between the urban poor and Jamaican political parties, it is not the only feature of clientelistic relationships. Rather scholars can identify a form of clientelism that incorporates the formation of political identities. For garrison members locked into a particular party affiliation what may have once begun as a strategic calculation of interests overtime has developed into an intense and unconditional partisan loyalty (p. xxi). If this were not the case then we would see the urban poor utilizing their power during elections to successfully wield power over the parties. "It is the protection of this partisan identity which is one of the factors explaining the violence [in the Jamaica society]" (p. xxiv). 
Expanding on the discussion of the impact of political culture on community identity formation and the use of violence, Figueroa alongside Harriott and Satchell (2008) argue that political organization has at times fed on and fostered the presence of strong community identities that at times overlap with political identities. First, political organization reinforces Gray's (2004) notion of the complex and contradictory relationship that exists between the state and the urban poor. Second, the overlapping of community and political identities indicates that the urban poor possess a collective identity that relates to larger entities such as the state, as well as multiple layers of communal identities that tie them to specific communities, and often times to even smaller groupings identified within the community.

Centers of Illicit Activity: For Harriott (2004) what seems most important is the relationship that exists between politics and crime. He asserts, "political relationships and methodologies of political mobilization, operate as root causes of crime, not just as facilitators of crime" (Harriott, 2004; xii). Here he sees the political methodology of the Jamaican political parties as completely enmeshed in the rise of large-scale and institutionalized criminal activity with criminal individuals and communities- where political methodology refers to the "systematic use of violence to achieve electoral objectives and clientelistic mobilization" (Harriott, 2008, p. 9). What distinguished these political parties from simply being explained as organized criminal organizations is that while they actively engage in criminal activity they do not exist for criminal engagement. 
Rather, [they] represent a distinctive case of elite-mass criminality in that [they] bring together the powerful and the relatively powerless. As well as, people from different locations in the social hierarchy but with similar motivations, in organized criminality, open and on a mass scale (Harriott, 2004; xi).

Using garrison communities as an example, Harriott focuses on the normalization of high level of crime by Jamaican citizens and on the growing levels of tolerance for some corrupt and criminal acts as the normal way of doing things.

Therefore, for Harriott the normalization of crime has allowed street criminals and members of organized crime groups who reside within the garrisons to develop new roles in relation to the citizens of the community, as well as in relation to the state. The older roles of party mobilizers, disrupters of oppositional party events, and of perpetrators of voting fraud, have been complimented by the new roles of providing residents with community policing, punishing criminal offenders within the communities, and with providing protection services for the communities criminal activities.

\section{Identifying the Garrison from a transnational scale.}

It is hard to believe that just a handful of criminal elements residing within such small territorial spaces inside Jamaica's borders could essentially be responsible for the country's consistently high crime rates, involvement in the drug industry, and negative image in the global realm. Dense forests and dangerous mountain terrains neither surround garrison communities nor are they characterized by permanent impenetrable walls. Yet, although located mainly in squatter zones and government housed inner city areas, these communities still manage to create and maintain well protected territories devoid of state control and that are conducive to criminal activity. 
Garrisons have become institutional power structures (Figuera, Harriott, and Satchell, 2008; Sives, 2010; Gray, 2004; Headley, 1996; Stone, 1983; Figuera and Sives, 2002). What is less clear, and the basis for my dissertation, is how these criminal entities have been able to strengthen their power bases in relation to the Jamaican state- offsetting the state's monopoly on power. In the context of this research, garrisons are defined as primarily politicized and territorially defined communities that are comprised of gangs and impoverished individuals.

What is missing from previous research on garrisons is a study of the garrison's transnational nature. Applying Nye and Keohane's (1971) understanding of transnational relations as, "contacts, coalitions, and interactions across state boundaries that are not controlled by [the state]" (p. 331) to an analysis of Jamaican garrisons, the dissertation asserts that the Jamaican case reveals that the interactions between garrisons and the Jamaican state have become more transnational over time.

Shaped by territorial constraints, the nature of domestic politics, and advances in science and technology, criminal entities within garrison communities--to varying degrees--have played a direct role in shaping the behavior and policy goals of the Jamaican state. As a result, the relative power between the garrison and the state is offset. The transnational interactions between the Jamaican state and garrisons have consistently influenced the evolution/creation of new issues and processes. These over time have shifted the state's response. Ongoing events illustrate how state-garrison interactions have framed policy responses to criminal gangs, drugs, and arms eradication campaigns and programs. 
First, the existing literature assumes that the globalizing forces driving the evolution of criminal groups in Jamaica has removed or significantly weakened the political identity of the criminal elements within the garrisons. Previous scholarship [introduced above] sees criminal groups and networks as primarily forged along economic relationships facilitated by globalization. That once overt and prominent political party identity that was authenticated within garrisons in the 1940s and consolidated in the 1960 s has more recently been reduced to political relationships that are little more than leverage points for criminal activities to take place. However, although the most important elements of transnational entities are their social and economic characteristics, this does not mean that the transnational activities carried out are without significant political consequences. Inadequate attention has been focused on how criminal elements utilize transnational activities to alter the underlying interests of the Jamaican state. Consequently, policy choices have been modified in light of an assessment of the cost of the state action. The continuing power of the garrison to affect important Jamaica public decision/state decision-making means that the garrison still maintains significant political identity.

The earlier formalized role of the garrison within the political system during the 1960s, has also managed to preserve, yet redirect some elements of the political identity of the garrison through what Nye and Keohane (1971) refer to as, "societal interdependence." While the primary goals of garrison leaders and the Jamaican state may change the established interdependence between the Jamaican state and garrisons consistently allows for shifts in the nature of the interdependence, over time. The persistent dependence on the state allows garrisons to retain and to redefine aspects of its 
political identity. In the 1960 s, political enforcers in the garrison were responsible for ensuring votes, organizing garrison constituencies, distributing political favors, and enforcing party loyalty (Moser \& Holland, 1997) in exchange for first dibs on jobs and housing from the state. By the 1980 s, the political enforcer is replaced by the criminal don. The enforcer became a chameleon trading his prominent political presence in the political party system for the shadows of the garrison. Finding a more lucrative and consistent means of providing for his garrison via the drug industry the don became less dependent on political parties for seasonal jobs and the social development of the community. 'Societal interdependence' shifted to garrisons dependent on the state for access to arms and corruptible elements of the state. In return, the state did not always override the interests of the garrisons in return for community votes, party loyalty, and because garrisons were now providing social services to communities that, a newly transformed new neoliberal state could no longer manage. Despite shifting interests, "societal interdependence" ensures the continued relevance of the political identity of the garrison, and indicates that in order to function effectively garrisons must strike bargains with the Jamaican state.

Second, the works of scholars such as Harriott (2008) and Gunst (2003) while emphasizing the expansion of transnational criminal activity on economic expansion of Jamaican gangs in the United States, Britain, and Canada, maintain an implicit understanding that these entities only become transnational once they leave their country of origin. The current study illustrates how Jamaica's garrisons directly participate in transnational criminal activities without leaving their neighborhoods, or without maintaining branches outside of Jamaica. The study also illustrates how institutionalized 
transnational activities permeate Jamaica's boundaries to such a degree that local criminal groups become a seamless part of globalization. Transnational activities raise huge difficulties for governance at the local level. Central to the current study is the idea that purely domestic entities can participate in transnational interactions. Criminal entities residing within garrison communities can and do carry out transnational activities without leaving their localities, or without maintaining branches outside of Jamaica. In order for garrison communities to conduct 'transnational' interactions across state boundaries they must assume a geocentric attitude- think global, act local. ${ }^{10}$ Criminal entities residing within garrisons have managed to increase their relative power vis a vis the Jamaican state, by moving beyond geographical barriers and focusing criminal activities and behavior on the basis of the success of international criminal activities. Analysis in the dissertation further shows that there has been a general shift from aspirations of a top down decision-making and centralized management style among the criminal entities in the garrisons, towards varying degrees of decentralized and transnational management and decision-making.

More importantly, a shift in perspective firmly recognizes that although garrisons take on a geocentric attitude and apply geocentric approaches they do not become fully geocentric entities. That is, little data indicate that any specific garrison within Jamaica

\footnotetext{
${ }^{10}$ (Nye \& Keohane, 1971)“These organizations are transnational by our definition, but they are not 'geocentric.' An organization becomes geocentric only when the composition of its leadership and its pattern of behavior indicate that it has lost all special ties to one or two particular states. Intergovernmental organizations often devote considerable effort to assuring that they will be geocentric in fact as well as in name: One need only note the continuing attempts by less developed states in the United Nations to assure 'equitable' geographical distribution of positions in the secretariat. Transnational organizations, by contrast, are rarely established as such but usually evolve gradually from national organizations. Furthermore, they frequently do not have autonomous constituent units-such as the states in intergovernmental organizations-to insist on geocentricity. Thus, transnational organizations tend to become geocentric gradually and quite frequently move in that direction only after pressure has been brought from outside, particularly by host governments." (Introduction)
} 
has severed or lost all ties to the Jamaican state. While garrisons may take on varying degrees of geocentric patterns of behavior- simultaneously using global interactions of communication, transportation finance and travel to conduct business- there is no example of a garrison that has bestowed leadership on any individual who is not first a Jamaican and second, someone who is does not reside within Jamaica.

By examining the relationship that exists between the Jamaican state and garrison communities, the dissertation asserts that a case study of Jamaica allows for an exploration of how:

1) Governments of developing countries simultaneously faced with global, international and local pressures have at times institutionalized criminal power structures by trading votes for favors within criminal communities.

2) Second, that criminal entities through heightened conditions of globalization have been able to challenge the legitimacy of the state in key communities over time:

a) By taking advantage of clientelistic relationships with the state,

b) Using violence and corruption to restrict community access and to maintain spaces of illegal activity,

c) Wielding power by utilizing access to global markets to garner community loyalty and control and, by

d) Forming organizational structures within localities that simultaneously work with [community organizations] and against the state [gangs].

Further, through a case study on Jamaica, the current study illustrates the proclivity of globalization to blur the lines between the domestic and the foreign affairs of a country. The Jamaican state and its institutions are shaped not just by political culture but also by 
global forces. While political culture has helped to shape the creation of the garrison, conditions of globalization have allowed transnational criminal actors to enhance the capacity of the garrison beyond the sovereignty of the Jamaican state - thereby strengthening the power of criminal groups vis-a-vis the state. The present research highlights the permeability of state borders and the impact of local non-state actors under conditions of heightened globalization. The research also indicates that criminal basednetwork groupings play a key role in the ability of a Small Island Developing State such as Jamaica to govern itself effectively. Finally, the dissertation asserts that not only have garrisons become more transnational, but also that the case of Jamaica reveals a deepening of transnationalization within and across garrisons. This process is expressed in terms of the changing nature of the organizational and power structures of criminal groups, the increasing use of violence, and the growing determination of these groups to maximize profits; orchestrated through heightened transactional interactions as figure 24 on page 242 illustrates.

\section{Thesis Organization}

Chapter 2 begins with a look at the methodology of the study. It examines the pros and cons of utilizing a qualitative research design, as well as the advantages of taking a case study approach by focusing specifically on the case of Jamaica and the urban landscape of the garrison. Chapter 3 lays out the theoretical framework in which the study takes place. It points out that globalization is concerned with the spread of new forms of non-territorial activities and with how distinct events and forces influence activities that occur at the local, national, regional, and global levels. Transnationalization on the other hand, is concerned with activities that are anchored to specific localities and 
that by non-state actors interested in shaping outcomes, initiate and sustain. Chapter 4 becomes with the story of how and why garrisons were institutionalized through the political system emerging from street gangs in the 1940s and transforming into newly politicized urban slums in the early 1960's through the early 1980's.

This then leads to chapter 5, which indicates that criminal groups within the garrison have utilized the forces of globalization to organize and structure themselves in more effective ways. Rather than identifying these criminal non-state actors as organizations, they are best understood as network based groupings with flat hierarchical structures. Ultimately, the chapter indicates that a static perception of the garrison clouds its transnational nature. Chapter 6 entails a discussion of how the success of Jamaican gangs in criminal activities has hinged on its ability to convert violence into a product that is focused locally, yet reflects the expectations, standards, and norms of the global market and product to which it is tied. In addition to conceptualizing transnational violence as a commodity, the chapter also identifies it as a commodity packaged alongside other commodities that are violent in nature. Chapter 7 looks at how liberalization has allowed for the deregulation of markets, creating avenues for criminal networks to form illegal markets that run alongside legal channels of distribution. The chapter points out, that liberalization of Jamaican market has not only allowed criminal networks in Jamaica to take part in illegal industries at a low comparative risk, but it also allowed them the resources to garner wide spread control of garrison communities.

The study concludes with a synthesis of the main empirical findings, and a reexamination of the significance of examining the Jamaican garrisons from a transnational perspective. Further, it reviews the recent extradition of Christopher 
'Dudus' Coke, and explores the pattern of illicit transnational interactions that also takes place in other locations such as Brazil, South Africa, and Russia. Finally, the study ends with a look at the direction that future research on this topic might take. 


\section{CHAPTER 2}

\section{METHODOLOGY}

\section{A Note on the Research Design}

How have criminal non-state actors located in garrison communities managed to successfully leverage power against the Jamaican state? This is the central question framing the research design presented in this chapter. A qualitative research design has proven most suited for the current study allowing the researcher to utilize a wide range of research methods--observation, open-ended interviews, document data, audio-visual data, and text and image analysis--in order to identify the mechanisms by which non-state actors have been able to alter their power relation with the Jamaican state. As Flick (2007) points out, "qualitative research is intended to approach the world 'out there' and to understand, describe and sometimes explain special phenomena 'from the inside' in a number of ways" (p. ix). As such, it offers an analysis of the experiences of individuals and groups, their interactions, and their communications that are "essentially descriptive and inferential in character" (Gillham, 2000, p. 9). More specifically, it provides a localized and contextually rich description and interpretation of the ways in which nonstate actors perform transnational activities. A qualitative research design is most suitable for research where a researcher is:

a) Seeking to develop theories or hypotheses, b) seeking an understanding of the subjective meaning of behaviors or social processes, c) the concepts of interest are not easily reduced to categories or numbers, and d) there is relatively little that is known about the subject of study (York, 1998, p. 23) 
According to Woodside (2010), "a case study is an empirical inquiry that investigates a contemporary phenomenon within its real life context, especially when the boundaries between phenomenon and context are not clearly evident" (p. 1). Within the qualitative research design, the case study was selected as the most optimal strategy of inquiry primarily because of the nature of questions that frame this research. The current study on the transnational nature of garrisons is broadly concerned with exploratory questions of 'how' and 'why' non-state actors are able to act in a particular way. Such questions, "deal with operational links needing to be traced over time, rather than mere frequencies or incidence" (Yin, 2009, p. 9) and represents the ways in which survey research is analyzed.

A case study approach is also distinct from other strategies of inquiry such as experiments and historical research based on the researcher's inability to control behavioral events and given the contemporary nature of the research (Creswell, 2009). Not only does a case study strategy allow for the application of multiple research methods, but it also allows for the study of contemporary events, such as a study of garrisons, using participant observation and interviews. Where a historical approach focuses on the 'how' and 'why' of the past, a case study is better able to examine the present day-to-day activities and interactions that influence behavior, as well as gather first hand retrospection on the past. In addition, while experimental research, like a case study, also seeks to show causalities by determining how a specific treatment influences an outcome, this approach is limited in its ability to account for sudden unexpected changes in an uncontrolled environment. 
A case study approach is best suited for the complexity of embedded interactions that take place within the real world, that is, within the messy realm of reality (Gillham, 2000). Compared to experiments, survey, archival research, and historical analysis the case study is the ideal strategy of inquiry that is both practical and is ethically justifiable for a study of the transnationalization of the Jamaican garrison. The approach not only allows the researcher to explore complexities that arise during the conducting of research, but it also allows the researcher to view the case from the perspective of those involved. Ultimately, the process of transnationalization is a fluid and diverse process that occurs at multiple levels of interaction. Similarly, the changing structure of criminal nonstate actors residing within Jamaican garrisons is a sensitive issue concerned with illegal behaviors and actions. As Gillham (2000) asserts, “"theory' is commonly assumed to be something there and established. However, theory is something researchers create. It may be that they only modify existing theory or it may be that they start from scratch, but theory is not primary; evidence is primary" (p. 12). Based on the information obtained from the literature review on garrisons, as well as from secondary research the study further employs a multiple case study design. The design has allowed the study to compare the behavioral norms and lived experiences of multiple individuals and groups that reside within more than one garrison community. 


\section{Case Settings and Participants}

The setting: The study focuses on Jamaica's urban landscape. More specifically, the case study design is conducted primarily within the Kingston Metropolitan Area, home to several garrison communities. Urban communities that are experiencing what Figueroa and Sives (2002) refers to as the "garrison process"-- the process whereby inner city urban communities have become increasingly characterized by a political identity tied to homogenous voting, and to political party patronage.

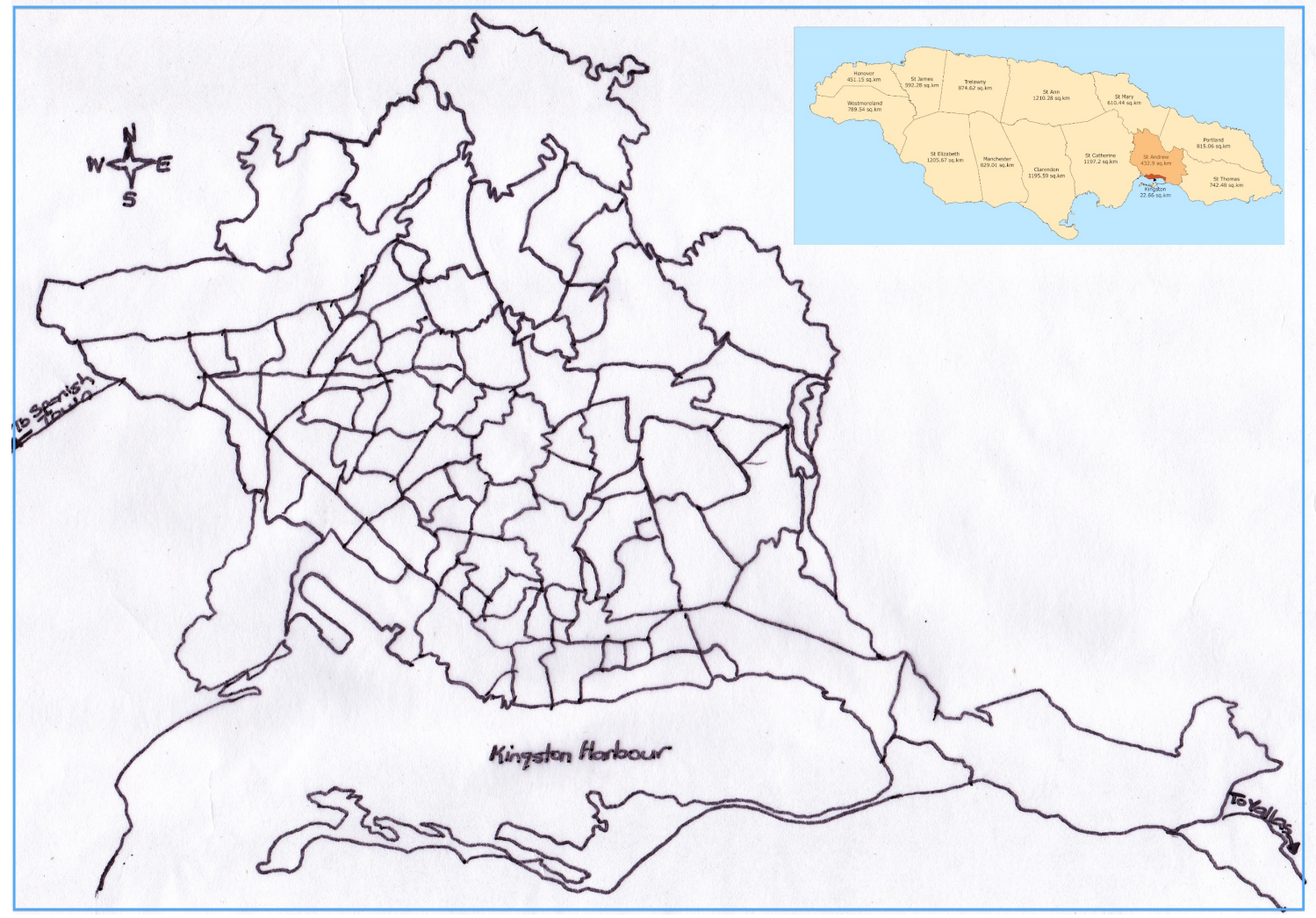

Figure 5 Outline of the Kingston Metropolitan Area (KMA) 
Research Participants: The study utilizes data collected from participants a) residing within a wide cross section of garrisons within the KMA area, as well as b) participants residing outside of garrison communities. Widening the research base allows the study to make possible analytical generalizations for a greater understanding of the complexities of the process of transnationalization. In addition, by investigating the behavior and actions of a wider cross section of participants, the study is better able to examine the influence that the actions of criminal non-state actors within garrisons have on the larger Jamaican society.

Participants include, people who reside within the garrison; academics, who specialize in the analysis of electoral politics, and on political, social, and economic power dynamics prevalent in Jamaica. Participant selection also pertains to political representatives and political officials who have represented/currently represent garrison constituencies and communities of interest to the study. As well as, to key figures of civil society groups and organizations such as the clergy, resident committees, and community outreach groups, with a vested interest in community renewal, protection of rights, and community unification. Members of the media who report on garrisons politics and members of the police force were also included.

In addition to collecting data from a wide spectrum of respondents, the research was informed by several participants, whose personal, professional, and social roles often intersected-allowing for a more complex perspective of the research themes. For example, it was normal to come across a respondent who resided within a garrison community, or who frequently interacted with persons from a garrison community, while they occasionally reported on the shortfalls of the subject of garrisons in public mediums 
such as the local newspaper. Yet, they were also professionally associated with political organizations that collectively voiced a different agenda or view.

Table 2 Categorical divisions for interviewees

\begin{tabular}{ll}
\hline Sample of Interviewees & $\begin{array}{l}\text { Unemployed or self employee people, } \\
\text { taxi drivers, political } \\
\text { activists/followers, student, vendors, } \\
\text { hustlers, farmers, shopkeepers, } \\
\text { gangster }\end{array}$ \\
\hline $\begin{array}{l}\text { Church leaders/members, human rights } \\
\text { activists, youth group members }\end{array}$ \\
\hline Community/Civil Groups & $\begin{array}{l}\text { Lawyers, public relations executives, } \\
\text { graphic artists, urban planners, } \\
\text { teachers/university lecturers, police } \\
\text { officers, security guards }\end{array}$ \\
\hline Professionals (Employed Sector) & $\begin{array}{l}\text { Cabinet ministers (ministers of justice), } \\
\text { members of parliament, heads of } \\
\text { political party affiliate groups }\end{array}$ \\
\hline Media Practitioners & $\begin{array}{l}\text { News editors, reporters, talk-show } \\
\text { hosts (radio and television), } \\
\text { commentators, radio disc jockeys and } \\
\text { announcers (male and female, older } \\
\text { and younger) }\end{array}$ \\
\hline Note: Categorical divisions for interviewees taken from (Johnson H. , Challenges to Civil \\
Society: Popular Protest \& Governance in Jamaica, 2011) \\
Research Instruments \\
Preliminary research obtained from the literature review on garrisons helped to \\
and \\
frame the primary research questions used in the present study. In addition, a review of \\
the garrison literature also played a role in selecting the right mix of research instruments \\
suited for a consistent process of data collection. From preliminary research, the study \\
\end{tabular}


supplemented further, with secondary research derived from a wide range of text, audio, and visuals not limited to geo-spatial maps, newspaper articles, radio, television interviews, discussion programs, as well as formal and statistical reports as they pertain to topic of garrisons.

Interviews: The in-depth interview and focus group discussions are formulated around questions that set out to explore, how criminal non-state actors have managed to leverage power vis-a-vis the Jamaican state. Despite territorial constraints, how have these entities been able to exploit their political interactions in order to preserve and strengthen their social and economic activities within the community and, how have they managed to forge economic networks beyond the boundary of the Jamaican state? Equally important, why have these non-state actors, for the most part, been successful?

When conducting in-depth interviews, the overarching themes allowed the interviewer to focus the specific interview questions posed to all respondents groups [except those within the category of 'informal' people] around four main thematic aims [see Appendix A]:

1. Understanding the garrison as it relates to civil society- identifying whether the garrison is within the confines of Jamaica civil society.

2. Understanding the quality of governance in the garrison- how it influences or directs the behavioral norms.

3. Understanding the dynamic between political economy and the garrison- the interplay between politics, social integration and finance and how criminal entities develop within this context. 
4. Understanding the role of governance structures in shaping behavior- agency and citizen responsibility.

Research questions: Taking into account the social construct of the garrison, the first set of questions starts with a definition of civil society and probes whether the garrison is embraced as either a) a part of the Jamaican society, or if it is seen as b) a locality that functions and operates outside the scope of state control.

The interview questions then turn to a focus on the quality of governance within the garrison. Here, the garrison is defined, and its power structure is measured against the performance of state officials and criminal entities. The next set of questions relate to political economy. Here the political and economic influence of criminal community leader are discussed based on a broad spectrum that asked respondents to indicate whether they think that criminal community leaders have managed to accumulate more or less influence within garrison communities over time. Power dynamics between criminal non-state actors, legitimate community leaders, and state appointed community representatives are explored. Collectively, discussions on the quality of governance and the political economy of the garrison were central to the study's theme of examining the transnationalization of the garrison.

The final set of questions asked during the in-depth interviews focused on the respondents' perceptions of how much influence criminal non-state actors have in shaping the behavior of the average citizen. This section aimed at identifying whether respondents perceived of criminals residing within the garrison as a) part of a larger network of criminal actors and actions, or b) as minor, independent criminal actors. Closing questions looked at state response to garrisons by analyzing respondents' 
opinions on the actions taken by the state in the May 2010 incursion into one of Jamaica's most formalize garrisons, Tivoli Gardens.

Focus Groups: Turning to the perspectives of individuals residing within garrison communities, the study constructed a separate set of questions geared toward data collected through focus group discussions. The majority of participants in the focus group discussions were not only garrison community residents from a wide cross section of communities, but also fell under the category of participants identified in the study as 'informal' people. The 'informal' people category comprised of persons who were selfemployed members of the formal and/or informal economy such as shopkeepers, taxi drivers, and vendors, or unemployed persons such as gang members, students, and the elderly. Focus group discussions revolved around three themes [see Appendix B]:

1. Understanding civil society

2. The issue of governance and sources of control and leadership

3. Interpretations and significance of the May 2010 Tivoli Incursion on the image of the state.

Similar to the in-depth interviews, an understanding of civil society is used as a benchmark for awareness, as well as a way to lead into the central questions that frame the discussion. Identifying an 'insider's' perspective on the correlation between the garrison process and its place in civil society is an important element of the study as it helps to either justify or clarify past and present interactions that occur within the garrison, as well as through garrison politics.

The next set of questions focus on issues of governance and sources of control and leadership; these questions are central to exploring the larger themes of the study. 
The questions begin with an understanding of what it means to live in a garrison-- what is understood by the term garrison from the perspective of an 'insider?' The questions then transition to a discussion of whether the image of the garrison has changed over time? How power/control within the garrison was perceived as being organized, and a discussion of the person or group who is really in charge? The exit questions also refer to the May 2010 Tivoli Invasion. The in-depth interview focused on the effectiveness of state responses. The questions directed at the focus groups center on the rights of the state in 'invading' a garrison. The question also focused on the implications that this action has on the interactions between the garrison and the state moving forward.

Observation: Another important instrument used to collect data within the study is participant observations. According to Marshall and Rossman (2010), observation captures a variety of activities that range from either informally hanging out in a specific setting, getting to know people; or more formally learning the routines of individuals or organizations with the aim of recording actions and interactions. "Observations involve the systematic noting and recording of events, behaviors and artifacts in the social setting" (p.139).

During the data collection phase of the study, a contact summary/field form was kept for each focus group conducted [see Appendix C]. The contact summary/field form was an important component of the focus group discussions as the interviewer was able to use it as a means of identifying the complexity of the interactions between persons when voicing their opinions, as well as to record any illuminating moments or reactions that occurred during the discussion. 
In addition, relevant observations taking place surrounding in-depth interviews were also recorded. This included not just visual, but also other applicable sensory observations, as well as incidents that occur before or after interviews. While visiting each of the three case studies, close attention was also paid to how individuals interacted in their natural settings, and notations of interesting points of interest that related to the discussion was also recorded.

Secondary Research Instruments: In addition to interviews, focus group discussions, and observation, secondary research is another important data collection instrument used in the current study. As mentioned above, secondary data employed in the current study includes:

a) Geo-spatial maps of garrison constituencies and communities, and of the Kingston Metropolitan area

b) Community profile reports from the Social Development Commission of Jamaica (SDC)

c) Archival research using publications from the two major newspaper companies in the country: The Gleaner Company Limited and the Jamaica Observer.

d) Analysis of policy reports, national crime reports, and assessment documents related to the garrison.

e) Radio and television interviews, talk radio, and commentary programs from media groups such as Real Jamaican Radio (RJR), CVM Communications Group, Power 106 FM (owned by the Gleaner company), News Talk FM (owned by the University of the West Indies) 
Identifying Prior's (2003) understanding of 'documents' as secondary research data, the study carefully selected secondary data not just determined by content but also paid attention to all documents generated by specific organizations or agencies with a stake in the subject of garrisons. According to Prior (2003) 'documents' are situated products whose content (whether written or electronic) appears in multiple forms including, pictures, diagrams, and audio. Documents involve creators, users and settings and as such are more than just content that should be interpreted. Not only should research take into account the intended function of documents, but also they should considered documents as agents that influence outcomes within the settings they are placed (Prior, 2003).

Further, new technology has also influenced the kinds of data that is collected and recorded, as well as what kinds of analysis can be carried out. Audio recording have extended beyond using simply a tape recorder in interviews and focus groups, towards incorporating documents and texts obtained from mass media outlets (Gibbs, Friese, \& Mangabeira, 2002). By incorporating data from mass media outlets, the study is further able to analyze results in a more complex and dialectic way, recognizing that human interactions are constantly being interpreted, contextualized and decontextualized in dynamic ways.

\section{Data Collection Procedure}

The primary data collection methods are a) semi-structured in-depth interviews among knowledgeable experts on garrisons politics, and two (2) open-ended focus group discussions primarily among individuals residing within a variety of garrison communities selected as part of the multiple case study approach. Sixteen (16) Semi- 
structured in-depth interviews and two (2) focus groups comprised of eight (8) and seven (7) individuals respectively, has resulted in a total of thirty-one (31) respondents sharing their insights on the changing nature of the garrison and its impact on the Jamaican state. Once the preliminary pool of participants were identified and contacted, the data collection process took place in two phases. During the first phase, semi-structured elite based interviews were conducted in Jamaica from July- August 2012 by the main researcher. In February-March 2013, a second interviewer versed in qualitative and quantitative research and in interviewing protocols conducted both focus groups.

Interviews and Focus Group Respondents: Knowledgeable experts recruited as participants in the study were contacted using two methods of identification. The first pool of participants was discovered in preliminary research that extended beyond the literature review on garrison discussed in the study. Key word searches for terms such as 'garrison', 'gangs', 'drugs,' were used to identify knowledgeable individuals who spoke publically on the terms selected. The websites of civil society groups, and quasigovernmental and governmental organizations were searched to pinpoint key professionals across various organizations with a stake in an understanding of garrison.

The second pool of respondents was recruited as part of the snowball effect. Where a new sample of participants is determined based on, recommendations and personal contact information received from a previous respondent. "[The snowball] process is, by necessity, repetitive: [respondents] refer the researcher to other [respondents], who are contacted by the researcher and then refer her or him to yet other [respondents], and so on. Hence the evolving 'snowball' effect" (Noy, 2007, p. 4). Therefore, snowball sampling makes use of natural social networks and helps to identify 
the power relations and social knowledge bases the exist with the Jamaican society as they relate to the subject of garrisons.

Once a list of knowledgeable experts was compiled, each respondent was sent an introduction of the study packet via electronic mail [See Appendix D]. The packet included an informational letter, an investigator profile page, and a reply form. These documents collectively introduced the prospective respondent to the nature of the study. It also provided a brief explanation for why potential respondents had been invited to take part in the study, along with an outline of the larger thematic questions with which the study is concerned.

Although the researcher had some success in establishing initial contact with knowledgeable experts via electronic mail, initial contact via phone calls proved more effective. Phone calls to places of work, allowed the researcher to make contact with personal administrators, and/or leave voice messages for potential respondents. Verbally introducing the study and I typically resulted in a speedy response. If there were no responses to information packets submitted through electronic mail after two days, the researcher would follow up with a phone call to the prospective respondents places of business and do a verbal introduction. Often times, administrative assistance would redirect the email to a personal account, or response on behalf of the respondent by returning the phone call later. The redirecting of the method of communication indicated that in a few cases respondents were viewing initial electronic contacts but seemed to be waiting for a more personal mode of communication.

Regarding contacts obtained through snowballing, respondents having completed the study were primarily willing to give the researcher, personal cell phone numbers and 
private email addresses of recommended persons, rather than work contact information. In fact, several individuals who had been a part of the researcher's initial contact process did not indicate a willingness to participate in the study until they had been contacted a second or third time through information obtained from recommendations. The most nonresponsive pool of respondents came from members of academia and political officials. Often times, the researcher would receive either a non-response, or would receive a response turning down the request to take part in the study either because of conflicting schedules, being away on business, or a lack of interest in making any further comment on the topic aside form what was already publically shared.

Interviews were scheduled for times and locations most convenient for the respondent and last approximately 60 mins. As a result, meetings were conducted at all times of the day and on any day of the week requested including weekends. Interviews took place in private and public spaces such as the workplace, private homes, college campuses, civil society organizations and community centers within garrison communities, private businesses, restaurants, and at the administrative offices of places of worship. Before the start of each interview, the respondent was presented with a confidentiality and quote release form for them to review and sign [See Appendix E]. Respondents were also informed that the interview would be audio recorded, were again reminded of the purpose of the study, as well as how long the interview would last. At that point, any concerns or questions regarding the research or the researcher's background were addressed.

In addition to receiving referrals to speak with other knowledgeable experts, respondents would occasionally refer the researcher to a specific individual or 
organization that resided with a garrison community or that worked in or with an organization based within a garrison area. These types of referrals typically came from respondents who were a part of academia or from the clergy. Interestingly, civil society groups seems intent on giving referrals to other like-minded experts who headed similar organizations, rather than to individuals who reside within garrisons communities but also sought to work with these civil society groups. The research also used respondents' referrals to initiate contact with smaller grassroots organizations located within garrisons communities for focus group discussions.

Post interview discussions facilitated contact with garrison community leaders, and civil society groups willing to take the interviewer into their communities to speak with residents, later. Once all semi-structured interviews had been completed and a timeframe for phase two of the research was established, the researcher reintroduced herself and her research to the individuals who had previously pledged their assistance. The discourse was initiated with a phone call, and it was then followed up with an email. The email contained an informational letter regarding the purpose of the focus group and the main researcher's profile [See Appendix F].

Both by phone and by email, the researcher explained that someone acting on her behalf would carry out the focus group portion of the data collection. By establishing first contact, or in some cases reestablishing contact, the researcher was able to reaffirming the community leaders or organization willingness to assist in finding garrisons residents to participate in the study. From these contacts, two (2) focus groups were arranged for some time in February through March 2013. 
Having arrived in Jamaica, the secondary interviewer established local contact with individuals via phone and scheduled a time and a location for each of the two focus group meetings to take place. The first focus group convened at the administrative offices of a grassroots civil society organization located in a neutral area, outside of any garrison community. While, the second focus group took place in a garrison community at the home of a community leader. Both interviews lasted an average of 60 mins. The primary researcher provided monetary compensation to the individuals organizing both focus groups. Monetary compensation served to thank these individuals for their time, and to assist in the transporting of garrison residents to and from their communities to the location of the focus group. In addition to transportation, "box lunches" and refreshments were also provides for the respondents.

Before the start of each focus group, the interviewer explained the purpose of the focus group and, the confidentiality of the study was reemphasized. Focus group respondents were also required to sign and return their own confidentiality and quote release form at the start of the group discussion [see Appendix G].

The first focus group contained a mixed gender group of eight (8) persons from several garrison communities of varying ages. Despite the repeated assurance of the interviewer throughout the discussion, and the fact that the conversation took place at a neutral location and at a civil service organization with no political affiliation, there remained an undercurrent of concern for their safety and wellbeing when questions related to the action of Don's were asked. Respondents in the first focus group were most vocal regarding the role that the police played in the communities- modeling the "gun 
man mentality" of freely wielding guns, issuing threats, and taking part in corrupt activity.

The second focus group took place within a garrison community at the home of a prominent community leader. As a result, the respondents who took part in this focus group all resided in the community and were all young men between the ages of 18-28 years of age. Perhaps because the conversation took place with the community in which the respondents reside, they were much more apprehensive towards sharing their opinions with the interviewer, in relation to the first focus group. Like the first focus group, they also fostered a rich discussion regarding the role and relevance of the Don within garrison communities

\section{Confidentiality, Ethical Concerns, and Limitations}

Confidentiality: Throughout the data collection segment of the dissertation, the confidentiality and privacy of all persons involved with the research has been maintained and preserved. The study has not only aimed to protect all persons who were interviewed or in a focus group, but it has also extended confidentiality to any persons who played a part in the establishing of contacts with some respondents who otherwise would have been inaccessible for interviewing. The real names of Organizations and communities in which focus groups or interviews took place have also been protected. The interviews and focus groups occurred in the backdrop of the Tivoli Incursion, the Extradition of Christopher "Dudus" Coke, the Manatt-Dudus Commission of Inquiry, and public outcry for both the shooting of upper middle-class businessman Keith Clarke, and the need for a commission of inquiry into the Tivoli Incursion that left approximately seventy-three (73) residents dead. Given the nature of the research being conducted, the context heightened 
expectations for confidentiality among the respondents, specifically those who took part in either of the two focus groups.

During the interviews of elite Jamaicans, respondents were given a Confidentiality and Quote Release Agreement form to sign that assured all interviewees that the interview would be audio recorded and that all information collected would be kept completely confidential [See Appendix E]. During the round of interviews, respondents were also given the option to either having their names and title linked to their quotes or to only have their name appear in the appendix along with the names of other persons who participated in the study (See Appendix H).

None of the interviewees who participated in the study refused to be recorded, however twenty-five (25) percent of them refused to have their names linked to any quotes if used in the study, and agreed only to have their names listed alongside others in the appendix. Although the majority of respondents indicated some discomfort in having their names and opinions used in the study, the interviews were carried out and respondents generally requested that specific segments of their responses during the interview, not be tied publically to their names. When names of certain Dons and/or politicians where revealed, and relationships or activities were mentioned- such as the behind the scenes details of the Tivoli Incursion- a few respondents asked to have those particular tidbits of information marked as anonymous. A few respondents also waited until the end of the interview when the audio device was turned off to voice their concerns, or to share information they did not want to voice on the tape. In one instance, a respondent contacted the interviewer several hours after their interview, via phone, to clarify a point they had made on record earlier. 
Unlike the interviews with elite Jamaicans that allowed respondents to choose to have their names tied to their statements, individuals in the focus groups were provided with complete anonymity. Cognizant of their day-to-day interactions in garrison communities, the research took extra precautions in ensuring that the views and opinions of individuals taking part in the focus group would not be tied to any specific community, organization, or aliases. The Focus Group Consent Form [see Appendix F] was read to respondents at the start of the focus group before the discussion began, and before the respondents signed them. Throughout the discussion, the interviewer reminded respondents that even though they were being audio recorded, that their names would not be tied to their comments, and that no real names would be used in the study. Over the course of both focus groups, the interviewer often chose to remind respondents of the study's privacy and confidentiality when they were not responsive to certain questions, or when in the midst of sharing an opinion they suddenly stopped talking.

The withholding of information is a common feature of Jamaican society and is generally referred to by the Jamaica Constabulary Force (JCF) as a 'culture of silence'/ 'anti-informer culture' (Hill, 2011), or as Hume Johnson (2011) more recently refers to as 'informerphobia'. Often revealed in song lyrics and Jamaican films, informerphobia is a phenomenon embedded in the political and civic culture of garrison communities. It is normal for garrison residents to be killed after sharing information with law enforcement officials regarding other community members or illegal activities (Johnson \& Soeters, 2010). ${ }^{11}$ In the cases where individuals were not killed, they and their families fled their

\footnotetext{
${ }^{11}$ Johnson, H., \& Soeters, J. (2010, May 2). Informerphobia (part 1). The Gleaner. This article highlights four of several cases in which informers have been killed.
} 
communities and have been ostracized from others within its vicinity. As Johnson (2011) points out, for the criminal group the fear of informing is a critical part of the social and political control that it exerts over its residence. The fear and control wielded by the criminal entities within the garrisons allows it to conducts illegal activities, while allowing it to preserves its political relevance to the state. Unquestioned loyalty and confidentiality leads to freedom to carry out illegal activity within the community without repercussions, and indicates to the party mechanism that political votes are guaranteed without fail.

Although this culture typically is relegated to the sharing of information with law enforcement officials such as the police, there had been a few instances in which academic publications have led to the punishment or to the killing of individuals residing within specific communities. The repercussions of information sharing have also led to the cautionary release of certain publications, on the island, containing revealing political content. ${ }^{12}$ During the first focus group, one respondent (from Focus group A) went so far as to interrupt another respondent when speaking to remind them that they were being recorded. This prompted the respondent to immediately stop talking. Some nervous chuckling resonated around a silently growing room and the interviewer reminded the respondents that their names were not timed to the discussion, nor would they be used. Respondent B continued to remind respondents from time to time throughout the entire discussion of the presence of the recording. At the end of the first focus groups, half of the respondents seated near Respondent B requested their Confidentiality Release Form

\footnotetext{
${ }^{12}$ See Gunst, L. (2003). Born fi' Dead: a journey through the Jamaican posse underworld. New York: H. Holt. And Small, G. (1995). Ruthless. The global rise of the yardies. Warner.
} 
back and crossed out their names where they had written them, choosing instead to leave a marking acknowledging their involvement.

Ethical Considerations: by conducting qualitative research, the current study attempts to "collect data from people about people" (Punch ctd. in Creswell, 2009). As a result, the researcher is aware of the ethical responsibility that must be fulfilled during the carrying out of the current study in order to maintain the trustworthiness- validity and reliability- of the qualitative research (Orb, Eisenhauer, \& Wynaden, 2000).

Before the start of each interview and at the start of both focus groups, the researcher reviewed the purpose of the meeting, the purpose of the study, and the expected involvement and role of both the interviewer and the respondents. During the time that the interviewer spend with respondents, questions where asked using a neutral tone, special care was taken to not lead respondent answers, or to highlight the views or opinions of the interviewer. At the end of each interview and discussion, time was set aside to talk with respondents interested in learning more about the interviewer and their views. The sharing of information related to the interviewer occurred when all questions had been answered and referrals had potential interviewees had been collected.

Given the directness of some of the questions asked in both the elite based interviews and the focus groups, the interviewer's experience with previous interviews allowed for changes in the way that specific questions where phrased. Certain questions of some categorical divisions of the interviewee would lead some respondents to say less or more depending on the weighted bias they assumed the question carried. For example, when interviewing political officials, questions that dissected the interaction between the power dynamic within garrisons and the state were regarded as offensive and were 
approached delicately. While, when media practitioners and community/civil group individuals were asked the same question, they more freely shared their understanding and even provided examples. Earlier interviewing experience also helped to identify which questions were better obtained seamlessly as a part of responses to another question. An increasing familiarity with how to most effectively pose questions to obtain relevant responses meant that some questions although stricken from the interview, still were measured in responses given to other questions.

Many of these discussions helped to frame a better understanding of the views of the respondents and their contribution to the public discourse on the themes of the study. The contribution of some respondents to the public discourse on garrisons emphasized an important ethical issue as more than $90 \%$ of respondents in the interviews of elite Jamaicans did not live or work within garrison communities or areas. Yet, they possessed an in-depth knowledge of garrison happenings and dynamics through their organizations and professional careers. Their outsiders' perspectives often times framed public perceptions regarding the garrison in Jamaica.

Further, the study recognizes one of the shortfalls of including respondents recruited by other respondents, referred to as snowballing sampling. First, the snowballing effect influenced the selection process of respondents who were not a part of the first list of individuals identified in the study. By referring the interviewer to other elites, a respondent often times is directing the interviewer to other individuals who tend to have a similar viewpoint as them. In addition, referrals tended to highlight individuals within the same vertical network of professional interactions as the referring respondent. Approximately $44 \%$ of the interviews of leaders/officials were conducted among 
individuals who worked primarily in a civil service organization. Another $38 \%$ of respondents interviewed identified themselves with other professions, yet they sat on the board and/or founded key civil service organizations. In a few situations when the primary interviewer was unable to get in contact with potential interviewee via the formal channels, access was made based on family relationships and friendships.

The snowballing effect also influenced the focus group participants selected for the study. By relying on specific community leaders and grassroots civil service organizations to arrange participants, the study risked speaking only with individuals, who were generally in favor of the organizations, their role within the community, and their points of view regarding the garrisons. The perspective of the respondents could have influenced some of the questions asked during the focus group that relate the performance of various civil service groups negotiating interactions between garrison communities and the state. However, as grassroots civil service groups are effective at the community level-influencing mainly one or at the most two communities - the particular issue was dampened by the fact that within the first focus group, respondents came from a wide cross section of communities that may or may not have been influenced by the organization that hosted the discussion. Regarding the second focus group, the study sought to focus on respondents where were all male, and within the age group of community members $18-28$ who typically were expected to become a member of the area gang. The ability to speak with this subgroup in individuals in order to gather greater insight into the community dynamic outweighed the community bias present.

Limitations: As Patton (2002) rightly points out, "There are no perfect research designs. There are always trade offs" (p.223). Given the sensitive nature of some of the 
questions being asked, and the backdrop of the Tivoli Incursion and other variables addressed in the start of this section, the researcher made the decision prior to data collection phase of the study, to not interview any current dons or any active gang members. During one interview of a Jamaican elite, one respondent went as far as to direct the researcher to a specific gang member who was mobilizing his gang to fill a power vacuum in a community that had recently lost its don. The respondent had contacts in the community and at the end of the interview made a direct phone call to the individual informing him that he was to expect a call from the researcher. Over the phone and in my presence he vouched for me and arranged for me to have safe passage into the community. After the phone call, the respondent preceded to tell me that because of the current power move the gang leader could only meet with me in the community and it would have to be held indoors given the unstable situation. For security reasons, I declined to follow through on the interview.

Another limitation to the study was the ability of the research to access political officials and security professionals. The ability to access these individuals through their organizations, offices and gatekeepers proved very time consuming and difficult. Often times when contact successfully was made, their schedule and public duties resulted in postponed interviews or their unavailability. In one instance, the research had to remove a respondent from the interview list after cancelling two scheduled in-person interviews and two scheduled phone interviews.

On the other hand, the research found that community/civil group individuals were the most accessible. The category of respondents although representing various interests and civil issue platforms, maintained a political network of interactions that 
worked perfectly during the snowballing process. The one limitation with this group was that civil service groups generally were divided into two groups: middle class driven civil service organizations and grassroot community based organizations. The respondent found grassroots organizations to be most willing to connect the researcher with the communities being studies. Some middle class civil service organization respondents were not responsive to the multiple attempts of the research to contact them until a colleague directly referred the respondent to them. There was quiet a bit, of "name dropping" used among this group.

Further, when attempting to schedule focus group meetings, middle class organizations were less helpful in connecting the respondent within the community. One organization founder, who was previously unavailable for an elite interview, managed to direct me to an organization representative whom I contacted regarding focus group assistance. The referred contact then expressed irritation that they were being inconvenienced with the passed on task of helping me find individuals in the community organizations interesting in taking part in a focus group. There was also expressed irritation that the task assigned to the individual was in the form of a forwarded email rather than a direct request from their mentor. The perceptions of the particular contact made it difficult for the researcher to work with specific organizations.

The timing of two major social events in Jamaica had also negatively influenced the first phase of the data collection process [July-August 2012] of the study. The first was the 2012 Olympics; the second was Jamaica's 50th Independence celebrations. Sports in Jamaica, is a significant part of the country's culture. During interviewing phase 
of the data collection, Jamaica's role in the 2012 Olympics influenced the timing of interviews and the commute to interviews during that period. The prominence of Jamaican athletes in the track and field segments of the Olympics resulted in a surge of national pride and celebration. At the one of the most important transportation hubs and intersections in Kingston- Half Way Tree- known as Jamaica's Times Square, large television screens were erected to show all races involving a Jamaican in real time. During race times and especially where Jamaican athletes had prevailed, traffic came to a standstill as jubilant crowds flocked the streets in celebration.

The Jamaica 50 Celebrations commemorating 50 years of independence also negatively influences the data collection phase of the study. In addition to the regular Island-wide festivities for Independence, Jamaica 50 celebrations was marketed as a significant historical marker for the country, and cause for greater celebrations. The festivities extended to the upper middle class party culture of mass migrating to Jamaica's coastal areas for the long weekend of independence to party and to relax. What is traditionally a long weekend was extended to a week long series of events spanning all along the northern coast, catering for all ages. The last week of interviews suffered from elites out of office towards the latter part of the week, and requests to call and schedule meeting postponed. What interviews took place during that last week were crunched into the first two days of the week creating problems of scheduling and organizing final interviews based on importance by the researcher.

Other limitations to the study involved the use of a secondary interviewer during the focus group phase of the data collection, and the cautious approach of focus group participants in taking part in the discussion and in the nature of some questions. By 
outsourcing the focus group, the researcher risked losing the advantage of applying insider knowledge gathered from previous interviews that could have been applied to the redirecting or focusing of specific focus group responses in relation to the responses of their elite counterparts. Focus group discussions also revealed that some questions where understood differently by focus group participants versus elite based respondents, such as defining civil society. 


\section{CHAPTER 3}

\section{FROM THE GLOBAL TO THE LOCAL}

"No space disappears in the course of growth and development: the worldwide does not abolish the local"- Henru Lefebvre, La production de l'espace

The first chapter laid the foundation for the notion that there are few if any works that focuses on the transnational nature of the garrison. It revealed that there was minimal research on how the garrison, as a non-state actor, has been able to increasingly shape the type and nature of the issues and policies that the Jamaican state engages in, thereby “making policy processes more 'pluralistic', 'complex', and 'fragmented"” (Moravcsik, 2009, p. 245). Remaining firmly embedded within the confines of the Jamaican state, the garrison is able to act local while embracing global strategies and goals. In this way, it is carrying out transnational linkages that " impose new external constraints and opportunities on state behavior and alter the nature of relative interstate power" (Moravcsik, 2009, p. 246). In the case of the garrison, these transnational relationships also alter the power dynamic between garrisons and the state.

How do garrisons utilize the global relations and processes of communication, transportation, finance and travel to become more transnational over time? Chapter 3 examines the process of transnationalization occurring with the Jamaican garrison. Its focus is on how the interactions carried out by criminal elements within garrisons are distinctly transnational. The flipside of transnational relations considers how garrisons identify has been reinforced and, how they have been modified because of the web of transnational ties (Moravcsik 2009). The leading scholars of transnational relations, 
Keohane and Nye (1971), attest that the process of transnationalization is understood as a series of actions or steps taken by non-state actors over time that alter dimensions of world politics. More specifically, transnationalization is understood as a process intensified by increasing levels of globalization (Durrschmidt, 2004).

\section{Globalization: Revisiting Theoretical Underpinnings}

There is a multitude of examples to draw from that not only re-enforce a wholesale acceptance of globalization as a real and significant global force, but that also suggests that globalization is an inevitable process of global transformation. Some scholars point to upsurges in the flow and density of migrant populations, the multiplication of terrorist activities resulting from technological innovation, and to the increasing economic and political integration of states and the successful expansion of multinational conglomerates across the planet (Friedman, 2012). ${ }^{13}$ Other perspectives point to the embrace of neoliberal economic strategies by states and by intergovernmental and nongovernmental actors as a disturbing foretelling of global change (Hebron \& Stack Jr., 2010).

Yet, despite the forcefulness of these attestations globalization as a concept, process, and as a theory has been, and continues to, be highly contested in academic circles. Jones (2010) points out, that globalization has become an overused and overhyped concept. One that "has become so pervasively known that it is becoming taken for granted, and few people question what it really means or even why it is important" (p. 1). Globalization conjures up images of nation-states unavoidably staring down the barrel of

\footnotetext{
${ }^{13}$ Multinational conglomerates like North America's General Electric, Latin America's Petrobras, Asia's Mitsubishi Group, and Africa’s Bidvest group Limited
} 
a borderless world, helplessly standing aside as open borders allow local markets, cultures, and identities to be swept away by distant events and processes (Hebron \& Stack Jr., 2010).

Loaded with metaphors and visuals, there are many works like Stephanie Black's (2003) film Life and Debt that reveal the reality of globalization distinct from globalization as a theoretical construct. The film speaks of the destabilizing economic and social conditions that take place in developing countries, such as Jamaica caught up in the globalization process and forced to implement global policies that never seem to reflect nation-state interests. International loans by the International Monetary Fund (IMF) and the World Bank realistically come to the developing world at a higher price of devalued local currency relative to the dollar, with high interest rates on investments and the elimination of tariffs and import tax on goods entering the country. Ultimately, Life and Debt represents a broad spectrum of works that tell the story of nation-states at war with globalization, as it is increasingly unable to reduce poverty, control violence, and meet the social service needs of its people.

While there is substantial worth to be found in exploring the diminishing role of the nation state, vis-a-vis evolving and new global entities, generalizations and arguments concerning the well oiled and multiple processes of globalization typically redirect reflections of the diminishing and changing state roles to predictions of its likely demise. If we retrace our steps, back through the works of Stephanie Black (2003) and Veseth (2006, pp. 1-10), it is clear that analyses that focus on the peeling back of the layers of globalization reveal its complexity. Globalization is a highly variable process. Each case reveals that although globalization is indeed path dependent, there are multiple paths that 
have been, and that can be taken. Most importantly, as Veseth (2006) points out, with every headline or story, pertaining to major global issues we learn that:

Globalization is real, and we must take it seriously, but it is not easy to understand because of its complexity. Globalization is not one single thing; it is a collection of things, tightly intertwined, some loosely connected if at all (p.1).

Understanding Globalization. Within the scope of the current study, globalization is understood to be a long-term, decentralized, and multi-pronged process (Giddens, 1990; Urry, 2003; Harvey, 2000; Castells, 2000) where social, economic, and cultural forces have become de-territorialized (Giddens, 1990; Scholte, 1996; Ruggie, 1993; Conway \& Heynen, 2006; Harvey, 2000; Robinson, 2004) and increasingly socially integrated (Rosenau, 1990; Keohane \& Nye Jr., 2000; Castells, 2000). In more general terms the process of globalization is concerned with the spread of new forms of non-territorial activities and with how distant events and forces influence activities that occur at the local, national, regional, and global levels, or as Giddens (1990) puts it, with the "intensification of worldwide social relations which link distant localities" (p. 64). Globalization constitutes a thickening of interdependence that is transcontinental in scope (Keohane \& Nye Jr., 2000).

A Long-Term, Decentralized, and Multipronged Process. For Giddens (1990) what is central to globalization is that it is comprised of a complex set of processes or events that simultaneously work with and against each other. These processes force an increasing occurrence of relational dialectic between individuals, groups, and organizations, where decisions and events entail multiple viewpoints and components that often contradict each other. It is this facet of globalization that allows it to radically 
reorganize and reconfigure multi-scale relationships, by allowing multiple distant influences to affect the local and the national regardless of whether an individual, group, or organization actively takes measures to becomes more globally fluid. For Giddens (1990) "Globalization not only pulls upwards, but it also pushes downwards, creating new pressures for local autonomy...[it] also squeezes sideways, creating new economic and cultural zones within and across nations" (p. 31). In this way, globalization is becoming increasingly decentralized.

Similarly, Castells (2000) argues that the globalization process is comprised of spaces of flows and network societies. Where key social organizations are actually networks or dynamic structures that are organized around flows of communication and information and; spaces of flows virtually connect distant physical locations by way of these networks organizations. More importantly, Stadler points out that Castells's "spaces of flows does not replace geographical space, but rather by selectively connecting places to one another it changes their functional logic and social dynamics" (as cited in Jones, 2010, p. 59). From a perspective of spaces of flows and network societies, the global system is a system with no center or set concentration of power (Castells, 2000). The complexity inherent in the globalization process makes it diverse, historical, fractured, and uncertain, leaving it also with no single center of power (Urry, 2003, p.x).

Primarily because "[globalization] encompasses tensions between the core and periphery, between national and transnational systems...between states and markets...urban and rural...[and] between global and local," (Rosenau, 1996, 4-5) it is messy, uneven, and complex. These tensions are simultaneously integrative and 
disintegrative. Scholars such as Castells (2000), Harvey (2005), and Robinson (2004) attributes these 'tensions' to the restructuring of capitalism, which has in turn lead to uneven development at multiple levels of interactions (Castells, 2000, p. 9). More specifically, they argue that this uneven development is as much an outcome of the process of restructuring as it is about the imposition of the process by "some hegemonic outside power" (Harvey, 2005, p.115).

Robinson shows that these asymmetries are not just geographically distinct but that they are also social, "[there are] new social hierarchies and forms of inequality emerging under globalization" (Robinson, 2004, 72-73). Running alongside capitalism, Harvey (2005) characterizes globalization by uneven development and argues that it is not a continuous or gradual process. Rather, globalization is distinguished by intense and unexpected bursts of time-space compressions (Harvey, 2005, p. 4), and it is defined by space understood as power relations that constitute social life (Lefebvre, 1996). ${ }^{14}$

Deterritorialization (Delocalization). The discourse on time and space as a central process behind globalization has also lead scholars to explore another key dimension of globalization- the concepts of territory and scale. The occurrence of immediate interactions and prompt access to information and data from any location in the world to another implies, to some extent, that territories and distance have become irrelevant to the processes of globalization. As such, Harvey (1991) understands globalization as intense and unexpected bursts of time-space compressions that have

\footnotetext{
${ }^{14}$ Here space is defined as power relations that constitute social life, as opposed to being understood as an empty vacuum in which social life takes place.
} 
created and conditioned interactions that increasingly take place in a virtual space unaffected by time and distance.

Similarly, globalization is also used to illustrate that there is significant delocalization causing social and economic exchange across the world (Giddens, 1990; Gray, 1998). Here delocalization is seen as the uprooting and displacement of activities and relationships from local origins and cultures, into networks of relationships whose reach is distant (p. 57). It is important here to point out that given the displacement of multiple activities and relationships, time is also considered multiple and comprised of a vast array of both centering and decentering mechanisms (Adams, 2009). Driven by new information and communications technology, Castells (2000) argues that a new economic order or brand of capitalism is being conditioned by "unprecedented speed and complexity in the management of the economy" (p. 53). Three fundamental features characterize this new brand of capitalism:

[First,] productivity and competitiveness are, by and large, a function of conditioned knowledge generation and information processing; [second,] firms and territories are organized in networks of product, management, distribution; [third,] the core economic activities are global- that is they have the capacity to work as a unit in real time, or chosen time, on a planetary scale (As cited in Hutton \& Giddens, 2001, p. 52).

Focusing on the third feature, Castells (2000) uses the concept of real-time or timeless time to reinforce an understanding of delocalization. He asserts that advances in information technology has made it increasingly possible for strategically crucial economic activities' such as capital markets, media communications, entertainment and 
even global crime to manipulate the natural sequence of events to meet relevant time zones (Castells, 1999). Activities, such as 24 hour banking, live reports of the March 11, 2011 tsunami in Japan immediately affecting the U.S Stock market, ${ }^{15}$ and front row seats to the 2012 Olympics in London live from your living room in Kingston, Jamaica. These all contribute to the ability of humans to access the global and to retrieve information and access to real world activities from home.

More explicitly, Scholte (2000) defines globalization as the terminology used to describe 'something different' occurring in the world. That difference is the occurrence of relative deterritorialization. Globalization is deterritorialization and the growth of supraterritorial relations between individuals, where the something new refers to changes in the nature of macro social space so that "some aspects of social space are no longer reducible to territorial geography" (p. 42). For Scholte, understanding globalization as internationalization, liberalization, universalization, and westernization or homogenization conveys no new processes or interactions taking place in the world. Moving the discourse on deterritorialization beyond an understanding of geography associated with territory, Scholte (2000; Scholte \& Schnabel, 2002) highlights a wide array of global activities that are non-territorial. Where Gray (2005), Harvey (1991), and Castells (2000) stress the ability of humans to access the global from home, Scholte pushes further by stating that global activities reconfigure perceptions of what truly constitutes a sense of place. Supraterritorial activities like communications, markets,

\footnotetext{
${ }^{15}$ Associated Press. (2011, March 14). Fears of economic impact of earthquake, tsunami on Japan lead to broad sell-off on Wall Street. Retrieved September 21, 2013, from Masslive.com: www.masslive.com/news/index.ssf/2011/03/fears_of_a economic_impact_of.html Concerns over the economic impact of the massive earthquake and tsunami in Japan, the world's thirdlargest economy, led to a broad sell-off in the stock market
} 
production, money, finance, organizations, social ecology, and consciousness, all allow for interactions that are in no way related to the local.

Beyond time-space compression and the simultaneous occurrence of events, supraterritorial activities create new types of connectivity between people that do not require verbal communications, face-to-face interactions, and an intimate knowledge of local customs. Global definitions of community are no longer confined to notions of specific or limited physical space, rather, supraterritorialism allows for a new sense of place that is neither here or there, but that allows for communication and interaction to take place between new and different categories of people.

What Drives the Globalization Process? Given the affect that globalization has on social, economic and cultural forces, scholars such as Eriksen (2001), Scheuerman (2004), Harvey (1991), Keohane \& Nye (2000), and Hebron \& Stack Jr. (2010), remind us that this effect is always a matter of degree or a matter of depth. Globalization's influence is based on the degree of speed/velocity of the flow of people, capital, and goods taking place across multiple continents. However, what are the main driving forces of globalization? What variables enable the globalization process to utilize increasing interconnectedness to speed up and intensify social interactions? The literature on globalization reveals that the debate on the main force behind globalization continues to center on economic variables. Despite the fact that the academic discourse concedes to the relative importance of, technology, politics, institutions, and culture as important drivers of globalization (Jones, 2010). 
Although it is often hard to isolate the political, social, cultural, and economic forms of globalization, Dickens (2011) contends that the primary movers and shapers of our daily lives are firms. The activities of corporations within a rapidly changing technological environment are constantly transforming the global economy and our daily lives via an increasingly complex geography of production, distribution and consumption. The significance of these qualitative changes are not so much a matter of changes in the volume of economic activities but rather they are a matter of changes in its composition. Economic activities are becoming more extensive and increasingly more intricate (p. 4). Similarly, Harvey views globalization as a political project that "[is concerned with] the socio-spatial relations between billions of individuals" (Harvey, 2000, p. 16). As such, globalization is manifested as an economic and political process that simultaneously drives, fixes, ${ }^{16}$ and runs alongside capitalism. More specifically, globalization is discerned as information technology ${ }^{17}$ that has fueled a) the global reach of capital and production, b) legitimized the deregulation of financial markets, c) promoted a reduction in the role and the power of the state, and d) assisted in disempowering trade unions and other working class movements (Harvey, 2000, p. 13).

Others scholars such as Conway and Heynen (2006) also see globalization as manifesting itself in terms of technology. For them, two interrelated phenomena have played a critical role influencing global interactions. The first is technological change,

\footnotetext{
${ }^{16}$ Harvey, D. (2005). A Brief History of Neoliberalism. Oxford Unversity Press. Harvey, D. (2000). Spaces of Hope. Berkeley: University of California Press page 7. Harvey argues that capitalism is flawed and that it requires occasional spatial fixes that allow it to reorganize itself.

${ }^{17}$ Harvey, D. (2005). A Brief History of Neoliberalism. Oxford Unversity Press.pages 1-4, 69-70. "[The process of neo-liberalization] requires technologies of information creation and capacities to accumulate, store, transfer, analyze, and use massive databases to guide decisions in the global marketplace."
} 
and the second in the spread of technological training and expertise. Where technological change refers to "changes in processing and disseminating information related to finance, production, logistical systems of transportation, information services and consumption" (Conway and Heyen, 2006, p. 4).

Nonetheless, while most scholars also see globalization as characterized by information and technology, some disregard technology as its impetus. For Robinson (2004) the control and decision-making powers among elites in competition of profit maximization, is viewed as the driving force of globalization. In this way, globalization is viewed as the final stage of capitalism. Characterized by information and technology, globalization is a structural process that modifies relationships by focusing on the intensive expansion of capitalism (Robinson, 2010). ${ }^{18}$

A Place for the state in globalization theory? Overall, there has been a strong focus on globalization as a process that is primarily understood to (a) run parallel to capitalism (Harvey 2005), (b) as a process indicating a more advanced stage of capitalism (Robinson 2004), or yet still (c) as a process that is driven by economics and consumed by technological forces (Dicken 2011; Castells 2000; Rosenau 1990). Subsequently, this view of globalization is often times piggybacked with the view of an eroding state. Not only is the power of the domestic state withering away, but also state power at the

\footnotetext{
${ }^{18}$ Robinson, W. I. (2010). Latin America and Global Capitalism: a critical globalization perspective. Johns Hopkins University Press pages 6-7. Robinson sees capitalism as expanding both extensively and intensively. Where, extensive capitalism refers to the geographic reach of capitalism. According to Robinson capitalism has achieved extensive enlargement beginning with " the wave of colonizing of the late $19^{\text {th }}$ and $20^{\text {th }}$ century, and ending with the re-incorporation of the former Soviet-bloc and Third world revolutionary states in the 1990's." Intensive enlargement refers to the all societies not just experiencing capitalism, but embracing its logic of accumulation.
} 
international level is seen also as declining in lieu of global capitalism, global governance, and global civil societies.

What Robinson asserts, is that globalization is revealed by first, any shifts in the capitalist system to indicate a move from national circuits of accumulation to global circuits of accumulation; and second, a simultaneous concentration and centralization of world economic management (Robinson 2004, 11-14, 21). However, Robinson does not see the territorial state as obsolete. Rather, he sees states as still important, but only in their ability to provide the security and the jurisdiction required by the transnational capitalist class from time to time, as they strive to maximize profits. Distinguishing between state and nation, what he argues is in danger of becoming less relevant, is the concept of nationhood. He references Strobe Talbot ${ }^{19}$ as saying, "within the next hundred years...nationhood as we know it will be obsolete, all states will recognize a single global authority" (Robinson, 2004, p. 85).

In recognizing that power and control are becoming horizontal [operating across states] as opposed to just vertical [operating within states], Robinson points out that transnational groupings and organization are becoming increasingly less dependent upon the institutional framework of the state (Robinson, 2004, p. 16). He also characterizes state power as still relevant [although limited], and something that is not only being influenced by globalization, but that is also affected by the continued drive of the class based groups to maximize power. However, the interests of the transnational capitalist

\footnotetext{
${ }^{19}$ President Bill Clinton's former Deputy Secretary of state, Former US Ambassador to the UN, Deputy Secretary of state, and now President of the Brookings Institution.
} 
class are not the only interests that the state represents. The role of the state extends beyond merely providing security and jurisdiction for economic forces.

[Transnational interactions] still takes place in a world that continues to be very much politically divided into nation-states that are unequal in their power and which serve differentially as base areas for international capital. Nation-states although they exist within the worlds capitalist system, continue to control armies and nuclear weapon (Glick Schiller, Green Basch, \& Scanton Blanc, 1992, pp. 78).

Further, by acknowledging that states play an active role in the globalization process, Rosenau (1990) asserts that states do so through the ability of individuals and collectives to re-conceptualize, dissect, and understand change. He argues that the analytical perspective of the individual and their ability to learn is the most important parameter necessary for dynamic change to occur within the international realm. Individuals become better able to do so because of technological advancements and access to communications that allow political elites to enhance their ability to learn, and enhances the actions of states. "[Globalization is] not a mystical force leading to the world to a predetermined destiny. Quite to the contrary, it is a result of decisions made continuously by individuals and their collectives and visa versa" (Rosenau, 2003, p. 22).

\section{Moving towards a Transnational Approach to state Interaction}

Differing in scope, scale, and reach, transnationalization while embodying globalization, is a related but distinct process. Like globalization, transnationalization is accelerated by improved transportation, technology, and telecommunications (Held, McGrew, Goldblatt, \& Perraton, 1999). However, where globalization processes are 
concerned with "spaces of flows" (Castells, 1997), transnational processes are anchored simultaneously to specific localities and between specific actors while transcending multiple ones (Smith M. P., Transnational Urbanism: locating globalization, 2001). As Smith \& Guarnizo (1998) state, "transnational practices do not take place in an imaginary 'third space' (Bhabha, 1990; Soja, 1996) abstractly located 'in between' national territories" (p.11). Rather, transnationalism is understood as economic, social, and political interactions among state and non-state actors crossing national borders (Vertovec, 2009). Transnational activities are those that are initiated and sustained by non-state actors who are interested in shaping outcomes, be they political, social, or economic; at home, abroad or on a global scale.

Transnationalization from below. The current study suggests that transnational actors in Jamaica are comprised of networks of individuals who modify state policies through their ability to generate innovation, to mass produce, and to market their services and products (Baumol, Litan, \& Schramm, 2007). The ability of transnational actors to modify state policies is true not only of the transnational capitalist class-a new class of political, social, and economic elites born out of the dominant capitalist class (Robinson, 2004), but also of local grassroots elites who evolve out of criminal violent and social networks, as well as disenfranchised groups and movements. ${ }^{20}$ The current study in interested in the process of transnationalization occurring within the Jamaican garrison. That is, the study is primarily concerned with transnational relations that occur among and between gangs and residents within Jamaica's urban slums. Utilizing global forces,

\footnotetext{
${ }^{20}$ Sikkink, K. (1993). Human Rights, Principled Issue-Networks, and Sovereignty in Latin America. International Organization , 47 (3), 411-441. Sikkink talks of the distinction between elites that reproduce traditional power- relations [top down elites] rather than transform power relations [bottom up elites].
} 
individuals and drug traffickers are able to take part in criminal activities spanning two or more nations while remaining firmly grounded in the daily lives, activities and social relationships of every day actors within the garrison. ${ }^{21}$

The success of transnational criminal gangs to shape and frame outcomes, takes place within a global system that allow these non-state actors a broader political space in which to act. Exploring the political spaces available to local actors within a global system, Cox (1998) differentiated between spaces of dependence and spaces of engagement.

Spaces of dependence are defined by those more-or-less localized social relations upon which we depend for the realization of essential interests and for which there is no substitute elsewhere; they define place-specific conditions for our material well being and our sense of significance. These spaces are inserted in broader sets of relationships of a more global character and these constantly threaten to undermine or dissolve them...In so doing they construct a different form of space which I call here a space of engagement: the space in which the politics of securing a space of dependence unfolds (p. 2)

By forming networks in order to influence state outcomes at multiple scales, non-state actors are in a better position to protect their local interests and assume some degree of control (direct or indirect) over geographic areas. Smith (1998) reaffirms however, that "the realization of interests and identities though networks does not erase arenas of confrontation, accommodation, and resistance among and between [local] agents" (p. 36-

${ }^{21}$ See the works of Basch, L., Glick Schiller, N., \& Szanton Blanc, C. (2003). Nations Unbound: Transnational projects postcolonial predicaments and deterritorialized nation-states. Routledge. And Kearney, M. (1995). The Local and the Global: The antropology of globalization and transnationalism. Annual Review of Anthropology, 24, 547-565. 
37). Whether we are witnessing local politics or the localization of global politics in a global system does not detract from the importance of the local and the political nature of transnational relations among non-state actors from below.

Enhanced transnational connections. The manifestation of globalizing forces is revealed not only by an increase in transnational interactions, but also by regular and sustained interactions over time and across borders (Portes, Guarnizo, \& Landolt, The Study of transnationalism: pitfalls and promise of an emergent research field, 1999). Examining Dominican migrants at home and abroad (Itzigsohn, Cabral, Hernandez Medina, \& Vazquez, 1999), reveals the complexity of a growing number of ties and the increasing fluidity and diversity of transnational exchanges that fall along a continuum; A continuum that ultimately identifies a complex web of transnational networks. What this reveals is that transnational networks consist of not just multiple activities, but also how transnational activities occur at multiple levels-- individual, communities, regional and intrastate institutionalized structures. ${ }^{22}$ Further reinforcing the complexity of the transnational interactions, Vertovec (2001) points out that, "participation in one transnational social formation might lead to, or overlap with, another" (p. 5).

As non-state actors carry out transnational interactions across boundaries, interactions are forged along networks. Where individuals, communities and institutionalized structures are identified as a node or connection point that links with others to form a network. One advantage of a network is its ability to form interpersonal

\footnotetext{
${ }^{22}$ See the works of Portes, A., Guarnizo, L. E., \& Landolt, P. (1999). The Study of transnationalism: pitfalls and promise of an emergent research field. Ethnic and Racial Studies , 22 (2), 217-237; Mahler, S. (1998). Theoretical and Empirical Contributions Towards a Research Agenda for Transnationalism. In M. P. Smith, \& L. E. Guarnizo, Transnationalism from Below. Transaction Publishers.; Nye, J. S., \& Keohane, R. O. (1971). Transnational Relations and World Politics. International Organization , 25 (3), 721-748.; and Smith, M. P. (2001). Transnational Urbanism: locating globalization. Wiley-Blackwell.
} 
relationships across scales of interactions [individual, communities, institutionalized organizations], as well as across territories. Not only do networks create interdependent relationships, but they also provide opportunities for, or constraints on, actions. They allow for the transfer of resources, partnerships, and the exchange of information across voluntary and flexible patterns of interactions that are functional and mediated, and based on expertise. ${ }^{23}$ By creating relationships across multiple scales of interactions, non-state actors work together in a horizontal power structure that utilizes a non-state actors' ability to mobilize resources on demand; ${ }^{24}$ an ability that can only be realized by their membership in networks. This creates what Vertovec (2001) identified as enforceable trust; based on social rewards and sanctions that determine legitimacy, non-state actors are able to pursue mutual interests and to cultivate long-term contacts within a system of flexible linkages.

The Local Embeddedness of Transnational Actors. While globalization scholars such as Gray (1989), Harvey (1991), Castells (2000), and Scholte (2002) acknowledge that global activities are redefining local interactions, they seem to overlook the fact that global activities are shaped by transnational practices embedded in specific

\footnotetext{
${ }^{23}$ See the works of: Wasserman, S., \& Faust, K. (1994). Social Network Analysis: Methods and applications (Vol. 8). Cambridge University Press. page 4; Vertovec, S. (2001). Transnational Social Formations: Towards conceptual cross-fertilization. University of Oxford.; and Arias, E. D. (2006). The Dynamics of Criminal Governance: Networks and social order in Rio de Janeiro. Journal of Latin American Studies , 38 (2), 293-325.

${ }^{24}$ Portes, A. (1995). The Economic Sociology and the Sociology of Immigration: A conceptual overview. In A. Portes, The Economic Sociology of Immigration: Essays on networks, ethnicity, and entrepreneurship. Russell Sage Foundation. Page 12. Portes describes this as social capital. "Social capital refers to the capacity of individuals to command scarce resources by virtue of their membership in networks or broader social structures...the resources themselves are not social capital; the concept refers instead to the individuals ability to mobilize them on demand"
} 
social relations, established between people in specific locations. After all, the occurrence of global activities is contingent on social actors acting in a concrete space. In this way: Local sites of global processes do matter. The social construction of "place" is still a process of local meaning making, territorial specificity, juridical control, and economic development, however complexly articulated these localities become in transnational economic, political, and cultural flows (Smith \& Guarnizo, 1998).

Reaffirming that the state has not withered away, but rather continues to plays a critical role in mediating the flows of relations- local, international, global, and transnational.

Further, transnational practices are not simply embedded in specific social relations- the local; instead, they are grounded in the trans-local. Transnational interactions are not just about non-state actors accessing the global from home, more precisely; they are also about the connections forged from one location to another- from the local to the local. As Smith and Guarnizo (1998) point out, "transnational relations are constituted within historically and geographically specific points of origin and migration established by trans-migrants" (p. 13).

In the case of Jamaica, a rich history of contraband trade between Jamaica and Central America, as well as between Jamaica, the U.S., and European markets reveals the local embeddedness of transnational relations as it relates to illegal activities. The links, trade routes, and alliances established in the $18^{\text {th }}$ century ${ }^{25}$ seemed to also have played a

\footnotetext{
${ }^{25}$ Macleod, M. J. (2007). Spanish Central America: A socioeconomic history, 1520-1720. University of texas Press. Contraband trade between Central Americans and the British colonies in Central America and Jamaica were established, primarily through trade routes connected to the port of Trujillo in Honduras. Being the closest large island to the Gulf of Honduras, and hence Central America, Jamaica played an integral role in the Spanish contraband trade. The country helped to lower smuggling risks by providing
} 
role in the marketing and distribution of cannabis in the 1950's and subsequently of cocaine and guns in the 1980's. The introduction of higglers to the local Jamaican economy has also established local centers of distribution for legal and illegal goods, and has contributed to a high level of acceptance for illegal markets in the local economy. ${ }^{26}$ These relationships challenge the legitimacy of the state and its ability to clamp down on illegal economic activities that compete with the legal business environment. Further, the fluid nature of market conditions, shifting state policies, changing demands for goods and services, as well as migration flows, reinforce the need for enhanced transnational connections that are based on shared interests, predictability, and trust (Smith R. C., 1998).

Endurance and reproduction of transnational networks: Migration is often times the most effective means of transnational networks forming enduring interpersonal relationships across scales of interactions [individual, communities, institutionalized organizations], as well as across territories. Migrant groups and communities are able to construct transnational localities (Smith R. C., 1998) forged along multiple memberships to states, identities, and communities. They are better able to reproduce social capital based not just on mutual interests but also on shared norms and a combination of weak and strong ties (Arias 2006). Historically, Jamaica has experienced high levels of

\footnotetext{
storage for contraband goods from Central America until faster boats arrived to take the good to countries in Northwestern Europe. It also provides storage in bulk to Spanish America before they were exported to various markets.

${ }^{26}$ Brown-Glaude, \& Winnifred. (2010, November 7). Jamaican Higglers:...Time for A New Story. The Gleaner. Deteriorating and fluctuating economic conditions in Jamaica have further created a greater space for higglers and the expansion of the informal, underground and illicit economies; Chevannes, B. (2001). Crime and Drug-Related Issues in Jamaica. Souls: A critical journal of black politics, culture and society, 3 (4). Forever the middlemen of trade, higglers are able to profit from the sale of both licit and illicit goods. Such was the case in the 1950's when cannabis was sold in local markets by higglers specializing in bush medicine, teas, and roots.
} 
migration associated with labor from as far back as the late $19^{\text {th }}$ century. The high levels of migration tied to labor is not to say however that the country has not experienced other forms of migration such a social and political. In fact, the migration that did occur in the 1980's was mainly in response to political violence and the dispersing of politically affiliated gangs fleeing the country after the 1980 elections.

The early beginnings of the liberalization of trade, local markets and finance allowed for a thriving transnational community. Migration to and from Jamaica is a fluid process that involved multiple trips back and forth with individuals working and living between multiple locations. Access to better employment and lifestyle has allowed transnational communities in the U.S, Canada, and the United Kingdom to provide economic, political, and social flows between countries, whether through legal or criminal means. The fluidity of movement among Jamaican migrants compliments the flow of drugs to and from Jamaica, and the growth of organized criminal networks (Sives, 2010, pp. 133-137).

\section{Summary}

Chapter 3 asserts that a proper analysis of counter-hegemonic groups residing within the garrisons of Jamaica begins with an understanding of the concept of transnationalism distinct from globalization. Where globalization focuses on processes of deterritorialization and is too broad a term to correctly apply to the current study, transnationalization and its focus on territorial components provide the ideal lens through which to explore the dynamics between state and non-state actors within Jamaica. Transnational processes allow for a better understanding of the changing power dynamics of garrisons. A dynamic that is based on multiple and varied interactions that are 
anchored to specific localities and actors as well as, trans-locally- across and between different localities 


\section{CHAPTER 4}

\section{FROM GANGS TO GARRISONS: 1940s to 1970s}

The timing and consolidation of Jamaica's urban slums coincided with the economic hardships that took place in the 1970s and with the structural adjustment policies of the 1980s. The convergence of domestic and international influences initiated a prolonged period of upheaval that contributed to a reproduction of poverty within Kingston's urban communities. Because of overcrowding and increased poverty, several urban communities found themselves overflowing with the unemployed and the marginalized. Evolving into slums, these urban communities became impoverished, neglected, or otherwise disadvantaged area(s) of the city faced with a significant and disproportionately large amount of crime and violence, and the rapid increases in the emergence of urban youth gangs.

In an attempt to solve their problems of overcrowding and poverty, urban slums further redefined themselves as garrisons; aligning communities alongside political parties allowed residents access to scarce resources such as jobs and housing. As such, urban youth gangs have been absorbed into the garrison identity. These criminal entities have first taken on a political identity and second they have either, refined their organizational interests beyond day-to-day goals or, they have transitioned into larger more organized criminal groups that more distinctly carry out criminal activities between communities and across countries. This has created a complex melding of several of the characteristics and features that clearly distinguish between gangs, urban slums, and garrisons. 


\section{Understanding Kingston's Gangs}

In 1927, a prominent sociologist and one of several scholars conducting research on gangs observed:

An interstitial group originally formed spontaneously and then integrated through conflict. The following types of behavior characterize it: meeting face-to-face, milling, movement through space as a unit, conflict, and planning. The result of this collective behavior is the development of tradition, unreflective internal structure, esprit de corps, solidarity, morale, group awareness, and attachment to a local territory (Thrasher cited Rodgers, 1999; Thrasher, 2000).

Gangs were created in the cracks of society and as a means of filling the vacuum where the formal mainstream social institutions fell short in meeting basic needs. Influenced by its membership, some scholars hypothesized that gangs were temporary organizations comprised of individuals who were often ignored or left out of society. Gang members, so the literature argued, were typically youths in transition from one identity to another. Over time, other scholars (Klein, 1971; Cartwright, Tomson, \& Schwartz, 1975; Miller, 1980; Vigil, 1988) observed elements of delinquency, organization, violence, and increasing criminal activity. Gangs were something more than simply temporary adolescent groups of youngsters in their neighborhoods. What distinguished gangs from other juvenile groups was a clear association with criminal activity as a distinctive part of their formation (Rodgers, 1999). Gang members also acknowledged that they were a part of a denotable group, and were willingly involved in a range of delinquent activities (Klein, 1971, p. 13). The supposed temporary quality of 
gangs gave way to an appreciation of enduring socio-psychological bonds among members (Rodgers, 1999). These gangs met regularly face to face and are:

Bound together by mutual interests, with identifiable leadership, well-defined lines of authority and other organizational features. [This allowed them to] act in concert to achieve a specific purpose or purposes which generally include conduct of illegal activity and control over a particular territory, facility, or type of enterprise (Miller, 1980, p. 121).

Research continued to reveal (Taylor, 1990) a plethora of gang categories including highly organized structures that became institutionalized. Gangs also constitute a variety of member types. They contain not just youths but also veterans; they are also comprised of core members and leaders, as well as peripheral members (Klein, 1995). These distinctions suggest that members are able to participate in a wide variety of gang activities and often are awarded varying levels of status within the gang, though not always voluntarily. Primarily an urban phenomenon, gang members generally come from a low-income socioeconomic background. As a result, the age of the average member of a youth gang is determined more by sociocultural factors than by an actual age (Rodgers, 1999). If members have not become victims of gang related violence, it is common for older members to 'mature out' of the gang. " A significant share of youth gang members will turn to full-time criminality, either as members of an adult gang or individually" (Rodgers, 1999, p. 4).

It is not uncommon for adult gangs are larger to aid, and/or become more regionally and/or internationally structured organizations that outsource local criminal activities to these urban gangs, and utilize them as potential membership recruiting pools. 
As a result, rather than declining as its peer group matures, urban gangs can persist over generations despite leadership changes. Many gangs are sometimes able to evolve into an organization structure to 1) sustain multiple roles of members, 2) to adapt to changing environments without dissolving to attain goals, and 3) to organize a distinct outlook of its members.

Although community residents perceive gangs as distinct groupings characterized by criminal activities, the interactions between these members of the community and the gang are not always contentious ones. These communities often are caught up negatively in the rivalries and boundary wars between rival gangs as their leaders impose invisible boundaries that restrict not just gang members but also community members from crossing. ${ }^{27}$ Further, the severity, with which these borders are maintained, is often seen in the death of women and children from the various communities that mistakenly ventures into the no-go zones (Reid, 2010). However, it is not uncommon for gangs and communities to typically develop a working relation on the basis of mutual aid and respect" (Rodgers, 1999, p. 3; Zatz \& Portillos, 2000; Horowitz, 1987). Primarily because they reside within the communities, gang members are able to forge community ties that extend beyond their gang identity. Community gangs in many cases ensure that interactions taking place within the community are violence free, that reprisal killings are carried out for the community, and that the community inhabitants and their property are

${ }^{27}$ Reid, T. (2010, February 7). Boodshed on the Border: Women, children murdered across enemy lines. Retrieved September 22, 2013, from The Gleaner: jamaica-gleaner.com/gleaner/20100207/lead/lead1.html Refers to this as the "borderline culture." 
generally protected from other gangs. In return, communities informally legitimize the gang and protect their identities from law enforcement (Harriott, 2004).

The case of Jamaica: In the case of Jamaica as Rodgers (1999) points out, the majority of the research on gangs and garrisons has tended to focus on the more infamously recognized criminal organizations known as yardies and posses. Distinctly different from the concept of the local gang, these entities are comprised of adult based members that carry out a wider range of criminal and increasingly violent activities. These organizations typically operate transnationally as well as domestically, and are primarily concerned with the forging of commercial and economic linkages. Both types of gangs are prevalent within the urban areas of the country's capital.

The Jamaican state currently is faced with the challenge of dismantling approximately 268 active gangs, $74 \%$ of which can be found in the country's urban communities (StabroekNews, 2010; Ramsey, 2012). In order to explain such a high number and to provide an accurate analysis of gangs in Jamaica, the time-period of the 1940's through the 1970's proves most important. That is because it demonstrates the growth, development, and response of disenfranchised segments of the population, whose survival more than any other group in society are consistently affected by changes in the social, economic and political conditions of the state. More specifically, the time-period allows for an analysis of how pressures from the international system, influenced views of the gangs by the Jamaican political system both pre and post independence. It also examines changing Jamaican state capacity from a crown colony state of Britain during the early 1940's to a newly independent state in the 1970's. 


\section{Gang Formation within the Context of Politics}

The political climate of Crown Colony Rule: The precursors for change in the political structure of Jamaica took shape before the period in which Jamaica became a Crown Colony of Britain and evolved within the context of the Great Depression and its aftermath. Concerned with early attempts of rebellion ${ }^{28}$ in 1866 , the British strengthened their control of Jamaica by switching from a colonial representative assembly to a Crown Colony of Britain with limited representation. Under this system, political rights were removed completely from the island inhabitants putting an end to local governments. Under the new system, political control was now reserved only for officials directly appointed by Britain. Within the context of the Great Depression and its aftermath, the tightening of political power over the island only contributed to a growing desire for political and social change among specific elements of the Jamaican population.

As with many other countries within the international system the Great Depression revealed the weakness of Jamaica's local economy and the larger more endemic problems in the structure of the economic interdependence established between Jamaica and the Crown. Jamaica experienced a decline in the price of its main export product sugar and simultaneous increases in its standard of living. A weak economy and poor trade combined with a reduction in wages and unemployment and economic stagnation quickly followed suit. A significant number of lower class Jamaicans who had left the island in search of economic and social advancement returned home as the international system collectively experienced the consequences of constricted economies. Jamaican migrants faced increasingly restrictive immigration policies and quota laws in

\footnotetext{
${ }^{28}$ Morant Bay Rebellion October 1985
} 
countries like the United States. They also experienced the end of large construction projects like the Panama Canal and they saw the close of agricultural programs in Latin America that no longer guaranteed employment. Jamaicans quickly returned home contributing to an already rising unemployment rate. Returning residents settled into the country's urban areas adding to the growing number of citizens who were moving from the countryside to the city in search of jobs. Jamaica's agricultural sector closed factories, laid off workers, and in some cases switched to banana production. Although the banana industry was shaped later by the depression economy, it also directly contributed to rising unemployment as its production methods were less labor intensive than sugar; closing factories, laying off workers, and switching industries were all attempts to help the agricultural sector remain viable (Roberts, Powell, Sinclair, Boland, \& Hewitt, 1974).

With the tightening of jobs in the rural areas, many residents flocked to the city in search of employment. The swelling of urban areas and the spread of poor living conditions were specific to certain areas of the city. As Munroe (1972) points out, during this period:

Historically, culturally, and institutionally Jamaica was split into distinctive patterns of behavior, associations and, through to a lesser extend, values. Color and class coincided in a hierarchical continuum evident in both town and country. Social good accrued to each color-class section in inverse relation to their numerical preponderance in the society. (p. 5)

Of the 1.2 million inhabitants on the island in 1943 , the racial composition was such that approximately one percent was white, 18 percent were brown or colored, and 78 percent were black; an additional 4.8 percent was classified as East Indian, Chinese and Other 
(Roberts G. W., 1957, p. 65). Racial composition also revealed an established pattern of living based on race and class. In 1943, approximately 84 percent of all blacks resided within the rural areas versus the 70 percent of Whites located in the Corporate Area (Roberts G. W., 1957, p. 67). ${ }^{29}$ The imbalance was clearly a result of the legacy of slavery. Rural areas were once firmly tied to the plantation, post slavery these areas remained the primary means of employment for the freed masses. The droves of individuals moving from the countryside to the city soon altered the established socialeconomic makeup of urban areas. The influx of individuals moving from the countryside to the city consisted of a workforce that was primarily black, unskilled, semiskilled, minimally educated, and marginally paid. Within the city, this growing 'potential' workforce found employment in low wage jobs in the service industry such as domestic servants, petty traders, dockworkers, and street cleaners. With so many people chasing low paying and limited employment, high density slums such as Smith Village became a common occurrence is western sections of the city.

As University of the West Indies Lecturer and Gleaner Columnist Robert Buddan (Interview July 19, 2012) explains, employment opportunities in the international system became choked off in the 1930s resulting from the Great Depression in the United States. Cuba and Puerto Rico suspended immigration for Jamaicans for stimulating increasing rural migration to West Kingston in search of employment. "Rural to urban patterns of migration is pretty universal. People move from poorer areas where there are less jobs and income to areas with better opportunities, but in the process depending upon national and local circumstances the struggle is different for different groups and different for how

\footnotetext{
${ }^{29}$ Includes the Capital city Kingston and the surrounding suburban area of St Andrew
} 
these groups are integrated into the party and electoral system". Low pay and high levels of unemployment fueled a series of riots that revealed the social and economic unrest prevalent not just in Jamaica in the 1930's, but most notable within other British colonies such as Guyana, Trinidad and Tobago, and Barbados.

Riots of 1938: Significant in the case of Jamaica were the Riots of 1938. It was the second time in the country's history that massive riots had led to any significant change in the political framework of the Jamaican state. Similar to the riots that sparked the transition to Crown Colony rule, the Riots of 1938 prompted a modification in the Crown Colony system in 1944 allowing for limited self-government. Although the governor retained veto power, the new constitution allowed for a return to representative government after roughly eight years.

What makes these political changes even more significant is that by incorporating universal adult suffrage into the 1944 modifications, the Riots of 1938 had inadvertently pushed for the formal convergence of society and politics. "Previous to the 1940s, the constitutional order snubbed the social mass and visa versa; meetings had been infrequent, informal, and traumatic. After 1944, a marriage of principle and expediency enforced regular interaction" (Munroe, 1997, p. 1). The black masses had always been excluded from the political process, and although the riots fueled political change, they did not result in expanding representative government. Further, the increasing levels of unemployment throughout the island during this period intensified social discontent that was primarily an economic one. Social and political factors for the most part remained constant, as economic factors continued to deteriorate (Bertam, 2006, para. 14). 
With the restoration of preferential pricing in the sugar industry and the construction of a new and more modern factory in 1938 large segments of the unemployed travelled to the Frome Sugar factory in search of jobs. Despite a growing anticipation of an increase in wages, the high demand for employment drove down the actual wages offered by the sugar factory (Bertram 2006). The factory's response to the high labor demand reinforced a national wage rate that had been unchanged for over a century. Sparked by disgruntled sugar workers refusing to accept the low wages, the news of the riots quickly spread to the urban areas. Dockworkers and street cleaners promptly followed suit while municipal workers, food and transportation workers, and the unemployed later joined them. Aware of their historic exclusion from politics and accepting that help would not come from the government, the black masses rioted out of concern over their "struggle for land ownership, better wages, and descent living conditions" (Williams E. E., 1969, p. 85).

Within a short timeframe, what had began as a small labor strike had manifested into an island wide series of protests. Demonstrations in Kingston brought businesses to a halt as several businesses closed their doors in response to the protests. Demonstrations spread through the countryside and within a week, every parish reported strikes and arrests (Hart, 2002, para. 10-11). The Frome Labour Riots ended with the death of 14 individuals and another 180 persons injured (Hart, 2002). Prominent Caribbean jurist, and president of the International Tribunal for the former Yugoslavia, Judge Patrick Robinson argues that the Frome Labour Riots represent the final of three pivotal events that: 
provided the furnace in which our independence was forged. In Sam Sharpe's

Christmas Rebellion of 1831, over 500 persons were killed; in the 1865 Morant

Bay Rebellion, some 400 persons were killed. In the most recent of these events, the 1938 Labour Strikes, some 15 persons were reported as killed. These deaths resulted from action taken by the colonial government to protect what it considered Jamaica's national interests, which of course meant the interests of Britain.

The aftermath of the Frome Labour Riots was not the worse outcome associated with the Jamaican state's defense of its interests against a segment of its population, however, it was an important catalyst for changing the social contract formed between the state and the population—driving the state towards independence in 1962.

Constitutional Decolonization: The widespread disinterest in political mobilization by the black masses did not however mean that Coloreds' and Blacks' were prevented from securing political posts. Despite a political system constructed around White leadership, a handful of Brown/Colored and Black individuals did manage to hold seats in the Old Assembly under local representation and under Crown Colony through appointed elections (Munroe, 1972). ${ }^{30}$ However among the Colored, realizations that "limited upward social mobility was possible for non-white with improvements in his economic circumstances...[meant that this emerging group of]...local legislators wanted

\footnotetext{
${ }^{30}$ Munroe, T. (1972). The Politics of Constitutional Decolonization: Jamaica 1944-62. Institute of Social and Economic Research, University of the West Indies. "Mullattoes had held seats in the old assembly and increasingly brown professionals gained election to the reformed legislative council. Their growing numbers despite static restrictive property requirements for membership merely indicated that class color correlates were neither absolute nor caste-like....By 1910 there were 5 colored and one negro among the 14 elected members"
} 
greater power for their class rather than a broadening of the bases of the political order" (Munroe, 1972, p. 14-16). Despite the dilution of Whites wielding political power, the assimilation of the Colored into the political structure initially guaranteed consensus in ideas, interests and expectations.

For the even smaller handful of Black officials, several factors warded off any interest they might have had in trying to mobilize along a wide political base. First, there was a lack of collective support among the other racial groupings, and a lack of desire for it within the black masses. Second, there were lessons to be learned from how colonial authorities responded to the growth of reform movements such as the Bedwardite Movement ${ }^{31}$ and later Marcus Garvey's Pan-Africanism ${ }^{32}$ between the 1880s and 1930s.

In the case of the Bewardite movement, as its leadership grew more powerful and its religious message translated into a political threat to the established order, colonial authorities used vagrancy laws to arrest black activists. Who they branded as delusional and insane. The movement's leader committed to an insane asylum where he later died (Price, 2009, p. 46). Similarly, during 1927-1935 when Garvey formed a political party and became more involved in Jamaican politics, he was blocked from participation and subsequently imprisoned (Shakes, 2009).

\footnotetext{
${ }^{31}$ Price, C. (2009). Becoming Rasta: Origins of rastafari identity in Jamaica. New York, New York: NYU Press. Bedwardite movement was a religious movement based within the urban slums and spanning across the island. The movement consisted of small farmers, casual and household workers, higglers, craft workers, and the unemployed, and promoted the ideology of black ownership of land and the need for black leadership within political institutions such as the court of laws to ensure justice. This movement also declared the rising of black power, and resulted in frequent classes between his followers and the colonial authorities.

${ }^{32}$ Ibid. pp. 45-46. Marcus Garvey, "internationalized his idea of black uplift and unification so in doing so held out new ideas for interpreting blackness. Unlike Bedward who spoke exclusively to rural residents and the disposed, Garvey's message took hold among urbanites and Jamaica's Black petit bourgeoisie."
} 
As to be expected having sparingly been exposed to power, the emerging Colored and Black middle class increasingly desired a larger share in the political order. At first, they tempered their interests behind professional interest groups such as, the Jamaican Union of Teachers (1894) and the Jamaica Agricultural Society (1895). These organizations did not challenge the status quo and maintained the expectations of the ruling few. However, there was a growth in the number of reform organizations pushing for the widening of the constitutional order to accommodate the growing interests of this new class. ${ }^{33}$ "They varied in their aims and influence, but all of these groups reflected frustration with the economic, social, and political restraints that the colonial system placed upon the aspiring colored or black middle class" (Bakan, 1990, p. 99). When the Frome Riots broke out, Munroe (1972) argues that the initial reaction of the middle class was to restore order. Similarly, Bakan (1990) asserts that the initial intent of these organizations was to push for moderate constitutional reform. However, they quickly interpreted the riots as actual proof that more radical were needed reforms pushing the country towards ideas of a national government. The middle class sought to use the physical number of the masses to fuel the drive for nationalism.

The face of popular leadership: By the end of 1938 two distinct leaders had emerged from the middle class promising to advance the cause of the working class. Although they came from the same socio-economic grouping, Alexander Bustamante and Norman Manley both represented two distinct middle class views and leadership styles. Manley perceived the riots as an example of the growing self-determination growing

\footnotetext{
${ }^{33}$ Munroe, T. (1972). The Politics of Constitutional Decolonization: Jamaica 1944-62. Institute of Social and Economic Research, University of the West Indies page 21. Reform Organizations such as: Jamaica Progressive League 1936, National Reform Association, the Federation of Citizens Associations and the weekly paper Public Opinion started in 1937.
} 
among local inhabitants. He was primarily interested with access to state power and the enabling of political rights for the masses. In a few months after the 1938 riots, Manley established the People's National Party (PNP). The more liberal sectors of the middle class as well as the Jamaican business classes supported his ideology. The membership of the PNP was characterized as primarily urban, educated, propertied, and made up of professionals such as lawyers, doctors, and teachers.

Similarly inspired by the momentum of the riots, Bustamante differed from Manley by focusing on increasing labor power and in establishing a national base for the many trade unions he had established following the Riots of 1938. Characterized as a populist leader and voice of the workers movement, Bustamante was backed mostly by conservative businessmen within the middle class, the lower classes, and unskilled labor. He eventually formed the Bustamante Industrial Trade Union (BITU) and later the Jamaican Labor Party (JLP) in 1943. Not giving up without a fight, the Whites tried to protect their business and commercial interest by forming the Jamaican Democratic Party whose platform called for policies of free enterprise. Lacking a wider support base, The Jamaica Democratic Party received miniscule votes during the 1944 elections and disbanded soon after.

During the period after the Riots of 1938 and leading up to the 1944 elections, the PNP played an integral role in pressuring the Colonial powers for a more serious constitutional reforms with the objective being self-government. The PNP attempted to broaden its political base to include the working class as well as rural sections of the country. The party's ideology as revealed in Manley's negotiation agenda during the Riots of 38 (Munroe, 1972, p. 22) sought to advance change by first redirecting the fervor 
of the masses from violent protest to support for party goals; and secondly, by strengthening colonial support for self-government by generating confidence in the party's ability to control the masses. Yet, the masses maintained their suspicions of politics and of the middle class even though the PNP represented a national "voice of moderation". Not only was Manley a member of the middle class, and a lawyer, he had historically maintained a professional relationship with the ruling oligarchy while at times representing their business interests (Munroe, 1972, p. 24).

During that same period, Bustamante focused on strengthening his labor movement. He positioned himself as the voice of the working class and became a public speaker for the rights of the workers, strengthening a once weak labor movement "the fight has begun for more pay. We are going to organize the entire Jamaican Labour into one Union” (Brown, 1974, p. 211). As a member of the middle class, Bustamante was also rebuffed initially by the masses. His persistent involvement and leadership in the labor protests and marches, allowed him to transition into the role of the "labour leader" and the founder of the BITU. This role was cemented further by the established order when on several occasions they imprisoned Bustamante for his involvement in disruptive activities. As Wynter (Ctd in Brown 1974) points out:

He began to take charge, to lead the marches, to organize the meetings, to fire defiance and challenges at the old order that kept the crows roaring in a fervor of emotional release; that cemented once and for all a bond between leader and followers that was stronger than any other bond that bound the majority of the masses to the Government of the colony, from whom they now withdrew the 
dumb and passive allegiance that they had been intimidated by fear, habit and custom into giving- for so long and for so little. (p. 206)

Manley \& Nettleford (1971) most clearly identified the root of the ideological difference between the two leaders when he wrote; "the truth is, Manley's concern with self government was at the expense of labor's immediate concrete problems. For [Manley], self government had to precede the quest of social justice" (p. 381)

Rather than forging a united national front, the two popular leaders formed an uneasy alliance that combined the advantages of the PNP's party organization with that of the BITU's mass support. However, this alliance was disbanded shortly on the grounds of distrust and deceit; leading to reemphasizing differences based on class and race.

In the wake of the Moyne Commission recommendations for constitutional reform with limited self-rule, Bustamante quickly formed the JLP in 1943 and a rivalry for popular control between the two leaders began. Recognizing that PNP membership was primarily urban and located within the hub of national politics, Bustamante strategically sought to represent the urban workers located within the capital's western areas. The Western area of the city consisted of communities overflowing with rural to urban migrants in search of employment. Bustamante's message of social justice spoke volumes among these communities that had previously been characterized as consisting of the unskilled, semiskilled, the minimally educated and the marginally paid. As Kingston began to experience rapid urbanization and population growth, the plight of these communities and its residents within them increased. 
Given the population density in the rural areas and the membership of the BITU and the JLP, the party was already in prime position to win a large number of seats in the House of Representatives. However, by finding a place within the urban communities, Bustamante had been able to win the vote needed to ensure victory. His charismatic personality and his drive for social justice helped him to win "almost 70 percent of the votes cast in the completely working class area of Western Kingston" (Munroe, 1972, p. 43).

By the second national election in 1949, the PNP had managed to align with the urban machinery of the Trade Union Congress (TUC). In that election the PNP was able to win the popular vote, but was still not able to win control of the government, as it was not able to gather a large enough rural voting base.

Gang formation in the 1940's: Gang formation in the 1940's is tied to the failure of the Crown Colony state to follow through on promises of social reform. As both the JLP and the PNP evolved into more established political parties, a process of constitution and institution building began that aimed at taking the country towards full independence. However, under limited representation both parties refused to find a common ground aside from a desire for independent rule. Disputes between both parties and their affiliated institutions increased. Eventually a number of gangs including the Group of 69, the Vikings, the Skulls, the Phoenix City, Phantom, and the Spanglers (Gray, 2003) worked with both political parties to rally against each other and to protest against poor wages, poor working conditions, rising unemployment, and social and political injustices. Mogensen (2003), a member of the international organization Children in Organized Armed Violence (COAV), and a scholar on gangs in inner city Jamaica emphasizes: 
The division of inner city neighborhoods according to political allegiance occurred in the 1940s and 1950s with party supporters choosing to live together in certain sections (yards) and rival party supporters forced out of others. This segregation of certain areas occurred some twenty years before the creating of politically controlled housing schemes (Harriott, ctd. in Mogensen, 2003, p. 229)

Although Jamaican gangs carried out political acts, it is important to point out that at this period in time these gangs had yet to embrace a political identity. Before the mid50s, Jamaican gangs largely confined their activities to petty theft, violent turf rivalries, and sporting competition in soccer matches (Gray, 2004). The forging of a political identity did not take place until the state created a legal space for politicized urban areas in the 1960 's. ${ }^{34}$ As a result, these urban gangs are best understood as organized groups utilized by the two dominant political parties, in order, to collectively challenge the colonial status quo and to secure each party's place in the drive for independence. The political machinery within both political parties viewed the use of violence and gangs as a viable and acceptable means to obtain political objectives as part of an institutionalization of gangs in Jamaica's urban political environments.

Given the context of forging state identities, securing loyalties, and managing economic development the relationship between the new state and organized gangs began to change with independence in 1962 . No longer were these organized groups simply

\footnotetext{
${ }^{34}$ Gray, O. (2004). Demeaned Empowered: The Social Power of the Urban Poor In Jamaica. Kingston, Jamaica: University of the West Indies Press page 75. "By the mid 1960s [the gangs'] role in street and constituency level political violence in West Kingston was unmistakable. The Phoenix City gang, for example, had sided openly with Edward Seaga and the cause of the JLP. In their turn the Rastafarian and socialist leaning Vikings gang defended the right to their own turf and the PNP's Control of precincts in West Kingston”
} 
mutual co-conspirators with the anti-colonial leaders collectively challenging the status quo in a Crown Colony. Now these urban gangs were seen as challengers to the new state. As such, gangs adopted a political identity that was consolidated with the state in the form of territorially located garrisons. Clarke (2006b) observation this consolidation of the state and the garrison when he states; "in the last [34] years, the JLP has never had fewer than two Kingston seats and the PNP never less than six (except in 1983). ${ }^{35}$ The enduring bailiwicks may be attributed to the development of garrison communities in downtown Kingston" (p. 429).

Rather than primarily drawing support from among the lower classes in the urban areas, both the PNP and the JLP used nation building as a means of connecting with the population as a whole. "After their initial period of division, the two major political parties had become increasingly indistinguishable" (Bakan, 1990, p. 135). Having learned its lesson from the first election, the PNP had began to linked itself to several urban trade unions and had also began to seriously expand its power to areas outside of the city. There was a new focus was on creating a distinct political ideology and a collective sense of culture that would fuel a loyalty to the nation-state that went beyond tangible incentives and that addressed the deeper concept of self.

\section{Gangs within the context of the Economy}

In addition to the political context, gang formation is tied also to limited industrialization in Jamaica under Crown Colony rule followed immediately by a period of rapid industrialization beginning in the late 1950s and early 1960s. Jamaica's drive

\footnotetext{
${ }^{35}$ In 1983, the PNP boycotted the general election questioning the voter registration process and the implementation of anti fraud measures.
} 
towards industrial growth was limited primarily by the colonial policies that were implemented during the Great Depression through World War II (Bernal, 1988). In relation to other countries within Latin America during that same timeframe, limited development quickly evolved into late development as Jamaica, unlike its counterparts, was not able to dedicate any real focus to this endeavor until after it had attained independence in 1962.

By the 1930s, the impact of the Great Depression was causing a wave of reductions in export earnings that subsequently limited the import capacity of several states. Different from China, Korea and Taiwan where rapid development was tied to powerful manufacturing exports and vast inflows of foreign capital, countries like Chile, Mexico, Brazil, and Argentina had switched focus to import substitution industrialization. These countries developed domestic markets around their primary export products, as well as around products that could be manufactured successfully by substituting for local materials. In Jamaica, the story goes a little differently.

The 'Imperial Vision' was of a center-periphery international division of labor in which the British supplied manufacturing goods in exchange for primary products and raw materials from the empire. This was to be operationalized by a mercantilist system of trade preferences and the 'sterling exchange standard' in which the 'natural' complimentary of British capital and skilled labor would integrate with land and unskilled labor of the Empire (Bernel, 1988, p. 7).

Although facing the same reductions in its exports and despite the various nationalist groups that called for home grown industrialization at different periods, the Colonial Authorities remained firm. Proponents of Garveyism called for legal support for the 
development of native industries from as early as the start of the great depression. Shortly after the Riots of 1938 the first of many calls for local industries were voiced by the newly established PNP. However, the Colonial Order opted to serve their self-interests by ignoring calls for expanding the industrial sector, as well as by suppressing the growing discontent among the masses. In light of the Riots of 1938, the Colonial authorities responded by pumping a significant amount of funding into social welfare projects and to the development of the agricultural sector. "In Jamaica the Ten-Year Development Plan of 1946 allocated 31 percent of expenditures to agriculture and only 2 percent for trade and industry" (Dutt, ctd in Bernal, 1988, p. 8).

Yet, Britain's “Imperial Vision' was also a victim of circumstances. The British Empire aspired to recover financially from World War I while faced with staggering war time loans from the United States, all within the climate of the Great Depression. Jamaica was not cushioned from the effects of a decline in the price of its main export products. The increases in its standard of living, and the reductions in wages and unemployment that followed suit were compounded by the increasing rural to urban migration, as a result of declines in export goods and by the return of residents from abroad. The undeveloped industry that was in existence in the urban areas did little good in placing the excess labor that poured into Western sections of the city into the work force; this lead to high unemployment rates and to communities that turned into squatter settlements.

Given the complications with the sugar industry, the government came to play a strong role in the economy, pushing for large macroeconomic planning and rapid industrialization. During the same time, there was an upturn in the economic conditions 
on the island. World War II increased trade to Britain, providing it with food and raw materials during the war. The island also discovered bauxite and alumina, and by 1952, it began commercial production. By the 1960's, tourism was also included as a major source of revenue to the island. Following the Puerto Rican growth model of development, the government opted for industrialization by invitation. Large foreign corporations were offered generous fiscal incentives and were invited to invest in Jamaica. This overarching view of development lead to a further influx of rural to urban migration and the over-fill of urban communities filled with the unemployed and the minimally educated. As Lacey (1977) pointed out, the economic history of Jamaican has always been about the story of "too many people chasing too few jobs" (p.7). Further, the unbalanced population structure because of emigration and the rapid increase in the rate of urbanization by youths, further contributed to the structure of potential labor force (Lacey, 1977). 


\section{Summary}

Jamaica is a prime example of how urbanization in the developing world is often times unconnected from industrialization and even development. Despite a delay in development, swelling garrison communities often overflowed into redefined zones. “" 'Overurbanization,' in other words, is driven by the reproduction of poverty, not the supply of jobs....and has been an inevitable recipe for the mass production of slums" (Davis, 2006, p.16-17). This trend of 'overurbanization,' is identified easily in Latin America- Brazil, Asia- Beijing, India-Mumbai, and Africa-Kenya. ${ }^{\mathbf{3 6}}$

Moving beyond the simple movement of rural- urban migration, Guldin (2001) also conceptualized urbanization as the 'urbanization of places.' That is, the degree to which characteristics that differentiate between various places that fall along a continuum of rural-urban, are no longer clearly distinct. Lifestyles, population sizes, territorial characteristics, and modes of production are no longer distinctly urban or rural. Guldin (2001), points to urbanization that is not clearly urban or rural, but rather a blending of the two. Rather, than new spaces, we see old spaces taking on new identities. Within this analysis, we find communities taking on this blurring of rural/urban development, and "becoming identified as polycentric urban systems without clear rural/urban boundaries" (Davis 2006, p. 10). Historic urban segregation with Jamaica's capital reveals that urban slums were formed at the heart of its commercial centers, close to jobs, while more affluent classes resided within the surrounding residential areas of St Andrew, as the city

\footnotetext{
${ }^{36}$ Davis, M. (2006). Planet of Slums. Verso, page 17 'OOut of necessity people turn to self-built shanties, informal rentals, pirate subdivisions or the sidewalks... unserved by established utilities and municipal transport, thus making 'urbanization' and 'favelization' synonymous."
} 
grew, slum areas expanded across the country near important new commercial centers. Some of these slums have evolved into garrison communities.

Still, a grounded insight into the transnational nature of the garrisons requires an understanding and the unpacking of the complex fusion between key features of early urban gangs and the area slums that originated within the urban areas of the country.

The current study posits that garrisons differ from simply impoverished areas in how they have originated, as well as, in how land appropriation and outward expansion takes place. Late colonial slum areas in West Kingston have been recognized from as early as 1935 and again in 1947 when it was noted that there was an influx in the number of urban communities in poor condition. The permanence of the slums was reinforced with the zoning of third-class housing in 1952, and the overcrowding districts and areas of poor housing that continued in the 1960's (Clarke, 2006a). Whereas the majority of urban slums are created because of the outflow of the rural poor to urban areas, garrisons primarily originated because of political factions among the poor.

From the very beginning, membership of the garrison requires a high degree of exclusivity. More than just inner city communities, garrisons also apply force within its communities in order to maintain consistent homogenous voting behavior and undeniable party support. Through its ties to the political party, garrison leaders are able to provide its members with rent-free housing, free access to utilities, and access to jobs. Individuals, in extreme cases, who reject the political choices made for them are either violently killed or their families killed as an example. 
Political factions that occur both within the garrisons and between garrison communities also affect land appropriation and outward expansion. In some cases, where individuals within a specific community rejects the political identity assigned to them by the garrison, they have few choices. They are either usually ostracized by the community and forced to either join other communities who share their political view and that are open to deflectors, or they form squatter and sometimes politically competing communities on the outskirts of the established garrisons.

In addition to being distinct from simply impoverished areas, garrisons also possess a divergent and staunch political identity that disqualifies garrisons from merely replicating gang identity. The key distinctions between a garrison and a gang is that where gangs are primarily fluid socializing organizations formed along the boundaries of society, garrisons are primarily politicized, and territorially defined communities that are comprised of gangs and impoverished individuals. Like the gang, the garrison is also a socializing agent that provides social and economic benefits to their members. Further, they are also responsive to rapidly changing or significantly altered social structures, specifically social changes that weaken or threaten their livelihood. The politicized nature of these communities, however, helps to construct a group identity that is not consistent with the typical gang identity; thus making the garrison unique in relation to the gang. 


\section{CHAPTER 5}

\section{A TYPOLOGY OF THE GARRISON AND IT'S TRANSNATIONAL NATURE}

This chapter focuses on the typologies and structures that define the Jamaica garrison within the Kingston Metropolitan Area (KMA). It explores how garrison typologies and structures are framed continuously by access to resources such as jobs, housing, and basic amenities within the KMA, as well as by the changing nature of global interactions. Ultimately, an exploration of how garrisons have found strategic ways to modify fixed territorial spaces, into blurry and fluid zones of control, help to reveal its transnational nature and to highlight the influence that its various makeups have on state decision-making.

\section{The Kingston Metropolitan Area (KMA)}

Compared to the rest of the Island, the KMA is an extremely dense urban space. It spans approximately 176 square miles and is an amalgamation of the parishes of Kingston and St. Andrew. With a 2011 census recorded population of 662,426 persons, the population density of the metropolitan area is 3,763 square miles, and accounts for $25 \%$ of the Country's population. The remaining $75 \%$ of the population resides within several other rural, suburban, and urban areas with a population density of only 502 square miles. ${ }^{37}$ In addition to a high population density, continuous urban growth, vital industries, several major transnational shipment points, and the location of garrisons also characterize the KMA.

\footnotetext{
${ }^{37}$ This figure does not account for areas throughout the country that are inhabitable
} 
Within the KMA, the parish of Kingston is home to the country's capital, which is also the parish's namesake. Home to the seventh largest natural harbor in the world, the city of Kingston from as early as 1703 was recognized as a primary commercial city. By 1872 replaced Spanish Town as the country's capital. The harbor allowed the city of Kingston to become the main transportation hub for both international and domestic trade. Government offices and ministries were transferred from the former capitalSpanish Town, and major state and private entities within the financial, industrial and commercial sectors followed suit. By the 1920's, the city housed the Jamaica Power and Light Company and two of its fossil fuel plants. The 1930's saw the construction of the Island's first airport, which became an international hub in the 1950s. The 1950's also marked the establishment of the Jamaica Cement Company. A company that exports its own mined gypsum and manufactured cement using its quarry and ports. 


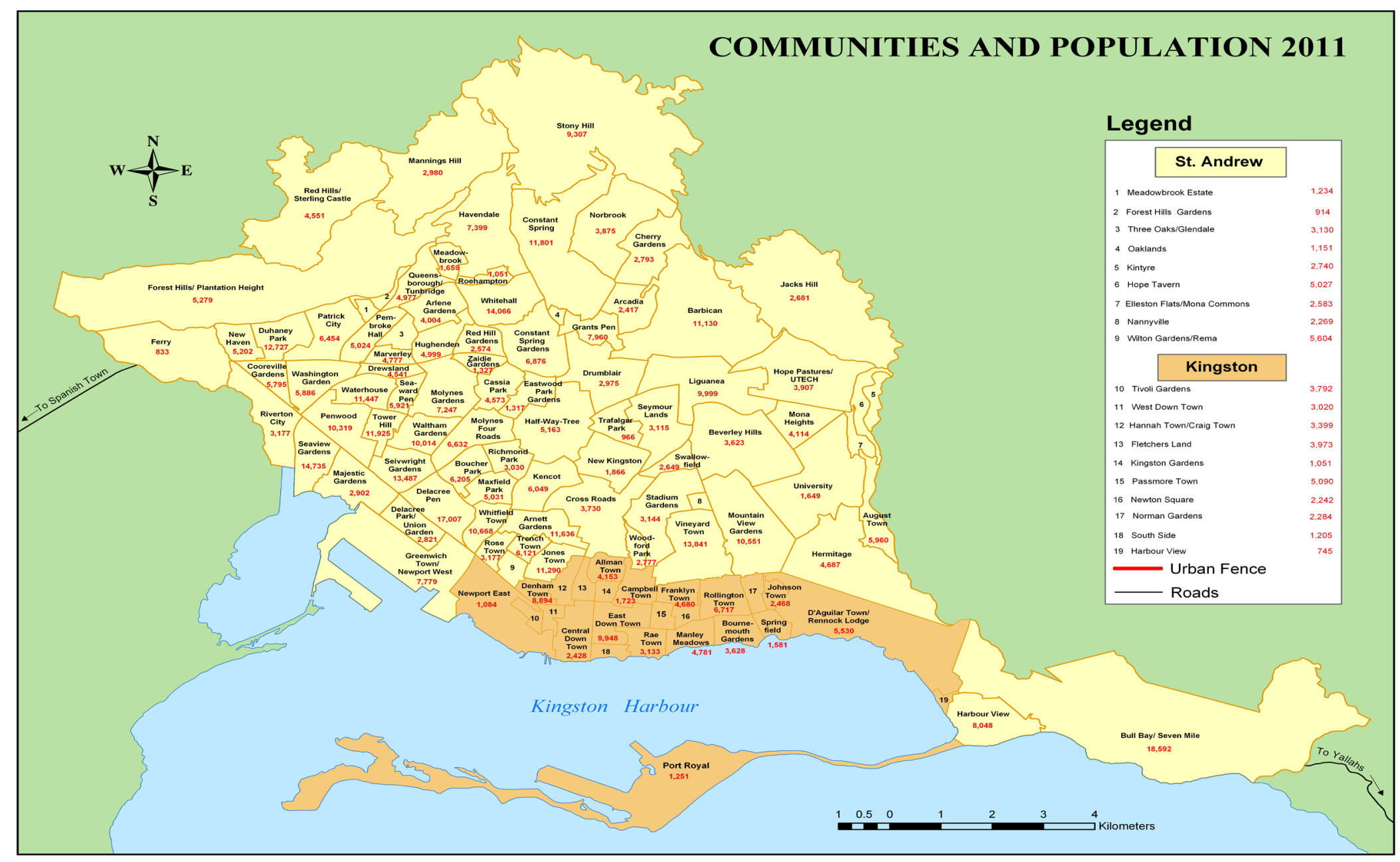

Figure 6. Kingston Metropolitan Area-Communities\& Population 2011

Taken from [STATINJA] 
As Kingston was being developed into a commercial and industrial hub, the initial population of the city was rapidly growing with a large "potential workforce" hoping to find employment. The original residents of the city were actually refugee survivors from a 1692 earthquake that destroyed Port Royal, once known as the "Wickedest City on Earth." Port Royal was known as a haven for pirates, and as the former mercantile center of the Caribbean- transporting both legal and illegal goods (Hamilton 2000). Reverse cycles of migration because of the great depression, rural to urban migration, as well as the politics of constitutional decolonization and its effect on economic development, all resulted in the establishing of permanent urban slums as large segments of the population came to the city in search of jobs.

By the 1960's, the government took ownership of the rail system that had been in place throughout the Island. The Jamaica Railway Association located in the city of Kingston, coordinated the transport of passengers, as well as sugar, banana, bauxite, and produce across the island and for export. During that same period, Kingston also housed the country's first oil refinery, ${ }^{38}$ an export-based flourmill, and a public hospital. Yet, the developments that were taking place in the industrial and transportation sectors could only provide so many jobs. There was still a heavy dependence on an inefficient agricultural sector and the manufacturing sector was still in its infancy.

Further, the restructuring of urban gangs along political lines in exchange for jobs and housing lead to increasing levels of crime and violence within the urban slums of West Kingston and its surrounding business district; making downtown Kingston an

\footnotetext{
${ }^{38}$ Esso Standard Oil built the first oil refinery on the Island in the mid 1960's. This refinery was later purchased by the government in 1982 and was renamed Petrojam.
} 
unstable business environment especially during election cycles. In an attempt to provide some stability, the government during the 1960s focused on the development of New Kingston, an area specifically designated as the financial center of the city, far removed from the violence of downtown Kingston. The dichotomy of the financial center from the commercial and industrial hub of West Kingston further reinforced the garrisonization of the urban slums by segregating class boundaries.

Whereas the parish of Kingston is mainly comprised of urban slums and is populated by low-income individuals in search of jobs, the parish of St. Andrew [which also makes up the KMA] is home to the city's wealthy. It is "situated in the suburbs to the northern section of Kingston, closer to the hills and Mountains of the Blue Mountain range. [With the new financial and shopping district close by], the functions of the wealthy are met within the New Kingston area" (Nicolas, 2003), and eliminated the need for viable businesses to be located downtown. As the manufacturing sector expanded and diversified into a wide range of products, ${ }^{39}$ the need for a large labor force also grew, but the majority of businesses within the manufacturing industry chose to locate themselves outside of Downtown Kingston and its surrounding areas. Rather, they tended to remain

39 (JMA), Jamaica Manufacturing Assocation. (2013, January 16). Manufacturers Make their Mark. Retrieved from The Gleaner: jamaica-gleaner.com/gleaner/20130116/news5.html "In its early stages of development, manufacturing was ripe with opportunities, having the support of Government, a budding entrepreneurial class, a local market of over one million people, and an abundance of labour. The sector quickly diversified from sugar and rum into producing a wide range of manufactured products such as garments, processed foods, machinery, and electrical equipment, which resulted in Jamaica experiencing impressive real growth. Manufacturing became the largest contributor to GDP in 1978, employing about 79,000 persons - approximately 10 per cent of the total employed labour force - and was about 10 per cent of total merchandise exports...The 1970s, however, had mixed fortunes. Between 1974 and 1978, the manufacturing sector faced tremendous challenges as a result of restrictive government and trade policies as well as limited imports. These policies, while creating a protective environment, also affected the availability of important raw materials, spare parts, and the resources that manufacturers needed for production. There was also a fixed exchange-rate policy and high inflation as the oil crises of 1973 and 1978 affected the country and eroded the financial incentives to exporters." 
primarily along the industrial belt of Marcus Garvey Drive and Spanish Town Road, which offered direct access to the commercial hub for export. The manufacturing businesses required a mobile workforce and were reluctant to hire individuals who resided in West Kingston for fear of having their companies become targets for criminals.

The KMA is divided therefore into two areas-uptown and downtown-separated by a traffic junction known as Cross Roads. Uptown sections of KMA are located north of Cross Roads, while downtown is located south of Cross Roads. What little attention was given to Downtown Kingston focused primarily on the expansion of its port facilities and the beautification of the waterfront for commerce associated with tourism. The specific restructuring and overseeing of development in urban slums fell under the auspices of the government, political parties, and the practice of clientelism.

Politics of the KMA: In addition to its commercial and industrial significance, downtown Kingston is also the center of urban politics. All government ministries and central administrative offices are located downtown, and the city is center stage for all major political rallies held during elections. Primarily because in the case of Jamaica, the patronage system has ensured that low-income groups and communities are integrated into the political system- providing political parties with a hardcore voting base- more so than the middle class or any other group(s) in Jamaican society. Within the KMA, there are fifteen political constituencies ${ }^{40}$ [see Figure 19]. Of these fifteen constituencies, nine

\footnotetext{
${ }^{40}$ KMA political constituencies: St Andrew West Rural, St Andrew Western, St Andrew West Central, St Andrew South Western, St Andrew Southern, St Andrew East Central, St Andrew South Eastern, St Andrew Eastern, St Andrew East Rural, St Andrew North Eastern, St Andrew North Western, St Andrew North Central, Kingston Western, Kingston Central and Kingston Eastern and Port Royal
} 
have been identified as garrison communities ${ }^{41}$ [see Figure 20]. The garrison constituencies located in the KMA account for $60 \%$ of all identified constituencies within the KMA.

${ }^{41}$ See footnote 5 


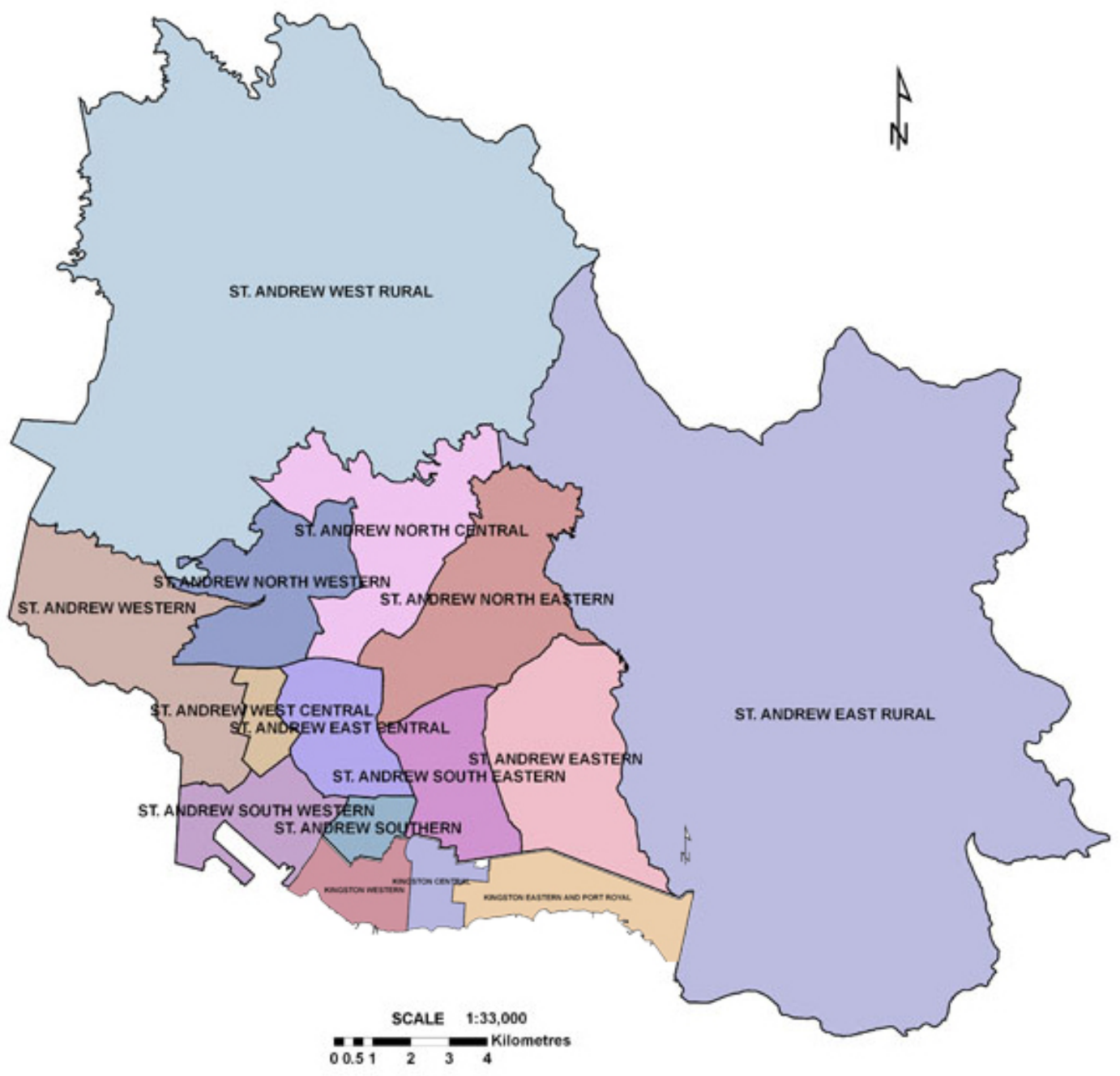

Figure 7 Political Constituencies in KMA 


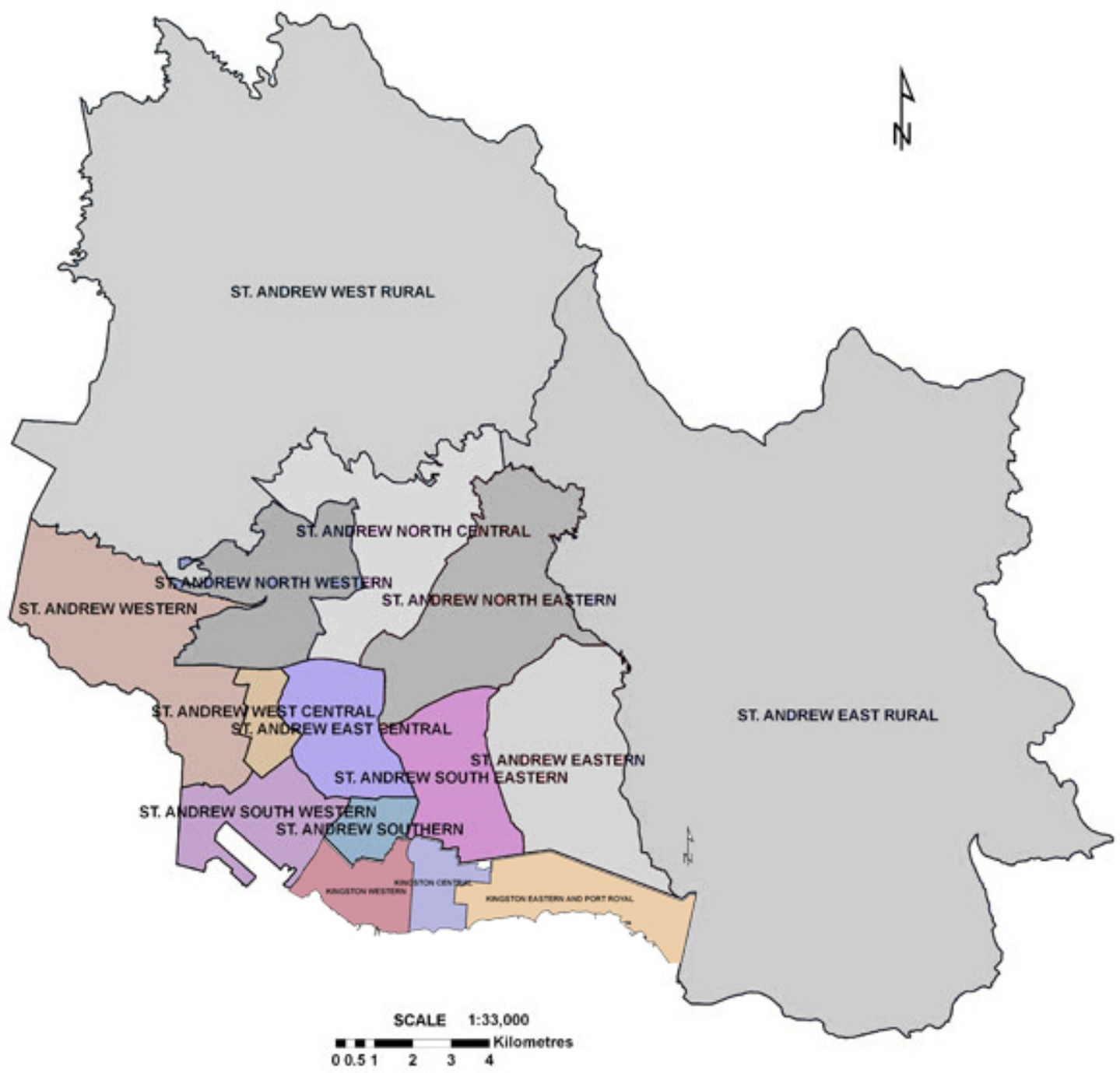

Figure 8 Garrison Constituencies in KMA 


\section{Typology of the Garrison}

Garrison constituencies can be divided further into multiple electoral divisions and then into several communities. It is even possible to divide specific communities into garrison zones/neighborhoods. For reasons of analysis, the literature continues to primarily define a garrison as a constituency and/or a community that is framed by a territorially distinct political division that aligns with either of the two main political parties. However, this static perception of the garrison clouds the complex and the dynamic nature of the various classifications of the garrison 'type' that is generally examined. Not only do we find garrisons existing at multiple levels [political constituencies, electoral divisions, communities, neighborhoods], but as discussed in chapter four, we must also be prepared to classify the wide variety of gang types that reside within the garrison and that help to frame its identity. For University of the West Indies Lecturer Christopher Charles (interview July 18, 2012) the term garrison is multifaceted:

We must first make a distinction between garrisons, a garrison community, and a garrison constituency. A garrison constituency is an electoral district as you call them in the American system. [In the case of Jamaica] it is actually a electoral district where one of the two parties have exclusive governance in terms of control, and that control is maintained by criminals who support the political party, who support the Minister of Parliament, who ensure that the competing political activists or party members cannot campaign in that community. Therefore, it is a voting block created by the political parties to maintain their 
power bases by using informal party machinery. This machinery actually defends the space on behalf of the party.

A closer look at the garrison constituencies of St Andrew Southern and Kingston West, provide a preview of the complexity of the garrison phenomenon in Jamaica's urban areas. These two constituencies are home to some of the first garrison communities ever created in Jamaica, and are located in the center of the garrison sprawl that has taken place since the 1960s. Within these two garrison constituencies, we are able to identify the electoral divisions of Trench Town and Admiral Town, both within the garrison constituency of St Andrew Southern, as well as within the electoral divisions of Denham Town and Tivoli Gardens, and both within the garrison constituency of Kingston West. These electoral divisions are divided into several infamous garrison communities such as Tivoli Gardens, Rema, and Arnett Gardens to highlight a few [see Figure 9]. 

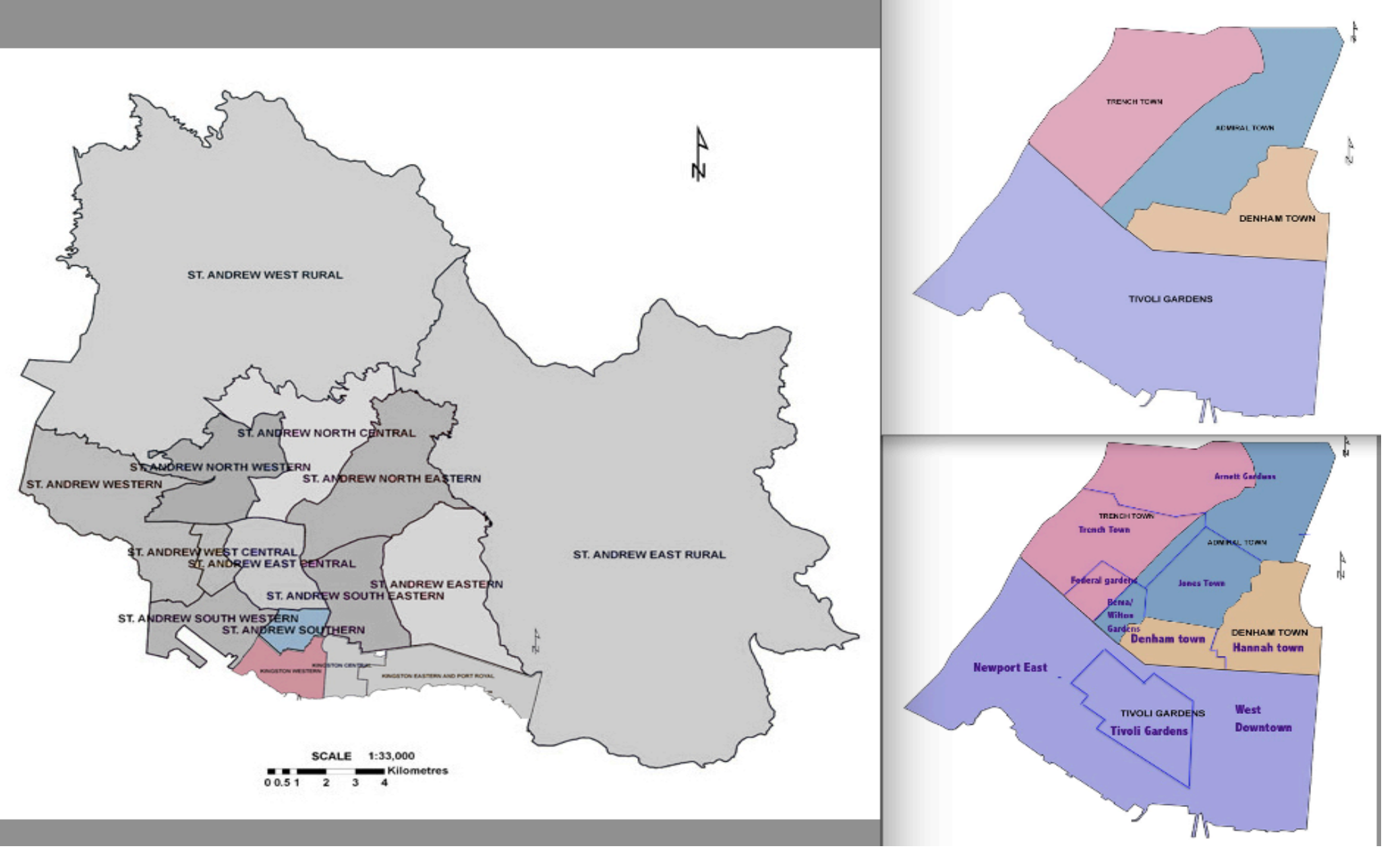

Figure 9 Garrison Constituencies, Electoral Divisions, \& Communities 
Understanding how garrisons are created helps in understanding how they function, as well as how they evolve. First, there is a clear acceptance that the state is responsible for the formation of the garrison through the development of large-scale government housing schemes. This perspective of a garrison helps to generate a notion of the garrison as large cohesive areas. Second, there is also a firm expectation that almost all garrison residents maintain a homogenous political identity and that they consistently vote accordingly. In the 1997 published Kerr report, common features of the garrison were identified by:

- Controlled entry and exit of individuals

- Strong relationship between gang leaders and Constituency leaders

- Ensured access to work contracts and jobs

- Highly organized political gangs

- Clearly defined boundaries and territories

- Insulation from security forces and the police because of political protection, and

- Consistent and longstanding pattern of homogenous voting for candidates of a particular political party

However, as Figurea points out, " there are few constituencies where the vast majority of the territory has been garrisoned. To focus on constituencies alone [or any one type for that matter] is to miss the significance of the garrison phenomenon as a whole" (Kerr, 1997). The current study identifies three generalizable categories of garrisons based on their history and context and not necessarily following a set timeframe. While some garrisons share similar features, they may not necessarily have formed within the same timeframe. Incentives for political alignment and the history of 
community interactions have proven to be strong indicators for how and why certain areas share similarities.

Original garrisons. The first category consists of the original garrisons created in the 1960s through the1970s. These garrisons are aligned more closely to the common features identified above. The original garrisons of Rema [1963], Tivoli Gardens [started in 1963 and completed in 1968], and Arnett Gardens, after [1972] (Gray 2004) all consist of government housing schemes, and very clear territorial boundaries and markers. With permanent structures, plumbing, electricity and other basic amenities they benefit from a higher level of urbanization than their surrounding areas. Further, although categorized as urban slums, the distribution of poverty among these communities in relation to other communities within the KMA also indicates that although these areas are poor, they are not the poorest.

In terms of basic unmet needs all three communities range between a three and four, on a scale where a ranking of one means that no basic needs are being met, and a five means that most if not all basic needs are being met (Economic Commission for Latin America and the Caribbean, 2010). According to the Planning Institute of Jamaica, both the Population Census 2001 and The Survey of Living Conditions 2002 indicate that the garrisons of Tivoli Garden, and Arnett Gardens both have relatively low levels of consumption-based poverty. Tivoli Gardens, surprisingly, indicated that only approximately $0.0-13.65 \%$ of its residents fell below the poverty line while Arnett Gardens reveals that approximately $13.66-20.86 \%$ of its residents fell below the poverty line. However, even within this first typology we can identify a few key differences. Despite having the advantage of being one of the original garrisons with government 
housing, Rema's location and history has forced a large number of its residents to falling below the poverty line. The reason for the high level of poverty is because Rema is a JLP enclave almost completely surrounded by PNP garrisons and has experiences a high degree of violence defending its boundaries.

Second-generation garrisons. The second category of garrisons or second generation garrisons, are comprised of a combination of established communities aligning along political lines and of newly established political zones of control forming within these older communities; both in search of material rewards from political parties and the government in power. With the JLP's successful establishment of Tivoli Gardens several communities, for example, Denham Town, Hannah Town, and Southside began to align alongside the JLP. A 1969 election that ended in favor of the PNP saw a subsequent growth in the number of politically aligned areas for the PNP as well. Several communities within the Kingston Central and St Andrew Southern constituencies like, Trench Town, Jones Town, and Rae Town became staunch PNP supporters with the aim of securing a stake in resources that previously were denied them under the JLP.

During the early 70 's and 80 's, there was an explosion in the number of areas that began to identify themselves as garrisons. Under both political parties while in power, there was a liberal and preferential distribution of resources into communities through community development projects and through social development organizations such as youth groups, and sports clubs. These resources were offered in exchange for political loyalty to the "government of the day." Within this category we find a wide cross section of established communities and specific areas within them that strategically transitioned 
into garrisons at various times and under different governments. These transitions were because of several factors such as:

- Whether the community/area was a squatter community looking for formal recognition and resources from the state

- Whether the community/area was a result of ostracized individuals from several or one specific community who refused to align politically with one specific party

- The timing of whether critical power vacuums developed and was able to fracture the politically aligned gangs that controlled specific communities and areas. The influx in the number of garrisons also led to an influx in the level of crime and violence as these areas vied to maximize and secure clientelistic relationships with the state. Access to guns and other weapons not only contributed to high levels of crime, but they also helped to perpetuate a high level of violence as groups in possession of guns were able to define their status within their community and others. Access to guns determined who the political power players were, contributed to the type of political attacks carried out on opposing political gangs, and allowed communities to protect themselves from attacks, during and after election periods.

In addition, the later part of the 1970's and early 80's brought with it the privatization of the housing industry and structural reform programs. As such, there was a reduction in community development programs, and a shift from provider-based housing to support-based housing. These second generation garrisons did not benefit from rentfree government housing as the first set of garrisons did. For already established communities such as Trench Town, housing was a combination of squatter settlements and dilapidated old government housing from colonial times. 
As multiple garrisons began to pop up within specific political constituencies such as PNP backed Kingston Central and St Andrew Southern, access in and out of politically aligned garrisons became more lax. With several areas within a community fracturing into garrison bases, there was also a marked difference in how community power was dispersed. Power among this category of garrisons appeared be more hierarchical, with several community leaders having an unequal share in decision-making. Representing their respective areas, garrison leaders were able to secure varying degrees of labor and resources and collectively influenced the political influence of the community as a whole.

Garrison Enclaves. The third category of garrisons to evolve with the city's urban center can be referred to as garrison enclaves. These enclaves generally are characterized by small physical spaces spanning no more than a couple streets or blocks. They are comprised of a high concentration of gang members loyal to a specific leader, whose central aim is to accumulate power and status and to provide for the individuals who follow them, as opposed to the larger community. As a result, enclaves may support the opposing political party from with another political party's zone, or it might be strategically located along the border of an opposing party. Mathews Lane is an example of one historic PNP enclave ${ }^{42}$ that is located along the border of the JLP backed Kingston West Constituency.

While access in and out of these areas or tightly controlled, territorial markers are typically less distinct, and may consist of large debris blocking access to streets and/or spray painted gang names or affiliations on walls and buildings. As these small enclaves

\footnotetext{
42 Mathews Lane has a historic party affiliation that goes as far back as the 1940s when the PNP mobilized political activities into "Group 69".
} 
are within larger communities and neighborhoods they tend to be in close proximity to other enclaves or just fractioned off from a larger garrison. Safe zones between these enclaves include; empty fields, gullies, a main road or a few adjoining streets designated as "no man's land". As a result, there is generally more turf wars and violence between the garrisons within this category.

Among garrison enclaves' political loyalty is balanced with an active involvement in criminal gang activities outside of election periods in order to build their reputation and to generate resources that span outside of political spoils. Rather than falling under a hierarchical community power structure where these enclaves report to area dons, enclaves are run by gang leaders who precariously balance the control of their enclave by exerting high levels of violence and control. In communities like Mountain View, the PNP affiliated enclaves of Jarrett Lane and Saunders Avenue that are surrounded by JLP enclaves of Jacques Road and 83 Lane tend to generate high levels of violence and turf wars outside of election periods.

The problem with garrison typologies. However, even with a benchmark of political alignment and community history from which to examine garrisons, it is clear that even these minimal characteristics come with their own share of differences across the various makeups of what defines a garrison. A typology of the garrison reveals that in reality theses locations tend to vary not only in history and origin, but also in size, the level of urbanization, levels and types of violence, gang makeup, the clarity of their boundaries, types of criminal activity and by their level of transnational activities. For example, Tivoli Garden's proximity to the sea has made it possible for it to escape the pressure of being attacked on all sides. Its prominence as the core of the JLP voting 
base has also made it privy to extended JLP garrison areas and zones that act as a buffer from opposing garrisons; areas such as Denham Town and Rema [before the 1990's]. Tivoli has taken on the characteristics of an enclave. The garrison has also historically been controlled by one dominant gang despite its larger size in relation to other garrisons, Within Tivoli Gardens, neighborhood zones all fall under the central power of the Tivoli Don. Similarly, in other garrisons like Rema, the community suffers from a lower level of urbanization and higher levels of consumption defined poverty than its counterparts because of its violent wars with surrounding PNP zones before the 1990's and later with Tivoli when it switched political allegiance. In Arnett Gardens, the large numbers of secondary garrisons that arose has resulted in a disregard for central leadership and has contributed to the further fractioning of the garrison into various types.

Most garrisons are a complex mix of deteriorating residential and business areas. Within them, the various types of housing, socio-economic status, proximity to factories and markets, political history, and proximity to border garrisons all spatially divide these neighborhoods. In the garrison communities of Arnett Gardens and Trench Town, we find several garrison areas with notorious names such as Mexico, Angola, Texas and Zimbabwe. Some garrison areas, are seen as minor political pawns, while others are seen as central zones for support. Some have more firmly established transnational ties resulting from community migration patterns, while others must rely on more localized support. Access to jobs and contracts, access to entry and exit of communities, and the level of organization of urban gangs within are all no longer solely dependent on political resources. Ultimately, multiple variables influence the common features of garrisonsthereby making it hard to truly pin down a distinct typology. 


\begin{tabular}{|c|c|c|c|c|c|c|}
\hline \multirow{2}{*}{$\begin{array}{c}\text { Community } \\
\text { Sub- } \\
\text { Case/District }\end{array}$} & \multicolumn{2}{|c|}{ Trench Town } & \multicolumn{2}{|c|}{ Jones Town } & \multicolumn{2}{|c|}{ West Kingston } \\
\hline & $\begin{array}{c}\text { Amett } \\
\text { Gardens }\end{array}$ & Rema & Jones Town & Craig Town & Tivoli Gardens & $\begin{array}{l}\text { Matthews } \\
\text { Lane }\end{array}$ \\
\hline $\begin{array}{c}\text { Socio-economic } \\
\text { Status }\end{array}$ & Less Poor & $\begin{array}{l}\text { Extremely } \\
\text { Poor }\end{array}$ & Very Poor & Poor & Less Poor & Poor \\
\hline $\begin{array}{l}\text { Intra-City } \\
\text { Location }\end{array}$ & Inner-city & Inner-city & Inner-city & Inner-city & Inner-city & Inner-city \\
\hline $\begin{array}{l}\text { Socio-economic } \\
\text { characteristics }\end{array}$ & $\begin{array}{l}\text { Deteriorating } \\
\text { residential and } \\
\text { business areas } \\
\text { (fairly recent, } \\
1980 \text { s) }\end{array}$ & $\begin{array}{l}\text { Deteriorating } \\
\text { residential } \\
\text { (fairly recent, } \\
1980 \text { s) }\end{array}$ & $\begin{array}{l}\text { Deteriorating } \\
\text { residential and } \\
\text { business areas } \\
(1970 \text { s) }\end{array}$ & $\begin{array}{l}\text { Deteriorating } \\
\text { residential; } \\
\text { cycles of } \\
\text { destruction }\end{array}$ & $\begin{array}{l}\text { Deteriorating } \\
\text { mixed } \\
\text { residential, } \\
\text { near markets } \\
\text { and factories }\end{array}$ & $\begin{array}{l}\text { Deteriorating } \\
\text { residential, } \\
\text { including CBD } \\
\text { with all major } \\
\text { markets }\end{array}$ \\
\hline $\begin{array}{l}\text { Internal Spatial } \\
\text { Division }\end{array}$ & $\begin{array}{l}\text { Bifurcated into } \\
\text { upper and } \\
\text { lower sections } \\
\text { (then into } \\
\text { different } \\
\text { housing } \\
\text { schemes) }\end{array}$ & $\begin{array}{l}\text { Bifurcated by } \\
\text { gully (Collie } \\
\text { Smith Drive) }\end{array}$ & $\begin{array}{l}\text { Bifurcated into } \\
\text { upper and } \\
\text { lower sections }\end{array}$ & $\begin{array}{l}\text { Differentiated } \\
\text { by socio- } \\
\text { economic } \\
\text { status }\end{array}$ & $\begin{array}{l}\text { Closed } \\
\text { community } \\
\text { with } \\
\text { community } \\
\text { center in the } \\
\text { middle }\end{array}$ & $\begin{array}{l}\text { Bifurcated into } \\
\text { upper and } \\
\text { lower sections } \\
\text { surrounding } \\
\text { transportation } \\
\text { and market } \\
\text { hub }\end{array}$ \\
\hline $\begin{array}{l}\text { Political Party } \\
\text { Characteristics }\end{array}$ & $\begin{array}{l}\text { Garrison } \\
\text { (PNP }^{1} \\
\text { stronghold) }\end{array}$ & $\begin{array}{l}\text { Garrison } \\
\text { (traditionally } \\
\text { JLP² } \\
\text { stronghold, } \\
\text { recent }\end{array}$ & $\begin{array}{l}\text { Politically } \\
\text { aligned } \\
\text { community } \\
\text { (PNP) }\end{array}$ & $\begin{array}{l}\text { Contrasting } \\
\text { political party } \\
\text { alignment } \\
\text { (often caught } \\
\text { in warfare }\end{array}$ & $\begin{array}{l}\text { Garrison (JLP } \\
\text { stronghold) }\end{array}$ & $\begin{array}{l}\text { PNP } \\
\text { stronghold }\end{array}$ \\
\hline
\end{tabular}

Figure 10. Characteristics of Select Garrison Communities in the KMA

Note. Table taken from Duncan-Waite, I., \& Woolcock, M. (2008). Arrested development: The political origins and socioeconomic foundations of common violence in Jamaica. University of Manchester Press. 


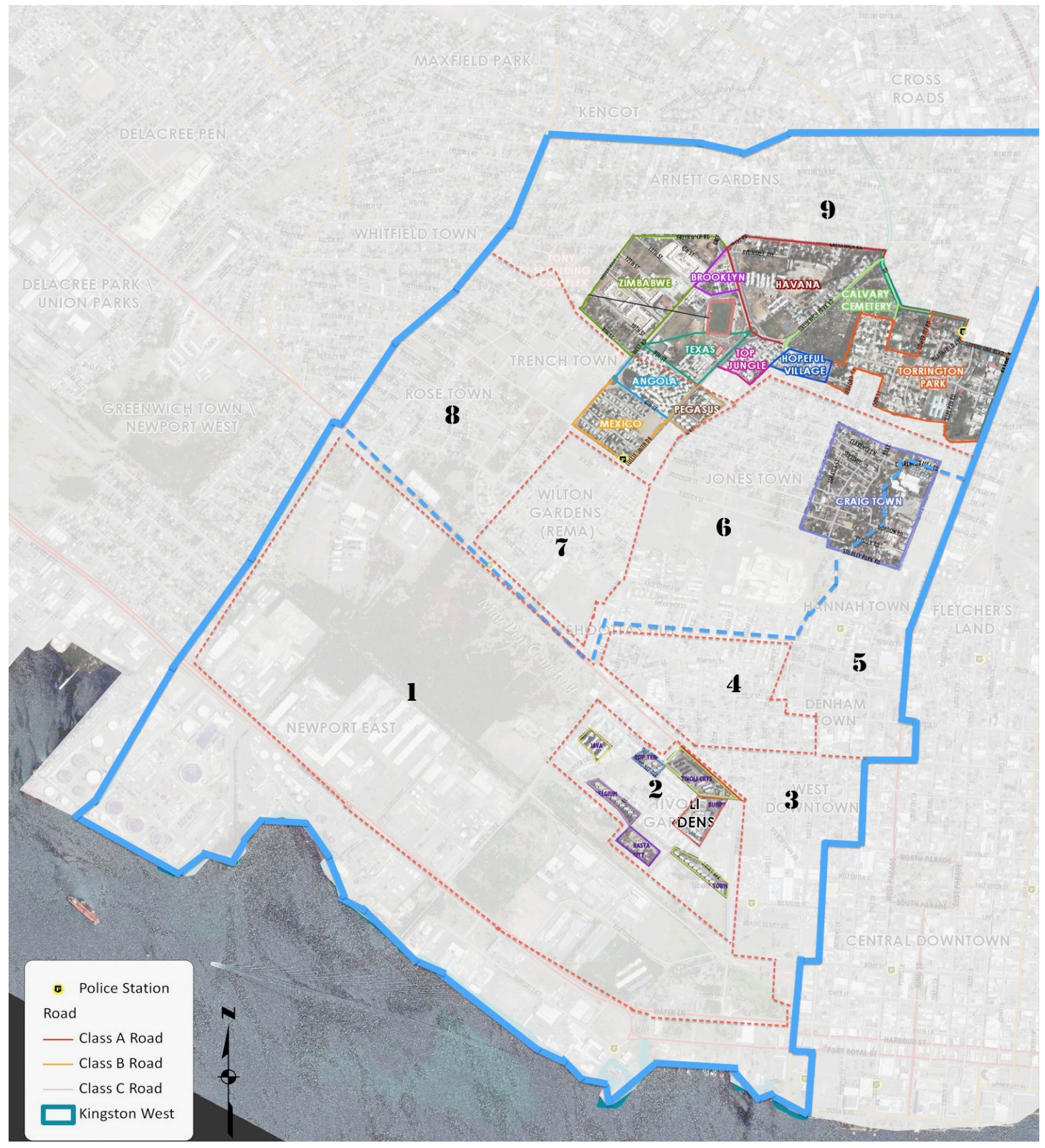

Figure 11 Map of Garrison Types

Note: This map shows the breakdown of identifiable garrison areas within the Kingston West and St Andrew Southern constituencies. Not only are we able to identify the two garrison constituencies but we are able to view the proximity of a complex typologies of garrison areas that include original garrisons, second generation garrisons and garrison 
enclaves. Zone 1: Newport East; zone 2: Tivoli Gardens; zone 3: Downtown West; zone 4: Denham Town; zone 5: Hannah Town; zone 6; Jones Town; zone 7: Federal Gardens \& Wilton Gardens/Rema; zone 8; Trench Town; zone 9: Arnett Gardens.

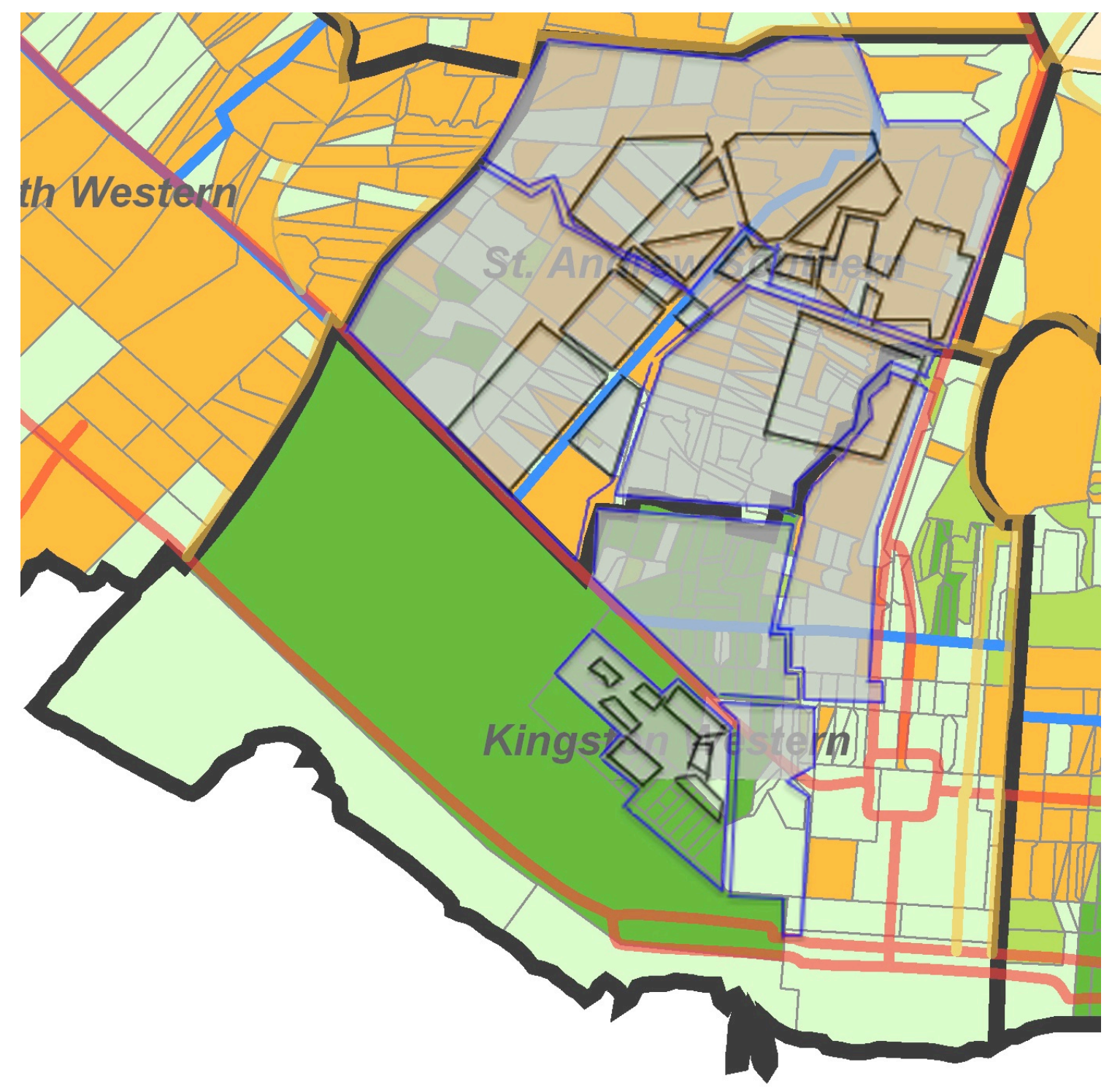

Figure 12 Map of Garrisons along Voting Divisions

Note. This map shows an outline of various garrison types overlying the voting division in the 2007 general election. Dark green shaded areas represent voting blocks where 90100 percent of the votes supported the Jamaica Labour Party [JLP]. Dark Orange shaded 
areas represent voting blocks where 90-100 percent of the votes supported the People's National Party [PNP]. Although we can identify the Kingston West constituency as primarily aligned with the JLP and the St. Andrew Southern as primarily aligned with the PNP, this Map reveals areas within strongly align voting enclaves within areas that equally are aligned to the opposing party

\section{The Role of Urban Gangs within the Garrison}

The establishment of the garrison and its various typologies also is tied to the gangs residing within these territorial boundaries that wield power. These gangs generally constrained by low socioeconomic means are able to taking advantage of the community based patronage system in order to obtain power and gain greater access to entrepreneurial activities. The idea of the Jamaican gangs have been absorbed into the garrison identity and has created a complex melding of several of the characteristics and features that clearly distinguish between the two.

These identities and activities are framed not only by the variations in the garrisons discussed above, but also by the various role(s) that the gang assumes. Residing within garrison areas gangs take on a variety of roles:

Political activists. Mobilizing community votes, organizing political rallies and staging demonstrations; often times, gang members will use their ability to politically mobilize the community and other allegiant communities to show support for gang leaders when the law detains them. One such example was seen in 1998 when Donald 'Zekes' Phipps, the area leader for PNP zoned Mathews Lane was arrested on charges of murder and illegal possession of a firearm. Demonstrators gathered outside the police station demanding his release. In order to appease the crowd, Zekes was taken to a 
balcony on the building where he ordered his followers to return to their homes. All charges against him at that time were later dropped (Hall, 2010). Similarly, with the more recent extradition of Christopher 'Dudus' Coke in 2010, mostly female demonstrators dressed in white took to the streets with placards that read, "Leave Dudus alone", "Jesus die for us, we will die for Dudus", and "God First, Dudus Second".

Middlemen in the distribution of benefits. Maintaining the dynamic between community support and political spoils, gang leaders negotiate the receiving of benefits in exchange for political loyalties during election time. As middlemen, the gang leaders further determine how these spoils will be distributed within the community; who gets what, when, how, and why.

Enforcers of community loyalty. As middlemen in the distribution of benefits, gangs and their leaders are given an elevated status within these communities. Their access to guns and other weapons further allowed them to establish and reinforce community rules and laws, and helps them to control the level of crime and violence that takes place within the community. Not only do gang leaders reinforce political allegiance, but they also enforce stricter community loyalty to the gang. Establishing an informal justice system or 'kangaroo court' (Johnson \& Soeters 2008, p. 117), gang leaders eke out a wide range of punishment to wayward gang members, as well as to community members and community outsiders who disrupt the dynamic of the community. 


\begin{tabular}{|c|c|c|c|c|}
\hline \multicolumn{5}{|c|}{ Selected "Cases" in the Informal Justice System } \\
\hline $\begin{array}{c}\text { Electoral } \\
\text { Constituency }\end{array}$ & Crime & Perpetrator & Victim & Punishment \\
\hline Western Kingston & $\begin{array}{c}\text { Kicked a } \\
\text { pregnant woman }\end{array}$ & $\begin{array}{l}\text { Young adult } \\
\text { male }\end{array}$ & $\begin{array}{l}\text { Young adult } \\
\text { female }\end{array}$ & Male shot in the leg \\
\hline Western Kingston & Fighting & $\begin{array}{l}\text { Two young } \\
\text { women }\end{array}$ & None & $\begin{array}{l}\text { Warning to the } \\
\text { women }\end{array}$ \\
\hline Western Kingston & $\begin{array}{l}\text { Refusalinability } \\
\text { to repay loan }\end{array}$ & Resident & Don/resident & Execution/mediation \\
\hline Westem Kingston & $\begin{array}{l}\text { Repeat domestic } \\
\text { violence }\end{array}$ & Male partner & Female partner & Beating \\
\hline Western Kingston & $\begin{array}{l}\text { Tried to } \\
\text { confiscate } \\
\text { property }\end{array}$ & Shooter & Resident & Execution \\
\hline $\begin{array}{l}\text { Southwest } \\
\text { St. Andrew }\end{array}$ & $\begin{array}{l}\text { Support for the } \\
\text { rival party }\end{array}$ & Any resident & None & $\begin{array}{l}\text { Family expelled } \\
\text { from community }\end{array}$ \\
\hline $\begin{array}{l}\text { Southwest } \\
\text { St. Andrew }\end{array}$ & Physical assault & $\begin{array}{l}\text { Male young } \\
\text { adult }\end{array}$ & Male youth & Slaps to the face \\
\hline Eastem St. Andrew & $\begin{array}{l}\text { Extortion, arson, } \\
\text { and murder }\end{array}$ & Shooter & $\begin{array}{c}\text { Male } \\
\text { shopkeeper }\end{array}$ & Execution \\
\hline Central Kingston & $\begin{array}{c}\text { Motorist ran over } \\
\text { bicycle }\end{array}$ & $\begin{array}{l}\text { American } \\
\text { researcher }\end{array}$ & Teenage boy & $\begin{array}{c}\text { Monetary } \\
\text { compensation }\end{array}$ \\
\hline $\begin{array}{c}\text { West Central St. } \\
\text { Andrew }\end{array}$ & $\begin{array}{l}\text { Speaking to cops } \\
\text { after gun found }\end{array}$ & $\begin{array}{c}\text { Pregnant } \\
\text { woman and } \\
\text { her mother }\end{array}$ & None & $\begin{array}{l}\text { Execution of both } \\
\text { women }\end{array}$ \\
\hline & & & & \\
\hline
\end{tabular}

Figure 6.The Informal Justice System

Note. Table taken from Charles, C. A., \& Beckford, O. (2012). The Informal Justice

System in Garrison Constituencies. Social and Economic Studies , 61 (2), 51-72.

"Shows several 'cases' that were 'disposed' of in the informal justice system in several garrison constituencies" within the KMA 
In the cooperating witness statement against Christopher 'Dudus' Coke, multiple examples of how Coke would exact judgment on wrong doers both within his criminal organization and within Tivoli and the surrounding JLP affiliated communities were revealed. Rather than report crimes directly to the police, community members would report these crimes directly to Dudus whenever he was at his office located within Tivoli Gardens. As the area don, Dudus would apply an established set of punishments depending on the offense. For example, domestic abuse would result in a public beating of the abuser, stealing resulted in imprisonment and then a gunshot to the hand or foot. Other offenses such as a repeat offense or informing on the organization or raping a person would result in death (Jamaica Observer, 2012a).

Community Defenders. By turning a blind eye to gang activity and publically claiming allegiance to a political party, community members not only receive welfare from the state through the gang, but they also receive protection from attacks carried out by other gangs and garrisons. Regardless of whether these attacks are a result of political affiliation, turf wars, or tied to illegal activities the gang mobilizes, recruits and expands its ranks from within the community. Depending on how organized the gang is, community members play a role in defending their community whether as vigilant residents who lookout for suspicious individuals, armed patrol, or as more permanent members of the gang. In the case of JLP backed West Kingston, after the extradition of Christopher 'Dudus' Coke, residents in the areas of Tivoli Gardens, Denham Town, Luke Lane publically complain that as a result of the power vacuum they are being terrorized by gangs from the PNP backed Mathews Lane. Further, there are additional reports of violence associated with area gangs within the Kingston West area mobilizing and vying 
against each other for power (Spaulding, 2013). Further, whenever the political party backing a specific garrison is not in power, gang leaders also utilize their role as enforcers to ensure that the benefits they received in the past are protected when the opposing political party is in control. Gang members deter police and public works workers from entering the area in order to protect resources such as rent-free living and free access to utilities.

Criminals. Gangs residing within the garrisons have also taken advantage of their access to weapons as political enforcers, to carry out criminal activities. Gangs receive the most resources when the political parties they support are in office, and when it is an election year. During the times when their parties are not in power, gangs use their access to weapons to maintain the flow of resources into the community and to protect access to resource they receive from their constituency leaders. Criminal activities such as extortion, drug running, kidnappings and murderers for hire, all help to bring resources in when the party is not in power. In addition, increases in illegal activities in these areas under one political party's administration help to fuel outcries of inefficient management by the opposition.

\section{A Typology of Jamaican Gangs}

In the same way that there are several variations of what constitutes a garrison, the multiple roles of urban gangs have resulted in a multiplicity of gang types--that vary by age, level of organization, size, location, motivation, and level of criminal activity. As a prominent community leader (interview July30,2012) points out, gang structures in Jamaica are very diverse. Looking at gangs within areas located in the Kingston Metropolitan Area and outside of this area, he stated that there are only two structured 
gangs in Jamaica right now ${ }^{43}$ the One Order Gang and the Clansman Gang-- both of which operate in Spanish Town. Even though there has been some breakaway into smaller groups, for example some individuals calling themselves the No Order Gang, these groupings were not as formally structured. Even in the case of Kingston's Tivoli Gardens, while recognized as one large gang controlled garrison [prior to May 2010] in reality Tivoli housed two distinct gangs - the Shower Posse and the Presidential Clickunder one central leadership. Further, the interviewee also referred to the Rat Bat Gang, as an example of other types of gangs within Jamaica's urban areas that are organized around overseas assistance and affiliation. As such, this gang rather than being isolated to one specific urban space would have several criminal groupings within several communities that identify themselves as members of the Rat Bat Gang. With the help of research carried out by Leslie (2010), this research identifies four different typologies of the Jamaican gang.

The first typology, according to Moncrieffe (1998) argues that the best way to understand these variations is see them as falling on a spectrum. One that ranges from loosely organized gangs on one end, moderately organized gangs in the middle, and highly organized larger gangs on the other end. At each point on the spectrum leadership type, degree of hierarchy, formalization of role and rituals, and the specificity of activities that they carry out, determines the organization of the gang. Further, the level of organization determines the degree of threat the gang poses to the community in which it resides, the life cycle of the gang, and its ability to expand in scope beyond the confines of the community and even internationally.

43 Given the recent dismantling of Kingston based Tivoli Gardens in May 2010 
The second typology of gangs is derived from the works carried out by Rodgers (1999) and Laurent (2007). Concerned with the growth of violent and criminal youth formations, these scholars distinguish between the urban phenomenon of small loosely organized youth gangs and more firmly structured, internationally affiliated crime groups comprised of mainly adults. Here adult crime groups are seen as taking part in more clandestine and formally structured crime, and are intent on corrupting local institutions in order to maximize their entrepreneurial gains. On the contrary, youth gangs are the more widely occurring localized and violent criminal groups found within garrison areas.

These groups tend to have a younger membership between the ages of 14 and 24 years and are concerned more with protecting turf and gaining respect than establishing a financial empire through organized activities such as drug trafficking. Although gang members tend to be educated, or has some level of high school education, "roughly 50,000 of them are unemployed, and just under 80,000 are outside of the labor force, according to the Statistical Institute of Jamaica" (Brooks (2010).

Recent studies in Jamaica reveal, however, that the youth gang phenomenon can no longer be characterized only by violent and criminal activities taking place in the community. According to Meeks (2009), 70\% of students have reported gang presence and influence in schools. Moreover, youth gang activities have expanded from turf wars to extortion, drug use, theft, sexual harassment, and drug sales. Ultimately, the youths that make up these local gangs are potential recruits for the larger, more organized crime groups that Rodgers (1999) and Laurent (2007) do not focus on.

The third typology of Jamaica gangs purported by Mogensen (2003) focuses on distinguishing between two gang types- area gangs and corner gangs- differentiated by 
their degree of political allegiance. For Mogensen (2003), area gangs are communitylocated gangs that control entire communities and neighborhoods that are tied historically to political violence and political patronage of the 1960s-1980s. Conversely, corner gangs are less organized and informal gangs that rapidly evolved post-1980's. These gangs are comprised of youths who are primarily involved in street crime and other low level criminal activity, and who are less obligated to a specific political party.

By looking at the factors that gangs use to ensure status and power, Mogensen (2003) explains the rapid growth of corner gangs because of increased access to guns and increased access to resources from criminal activities. Area gangs are no longer the only sources of guns. Where access to guns where controlled by political parties in the 1960s1980s and distributed to area gangs for political protection, there is now a booming black market for guns in Jamaica that bypasses political ties. As discussed in chapter 6, gangs are actively involved in weapons trading, and high caliber guns and ammunition can be purchased within the garrisons at competitive pricing. These factors have also resulted in area gangs increasingly becoming involved with organized criminal activities.

The shift to more criminal-based activities however does not extinguish political allegiance. Area gangs still are tied to specific political parties and corner gangs exist in communities dominated by area gangs loyal to a specific political party. It is not uncommon for corner gangs to identify with the dominant party in the community is which they reside, or to form alliances with area gangs during election times. Mogensen (2003) points out that this distinction helps us to differentiate "between 'politics-war' [election time violence] and 'turf-war' [inner community disputes]. While 'politics-war' 
always involved rival communities each supporting different parties, 'turf-war' could involve two communities that support the same party" (p. 4).

The fourth and final typology looks at the complex formation and evolution of gangs over time. Similar to Moncrieffe (1998), Mainwaring (2007) asserts that it is pointless to study gang typology by focusing on whether gang typologies fit exactly within one category or another. That is because regardless of whether gangs are smallscale locally based criminal groups or if they are larger, more formalized and transnational groupings, in all their types, gangs are non-state actors intent on maximizing their commercial goals and needs. Like other non-state actors, their "punitive objective is to neutralize, control, or depose governments to ensure self determined ends" (Mainwaring, 2007, p. 2). Unlike insurgents staging a coup or carrying out a prolonged revolutionary war, gangs neutralize and control national territory, and the people that reside within it, one street or neighborhood at a time (Manwaring, 2007, p. vii).

According to Mainwaring (2007), the degree to which gangs are able to control, neutralize, and even depose a government depends on whether they are a first-generation, second-generation, or third-generation gang. Given time, gangs naturally and slowly evolve. However, the path they take is non-specific and dependent primarily on leadership style and the desire and ability to pursue economic openings that will maximize their profits and potentially expand their organization. From the perspective of an organization that slowly evolves, first-generation gangs include all criminal groups with a loose and unsophisticated leadership structure focused on criminal activity that is largely opportunistic and small-scale. First-generation gangs typically take part in petty crimes such as robberies, hold up's, break-ins and small-scale drug sale and use. They are 
generally only able to limit the function of the state by providing their localities with turf protection and safety from gang activity in exchange for money.

Unlike first-generation gangs, second-generation gangs are more centrally controlled and they structurally are organized in a way that best fits the framework of a business intent on maximizing commercial gains. Mainwaring (2007) characterizes this gang type as one focused on protecting a market that it has already established a presence in. An involvement in illegal markets such as the drug trade tend to be ideal for second generation gangs as it requires a group with an intimate knowledge of local markets and culture, limited in their ability tap into global markets on their own, yet capable of mobilizing local market shares and forging transnational connections.

In order to do so, second-generation gangs employ a higher level of violence in keeping with their economic interests and are characteristic of global players who are lower level players, middlemen, or outsourced by larger players for a specific skill set. These activities may include smuggling of goods; trafficking drugs, weapons, or human trafficking; or providing mercenary services and specialized levels of violence and ruthlessness. Globally, violence and services rendered are seen as merely another line of profit. Locally, violence is seen as a means of protecting markets and controlling competition within large spatial areas, or across multiple spatial areas. It is also a means of controlling or neutralizing state access and actions.

Similar to a successful business, a successful gang is one that has been able to establish a positive reputation in the markets they enter into. The reputation of a gang leads to an expanding job market, new interactions and alliances, and the expansion of the business itself. With time, Mainwaring (2007) argues that successful second- 
generations gangs are able to transition into third-generation gangs. Local criminal markets have expanded spatially and there is a supplemental increased in the number of areas they supply or conduct business in or with. There is also an increase in the types of violent activities they carry out, as they become more established in the global market, so too do their criminal activities become more transnational in scope. In addition to the activities of second-generation gangs, third-generation gangs also take part in kidnappings, money laundering, and large-scale extortion and racketeering schemes that sometimes transcend more than one locality.

As gangs become more sophisticated and they evolve into third-generation gangs, they tend to exact a tighter control over the areas they occupy. Mainwaring (2007) points out that they in fact, take over these areas from the state and govern them as their own. In doing so, they exert political control and influence over the state by forging alliances with corrupt state officials and manipulating outcomes in ways that are advantageous to their economic goals.

Reviewing the various typologies above, it is clear that there is a synergy and, in some cases, an overlapping of some of the various gang categories and characteristics. When taken together we are presented with a complete perspective of the elusive and varied existence of a multiplicity of gang and garrison formations. Further, applying Mainwaring's (2007) typology to the current study highlights the complex and diverse nature of the garrisons and gangs that make up the country's urban areas. The fluid ways in which generation-based gangs evolve and define themselves, not just in makeup but also in terms of spatial boundaries, allows for an analysis that takes into account the multiple garrison types and the historical context of various urban spaces. In addition, an 
assessment of the various typologies of both garrisons and gangs provides support for how and in what ways these social spaces and groupings are becoming transnational, as well as how they manage to remain resilient despite occupying national spaces. Based on the descriptions above, although Jamaica displays all generations of gangs as outlined by Mainwaring (2007), the Jamaican state is faced primarily with the dilemma of managing the more transnationally minded, and formally organized second and third-generation gangs.

\section{Power Structures within the Garrison}

Ultimately, however, an exploration of the organizational/governance structure of these criminal entities is required in order to properly understand how garrisons, and the criminal groups that reside within them have found strategic ways to modify fixed territorial spaces into blurry and fluid zones of control. For criminal entities aimed at becoming successful profit maximizing organizations, a clear delineation of managerial authority is required. The delineation of managerial authority makes it easier for them to expand into diverse and multi product/service markets, whether legal or illegal; recognize shortfalls in leadership; and to evaluate the performance and effective of its current members. Conversely, smaller, more localized criminal entities content with fulfilling basic day-to-day needs and petty crimes tend to be equally effective as more loosely structured organizations, as they have an interest to expand.

By applying a governance structure that aligns with the aims and interests of the garrison, criminal groups as non-state actors are able to take a more effortless part in criminal activity with a lower possible risk. The significance of the right governance structure is that it helps to solve problems associated with communication and decision 
making- both situational and long term- and builds higher levels of trust, commitment and loyalty within the criminal structure. In the case of the criminal groups in the garrisons of Jamaica, their organizational structures tend to be more flat. Comprising of no more than one to two managerial levels, this type of hierarchical structure is generally requires lower level members to make important decisions on the spot. It also requires a communication channel that generally runs from top - down, as well as from bottom up.

Distinct from taller organizational structures with a unidirectional top- down flow of information the flat organizational structure is ideal for smaller groupings common to the garrison. These small-scale organizations enable quick decision-making and response times between members, and require individuals to perform multiple functions and responsibilities. In doing so, this type of structure helps to effectively maintain the flexibility needed to manage multiple goods, products and services. While expansion might not always be the aim of these small criminal groups, flat organizational structures make it easy for these groups to grow rapidly if their interests change.

Civil versus uncivil Community governance systems. For scholars such as Johnson (2010), the garrison is plagued with two competing governance structures, or what she terms 'competing community-based political systems'- both indicative of a flat hierarchical organizational structure. The first governance system she identifies as the government of civil community (GCC), headed by traditional community leaders called 'area leaders' (p. 7). This governance system represents a legitimate organizational structure that is present within garrison areas. 


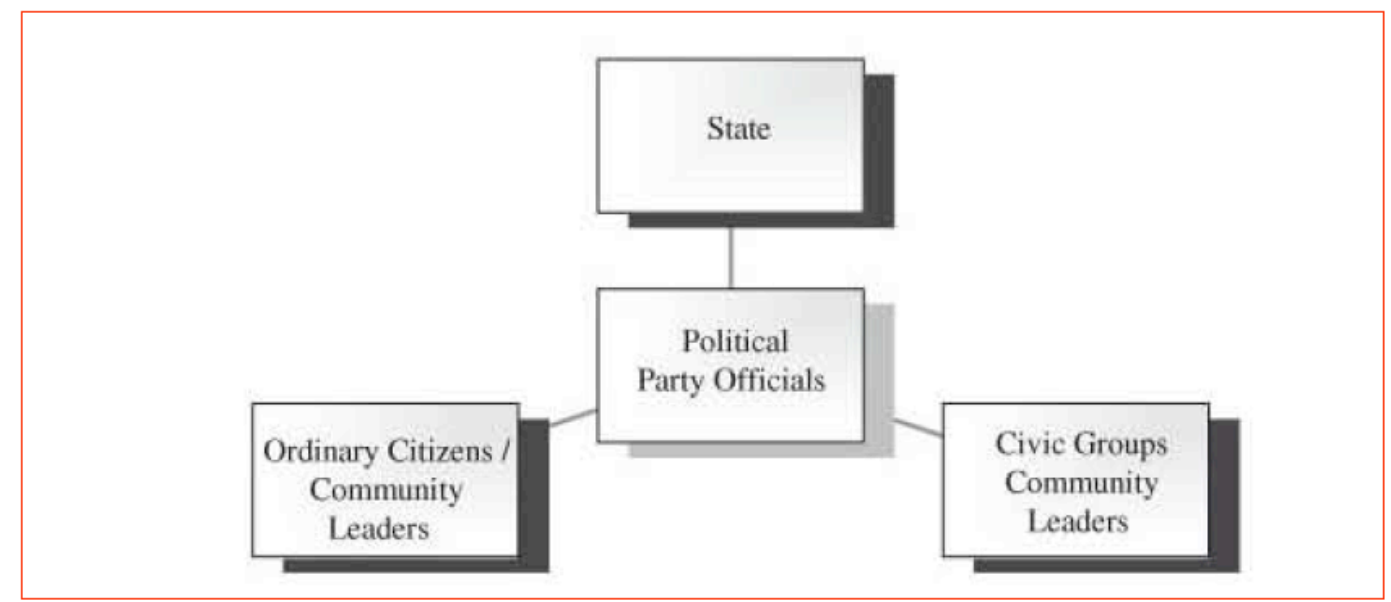

Figure 14. Government of the Civil Community

Note. Figure taken from J Johnson, H. N. (2010). Towards Degarrisonisation in Jamaica: A place for civil society. Crime Prevention and Community Safety, 12 (1), 1-23.

Within this structure, Johnson (2010) notes that the state is hierarchically located at the top, and at the center of the power distribution, while political party officials are positioned strategically to mediate between the state and the community.

The second type of governance system present in the garrison is the Uncivil Community Government (UGC). It is representative of a rogue form of leadership within garrison communities, headed by a new type of area leader called 'the don'. Johnson (2010) argues that this new type of leadership has progressively surpassed the presence and influence of the GCC since the 1960's. It, “exemplifies the cadre of prominent citizens who emerge after 1980 with menacing authority in Jamaican inner city communities" (Johnson H. N., 2010, p. 5). 


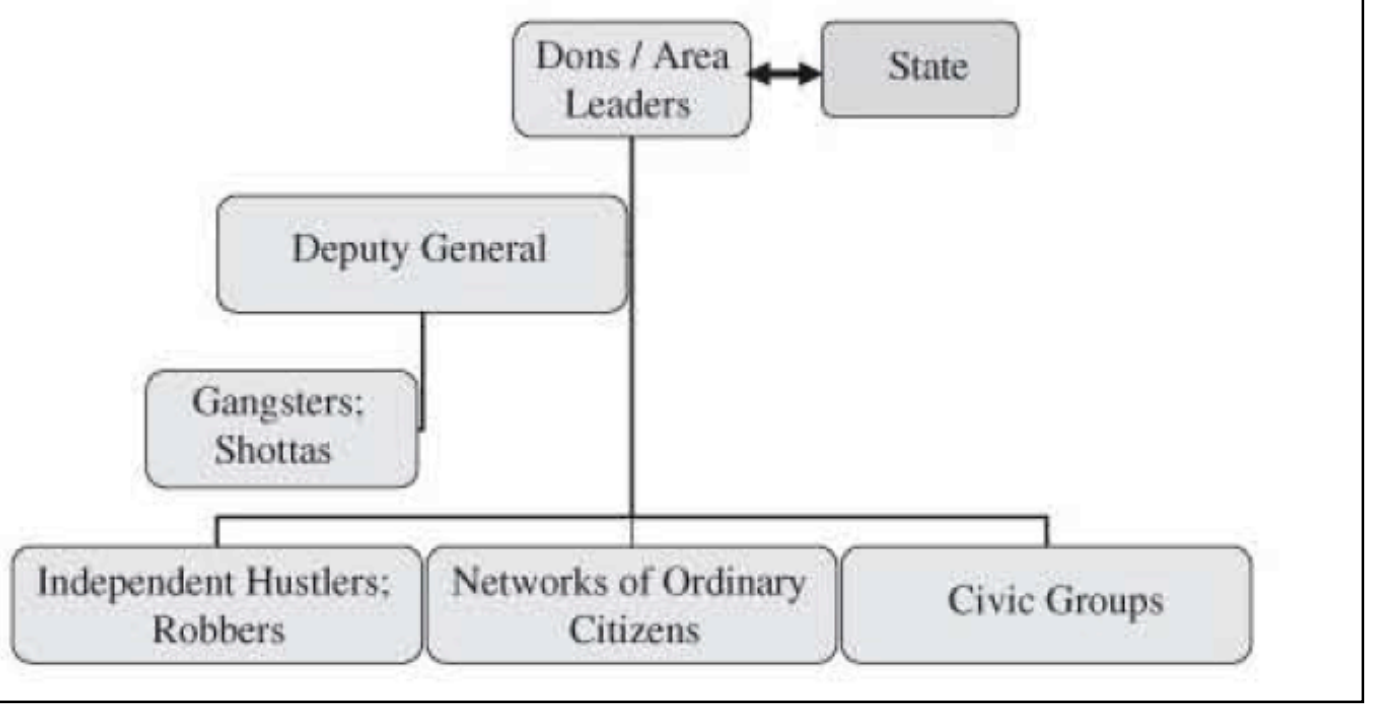

Figure 15. Uncivil Community Government

Note. Figure taken from Johnson, H. N. (2010). Towards Degarrisonisation in Jamaica: A place for civil society. Crime Prevention and Community Safety, 12 (1), 1-23.

Structured similar to mafia groups Johnson (2010) indicates that UCG system represents relatively large informal organizations, in so far that outlaw governance systems may span entire communities. Each governance structure has its own economic, security, and administrative apparatuses all located within the territorial confines of Jamaica. The don sits at the head of the organization managing several of these community-based governing structures. In her uncivil community governance model, Johnson (2010) shows the state located at the top of the governance structure. However, the state is offset to the right and alongside the don who is at the center of the power structure, and who is in control of his own security apparatus comprised of a deputy general, gangsters and shotta's. Within this structure we also find that the role of the 
political party official has become obsolete, and that the actions and interests of ordinary citizens and civil society groups are controlled and influenced by the don.

Using his wealth and political connections, the don is able to gather large-scale support to manage a community by creating a welfare system and by offering protection in exchange for the loyalty of its residents. Scholar such as; Johnson (2010), Munroe (1999), Bayat (1997), Cohen and Arato (1994) and Pietrzyk (2001), all maintain that the complexity of civil society interactions make it possible for civil society to, at times, reject its dependence on the state by organizing itself. "Beyond the official and recognized social assemblages and groupings, civil society also forges 'networks and relationships which may or may not crystallize into (formal) groups, but which nevertheless connect individuals together in some non-coercive, reciprocally purposive manner"' (Munroe 1999, p. 78 ctd. in Johnson, 2010, p. 4). For residents within the innercity communities of Kingston, forging networks and relationships with criminal groups in exchanges for resources that the state is not able to provide, is an easy solution to the socio-economic problems they face.

\section{A Transnational Perspective on Governance Systems in the Garrison}

The blurring of legitimate and illicit processes. However, in accepting that civil society is a complex mix of both formal and informal interactions, why must we conceive of governance structures within the garrison to always be competing, or to be either civil or uncivil? Interviews carried out in the current study indicate that aside from gang related power struggles for control, there are few power struggles between civil community governance structures and uncivil governance structures that taken place. 
Rather, we find a cultural acceptance or tolerance for the area leader/area don within inner-city communities.

However, tolerance does not mean that civil society is not weary of the negative effect that criminal groups have on the country and that they do not desire to be rid of them. However, it does highlight that in the interest of development goals, civil society groups both within and outside of these areas as well as the state have sought to foster alliances and relationships with informal uncivil community governance systems. One such example is found in the urban communities of Mountain View (Francis, 2013; Sinclair, 2002). Here a coalition between the Mountain View Community Council, the Social Development Commission (SDC), Excelsior Community College, the Citizen Security and Justice Programme (CSJP) and the Peace Management Initiative (PMI), in 2010, have helped to establish talk terms with criminal groups within several garrisoned areas to minimize violence and negotiate peace.

These interactions, by formal power structures, with criminal groups implicitly recognize the influence that these criminal groups have within their communities and unquestioningly solidify their role as community mediators. However, being a community mediator is a double-edged sword. On the one hand, criminal groups assume some of the welfare roles of the state in order to control specific communities so that they can carry out illicit activities without interruptions. On the other hand, as discussed in chapter 7, as a social actor, criminal groups must also maintain close ties with the formal structures they are intent on evading. Area dons must occasionally negotiate with political party constituency members and civil society groups for the interests of the community. Often times, the needs of the community, as well as the location and types of 
development that takes place within the community must be discussed with the area don, and his input weighs heavily on the success of the project.

In addition to the formal/informal role the area don plays in the community, it is also possible for them to forge legitimate and profitable relationships with the government while simultaneously carrying out illegal activity. By establishing legitimate small businesses or forming partnerships with existing legitimate companies, criminal groups are able to compete for government contracts for community projects.

Government contracts allow them to control the distribution of jobs, to control access to the development project, and to provide the area don with additional profits to disburse as he sees fit.

The influence of market liberalization on development policies in Jamaica has first; limited the amount of direct investment constituency members can invest into a community and requires greater transparency when funds are disbursed. Second, it has increased the role that the private sector can play in community development. Third, market liberalization has forced criminal groups and corrupt government officials to find creative ways to maintain clientelistic relationships. The Constituency Development Funds (CDF) discussed in chapter 7, allows constituency heads to disburse funds for community development projects to legitimate companies interested in bidding for government contracts. Within specific communities, these legitimate companies are merely legitimate fronts for the garrison's don. Although these contracts require fair bidding, it is not uncommon for other companies to drop out of the bidding process or to not even attempt to compete against a company, they know has a garrison backed criminal affiliation. As Naylor (2004) points out: 
Black markets are institutionally embedded in the legal economy. Few ships carry only contraband goods; it is probably impossible to find a bank that does nothing but launder illegal money; and virtually any underground entrepreneur with hopes of a durable commercial existence ensures that his or her illegal acts are embedded in a matrix of legitimate transactions. This integration, along with the evident tendency of legal businesses today to use ever-shadier methods, has allowed these isolated black markets that once had operated on the fringes of legitimate society to give way to a continuum within society that is colored in various shades of gray. (p. 3-4)

In the case of the former garrison don, Christopher 'Dudus' Coke, information during his extradition to the United States and his subsequent court case revealed that during his leadership of Tivoli Gardens he was on the board of directors for two companies. One was a trading company called Presidential Click that specialized in entertainment promotions and that was known for its weekly street parties and dancehall competitions (France 24, 2010). The second was Incomparable Enterprise Limited; a construction company where he and his business partner Justin Ogilvie had managed to secure JA $\$ 32$ million [US\$320,000] in government contracts in 2009 for work in and around the Tivoli Gardens Garrison (Hall, 2011). ${ }^{44}$ In the same year, Incomparable

44 Hall, A. (2011, July 13). US Bars Dudus Pal- Embassy Revokes Justin O'Gilvie's Visa. Retrieved September 22, 2013, from The Gleaner: jamaicagleaner.com/gleaner/20110713/lead/lead1.html?utm_source=twitterfeed\&utm_medium=twitter The National Contracts Commission in June 2009 approved the contracts with Incomparable Enterprises Limited for repairs to buildings in Tivoli Gardens. One of the contracts, valued at $\$ 10.7$ million, was for repairs and waterproofing to the slab roofs along the Bustamante Highway section within the Tivoli Gardens housing scheme. The other contracts, which total \$21.3 million, are for repairs to roofs at Levy Path and Seaga Boulevard, also in the community. All three were given out by the Ministry of Water and Housing through open tender. That was one of several times that Incomparable Enterprises did work for the 
Enterprise Limited also was awarded JA $\$ 69$ million [US\$690,000] in emergency

contracts for repairs to public drainage and the gully system after Hurricane Gustav in

$2008 .^{45}$

Government under the current Jamaica Labour Party administration and the former People's National Party government."

${ }^{45}$ See Government endorsements by National Contract Commission chart for Februrary 2009. Special attention to 11.02.09, funding agency- National works Agency, contractor- Incomparable Enterprises Limited http://www.ncc.gov.jm/website_files/contracts_endorsed/awards-february2009.htm 


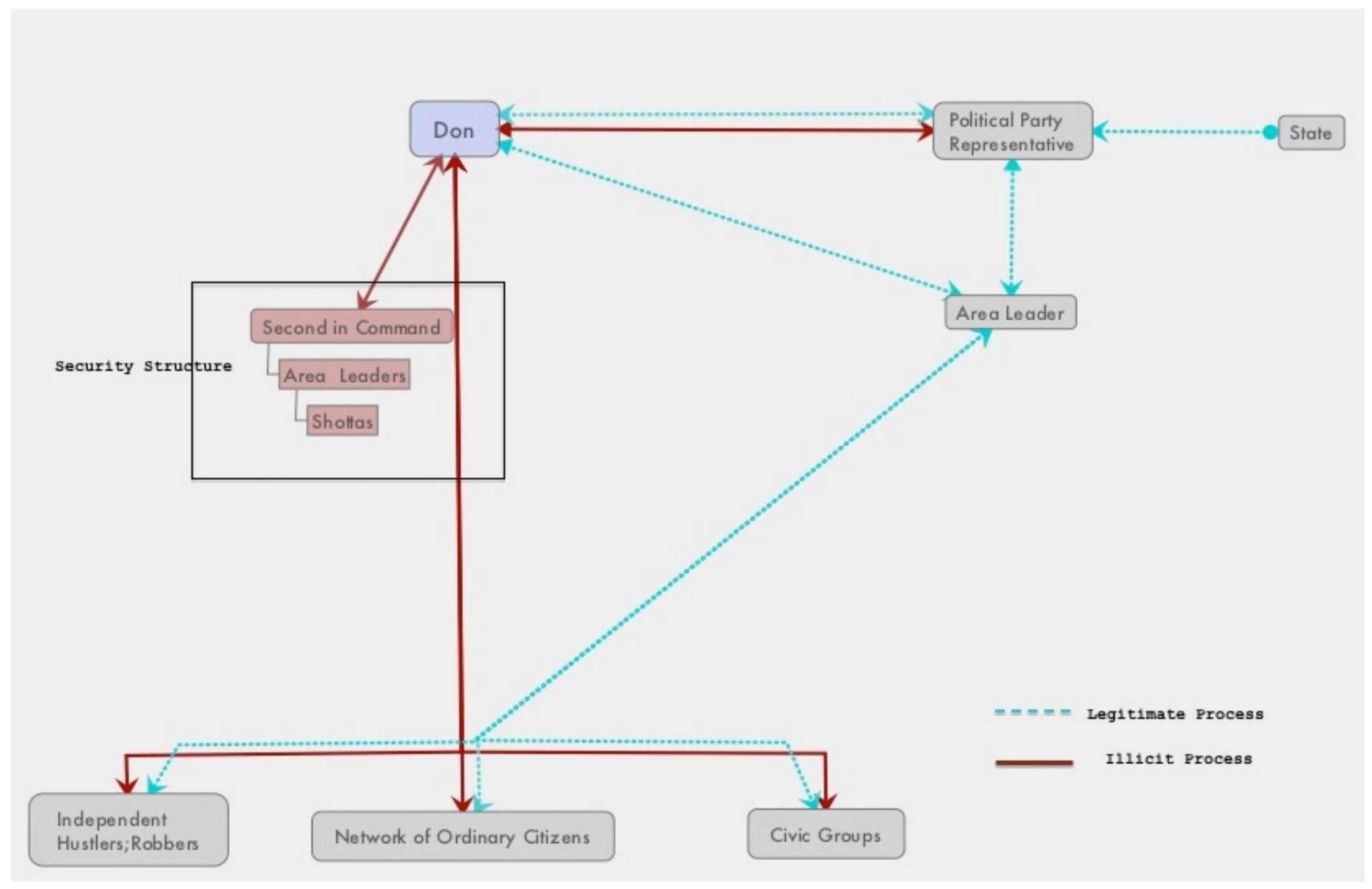

Figure 16. Transnational Garrison Governance System 
Within a transnational model of garrison governance, the don is positioned at the top, and at the center, of a flat organizational structure. As the head of this structure, it is the don's responsibility to manage both the legitimate and criminal interactions taking place within the territorial spaces he controls. Using his criminal security structure comprised of his second in command, area leaders, and shottas, the don is able to control access in and out of his territory, enforce community loyalty, as well as run and protect his criminal activities and businesses. While all garrison communities, do not necessarily have both an area leader and a don; in cases where there are both, the area leader is delegated to the same leadership level as the second in command. The main distinction here is that while the second in command manages the illegal side of the governance structures, the area leader mediates the legitimate aspects of community interactions and processes between political party representatives and the don. In cases where the don has some notoriety, the area don is critical to the outward face of community-state interactions.

By representing the interests and expectations of the don, the area leader mediated openly with political party representatives in order to negotiate the distribution of benefits to the community within a democratic state. It is generally through area leaders in collaboration with civil society groups and networks of ordinary citizens that party representatives release constituency development funds for area development. However, regardless of whether the area leader is a passive or active supporter of the don, the authoritarian and criminal power structure of the don demands his involvement and awareness of anything that takes place within his community. It is also not uncommon for the don to interact directly with political party representatives. However, these 
interactions are often times more covert as they revolve around the criminal group's role as political activists, and the exchange of political loyalty for access to other clandestine activities or services.

In the transnational model of garrison governance, regardless of the prominence of the don, the political party representative is still vital to providing the don with access to corrupt elements of the state, and to blurring the don's involvement in community development and interaction. In cases where the area leader and the don are the same person, the formal interactions between himself and political party representatives help to maintain his suspected criminal role and illegal community influence as merely hearsay.

\section{Operational Structure of the Criminal Group}

Organization versus grouping. In addition to the nature of its governance structure, the operational structure of the criminal groups residing within the garrisons is equally important to their success. For Johnson (2010), “[the Italian Mafia] has for a long time been recognized as the 'winning model' of organized crime in the world" (p. 3), and represents the model that best identifies with the Jamaican don and his criminal structure within the garrison. However, this perspective can be a bit tricky. Care must be taken comparing the operational structures of Jamaican criminal groups to the popularly recognized organized criminal groups because while we can find similarities in the behavior of organized crime groups and the behavior of Jamaican gangs, the operational structures between the two are vastly different.

Similar to the Sicilian Mafia, the Chinese Triads, the Colombian Drug Cartels, and the more modern organized crime syndicates from Mexico, Nigeria and Russia, Jamaican criminal groups behave in a like manner. According to Naylor (2004), 
organized crime groups generally take part in market-based offences; maintain a constant flow of production by forming clear channels of command; organize themselves not only to carry out crimes but also to dominate markets; seek to enhance their position by using violence and corruption to control territories, markets, and industries. Organized crime groups also set out to achieve higher profits by penetrating legitimate markets (pp. 15$16)$.

However, where the operational structure of organized groups are identified as large, complex, sophisticated, and centrally controlled hierarchical organizations that wield significant power and control, Jamaican criminal gangs are structured differently. The very notion of Jamaican gangs as large, sophisticated, and centrally controlled hierarchically groupings, conflicts with the reality that there are approximately 268 small groupings of active gangs in Jamaica's urban area, all with varying degrees of political allegiance, interests and operational goals. In no way does a look at the typologies of gangs and garrisonalized spatial areas indicate that these groupings have pool their resources together in any lasting manner. Nor have they constructed permanent alliances between specific gangs, or established a shared and coordinated business model for maximizing profits.

To be clear, criminal groups within the garrisons have formed alliances both across political parties and between competing gangs. However, these alliances have always been strategic, and related to a specific event or to a particular short-term goal. One of the earliest alliances between garrison political party factions occurred in 1978 after the infamous Green Bay Massacre. It is alleged that leaders with the then governing political party of the PNP authorized a covert military operation to neutralize a prominent 
political gang loyal to the opposing party. Having infiltrated the gang, the soldiers were able to lure the majority of its members to a shooting range at Green Bay and executed them save for a few survivors who managed to escape (Sinclair, 2008). Scholars such as Gunst (2003), Gray (2004), and Sives (2010) indicate that in the aftermath of this event, urban gangs within the garrisons for the first time recognized just how expendable they really were to the leaders of the political machinery. Leaders within the warring gangs spearheaded a truce between political gangs regardless of political affiliation. "A Central Peace Council (CPC) was created and comprised people from the various communities involved in the initiative who met and elected a Peace Advisory Committee which monitored the recommendations and proposals for building the peace" (Sives, 2010, p. 106). However, by 1978 , the truce began to crumble and by the 1980 general elections, violence and warring over resources between garrisons and gangs had resumed.

As social actors, dons within warring communities have also at times forged temporary alliances in order to assist with community development projects, or to renegotiate territories or safe zones in the interest of profits. In 1996, JLP don Dudus from Tivoli Gardens and the PNP don Zekes from Mathews Lane, orchestrated a peace agreement that first assisted with the remodeling and expansion of the Kingston Public Hospital located in close proximity to the two warring garrison zones. The peace agreement was able to allow workers from varying areas free access through these garrison areas en-route to the hospital, and it also allowed for the safe passage and protection of building material transported to and stored on the job site. 
Temporary alliances between criminal groups in the garrisons in addition to facilitating community development and assisting the state in its ability to carry out its function within contested areas, have also aimed at tempering the level of violence when it threatens to affect the economic interests of the criminal groups. Rao \& Ibanez (2003) citing Duncan $(2001)^{46}$ point out that:

The agreement [aimed at assisting the renovation of the $\mathrm{KMH}$ ] is [also] better characterized as a strategic alliance, which carefully demarcates areas of control. Preliminary fieldwork [carried out in their study] seems to suggests that Zeke was allowed to control the areas bordering greater Kingston - and thus access to jobs and other economic opportunities - while Dudus was granted control over the wharfs - and therefore to the drug and gun trade (p. 803).

A clear understanding of the operational structure of criminal groups within Jamaica's urban areas would suggest that rather than criminal organizations, the garrison is comprised of, " a loose fraternity of like-minded souls who freely formed alliances and partnerships and just as freely dissolve them" (Naylor, 2004, p. 3). These groupings play a critical role in the success of these small criminal groups. While their criminal behaviors and activities are similar, the alliances they form are tactical, they allow for quick responses, and are easy to break away from and replace [although not convenient] when under threat. Tactical alliances between like-minded groupings allow them to behave like a larger, coordinated criminal organization, yet their individual groupings and differing interests protect the identity, location, or activities of the collective and makes it

\footnotetext{
${ }^{46}$ References early edition of 2008 work with M. Woolcock. See Duncan-Waite, I., \& Woolcock, M. (2008). Arrested development: The political origins and socio-economic foundations of common violence in Jamaica. University of Manchester Press.
} 
difficult to completely eliminate all garrison groupings. As founder and Executive Director of the Peace Management Initiative Horace Levy (interview July 27, 2012) pointed out, in the wake of the Tivoli Incursion May 2010 amid heightened state control that followed, the garrison as we know it is dead. Centralized and authoritarian controlled communities like Tivoli that have the power to deny the state access within its boundaries are on the decline. However, despite garrisons undergoing major changes there are several decentralized garrisons still in existence responding to transnational activities such as lottery scams, violence for hire, and drugs. On a larger scale - moving from the local to the global the decentralized nature of criminal groups can be seen in the cyclical nature of drugs and arms trafficking. Where, when one trade corridor becomes restrictive another one gains prominence; as well as in the multiplicity of criminal actors and the ever-changing sequences of interactions uncovered by law enforcement around the world. 


\section{Summary}

Rather than thinking of garrison groupings as criminal organizations, garrisons are more indicative of network-based groupings with flat hierarchical structures. Employing a combination of hierarchical and network structures, garrison groupings do not need to be highly sophisticated in order to evade the law, successfully profit from illegal activity, establish a monopoly within a specific market, or to coordinate and mediate political interests.

A flat hierarchical structure allows these groupings to identify and formalize various levels of commitment to the group. A person's role as a don, or as an active member of the gang (second in command, general, shotta), or even as an active or passive supporter or community resident, determines access to information, visibility in the gang, and the degree of autonomy to make decisions.

Similarly, the diversity in garrison and gang typologies and organization further allows for a fluidity of interactions that helps them to maintain a high degree of security without the need for high levels of information technology. Framed by a clientelistic political system, garrison groupings may organize or evolve based on family ties (The Shower Posse donship legacy), by geographical location (Mathews Lane- maintaining border between two distinct political constituencies), or by a specific function or purpose (Arnett Gardens- created in opposition to Tivoli Gardens). As one community leader (interview, July 30, 2012) revealed, power in the garrison varies depending on who is in control and by how that power is shared. There might be an entire garrison under the control of one person, or there might be one garrison carved up into several communities and headed by different individuals. For this interviewee, " the garrison community of 
Dunkirk is carved up, and before the incursion Denham Town and Tivoli Gardens were considered one and you could look at some other JLP [Jamaica Labor Party] controlled area[s] and still see them as one". With a shared criminal behavior, networks allow garrison groupings to maneuver their interactions as it appeals to a shared interest; whether to collectively demonstrate for a cause, to form temporary cross party alliances, or to form fleeting coalitions based on political loyalty.

Dependent on the relationships and history between specific gangs and garrisons, networks across garrison groupings and between other members of society may be structured similarly, to how a chain is connected. Several garrison groups are linked together by a stream of information that travels back and forth between the groups. The flow of information may be the only way in which these groups are connected, as each group although responsible for a specific aspect of illegal activity, may not have any knowledge of the overall running of the entire operation or event. Network chain structures are ideal for groups who take part in criminal activities such as smuggling or money laundering, and are representative of the distribution channels discussed in chapter 6 regarding violent illegal goods such as cocaine that start with the fisherman and range through a complex network of retailers and wholesale distributors to exporters.

In addition to a chain structure, garrison groups also employ a wheel style network of interactions within and across its security, economic, and or financial sectors. At the center of this wheel we find the main decision maker who is often times the don, and at each node projecting from the center a specific role is assigned and micromanaged; allowing each point some autonomy, while maintaining communication. Referring back to the transnational garrison system [see figure 16], we can identify the 
second in command and the area leader as two separate nodes connected at the center by

the don [see figure 17]. 


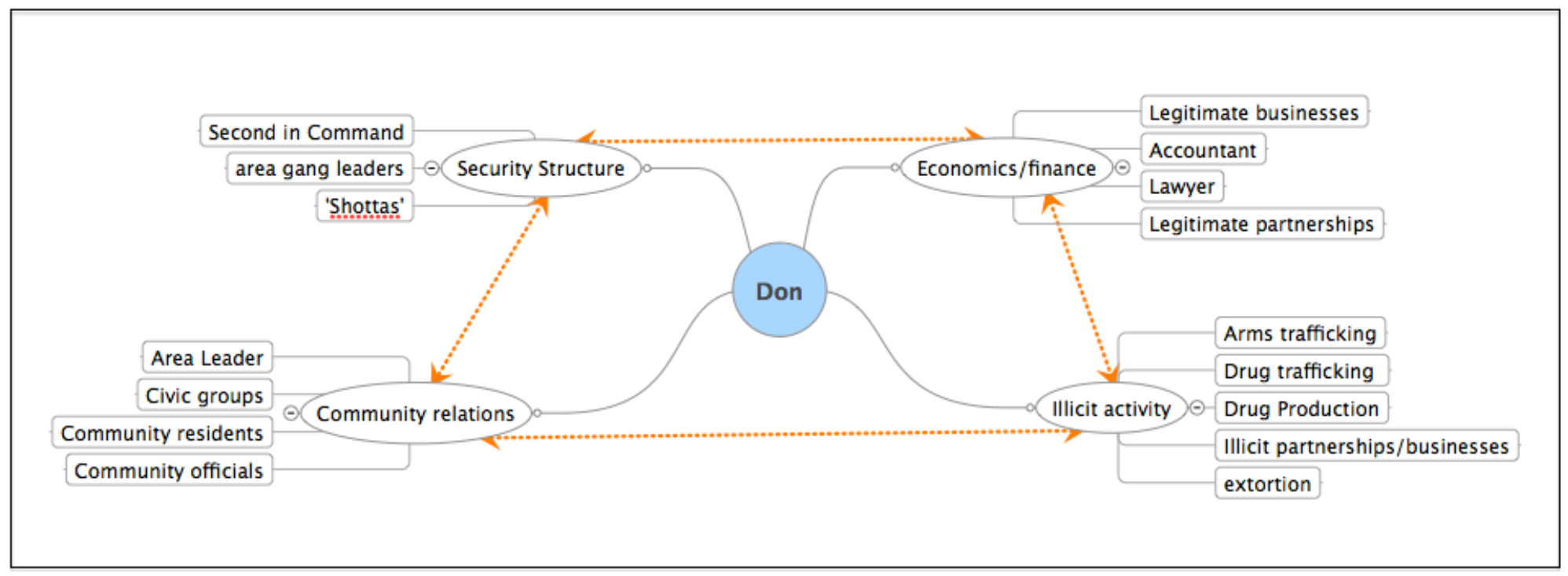

Figure 17. Transnational Garrison Operational Network Structure 


\section{CHAPTER 6}

\section{TRANSNATIONAL VIOLENCE}

\section{High Levels of Violence}

While the level of violence in Jamaica has remained relative high, what has changed since the 1980's is the main causal factor associated with this violence. Leading up to the 1980s elections, high levels of violence were predominantly associated with politics; today high levels of violence are linked primarily to urban street gangs. This chapter argues that criminal groups within the garrison use violence and corruption as tools to 1) restrict the access of the state and non-residents from entering the garrison, and 2) to protect, maintain, and expand their criminal activities. According to the 2009 National Security Minister Senator Dwight Nelson, Jamaican gangs were responsible for as much as $80 \%$ of all major crimes on the island, with roughly $90 \%$ of the country's homicides recorded as gang-related (Spaulding, 2009; Jamaica Observer, 2009). By 2012, the Jamaican government indicated that there are estimated 268 active gangs operating throughout the island (Ramsey, 2012).

Between the 1970s and the 1990s, Jamaica experienced civil service reforms. These reforms occurred first, as prerequisites for loans and aid from multilateral agencies within the context of structural adjustment programs. Second, civil service reforms occurred in response to a growing public desire for the increasing efficiency and effectiveness of the public sector, within a changing economic climate (Tindigarukayo \& Chadwick, June 1999). Third, some scholars such as Sives (2010) contend that the drive for electoral reform was also a result of the rapid escalation of political violence during 
the late 1970s right up until the 1980's elections. This is because the violence of the 1980s election scared the political parties: "both political parties were fearful of the return of political violence which had spiraled out of their control in 1980" (Sives, 2010, p. 119). By the end of the 1980's, political parties were taking note of how these armed, empowered urban 'political fighters' were now using weapons, and the entitlement given to them by the political parties, to branch out into other forms of violence related to drugs and gangs.

Since the push for electoral reform by the Jamaican civil society in 1986, and support for reform by political parties in 1993, there has been a decline in politically motivated violence in Jamaica. Civil society driven organizations such as the Electoral Advisory Committee (EAC), the Electoral Office of Jamaica (EOJ), and Citizens Action For Free and Fair Elections (CAFFE) have focused on demanding legislation, ensuring free and fair elections. ${ }^{47}$ These legislations called for security of the poll and increasing sanctions against offenders, hence cutting back on the supply of resources to these communities for political support (Sives, 2010). However, despite reductions in politically motivated violence, the murder rate in Jamaica remains among the highest in the world. (Levinson, 2002; UNODC, 2007) ${ }^{48}$ It has also consistently held the highest per

\footnotetext{
${ }^{47}$ Good governance was one of several components under civil reform that incorporated the active participation of several civil service associations into government decision-making. Local support for good governance process insisted that political bureaucracies needed to be decentralized in order for civil society to have a greater say in the formulation and implementation of policies that directly affected them. Good governance and civil society reform also demanded a greater transparency in the electoral system.

${ }^{48}$ Levinson, D. (2002). Encyclopedia of Crime and Punishment (Vols. 1-4). Thousand Oaks, California: Sage Publications Inc. The murder rate in Jamaica rose from 21.4 per 100,000 of the population in the 1980's, to 27.7 in the 1990's.; UNODC. (2007). Crime, Violence, and Development: Trends, costs, and policy options in the Caribbean. Report No. 37820, A joint report by the United Nations Office on Drugs and Crime and the Latin America and the Caribbean Region of the World Bank. Between "2003 to 2005 , Jamaica's homicide rate rose from 36 to 58 per 100,000 before falling to 49 per 100,000 in 2006. While the
} 
capita homicide rate for the Caribbean since 1990- 2010, with Guyana holding the title briefly in 1991.

While civil reforms helped to minimize the potential for political violence and fraud, it has also helped to encourage the expansion of garrison violence to other more lucrative markets. Good governance and electoral process reforms now limited the inflow and type of resources going into these communities. Yet, it did not alter the relationship between political parties and garrisons. Although political loyalty within the garrisons to specific political parties remains in tack, civil reforms added greater complexity to the interaction between the political parties and the garrison. During election-time, political parties were able to find ways to increase the flow of resources in these areas in exchange for votes, and in between elections, garrisons used politically gained resources to turn to other forms of violence to maintain, if not increase the flow of resources that they had become accustomed to.

\section{The Changing Nature of Violence}

Violence is a key feature of Jamaica, characterized as a developing state constrained by global, international and local forces. Violence is a byproduct of the development of politics in Jamaica (Figueroa, Harriott, \& Satchell, 2008), where communal patterns of voting (Sives, 2010) and the forging of political identities along spatial boundaries (Gray, 2004) resulted in the outflow of structural violence throughout urban communities within Jamaica. It is within this context that the Jamaican state has justified the institutionalization of criminal power structures known as garrisons. Political

decline from 2005 to 2006 was encouraging, by end of that same year homicide rates spiraled back up to 61 per 100,000 and peaked at 63 per 100,000 in 2009 before declining to 50 per 100,000 in 2010. 
tribalism, however, is not the only causal factor of violence within the Country's urban communities. Since the 1980's, urban gangs located within the garrisons have assumed a more influential role in the distribution and use of violence.

Within the context of structural adjustment policies, electoral reforms and the migration of key political enforcers, urban gangs have reconstructed the meaning and the use of violence. In the midst of a failing economy and radical changes to the economic structure, Jamaica experienced one of the bloodiest elections in its history--the election of 1980. The fierce ideological divide between socialist People's National Party (PNP) and conservative Jamaica Labour Party (JLP) erupted into widespread gang violence across the Island (Campbell, 2010). Urban gangs were blatantly disrupting political rallies and firing on campaign motorcades. When the dust settled, approximately 800 murders had been committed, with the majority of these deaths occurring within garrison communities. The JLP won the election with a landslide victory of 51 seats to nine (Helps, 2012). Primarily in response to the level of violence, civil society groups within the Country pushed for electoral reforms in the mid to late 1980s. Concerned with the uncontrollable nature of violence, and the increasing power of the urban gangs, political parties also supported these reforms. To further get a handle on the gangs, and in the interest of plausible deniability, Thomas (2011) points to an observed push for, "the relocation of political party 'activists' from Jamaica to the United States by party leaders after the bloody elections in 1980."

With the elections over and the JLP in power, the government now turned its focus to the failing economy. The IMF imposed structural adjustment policies implemented in the 1980's lead to a decline in state resources, as the primary role of the 
state shifted from providing welfare services to its citizens, towards creating and preserving an institutional framework that supported the turning over of the local economy to private interests, free markets, and free trade. Ultimately, although the parties have found ways to reroute the supply of resources to garrisons, for example, through political contracts, the resources provided by political parties to the garrisons dwindled. Urban gangs located within the garrison have used violence as a means to provide themselves and their communities with a more consistent flow of resources given the temporal nature of electoral politics and the scarcity of resources available. Violence has allowed the criminal elements residing within the garrisons the means to access and protect new interests in the many illicit global markets fueled by the new neoliberal economy.

\section{Globalization's affect on the Nature of Violence}

Global forces such as the international trade in drugs and arms and neoliberal economic policies have contributed to a reconceptualization of violence to include a transnational component. For Rotman (2000), globalization has modified crime and other variants of violent by creating a space for violent illegal activities to increase in scope and in intensity. Globalization has allowed localities access to a wide range of violent tools, as well as created incentives within these localities to carry out violent and criminal activities.

Criminal groups, residing within Jamaica's garrisons have increasing access to advanced technologies in communications and transportation. They find themselves within a global structure where the restrictions, regulations, and significance of strong state borders as they relate to mainly economic and social variables have been reduced-- 
creating a space for criminal groups to operate outside of the realm of the state. It has allowed criminal entities to create a "market in violence" (Rotman, 2000). Expanding market shares, and the reality of a vast market waiting to be captured, has led to the need for criminal groups to protect their investments. Increasing competition among these non-state actors has ushered in an increase in violent activities such as trans-local turf wars, and the exerting of force on state officials and agencies during times when state response is perceived as a direct threat to private illicit interests.

Violence rooted in the garrison. Within garrisons, Jamaican gangs trade homogenous community votes, political violence, and a loyal political support base in exchange for guns and for the space to carry out criminal activities. Through profits earned from the drug industry garrison leaders are able to bribe and pay off politicians, members of the police force, and legitimate businesses in order to ensure that the transport of their illegal products occur at the lowest possible risk. Access to these illegal markets and weapons has reduced the garrison's economic dependence on the state and minimized the level of political violence. This same access has led to an influx of crime and violence related to drugs and other criminal activities. Violence is exploited as a way of protecting resources obtained from both political and apolitical means.

Notwithstanding the spatial concentration of violence within garrison communities: violence surround[s] [urban residents] in and around Kingston. It define[s] where we [go] and when; it structure[s] the degree to which we follow laws, such as stopping at red traffic lights in certain areas after dark; it generate[s] a particular kind of alertness... (Thomas, 2011, p. 2). 
Structural violence has become a normal part of the Jamaican society (Harrison 1997) and political violence and violent criminal activities are rooted within poor urban areas (Harriott 2008) such as Western Kingston (Chevannes, 2002). In a 1997 study conducted by the World Bank, Moser and Holland reveal that residents within four garrison communities identified six different types of violence; these include, political, drug, gang, economic, inter-personal, and domestic. Despite their differences, residents among the various communities in the study, ranked gang and gun violence as the most serious forms of violence, followed by rape and drug violence (Moser \& Holland, 1997, p. 22). Further, "residents of the poor urban communities in [the] study perceived themselves to be at war. They showed it not only in the way they conducted their daily lives, but even in the language they used to identify the different types of conflicts in which they were involved" (Moser \& Holland, 1997, p. 22).

The shift in the nature of violence from political towards gang and drug related violence, has allowed violence occurring at the local level to now entail a transnational component. Both spectacular and everyday violence has become a tool that has provided " [individuals with the ability to] transform space without necessarily going anywhere, [allowing them to] alter hierarchies of status and influence in particular localities" (Thomas, 2011, p. 8). Evidence of the transnational nature of violence as a tool, is found easily within several poor urban localities around the globe where the poor publically legitimize criminal actors. As a prominent community pastor (interview, July 26, 2012) commented: "in the early days it was the politicians who supplied the gun and the bullets but after a while the tables turned. Suppliers soon became the 'friends' who had migrated to England, America, Canada who had now become the main financiers of benefits to 
residents within the garrisons." Working closely with individuals within garrisons, the pastor pointed to situations where, "guys were making phone calls and dictating who was to be killed and who was to act because they were the ones sending the 'barrel', sending the money at the end of the month supporting [area gangs]--whoever paid the piper called the tune." The changing nature of violence was re-enforced by a more specific story told by the pastor of a gangster who went into a bordering area and killed somebody. When the area politician approached the killer, the killer informed the politician that it was his bullets bought by his money and therefore he could fire his gun at anyone wherever he wanted to. The retelling of this story highlights the power shift that has taken place between political officials and criminal entities within garrison areas, as well as the changing nature of violence.

Although violence in Jamaica is primarily taking place locally within garrison communities and between criminal gangs, the nature of violence is a direct result of the global markets and activities in which Jamaican gangs are interested in doing business. To maintain a share and to increase the profits earned in these global markets, local gangs use force to protect illegal goods that are manufactured, processed and sold in local markets. They also use force and communal violence to assume influence within specific communities by generating conditions of fear as a 'way of life' among residents, and by taking on some of the functions of the state. As a University of the West Indies professor (interview, July 26, 2012) indicated, power in the garrison is organized first around the means of coercion and second around the ability to distribute scarce benefits in the form of benevolence — school books for children and bus fare-which forces people to become clients of the don. A third way in which he identified the organization of power is 
through the dispensing of garrison justice where the person within the garrison comes to "value" the rules established by the don including the fear of being murdered and other forms of violence. Finally, force is also used to frame the complex societal interdependence between criminal non-state actors from the garrisons and representatives of the state allowing criminal gangs access to distribution channels for their goods and activities. The success of Jamaica gangs has hinged on its ability to convert violence into a product that is focused locally, yet reflects the expectations, standards, and norms of the global market and products to which it is tied.

Measurements, such as the Global Corruption Perception Index (CPI) clearly reinforce an understanding of a complex dynamic that exists between the government and criminal sectors in the society. According to statements from the Office of the Contractor General, "in [the last] ten years, Jamaica has never scored higher than 4.0...where a score of ten is perceived to be least corrupt and one is most corrupt" (Jamaica Observer, 2011a).

Table 3. Global Corruption Perception Index Data

\begin{tabular}{lll}
\hline & Jamaica & \\
\hline Year & Rank & Score \\
2002 & 45 & 4.0 \\
2003 & 57 & 3.8 \\
2004 & 74 & 3.3 \\
2005 & 64 & 3.6 \\
2006 & 61 & 3.7 \\
2007 & 84 & 3.3 \\
2008 & 96 & 3.1 \\
2009 & 99 & 3.0 \\
2010 & 87 & 3.3 \\
2011 & 86 & 3.3 \\
\hline
\end{tabular}


Note. Adopted from Transparency International Corruption Perception Indices http://www.transparency.org/research/cpi/overview

In fact, in an October 27, 2010 article in the Jamaica Observer there was a sigh of relief expressed in Jamaica, "improving 12 places on the Corruption Perception Index from the $99^{\text {th }}$ place the Caribbean nation occupied last year." The article went on to say that the current ranking was a mere, "three places shy of Jamaica's best $-84^{\text {th }}$ place two years ago" (Henry P., 2010). As the Private Sector Organization of Jamaica (PSOJ) point out in their 2010 National Security Policy Paper:

The leadership of both political parties has engaged in morally confusing behavior. While voicing concerns about crime and proffering innumerable 'anti-crime packages', they have been involved in high profile relationships with known and suspected criminals; and worse, they have been supporting these criminals with state contracts funded by our hard-earned taxes (p. 3).

Given the disparities between policy and reality, it is argued that the political culture of the urban poor in the Jamaican society is a result of the patterned distribution of income and wealth in the society. In part, its political culture is based on how this distribution is tied to race and the social distance between the poor, and the rich. As University of the West Indies Lecturer and Gleaner Columnist Robert Buddan (interview, July 19, 2012) pointed out: "Jamaica's civil society tends to be class-based. [As such] what rights you choose to advocate and how you do it might vary depending on what class you are from." In this way, the political culture of Jamaica accepts the barter of votes by communities in exchange for material resources and recognizes political mobilization as a community process (Figueroa \& Sives, 2002). These clientelistic identities and high levels of 
corruption were reinforced by the war for power and political spoils that developed during the early anti-colonial politics of the nationalist movement in the early 1950's (Gray O. , 2004).

More importantly, the under sourced security programs, the slow-paced policymaking, the focus on problem solving versus prevention, and the lack of accountability and transparency, all speak to the increasing transnational interactions that take place between criminal entities within garrisons and the state. The Jamaica state is not carrying out anti-corruption/anti-crime policies in a vacuum. Rather, the issues, processes, and policy goals brought to the table, are framed constantly by the actions of criminal entities within garrisons. The behavior of government regarding public sector corruption is further defined by complex societal interdependence and bargaining with non-state actors.

According to Mark Shield (interview, July 18, 2012), the former Deputy Commissioner of Police for Jamaica (2004-2009), it is common for political party officials to legitimize 'donship' by giving dons a seat at the table when it comes to discussing issues of community development. Referencing the organization of an upcoming national event, Shields indicated that he was aware of the event organizers having dialogue with local criminal dons to negotiate their role in providing security for the event. Commenting on this level of bargaining and negotiations he said: "I have no problem with so called "community leaders" coming to the table, but I don't like them doing so with a gun under the table. If they are prepared to put their guns on the table and have [them] destroyed and then form part of a legitimate community then I have no problem with that, but my problem at the moment is the hypocrisy around it; that 
Members of Parliament and other legitimate people in society are prepared to go into dialogue with dons."

\section{Exporting Violence- "Brand Jamaica"}

Not only is violence rooted within garrison communities; but also this particular brand of 'Jamaican' violence has roots in countries outside of Jamaica. As Thomas (2011) explains:

The emergence of Jamaican gangs is explicitly theorized as a transnational phenomenon...Individual gang members move between Jamaica, The United States, Britain, and sometimes Canada, and gangs themselves have branches in cities throughout their international networks. Drugs are moved across borders in an effort to develop the greatest profits, and so on. The violence associated with these gangs is also transnational; it is one commodity among many that circulates between Jamaica and its various Diasporas. Like that of other commodities, the consumption of violence generates an experience that then marks an entire potential market. We might therefore think about the consistent representation of Jamaican gangs as excessively, spectacularly ruthless as a kind of 'branding' process in which Jamaicans successfully mobilize one of their so-called natural resources (a cultural proclivity for violence) to generate an important niche for themselves within emergent global capitalist markets. 'Brand Jamaica' thus not

only includes such commodities as reggae and Rastafari, sun and sand, but also a terrible tendency towards uncontrollable, culturally reproduced violent behavior. (p. 74) 
Distinct from the use of violence induced by governments and other state actorswhether in their quest for economic gain or for protecting state interests- transnational violence is established as part of the market interactions that take place between non-state actors. As scholars such as Klare (2002) and Moyo (2012) argue, the control of resources has always been, and remains, an essential part of government strategies aimed at ensuring the survival and prosperity of the state. Within oil rich countries in Africa and the Middle East, state actors, at times, utilize force as a means of securing these resources. Iraq's invasion of Kuwait in 1990 in an attempt to acquire Kuwaiti oil (Seita, 1997), followed by the Persian War where the United States sought to protect their own oil interests in the Middle East by responding to Iraq's invasion of Kuwait (Klare, 2002) are prime examples of how state actors have utilized violence. Even in instances where state actors have exerted violence on non-state actors, the use of violence is primarily a means of providing security for, and governing populations within, a state. For non-state actors, the use of violence is tied to the interactions that take place between buyers and between sellers in a specific market, and it is associated with the nature of specific market commodities (Sieta, 1997).

Violence as a transnational commodity. Transnational violence is a commodity. Violence is also a commodity that is packaged alongside other commodities violent in nature. Seita (1997) establishes that:

Illegal or not, the demand for (and supply of) particular commodities can often be a contributing cause of violence, whether narrowly defined to mean death or serious physical injury to human beings, or broadly defined to include 
psychological harm to human beings and physical harm to other living organisms and the environment (p. 637).

In the case of Jamaica, criminal elements residing within garrisons generally associate their 'brand' of violence with, violent illicit goods such as drugs, weapons, and extortion. These commodities incorporate violence as part of its market value, and are instruments of violence themselves. Suppliers use violence to obtain process, protect, and distribute illegal commodities (Seita, 1997). Further, these suppliers are potential buyers in other illegal markets who use violence to obtain funds to buy the illegal commodities they wish to market.

Cannabis: As stated earlier, Jamaica is the Caribbean's largest producer and exporter of cannabis, as well as one of the four major drug transit country in the Caribbean for South American cocaine bound for the United States, Canadian, and European markets (Sullivan, 2010). Given the location of Jamaica, its diverse fauna, its nutrient rich soil, and its humid climate, cannabis presents itself as the ideal crop for low-income farmers in search of a low cost illegal product that is highly profitable. Prior to the 1990s large-scale cultivation of cannabis took place in the wetland areas of western and central Jamaica, however the massive drug eradication programs spearheaded by the United States during that period, pushed farmers towards finding new methods of cultivation if they wanted to continue to reap profits from the drug. After the 1990s, farmers realized that the cultivation was still viable on smaller plots of land and in other topography such as 
remote highland areas in the Blue Mountain region of eastern Jamaica (Haughton 2011). ${ }^{49}$

Cannabis production is not capital-intensive, nor does it have large economies of scale. Rather, the ability to have multiple products from one crop adds value to the product at each stage of processing. The cultivation of cannabis is conducive to smallscale mixed cropping agriculture, allowing farmers to grow it alongside legitimate products. Mix cropping allow the farmer to hide his crop, and it allows him to grow cannabis as a sideline product to supplement his income. There are three main forms of cannabis produced and exported in Jamaica. These forms are:

1. Marijuana-dried leaves and flower buds coarsely ground and oftentimes

a. Mixed with tobacco to make a 'spliff'

b. Smoked in a water pipe called a bong

c. Put in an emptied out cigar casing to make a 'joint' or "blunt"

d. Used in cooking to bake cookies or cakes, or consumed as a tea

2. Hashish or Hash (Jamaican Gum)- a resin that is secreted from the plant before it matures in a sticky form. The resin is separated from the plant, then roughly formed into cubes or rocks, and finally dried. This resin has naturally higher levels of 9-delata tetrahydrocannabinol (THC) than marijuana and is found coating the plant in abundance when the plant is grown in hot regions. Like marijuana, hashish can be smoked, eaten, or vaporized. It is more compact than

\footnotetext{
${ }^{49}$ Griffith, I. (1997). Drugs and Security in the Caribbean: Sovereignty under siege. Penn State University Press, p. 34. In some instances, marijuana farms are located in areas as high as 2500 feet.
} 
marijuana, it stores better, and is easier to smuggle. It is also more expensive than marijuana.

3. Hash oil (Honey Oil)- The most potent and purer levels of THC can be found in hash oil, which is hashish that has been mixed with "one of a number of industrial solvents, such as butane, hexane, grain alcohol and denatured alcohol, naphtha, and various mixtures of these chemicals. Solvents are selected based on their ability to evaporate completely and cleanly, leaving no chemical residue, as well as which substances they more readily dissolve." ${ }^{, 50}$ This oil is "commonly smoked using hot metal blades or plates, inhaled using specially designed vaporizers, or smoked from a bed of ashes. ${ }^{, 51}$

Given the location of Jamaica, its diverse fauna, its nutrient rich soil, and its humid climate, cannabis presents itself as the ideal crop for low-income farmers in search of a low cost illegal product that is highly profitable. It is a workable product that entails simple technology, low start up costs, requires little supervision, promises low economies of scale, and that is highly responsive to location and climate. Further, the ability to have multiple products from one crop adds value to the product at each stage of processing. Money earned from the resin collected from the plant before it matures, to produce hashish leads to a product that sells for slightly more than the dried and cured marijuana alone. The same happens with hash oil. Given the additional processing beyond hashish, the price of hash oil also is affected by the slight danger that the mixing of solvents may

\footnotetext{
${ }^{50}$ See nationmaster.com encyclopedia on honey oil

${ }^{51}$ UNODC. (2009). Why Does Cannabis Potency Matter? World Drug Report 2009 Series. The average marijuana plant according to the UNODC contains 5\% THC content. Depending on the genetics of the marijuana the THC content in hashish can be as high as $20 \%$. In terms of cannabis oil, the THC content, being more concentrated can surpass $60 \%$
} 
result in, as well as its scarcity in the market. Despite primarily grown in the countryside, in areas that tend to be inaccessible to vehicular transport, cannabis is also grown and it is readily available in all fourteen parishes of Jamaica (U.S. Department of State, 2012). It is generally grown and packaged for distribution within rural areas and then makes it way to other rural and urban areas through several distribution channels, where it is redistributed in other forms, either for local sales or for exportation. The criminal nature of cannabis along with the intricate networks of supply and demand, require that this market value of cannabis incorporates a level of violence that allows suppliers to protect the value of product and their share of the profits.

Cocaine: With the Jamaica government waging war on cocaine and other drugs in 1989, under Prime Minister Michael Manley (Williams L. , 2004), cocaine activities in Jamaica have remained limited to the transshipment of the product and to the processing of crack cocaine. A business partnership between cocaine and cannabis was created in the 1990s, because of the increasing competition for control over drug markets, greater access to global markets, and potential new avenues of profit. The combining of cocaine shipments with shipments of cannabis coming out of Jamaica was a strategic alliance, according to Haughton (2011) that first, allowed Jamaican drug traffickers to diversify their share in the U.S. drug market by expanding into crack-cocaine. Second, it allowed a more intricate partnership to be forged between Jamaican drug traffickers and the Colombian cartel. ${ }^{52}$ Third, the U.S backed drug eradication programs at the time focused

\footnotetext{
${ }^{52}$ Haughton, S. A. (2011). Drugged Out: Globalisation and Jamaica' resilience to Drug Trafficking. University Press of America. Haugthton points out that drug enforcement policies forced the restructuring of criminal organizations, and created a more important role for Jamaican drug trafficker in relation to the Colombian cartels. Were previously Jamaican gangs were just transshippers, now they contribute access to information and know how as specialists in distribution.
} 
primarily on cannabis. Transshipping cocaine and the processing of crack cocaine gave Jamaica drug traffickers another means of generating huge profits. The packaging of cocaine and crack cocaine was less bulky compare to that of cannabis, and the higher potency of cocaine and crack cocaine make the increased risk appealing (Haughton, 2011, p. 64). In the last two decades, the networks in place for the cultivation and distribution of cannabis have not pushed for a shift from solely transshipping cocaine, to the local cultivation and manufacturing of the drug in Jamaica- this has not been from a lack of trying (Haughton 2011).

There have been few-recorded successes of the cultivation of the strains of coca plants, in Jamaica, that have yielded high enough levels of the cocaine alkaloid. The only known recorded case of the highest level of cocaine alkaloid found was in 1989 at $0.76 \% .{ }^{53}$ With the average cocaine alkaloid content in coca leaves ranging from $0.1 \%$ to $0.9 \%$, this one case proves successful. However, this success has been small scale, location specific, and not replicable in other areas; thus making cocaine production in Jamaica impractical.

While the coca plant can be found in a variety of species around the world, it is a native of South America. The countries of Peru, Bolivia, and Colombia provide the plant with soil rich minerals, lots of sunshine, rocky mountainous terrain, cool temperatures,

\footnotetext{
53 Jamaica Botanical Department. (1887). Bulletin of the Botanical Department, Jamaica. Government Printing establishment. In Jamaica, [in 1989] coca has been grown successfully at nearly sea-level at spring garden [now Nature's Way a nature park for camping, canoeing, fishing, river swimming and snorkeling.] The leaves yielding $0.76 \%$ of total cocaine- a very high percentage and remarkable considering the plants were only 6months old when the leaved were gathered. There has been no success at present in growing the plants at Cinchona at an elevation of $5000 \mathrm{ft}$. and possibly the night temperature is too low as it falls sometimes to 53 degrees Fahrenheit. At castleton-600 ft. and in the Parade Garden Kingston coca has been grown or some years but the Castleton leaves have not as high a percentage 0.65 as those from spring garden
} 
and the right altitude necessary for the plant to yield high levels of cocaine alkaloid. The climate in the majority of the island would be too hot for the coca plant, which seems to excel in cooler temperatures. With only 40 square feet of Jamaica above 5000 feet and almost half of the island over 1000 feet above sea level, commercial cultivation of the coca plant grown in Jamaica would potentially yield low levels of the cocaine alkaloid. Further, given the not so ideal climate cultivation of the plant would lead to costly monitoring and maintenance to ensure any kind of profitability as a drug. In addition, the crops would not be easily protected from local law enforcement given the limited areas on the island that are topographically ideal for successful cultivation of a plant that would yield high levels of cocaine alkaloid.

In relation to cocaine production, cannabis also undergoes relatively little processing, and is widely sold and consumed in its natural form [dried marijuana leaves.${ }^{54}$ Even as we look past the impracticality of cultivation, the complexity of the multiple stages of the cocaine process, the potential high value of the product at its final stage has not dissuaded the Jamaican smuggler from partaking in the profits to be earned. With established routes and infrastructures used in the drug trafficking of Cannabis (Williams L., 2004), cocaine proves to be ideal solely as an illicit transshipment product.

\footnotetext{
${ }^{54}$ DEA. (1993, September). Coca Cultivation and Cocaine Processing: An overview. Retrieved September 22, 2013, from Schaffer Library of Drug Policy: www.druglibrary.org/schaffer/govpubs/cocccp.htm Highly responsive to location and climate, coca leaves like cannabis are often processed close to the source. Its conversion to coca paste takes several days and is a relatively simple process of combining the leaves with water and sodium carbonate and then adding kerosene. By agitating this mixture cocaine alkaloids are separated from the solution, and is further processed to produce the coca paste. The final two stages of cocaine production are considered the most complicated, requiring specific equipment, skills, and care when handling the solution. In the final stages the process requires converting the coca paste to cocaine base which involves the used of sulfuric and hydrochloric acid, as well as using more expensive and dangerous chemicals to alter the cocaine base to cocaine hydrochloride (HCI)- cocaine powder
} 
Crack Cocaine: Given the high cost of cocaine and the increasing supply of cocaine, by the mid 1980's cocaine flooded the U.S market and forced a drastic fall in its price by up to $80 \%$ (DEA). In order to maintain the value of cocaine and, at the very least, restore profits a new cheaper form of the drug need to be marketed to a larger market share. Crack cocaine is this product. "It is an inexpensive, smokable form of cocaine that is easily accessible to lower income communities" (Webb, 1999, p. 141).

In the case of Jamaica, crack opened up a new demand market that it could profit from. In addition to merely transshipping cocaine, Jamaican drug dealers were converting cocaine to crack and distributing it (GlobalSecurity.org, 2011). Within the U.S, by the early 1990's the Jamaican Posse became known as one of the largest distributors of cocaine and crack on the east coast (Webb, 1999, p. 210). Converting cocaine to crack cocaine requires mixing cocaine power with baking soda and water, and then applying heat until solid "rocks" are formed. This simple and cheap process requires already processed cocaine, little equipment, and little skill. Most importantly, it is easy to transport and highly profitable. It is for these reasons that crack cocaine is considered a lower risk to process when compared to cocaine processing in Jamaica.

Approximately five crack houses and one safe house have been identified within the Tivoli Gardens garrison (see figure 18). These locations have been in existence since the 1980s under the leadership of Jim Brown, and later under Christopher 'Dudus' Coke. "From [these crack houses], Dudus generally [processed and] sold smaller quantities of crack cocaine to people in the Tivoli Gardens Community, and larger multi-ounce quantities, including in powder form, to residents of other communities. These crack housed generated approximately $\$ 100,000$ Jamaican dollars (approximately $\$ 4,300$ US 
dollars) per week in the early 1990s" (The Jamaica Observer, 2012a) ${ }^{55}$ Further, the safe house was used not only as a hide out spot for members of the Shower Posse Organization, but it was also used as a place to prepare drug mules for travel to the United States, as well as a place to store cocaine for distribution.

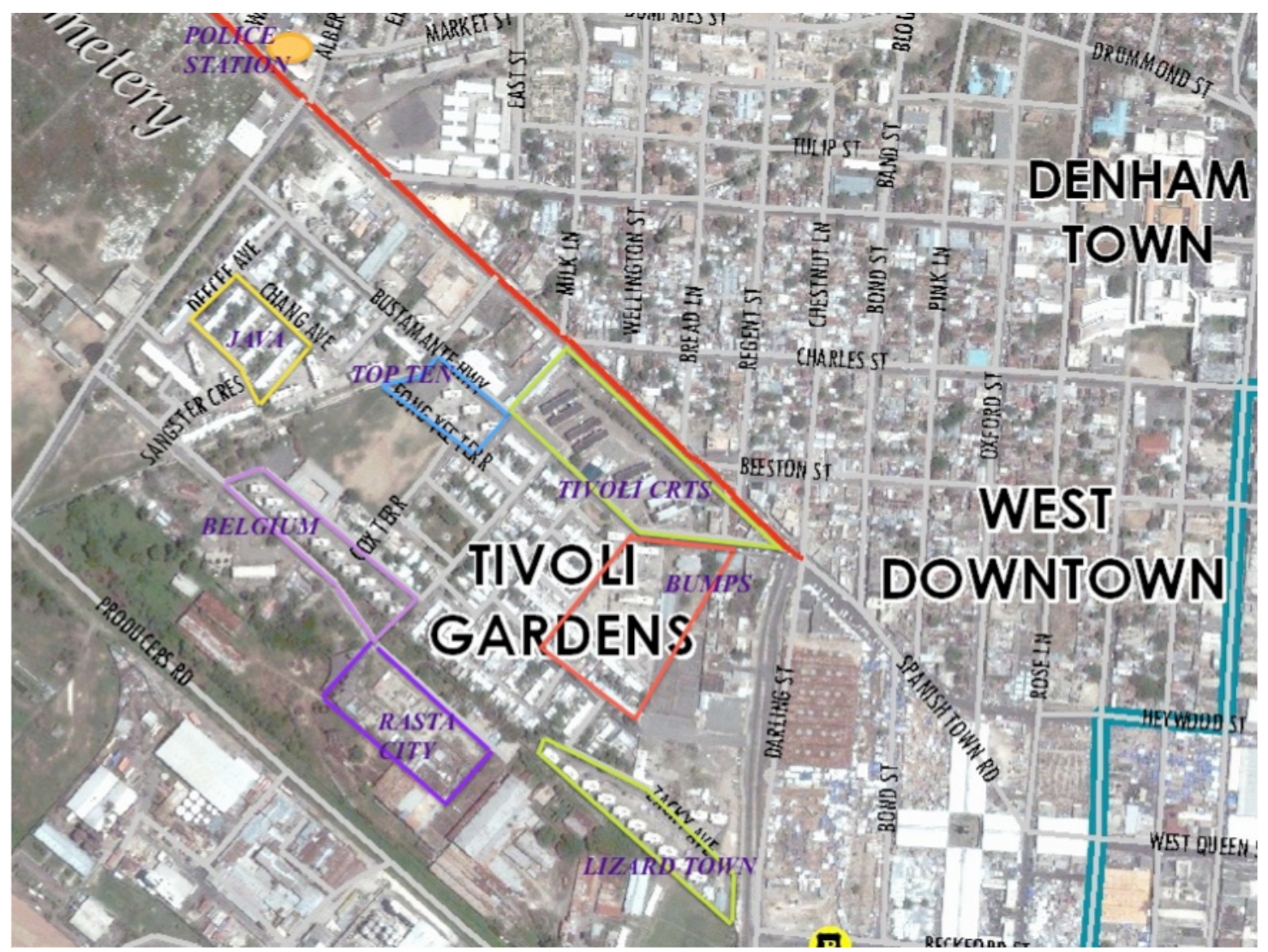

Figure 18. Tivoli Gardens Crack Houses

Note. Two of the crack houses were located in Java, a third was located close to the Top Ten area, a fourth was located in Little king Street near the Dunham Town Police Station, and the fifth was in the Lizard Town area. A safe house was located in Belgium.

\footnotetext{
${ }^{55}$ Statement came from cooperating witness $1(\mathrm{CW}-1)$ in during the prosecution of former Tivoli Gardens strongman Christopher 'Dudus' Coke in the United States May 2012
} 
Similar to the distribution system for cannabis, cocaine distribution in Jamaica typically begins in rural areas. However, where the cannabis distribution begins with its cultivators- farmers located in hard to reach areas- cocaine distribution in Jamaica begins with the fishermen who are paid to retrieve bundles of cocaine strategically dropped off at sea. Not produced locally, cocaine is transshipped from Panama and Colombia to Jamaica and then, it is later re-routed to the United States. "The domestic distribution moves from rural coastal communities to the cities where it is retailed locally and redistributed to rural population centers [primarily those areas with a vibrant tourism industry], some of which are the very points at which it entered the country" (Dreher \& Shapiro, 1994, p. 364). The head of criminal gangs within garrisons' controls the distribution of cannabis, cocaine, and crack-cocaine overseas. It is through their alliance with other criminal entities outside of Jamaica that overseas contacts are established and the large-scale exportation of drugs takes place.

Once cocaine reaches the retail level (usually the crack bases), however, the distribution system becomes a labyrinth of intermediaries as it moves, sometimes vertically and sometimes laterally, towards the consumer. Much of cocaine sold by base operators is sold to non-using individuals who are part of an elaborate distribution network of middle persons (crack house operators, pimps, hustlers, prostitutes, hotel workers, exotic dancers, 'runners' and taxi drivers) that eventually reaches the customer... On average, there are as many as $10-12$ intermediaries between the fisherman who retrieved the bundle of cocaine from the sea and the ultimate consumer. Each of these individuals takes a share of the 
profit, assumes a share of the risk, and is exposed to the possibility of becoming a user themselves. (Dreher \& Shapiro, 1994, p. 364-365)

Domestic Markets for Cannabis and Crack-Cocaine: While, cannabis and crack cocaine are the two most widely used substances in Jamaica, the degree to which each drug is cultural accepted within the society has significantly determined how each drug is manifested, how extensively they have spread, and their frequency of use. Jamaica has had a culture of cannabis use from as early as the 19th century. "There is a strong cultural tolerance for ganja and for most of the working class, and despite the fact that it is considered an illegal substance by the Jamaican government, it simply is not regarded as a 'drug"” (Dreher, 2002, p. 123; Dreher \& Shapiro, 1994). Supporting this point, one community leader (interview, July 30, 2012) indicated that he did not believe that Jamaica has a drug problem. Rather, he saw the smoking of marijuana as a cultural norm that is used to criminalized the lower classes within the garrisons: "if someone gets caught the emphasis is not so much on the smoking of the 'spliff' but on the fingerprinting of the individual and the creating of rejects". Within the society, the Rastafarian community considers cannabis a sacrament. When smoked, the user achieves higher levels of consciousness, allowing them to engage in intellectual thought and discourse. The drug also, is used for medical and therapeutic purposes among the wider society. When consumed in tonics and as a tea, cannabis is believed to improve one's health by providing individuals with vigor, appetite, intellect, and meditation. Crack cocaine on the other hand, has no cultural roots within the society, nor any perceived benefits to its use. Where cannabis users are viewed in a positive light, crack cocaine users are generally seen as: 
Undisciplined, lazy, and even unhygienic person[s]. In a society that values 'clear' skin, fleshiness, sexual vigor, self control and family loyalty, the 'mawga' (skinny), debauched, impotent crack user is seen as fundamentally 'bad,' violent, self-serving, and the antithesis of everything that is good and important in Jamaica (Dreher, 2002, p. 124-125).

Given the low opinions of the society towards crack addicts, these individuals are typically banished from their communities out of distrust and repulsion. The negative opinions regarding crack cocaine and its effect on individuals have in turn limited its acceptance and availability in local markets, "cocaine is okay to sell but not to use" (Chevannes, 2001, p. 36). In keeping with its cultural acceptance, cannabis, although illegal, can be purchased in small mom-and-pop shops and corner stores across the country (Broad \& Feinberg, 1995). Crack cocaine on the other hand, supplies a smallscale local demand and is often purchased and used in the few crack houses in existence.

In 2010, the Inter-American Drug Abuse Control Commission conducted a study on drug use among secondary school students between $13-17$ years of age. Consistent with the primary age group of individuals affiliated with gang activities (Moser \& Holland, 1997), the data reveal that in keeping with the drug use culture of Jamaica, cannabis is more readily accessible to the youths than other drugs such as cocaine and crack. Of the $38 \%$ of students who found easy to obtain Cannabis, $24 \%$ had tried it at least once in their lives. However, only $3 \%$ of students in the study admitted to trying cocaine at least once in their lives, and approximately $2 \%$ admitted to trying crackcocaine [see Table 4] (CICAD). Further reinforcing the domestic level of acceptance of 
Cannabis over cocaine and crack, roughly $19 \%$ of students had been offered cannabis at least once in their lives, compared to only $2 \%$ having been offered cocaine.

Further, an increased use of crack-cocaine is tied to the smoking of 'seasoned' spliffs. These are hand made marijuana cigarettes sprinkled with crack (Stone 1990). Dreher's 2002 study indicated that crack users in Jamaica found 'seasoned' spliffs to be a great way to counter the undesirable effects of smoking crack. The mixing of the two drugs allowed the cannabis to minimize the paranoia and weight loss encountered by the crack, by opening the appetite and allowing them to still carry out daily functions and awareness.

Table 4. Student Drug Use in Jamaica 2010

\begin{tabular}{|c|c|c|c|c|c|}
\hline \multicolumn{6}{|c|}{ Perception of Availability } \\
\hline & & Easy & Difficult & Impossible & Don't Know \\
\hline & Cocaine & 8.0 & 20.5 & 23.6 & 43.7 \\
\hline & Crack & - & - & - & - \\
\hline \multicolumn{6}{|c|}{ Access to Cannabis } \\
\hline & & Easy & Difficult & Impossible & Don't Know \\
\hline & & 38.36 & 15.27 & 12.8 & 33.58 \\
\hline \multicolumn{6}{|c|}{ Prevalence of Cannabis by Ease of Access } \\
\hline & & Easy & Difficult & Impossible & Don't Know \\
\hline & & 23.77 & 7.86 & 6.02 & 3.97 \\
\hline \multicolumn{6}{|c|}{ Prevalence of Illicit Drugs } \\
\hline \multicolumn{2}{|c|}{ Cannabis } & \multicolumn{2}{|c|}{ Cocaine } & \multicolumn{2}{|c|}{ Crack Cocaine } \\
\hline Lifetime & Past Year & Lifetime & Past Year & Lifetime & Past Year \\
\hline 21.56 & 12.04 & 3.12 & 2.02 & 1.63 & 0.00 \\
\hline \multicolumn{6}{|c|}{ Illicit Drugs offered to Students } \\
\hline \multicolumn{2}{|c|}{ Cannabis } & \multicolumn{2}{|c|}{ Cocaine } & \multicolumn{2}{|c|}{ Crack Cocaine } \\
\hline Past Month & Past Year & Past Month & Past Year & Past Month & Past Year \\
\hline 11.7 & 19.3 & 0.6 & 1.8 & - & - \\
\hline
\end{tabular}

Note. Chart compiled from data obtained in CICAD. Comparative Analysis of Student Drug Use in Caribbean Countries: A report on student drug use in 12 Caribbean 
Countries. 2010: Organization of American States. Sample size for Jamaica is 4,536 with a weighted population of 61,981 . Within this sample, $48.81 \%$ were male, and $51.19 \%$ were female. Of the 4,536 students interviewed, $39.74 \%$ were age 14 and below, $37.53 \%$ were between the ages of $15-16$, and $22.73 \%$ were age 17 and older.

Weapons. Jamaica's increasing crime rates are characterized by greater access to weapons among the urban poor during the mid-1960s through early 1970s, and by the use of more powerful weapons since the 1990s. Specifically, these weapons are wielded primarily by the criminal elements residing within the capital's garrisons. Jamaica's political culture and its power hungry political party system have long been identified as the instigators of violence within the country's poor urban communities. With limited access to guns before the mid-1960s, ${ }^{56}$ the weapons of choice were primarily knives and machetes. Some gangs had as many as two guns available. These weapons often were signed in and out when various members required use of them. It was during this timeframe that urban gangs like the Tivoli gang began to redefine their identity under a political banner. Their affiliation with the Jamaica Labour Party- one of the two, main political parties- allowed them access to small arms or "vote-getter," ${ }^{57}$ reinforcing the culture of political violence, rooted within urban areas referred to as garrison communities.

Towards the end of the 1950's through the mid-1960s, the majority of urban gangs in Kingston began to restructure themselves along political party lines- choosing to

\footnotetext{
${ }^{56}$ The first guns came in the late 1950 s and early 1960 s

57 Small, G. (1995). Ruthless. The global rise of the yardies. Warner. Vote getters, the term used at the time to refer to the guns given to gangs by the political parties.
} 
form associations and/or affiliate themselves with either of the two main political parties. The political identity of the gangs started to take shape before the occurrence of largescale political gang warfare, and before the extensive distribution of resources [jobs and low income housing] by both political parties. As Sives (2010) points out, The gangs located predominantly in the poorest and most deprived parts of the city were co-opted into the political battle by leading political figures. Further, the gangs lived and operated in areas, which had been political battlegrounds since the 1940s. This ensured that gangs already operated within a set of partisan frameworks, which had been constructed via material, and identity based political narratives over a period before their engagement (p. 62).

These early gangs provided the political party with their readiness to enforce the will of the political party using violence. By the mid to late 1960s with the creation of low income community housing, the political scope of the gangs expanded to include the guaranteeing of electoral support of community voter, and their willingness to preserve the electoral loyalty of communities by protecting residents from armed enemy insurgents- associated with the other political party. "In this sense, ostensibly criminal gangs like the Tivoli crew were transformed overnight into 'respectable' private political armies" (Small, 1995, p. 11).

Although the presence of guns can be traced to as far back as the 1950s and more specifically, to the 1959 election (Sives 2010), Small (1995) argues that some of the earliest 'major' acts of gun related violence, occurred in 1964 when the political parties, through their 'private political armies', fought for control of the Kingston \& St. Andrew Corporation Machinery. Comprised of the elected representatives of the urban residents 
of the corporate area, control would ensure that the majority party would have control over the policy-making goals of the council; thereby controlling the distribution of resources to the area. The level of political violence escalated leading up to the 1967 election, and continued throughout the 70s and 80s. Under the banner of campaign rhetoric, both parties denied accountability in the violence that was taking place primarily among garrison constituencies in West Kingston. They also denied playing any part in the arming of residents within these communities despite several police raids on the party headquarters and offices of both political parties. These raids led to the discovery of a number of weapons including knives and firearms, homemade bombs, ammunition, and evidence of firearm practice (Sives, 2010, p. 72).

The control that the political parties assumed to hold over these political enclaves soon began to slip away by the 1960s when Jamaica entered the cannabis trade. With the clampdown of the Mexican border, Jamaica's criminal elements took up the gauntlet of becoming the next major supplier of cannabis in order to satisfy the demands coming from the U.S. market (Sives, 2010; Headley, 1995). "The commodification and export of ganja brought large U.S. and Jamaican capitalists into the trade so that by the middle of the 1960s the ganja trade was a multi-million dollar business" (Sives, 2010, p. 61). The firearm has become the major weapon of choice used to protect this business and all legal and illegal businesses or products that spinoff from the supply of cannabis. The firearm has also remained the primary means by which garrisons conduct their political obligations to the political parties.

With Jamaica's large-scale entry into the drug trade, guns and the illegal drug trafficking have formed a symbiotic relationship. As state previously in this work, the 
drug trade offered criminal entities residing within the garrisons, access to a steady stream of resources that were central to the livelihood of the poor residing within these communities, and that would not have exist under normal circumstances. The number of urban gangs surged, and the garrisons became filled with a plethora of gangs made up of the socially and economically excluded. These gangs assumed a complex mix of political and drug supplier related identities. From early on, gangs recognized the importance of a political alliance. Despite an alternative access to resources via drugs, for the most part, they sought to preserve these ties. If the gangs did a good job mobilizing their communities and protecting its political identity, then not only would they benefit from resource such as jobs and housing the entire time their party was in power, but they would have greater change of minimizing the risks associated with the drug trade. If, their political party was not in power, then their affiliations with members of the opposition party would still allow for some protection when carrying out illegal activities. By the mid-1970s through the 1980s, Jamaica experienced unprecedented levels of violence from urban gangs. Rather than turning against the state, political violence was complimented by drug violence and gang violence, as criminal groups turned against each other to protect their local and international shares in illegal markets, and maintain their political loyalties and alliances. The country's reputation for violence, as well as its brand of "violence" has continually been bolstered by its high homicide rates over the years. In 2011, of the 2,452 violent crimes committed 54\% were identified as shootings, with the remaining $46 \%$ attributed to murders. Further, during that same year, $69.9 \%$ of all murders were gun related. ${ }^{58}$

\footnotetext{
${ }^{58}$ See the Jamaica Constabulary Force Annual Major Crime Statistics Review for January 01-December 31,
} 
Access to weapons: Jamaica does not manufacture is own firearms and ammunition. In order to meet its defense and security needs, as well as quell local demands for civil ownership, Jamaica relies on the importation of firearms and ammunition from several firearms and ammunition exporting countries from around the world. In keeping with world trends that reveal an increase in the volume of the firearms traded, and the number of suppliers over time, Jamaica since the 1990s has experienced an increase in its access to small arms and ammunition. Between 2007- 2011 the Caribbean region has receive $11 \%$ of world arms exports. More specifically, Jamaica consistently receives the majority of its firearms and ammunition from the top two major arms suppliers, the United States and the United Kingdom who assume 30\% and 24\% of the market share, respectively, for the distribution of arms trade ( Stockholm International Peace Research Institute, 2012). ${ }^{59}$

\section{The trend in transfers of major arms, 2002-11}

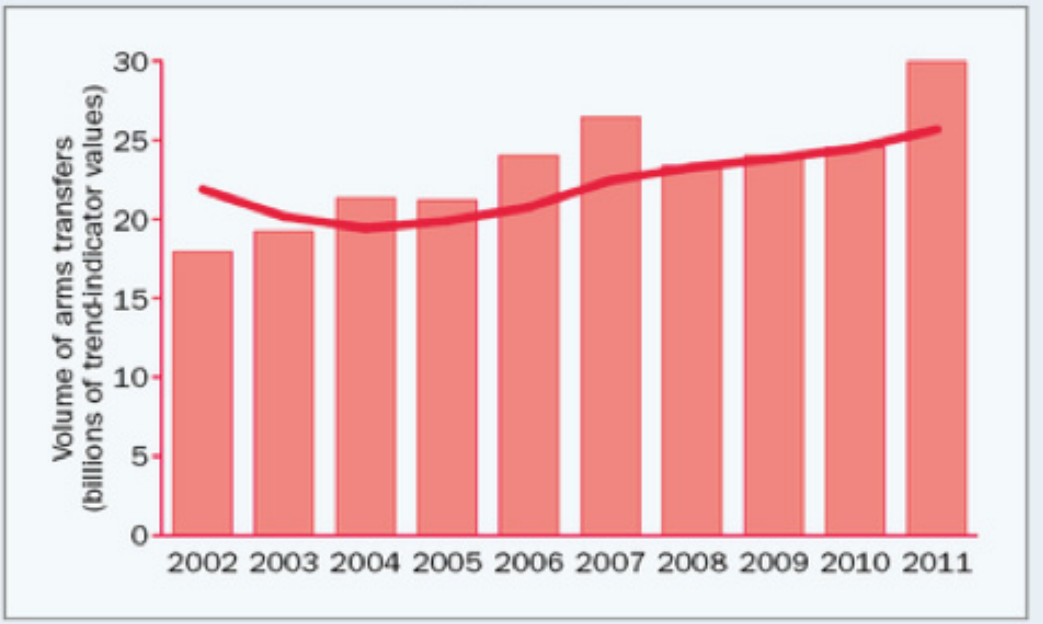

Figure 19. Trend in Transfer of Major Arms 2002-2011

2011 and comparisons for 2010 and 2009.

http://www.jcf.gov.jm/sites/default/files/major_crime_review_jan_01__december_31_2011_provisional.pdf

${ }^{59}$ Between 2007- 2011, the five largest suppliers of small arms have been the United States, Russia, Germany, France, and the United Kingdom 
Table 5 Firearms and Ammunition Imports to Jamaica by Country of Origin 2006-2011

\begin{tabular}{|c|c|c|c|c|c|c|c|c|c|c|c|c|}
\hline \multicolumn{13}{|c|}{ Firearms and Ammunition imports to Jamaica by Country of Origin 2006-2011 } \\
\hline & \multicolumn{2}{|c|}{2011} & \multicolumn{2}{|c|}{2010} & \multicolumn{2}{|c|}{2009} & \multicolumn{2}{|c|}{2008} & \multicolumn{2}{|c|}{2007} & \multicolumn{2}{|c|}{2006} \\
\hline Jamaica & $\$ 1,553,166$ & & $\$ 1,897,800$ & & $\$ 2,105,503$ & & $\$ 1,373,612$ & & $\$ 760,223$ & & $\$ 4,698,703$ & \\
\hline $\begin{array}{l}\text { United } \\
\text { States }\end{array}$ & $\begin{array}{r}\$ 1,317,9 \\
60\end{array}$ & $\begin{array}{c}84.86 \\
\%\end{array}$ & $\$ 1,156,481$ & $\begin{array}{c}60.94 \\
\%\end{array}$ & $\$ 1,654,792$ & $\begin{array}{c}78.59 \\
\%\end{array}$ & $\$ 1,061,621$ & $\begin{array}{c}77.29 \\
\%\end{array}$ & $\begin{array}{r}\$ 348,28 \\
4\end{array}$ & $\begin{array}{c}45.81 \\
\%\end{array}$ & $\$ 1,264,196$ & $\begin{array}{c}29.91 \\
\%\end{array}$ \\
\hline Canada & - & - & $\$ 24,619$ & $\begin{array}{c}1.30 \\
\%\end{array}$ & $\$ 11,247$ & $>1 \%$ & - & - & $\$ 9$ & $>1 \%$ & - & - \\
\hline $\begin{array}{l}\text { United } \\
\text { Kingdom }\end{array}$ & $\$ 74,490$ & $4.80 \%$ & $\$ 141,375$ & $\begin{array}{c}7.45 \\
\%\end{array}$ & $\$ 60,766$ & $2.89 \%$ & $\$ 103,720$ & $\begin{array}{c}7.55 \\
\%\end{array}$ & $\$ 22,634$ & $\begin{array}{c}2.98 \\
\%\end{array}$ & $\$ 76,048$ & $1.62 \%$ \\
\hline Italy & $\$ 149,774$ & $9.64 \%$ & $\$ 76,811$ & $\begin{array}{c}4.05 \\
\%\end{array}$ & $\$ 100,424$ & $4.77 \%$ & - & - & $\$ 61,610$ & $\begin{array}{c}8.10 \\
\%\end{array}$ & $\$ 74,485$ & $1.59 \%$ \\
\hline Spain & - & - & $\$ 71,263$ & $\begin{array}{c}3.76 \\
\%\end{array}$ & $\$ 67,256$ & $3.19 \%$ & - & - & $\$ 83,145$ & $\begin{array}{c}10.94 \\
\%\end{array}$ & $\$ 242$ & $>1 \%$ \\
\hline France & - & - & - & - & - & - & - & - & - & - & $\$ 6,465$ & $>1 \%$ \\
\hline Belgium & - & - & $\$ 22,931$ & $\begin{array}{c}1.26 \\
\%\end{array}$ & - & - & - & - & - & - & - & - \\
\hline Austria & - & - & - & - & $\$ 2,313$ & $>1 \%$ & - & - & - & - & $\$ 4,945$ & $>1 \%$ \\
\hline Poland & - & - & - & - & - & - & - & - & $\$ 17,243$ & $\begin{array}{c}2.28 \\
\%\end{array}$ & $\$ 3,249,804$ & $\begin{array}{c}69.16 \\
\%\end{array}$ \\
\hline Thailand & - & - & - & - & - & - & - & - & $\$ 777$ & $>1 \%$ & - & - \\
\hline Brazil & - & - & $\$ 403,330$ & $\begin{array}{c}21.25 \\
\% \\
\end{array}$ & $\$ 138,860$ & $6.60 \%$ & $\$ 208,271$ & $\begin{array}{c}15.16 \\
\%\end{array}$ & $\begin{array}{r}\$ 226,42 \\
1\end{array}$ & $\begin{array}{c}29.78 \\
\%\end{array}$ & - & - \\
\hline Panama & $\$ 10,942$ & $>1 \%$ & - & - & $\$ 1,211$ & $>1 \%$ & - & - & - & - & - & - \\
\hline Colombia & - & - & - & - & - & - & - & - & - & - & $\$ 22,518$ & $>1 \%$ \\
\hline
\end{tabular}


To a lesser extent, Jamaica also receives firearms and ammunitions from Italy and Brazil, and to an even lesser extent from Canada and Spain [see table 5].

\begin{tabular}{l|c}
\hline Exporter & $\begin{array}{l}\text { Global } \\
\text { share (\%) }\end{array}$ \\
\hline 1. USA & 30 \\
2. Russia & 24 \\
3. Germany & 9 \\
4. France & 8 \\
5. UK & 4 \\
6. China & 4 \\
7. Spain & 3 \\
8. Netherlands & 3 \\
9. Italy & 3 \\
10. Israel & 2
\end{tabular}

Figure 20. Main Exporters of Firearms \& Ammunitions 2010

Note. Taken from Stockholm International Peace Research Institute. (2012). SIPRI Yearbook 2012: International Arms Transfer. Oxford University Press.

Along with the legal importation of firearms and ammunitions, there is a vibrant black market for illegal weapons. With a high demand for weapons by criminal elements, within the garrisons, older model weapons often make their way to Jamaica from some of the very same suppliers who provide legal arms to the country. While the Caribbean accounts for only $11 \%$ of legal world arms transfers, Jamaican law enforcement officials' highlight that $80 \%$ of all illegal weapons found in the region can be traced back to the United States (Harlem World Magazine, 2009). 
Table 6. Firearms \& Weapons Recovered by Type in Jamaica 2007-2012

\begin{tabular}{|c|c|c|c|c|c|c|}
\hline \multicolumn{6}{|c|}{ Firearms and Weapons Recovered 2007-2012 } & \multirow[b]{2}{*}{2007} \\
\hline & 2012 & 2011 & 2010 & 2009 & 2008 & \\
\hline Pistol & 336 & 285 & 354 & 296 & 332 & 323 \\
\hline Revolver & 113 & 110 & 131 & 124 & 123 & 161 \\
\hline $\begin{array}{c}\text { Homemade } \\
\text { Weapon }\end{array}$ & 73 & 53 & 81 & 83 & 95 & 93 \\
\hline Rifle & 37 & 21 & 81 & 19 & 27 & 44 \\
\hline Shotgun & 14 & 16 & 26 & 19 & 20 & 19 \\
\hline $\begin{array}{c}\text { Semi- } \\
\text { Automatic } \\
\text { Machine } \\
\text { Gun }\end{array}$ & 11 & 9 & 20 & 19 & 16 & 13 \\
\hline TOTAL & 584 & 494 & 693 & 560 & 613 & 653 \\
\hline Ammunition & 5,692 & 4,974 & 19,865 & 5,112 & 6,947 & 7,714 \\
\hline
\end{tabular}

In the case of Jamaica, the majority of illegal weapons recovered have been traced back to Florida and the counties of Orange, Dade and Broward- all counties with large Jamaica populations (Harlem World Magazine, 2009). Another major supplier of illegal weapons to Jamaica is Haiti. With the disbandment of the Haitian army in 1995 after grassroots pressure from the United States ${ }^{60}$ the Jamaica-Haiti guns for drug trade has allowed for a large number of military and illegal firearms made their way to Jamaica in exchange for drugs (Davis N. , 2008). While this is occurring to the east of the island, drug trafficking to the south of the island with Honduras, and the Bahamas to the north also involve the

\footnotetext{
${ }^{60}$ Sprague, J. (2012, September 6). Reviving Haiti's Army would harm Democracy. Retrieved September 23, 2013, from Miami Herald: www.miamiherald.com/2012/09/06/2988432/reviving-haitis-army-wouldharm.html "The country's worst human-rights abusers were driven underground with the inauguration of Haiti's first democratically elected government in February 1991. Only seven months later, however, military forces in the country ousted the country's elected president, Jean-Bertrand Aristide. A new paramilitary organization, the FRAPH, launched a wave of terror. After years of grassroots pressure on the United States and the United Nations to act, Haiti's democracy was restored in 1994. The country's army (entwined with the paramilitaries) was disbanded and judicial processes began. Yet, U.S. diplomats pressured for the inclusion of some former Haitian military into important positions in the country's new police force. As Human Rights Watch pointed out in a report at the time, the United States used sectors of Haiti's revamped security forces against the country's left-leaning grassroots movement."
} 
trading of guns, as weapon trafficking has at times become a means of payment between criminal networks (Dialogo, 2013).

Since the 1970 's, there has been a declining but steady flow of Jamaican migrants to the U.S., Canada, and the United Kingdom. However, the migration that occurred in the 1980's was mainly in response to political violence and the dispersing of politically affiliated gangs fleeing the country after the 1980 elections. ${ }^{61}$ The early beginnings of the liberalization of trade, local markets and finance allowed for the growth of organized criminal networks and the development of drug trafficking in cannabis, cocaine, and crack. Large Jamaican communities in the U.S., Canada, and the United Kingdom provided a perfect breeding ground for the forging of transnational networks and distribution channels for drugs and firearms that crossed the borders of the developed world. $^{62}$

${ }^{61}$ Glennie, A., \& Chappell, L. (2010, June). Jamaica: From Diverse Beginning to Diaspora in the Devloped World. Migration Information Source: Fresh thought, authoritative data, gobal reach. Jamaica suffered a significant loss in its skilled labor force in the mid 1970's to early 1980's when it experienced brain drain because of negative levels of growth and high levels of unemployment. It is estimated that the country lost as much as $40 \%$ of its middle class during this period with approximately 666,986 migrants leaving the island between 1970 and 1980, of which 458,161 destined for the U.S.

${ }^{62}$ See. Sives, A. (2010). Elections, Violence and the Democratic Process in Jamaica 1944-2007. Kingston: Ian Randle Publishers, p. 133-137; Thomas-Hope, E. (2004). Migration Situation Analysis, Policy and Programme Needs for Jamaica. United Nations Population Fund. The Planning Office of Jamaica. There has been a steady increase in the number of female migrants from Jamaica. From the 1970's through 2006, the average percentage of Jamaican born females in the U.S is 53 per cent analysis, policy and program needs for Jamaica.; Glennie, A., \& Chappell, L. (2010, June). Jamaica: From Diverse Beginning to Diaspora in the Devloped World. Migration Information Source: Fresh thought, authoritative data, gobal reach. These high levels of migration result from "improved levels of female education and changing labor markets overseas." ; Hyland, J. (2002, January 11). Britain:Behind the roe over Jamaica "drug mules". Retrieved September 22, 2013, from World Socialist Web Site: www.wsws.org/en/articles/2002/01/jam$\mathrm{j} 11 . \mathrm{html}$. They work to the advantage of drug smugglers looking for alternative ways to smuggling drugs across borders. In 2004, women were reportedly being paid anywhere from US $\$ 2,880$ to US\$7,200 for each trip. The majority of women is lulled into carrying drugs because they are single parents, unemployed, and in need of start up costs once they migrated to far and distant lands, while others are coerced by threat to act as carriers; Hall, A. (2009, October 18). Trinidad Bound-Jamaican drug mules rush to the twin island republic. Retrieved September 23, 2013, from The Gleaner: jamaica- 
Driven in part by its suppliers, as well as by demands and access, the weapons in greatest demand in Jamaica tend to be pistols and revolvers. Recovering an average of 600 weapons a year over the last six years, pistols and revolvers account for roughly $90 \%$ of these recoveries. They also account for the type of firearm usually reported stolen on the island. The street value for ammunition and the variety of weapons often seized by the police, also indicate that within the criminal world, in addition to pistols and revolvers there is an abundance of illegal military style firearms readily available. Published reports, in the Jamaica Gleaner of the types of weapons often seized by law enforcement officers include, Ak-47s, Sniper rifles, M-16s, shot guns, Mac 11s, tec- 9s, telescopic lens, 45s, 3.75 magnums, ballistic vests, silencers, and of course the ammunitions that accompany them (Jamaica Observer, 2012a; Sinclair, 2005). Although semi automatic machine guns are generally recovered the least, the street value of the bullets used in this weapon tends to me the most expensive. This is because, "everybody has one of those (AK-47). That is why it carries the highest price. It sells like hot bread" (Reid, 2013). Not only are illegal weapons and ammunition broken into parts and smuggled into the island, but also they are stored within the homes of people residing within the garrisons.

Firearms were generally stored in the homes of the elderly residents, or residents who had legitimate jobs and therefore were less likely to be suspected or searched by the police. These people were not asked whether they wanted to store guns in their homes. Shotters would arrive at their homes and place the guns in either the ceilings or the back or front yards. Shotters would break long guns into parts, put

gleaner.com/gleaner/20091018/lead/lead1.html. Drug mules usually carry as much as two pounds of narcotics in 18 to 25 pellets. A pellet consists of a condom or latex glove stuffed with the drugs. 
the parts in rubber tubes and bury the tubes in the ground (Jamaica Observer, 2012a).

Although the street value for ammunition varies with weapon choice and by location, a recent expose, "\$280 for a Life" on the ability of the average person to access ammunition on the Jamaican street reveals that a box of fifty $9 \mathrm{~mm}$ bullets can be negotiated over starting at $\$ 155$ (JA $\$ 15,000$ ). Further, a single $9 \mathrm{~mm}$ bullet can be obtained for $\$ 2.89$ (JA \$ 280) or less. Other bullets like the M-16 carry a higher street value of $\$ 4.14$ each. Despite being illegal, persons interested in opting weapons simple need to find someone with connections to criminals willing to vouch for their credibility, as well as and negotiate on one's behalf with the supplier (Reid, 2013). 


\section{Summary}

Not only does Jamaica consistently face high levels of violence, but also the nature of the violence it experiences is understood best as one that has become increasingly transnational. First, the late 1970s through the 1980s revealed that the nature of violence shifted from primarily politically motivated violence to gang related violence. Second, the 1980s to the present indicates that, within the context of structural adjustment policies and liberal market forces, Jamaica's criminal groups have reconstructed the meaning and the use of violence to maximize profits and to exert influence.

Within localities such as garrison communities and within global markets, violence is utilized in multiple ways. In one instance, violence is separated from any local illegal product and is marketed as a separate brand. Here, it is designed to capture global markets interested in utilizing the services and expectations that come with the use of violence that is primarily 'Jamaican'. This includes but is not limited to global players hiring the brand at a specific stage of distribution or transshipment for a wide range of goods and services. Violence also is fused with localized illegal goods and services in order to maximize profits and to protect and expand market share. Violent illegal goods concern trans-local turf wars and the exerting of waves of influence from the local outward. As a transnational component, the violence constructed by criminal groups has in some ways framed/altered/shaped the policy responses of the state in regards the eradication of illegal markets. 


\section{CHAPTER 7}

\section{GLOBAL MARKETS, INFORMAL MARKETS AND THE GARRISON}

\section{Liberalization of Local Market}

Although, Jamaica is one of the earliest islands to reform its economy, signing its first Standby Agreement with the IMF in 1977, it was not until the early 1980s that the Country began the implementation of its IMF policies as the process of liberalizing trade began (King D. , 2000). By the early 1990's, liberalization of the financial sector was also underway. Inflexible exchange rates led to the creation of a flourishing foreign exchange black market, and Jamaica's privatization program further fueled a rapid reduction in state regulations. "During the first half of the 1980's state expenditure declined by 44 per cent between the budgets of 1981 and $1985 \ldots$ this reduction disproportionately affected the poor by decreasing expenditure on social provision, health and education" (Sives, 2010, p. 131). By the end of 1996, sixty-six privatization ventured had occurred (King D. , 2000, p. 20). This reduction in state resources directly affected the poor urban residents within garrison communities. Regardless of the fact that the Jamaican government had found creative ways to still maintain clientelistic relationships within the constraints of clientelism, the market had shifted out of the complete control of the state, allowing space for non-state criminal enterprises to flourish. Liberalization has provided criminal entities not only with a space in which to operate, but it has also fostered an increasing demand for illegal goods and activities. 
The liberalization of the market and the de-legitimization of state regulations have allowed criminal networks in Jamaica to take part in the drug industry at a lower comparative risk today than would have been possible in the early 70 's. Through the liberal democratic state, criminal networks are able to take advantage of the open borders and deregulated markets that the state encourages (Allen, 2006), forging illegal markets that run alongside legal channels of distribution. They are also able to benefit from the intensity and velocity of transactions and from the complex networks that make it hard to trace points of impact back to specific actors. The liberalization of the market has allowed these communities some autonomy and bargaining power. With the aim of reducing risks and maximizing profits, criminal groups within garrison communities establish transnational connections with state officials, ordinary people, and private enterprises in order to use state power and social capital to make their activities possible (Allen, 2006; Grupta, 1995; Lund, 2006). Further, criminal elements also reduce risk and maximize profits by creating economic incentives-within garrison localities- for groups and individuals to employ violence.

\section{De-legitimized roles of the Jamaican Government}

Economic weakening of the state. IMF policies and trade agreements with major exporters such as the United States (U.S.) have successfully encouraged developing countries such as Jamaica to open their markets to multinational corporations, while simultaneously removing quotas and decreasing tariffs on consumer imports. Regarding a decrease in the ability of the government to regulate and to influence global economic transactions that concern the Country, the Jamaican government has, more times that not, found itself in an altered shift in power where private transnational entities are able to 
increasingly influence policy. As is the case with all states in the global realm, the Jamaican state must play the role of the main actor in constructing a conducive environment for the development of its country. Among its primary roles is its responsibility to provide citizens with protection from both external and internal forces. It is the government's job to fuel economic growth, alleviate poverty and income inequality, advance human rights, as well as to strengthen state institutions through measures that guard against corruption and that ensure accountability and transparency (United Nations, 2004). The ability of the state to accomplish these multiple and, at times, conflicting goals is a perpetual balancing act that plays a toll on the perceptions of the state's legitimacy, especially when one factors in the constantly changing role of the state, a progressively evolving civil society, and the challenges a state and it's polity faces with increasing economic interconnectedness.

Gaining its independence in 1962, Jamaica introduced itself to the international realm as a Small Island Developing state (SIDS). The country made its debut as a newly established social and political order, geographically small, and with a relatively small population. Given its size the country has suffered from a lack of economies of scale; it is excessively dependent on international trade, and highly vulnerable to global development (SIDSnet). From the very beginning, the Jamaican state has had to structure its development around its limited economies of scale and the cultural norms that recognize Jamaica as a colonial and export oriented economy initially based on agricultural products such as sugar and banana. These limitations framed the limited infrastructure, the limited resource bases, and the highly dependent specialized industries that evolved in the industrial and manufacturing sector that developed in the 1940s. In 
creating the right environment for development, the government has interacted with multinational corporations that have often times reinforced the economic dependence of the Country and delegitimized the government's ability to fuel growth. A prime example is seen in the development of one of its primary products- bauxite.

Ten years after the discovery of large quantities of bauxite reserves found in Jamaican soil, the Country exported its first shipment for processing to the United States in 1952. Recognizing that the aluminum processed from bauxite was an invaluable commodity during the Second World War where aircrafts became an integral weapon of war, the Jamaican government set out to create an environment conducive to economic growth. The decision was to implement a series of policies that encouraged industrialization by invitation to foreign investors aimed at creating jobs that would absorb the excess labor from a declining agricultural sector. As the bauxite industry developed, four of the world's six largest Aluminum companies at the time were processing and mining in the country [Alcan, Kaiser, Alcoa, and Reynolds]. However, while economic growth did drastically increase overall, the interactions between these corporations only reinforced the Country's economic dependence. The capital-intensive nature of the industry did create some jobs, but it did not generate as significant a growth in the job market as expected. ${ }^{63}$ In fact, the creation of plants across the country significantly fueled expectations for jobs and helped to fuel rural to urban migration in search of work. In addition, these types of investment policies did not allow the Jamaican government to secure a real share in the total profits earned in the industry. The

${ }^{63}$ See Jamaica's Bauxite \& Alumina Industry, http://www.bunting.org.jm/sites/default/files/JBI_An\%200verview_of_Jamaica's_Bauxite_Industry.pdf Just over one-third of the over 13-14 million tons of bauxite mined in Jamaica each year is shipped unprocessed to the U.S.A. The rest is processed in four alumina refineries [on the island]. 
interactions between the Jamaican government and these multinational corporations involved constant negotiations over royalties fees, income tax payments, bauxite levy on exports, lease arrangements for local plants, and government ownership in local capital (Davis, 2012a; Davis, 2012b; Barclay \& Girvan, 2008).

As Lacey (1977) pointed out, the economic history of Jamaican has always been about the story of "too many people chasing too few jobs" (p. 7). Rapid industrialization in the country during the mid to late 40's followed by complications in its major industries such as bauxite led to poor wages, poor working conditions, rising unemployment, and social and political injustices among a wide cross section of its population. In addition, a large increase of rural to urban migration led to an overflow of urban communities filled with the unemployed, and the minimally educated. Although there were changes in taxes and ownership in the 1970s that benefited the Jamaican government, its interactions with other multinational corporations within other industries such as tourism tell a similar story (Stupart \& Shipley, 2012).

Political weakening of the state. The process of nationalism that occurred in the country during 1970's has also challenged the government's legitimacy. The expanding of state capacity to incorporate the needs of the country as a whole coincided with the government signing its first International Monetary Fund (IMF) agreement in 1977, in anticipation of expanding international trade.

From early on, the Jamaican state faces the pressure of alleviating the high level of dependence from specific portions of its population. Approximately ten years after its independence and in the midst of attempts to catch up to the rest of the word regarding development, the newly independent government began the process of nation building as 
an organizing and legitimizing tenet to supplement the consolidation of the state. However, this process also highlighted the limitations of the state's capacity. The country's motto "Out of Many; One People" serves as a symbol pronouncing sameness of experience and sameness of struggle. Nationalism helped to provide a common distinction of who Jamaicans are, what their common origin is, and what makes them distinct from others outside of the country rather than within. This was part of a statedriven and top down notion of nationalism. It also was viewed as a necessary tool since the middle class that led the movement for national independence was still primarily isolated from the urban masses. This has been evident in the expansion of the three ideologies of Africanism, Communism, and Rastafarianism that challenge the role of the middle class in government (Stupart \& Shipley, 2012, p. 27).

The ongoing process of nationalism taking place within the country in the 1970's affected state capacity in two ways. It simultaneously allowed the new leaders to expand their support base to the population as a whole, and it forced the government to remove central focus from the socio--economic needs of the poor [their larger support base] to the society as a whole. Ultimately, the drive for nationalism put pressure on the country's culture of clientelism that had developed between the lower classes residing within garrison communities, and political parties, via the state. 


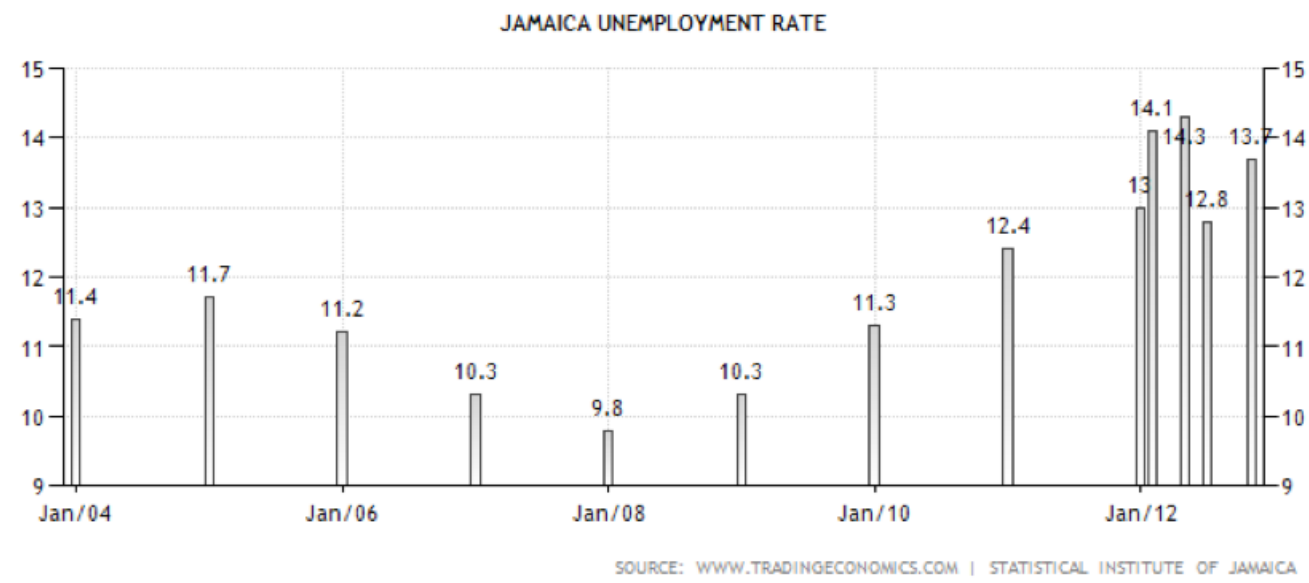

Figure 21. Jamaica's Unemployment Rate: January 2004-March 2013

Note. "Historically from 1991-2012, Jamaica Unemployment rate averaged 13.78 percent reaching an all time high of 16.50 percent in December 1997, and a record low of 9.80 percent in December 2007." Tradingeconomics.com. (n.d.). Jamaica Unemployment Rate. Retrieved September 23, 2013, from Trading Economics:

www.tradingeconomics.com/jamaica/unemployment-rate

Today, Jamaica continues to struggle with high levels of unemployment and large pockets of urban and rural poverty, with a third of the population living as squatters, despite the fact that the country has made tremendous progress in alleviating poverty across the board (Sullivan, 2010). On May 21, 2010, the Jamaica Observer reported that the rate of unemployment in the country has risen to an eight year high. Other reports state, "that the continuing decline in [the country's] gross domestic product (GDP) had taken place within the context of a 4.1 per cent increase in inflation and an unemployment rate of 14.2 percent at the end of January 2012” (Roache, 2010). 
Indicating that the Jamaican economy has been further affected by the global financial crisis and America's 'great recession' (Wessel, 2010).

Jamaica also carries a large burden of debt. It currently has the fourth highest debt burden per capita, and its debt-to-GDP ratio is greater than 120 per cent. From as early as 1963 Jamaica has displayed a negative balance on its current account, primarily because of fluctuations in commodity exports, import prices, devastating natural disasters, and global recessions (Sullivan, 2010). Vulnerability to external shocks and its large debt burden has resulted in a growing debt and a long history of loan financing through IMF agreements. This economic context has significantly shaped the nature of development and more specifically, community-based development in urban areas of Jamaica.

\section{Community-Based Development, Clientelism, and Liberalized markets}

Jamaica's limited economies of scale and its history of political party formation, have proven to be especially challenging to the process of bargaining between communities and local government, especially as it related to the distribution of resources and the pursuit of development within garrison communities. Levy (2012), points out that community development has taken place in three main stages, marked by initial success and followed by clear setbacks. The first stage begins with state assisted communities organizing during the 1930s and ended with community development programs framed by centralized government directed policy-making in the 1960s. During the second stage from the 1970 s to the 1980 s, party politics begin to drive the process of community development, alongside a push for public/private partnerships through neoliberal restructuring. The final phase, from the 1990s through 2000s reveals that despite having fully implemented structural adjustment policies in the 1990s, political parties still 
managed to find loopholes with neoliberal policies in order to maintain partisan infused development projects.

When taken together, these stages map the relationships that exist between the state and local communities as Jamaica transitioned from an isolated economy to a neoliberal democracy. At various points in history, the interaction between the state and local communities have fostered, modified, and maintained community-based development characterized by clientelistic ties.

Community Organization 1930s-1960s. Starting with a bottom-up approach to community development in 1937, the Jamaica Welfare Limited was established twentyfive years before Jamaica's independence. Norman Manley established the Jamaica Welfare Limited before forming the People's National Party (PNP) in 1938 and before the labor rebellion. The creation of Jamaica Welfare Limited was in response to the problem of overpopulation in urban areas following a reactionary wave of migration from rural to urban areas by banana workers in search of jobs after a plant-based disease negatively affected the industry (Jamaica Observer, 2012b). Motivated by the economic context, the organization sought to fuel community upliftment and local leadership, as well as to guide communities in the organizing of community councils geared towards self-improvement and self-help. By 1949, the organization was renamed the Jamaica Social Welfare Commission and became a statutory body, financed by the state (Crichlow, 2005, p. 76). The Jamaica Social Welfare Commission maintained Manley vision of allowing the masses access to state power. As a result, the commission was a nonpartisan, non-governmental body that was coordinated at the national level, and was comprised of several community and district councils. 
Yet, overpopulation and the rapid growth of urban slums in West Kingston continued to be a common occurrence through the 50s and 60s. Similar to other developing countries, Jamaica experienced a progressive housing market. A term used by Ferguson \& Navarrete (2003) to identify the acquisition of housing and the growth of communities based on squatting and on the purchasing of land or house in an informal sub-division. One such example was the community of Back-O-Wall in the 1950s; with over 50,000 residents, Back-O-Wall had three communal standpipes and two public bathrooms. It was regarded as one of the largest slums in the English speaking Caribbean at that time (Jamaica Observer, 2004).

Shortly after Independence in the 1960s and under the leadership of the Jamaica labor Party (JLP), Jamaica Welfare Limited was renamed the Social Development Commission (SDC), and underwent several changes. Under the JLP, the Commission's focus moved away from allowing the masses access to state power, to a focus on labor. Grassroots representatives were removed from the national body and there was a shift from any direct means of non-governmental control towards a state controlled organization. The commission was placed under the Ministry of Development and Social Welfare, and all policy decisions and development perspectives came directly from that office. What started as a bottom-up process was now being approached from a highly centralized top down perspective. During its transition, several community projects and programs suffered, and several grassroots agencies and community councils dissolved.

Further, the implementation of any community project and program, now had to model the directions specified in the Manual of Community Development. The Manual was a "detailed project document that elaborated the new approach, focused on building 
community centers, and strengthened the role of the resident village officer, who was to ensure the implementation of government plans" (Chrichlow, 2005, p. 77). By standardizing community development, the government created a plan of action that provided a generic approach to development devoid of community differences, experiences, and needs. All programs were identical across communities; what development projects to consider, how to communicate and interact with community members, how to identify leaders, and what skills training were beneficial for communities as a whole (Levy, 2012).

The prototype for this form of community-based development is Tivoli Gardens, created in West Kingston in 1965 and identified as the first formally established garrison in Jamaica. Tivoli Gardens was created out of the ashes of Back-O-Wall. Residents of Back-O-Wall were relocated to another community called Trench Town, the existing housing was demolished, and the remnants bulldozed and removed. In its wake government housing, a community center, sports fields, a library, and a maternity hospital, were constructed, and the new community was called Tivoli. According to the current Member of Parliament for West Kingston, Desmond McKenzie, “[Tivoli’s] centerpiece was the community center, built in the 1980s, the largest in Jamaica and housing a training center for a range of skills, a sports field, a library, and other facilities" (Jamaica Observer, 2004).

Tivoli Gardens was constructed in the same location of Back-O-Wall, one of several urban slums informally tied to the PNP before independence. Under the JLP administration, Tivoli was created, and the Back-O-Wall PNP aligned residents were relocated to other areas. Access to housing and the new community was determined by 
the Ministry, and was based primarily on political affiliation. Another way in which community-based development was tied to politics was through the branch system.

In a 2004 interview (Jamaica Observer, 2004), McKenzie highlights how the branch system was an integral part of JLP directed community-based development. In explaining his political journey, McKenzie revealed that it was common for community members to work their way into the political party by moving from simple community based jobs with no political ties, to duties and responsibilities that were directly related to the political machinery. His ascent began with being an outer guard [bodyguards stationed outside the location of political meetings to protect the political meetings from disturbances], to a party chaplain, to becoming the president of a group party branch, to becoming a member of the constituency executive, etc. The branching system described by McKenzie, in many ways falls in line with scholars such as Gunst (2003), Small (1995) and Gray (2004) who document a pattern of the politicization of community gangs between 1962-1967, and the transition of gang leaders into the more formalized role of community leaders during the 1967 general election. Political parties were able to foster ties, and establish relationships with a wide variety of community residents. More importantly, Figueroa and Sives (2002) refer to 'communal clientelism', a system which highlights a the exchanging of material favors in exchange for votes not just between specific individuals and the politician, but between political parties and all segments of the community.

Falling under the auspices of the government, the commission took on a partisan and clientelistic bent. The ministry's centralized approach made it the only entity with the authority to distribute large-scale resources to communities. Further, as a political post 
the determiner of funds would always be someone from whatever political party was in power. The ministry determined what the communities needed, how and in what form it would be disbursed, and finally, selected community members it deemed worthy of becoming potential leaders and mediators between the community and the state; thereby making the distribution of community resources extremely subjective.

1970s to 1980s: Party politics, social reforms, and neoliberal reforms. By the 1972, Jamaica experienced its third general elections and the People National Party (PNP) came to power for the first time. Within the context of a world oil crisis and a domestic environment in which unemployment and violent crimes where on a rise, the PNP operated through, "a phase of classical reformism, in which the national government strengthened its bureaucratic structures, even as it endeavored to create the perception of incorporating the marginalize in its corridors" (Crichlow, 2005, p.113). Reforms and development programs allowed the state to reclaim ownership of valuable resources and companies tied to public works, public infrastructure and public capital. ${ }^{64}$ The provision of low-income housing and the employment it would generate also played a central role in the policies of the government. So much so, that $70 \%$ of all construction that took place during the 1970s was attributed to government housing (Smith, 1996).

\footnotetext{
${ }^{64}$ Meditz, S. W., \& Hanratty, D. M. (1989). Role Of Government. In S. W. Meditz, \& D. M. Hanratty, Islands of the Commonwealth Caribbean; A regional study. Washington, D.C: Federal Research Division Library of Congress. Between 1972 and 1976, the Manley government carried out a small agrarian reform program, Project Land Lease, that sought to alleviate high unemployment by introducing job creation schemes and redistributing concentrated land holdings. The reform process included the creation of agricultural cooperatives, including the formation of Sugar Workers Cooperative Council, an important actor in the country's political economy. Seeking to reduce dependency on foreign investment, the government also nationalized with compensation all of the foreign-owned utility companies (electricity, telephone, and public transportation companies). The government also purchased sugar factories and the foreign-owned Barclays Bank.
} 
Similar to the JLP, the provision of housing and employment was tied to political affiliation. The PNP, on a larger scale, funneled government resources towards providing housing, employment and community development in several areas surrounding Tivoli. The proximity of distinctly partisan communities such as Arnett Gardens, led to a spike in violence during this period. However, between 1972 and 1980 the number of persons and communities loyally voting for the PNP also increased.

Furthermore, the PNP government's platform "Better Must Come," heralded in a wave of civil society and community members' interested in breaking down the centralized nature of the decision-making, and at regaining direct involvement in community-based development; as a result the number of community councils quadrupled in the 1970s. Recognizing the importance of political participation and the need for "a body at the community level with which policymakers can formally communicate and through which the people can seek to directly influence national affairs" (Levy, 2012), the government at first considered providing community councils with legal status:

Legalisation ran into two roadblocks, however. The first was the fear -- partly justified -- felt by parish councilors across party lines that their role would be undercut and even eliminated. (In fact, before any final decision could be taken, the People's National Party (PNP) was voted out of office.) The second obstacle generated by the Jamaica Labour Party (JLP) was the accusation that community councils were a communist device to "enslave people (Levy, 2012). 
By blocking the legalization of community councils, political parties ensured two things. First, the parish councilors from the PNP were able to ensure that these community organizations while under the auspices of the expanding state bureaucracy remained firmly controlled by the party machinery. Parish councils remained the only government agency responsible for the management and development of parishes, which are divided further into several districts and constituencies. Second, JLP politicians (returning to power after the 1980s elections) where able to preserve any partisan ties that that they had previously forged within garrison communities through their community leadership programs under centralization.

During the mid 70s-80s, Jamaica continued to suffer from a debt crisis. The economy continued to deteriorate; unemployment and violence were at an all time high. In addition, the PNP's social democratic government was under pressure from foreign aid agencies such as the International Monetary Fund (IMF) and the World Bank to carry out neoliberal reforms under the guidelines of the Washington Consensus in an attempt to recover form economic and financial crises. Partly in response to IMF loans and structural adjustments, and given the heavy expense of financing the housing industry, the government encouraged the presence of the private sector in the housing industry by established the National Housing Trust (NHT) in 1976. This statutory corporation was mandated to provide low-cost financing to low-income contributors in the aim of purchase a home or to improve upon an existing one.

[The] activity of the private sector was very low between 1971 and 1975, particularly because attractive finance was not available. But with the expansion of the Kingston Metropolitan Area (KMA), and when the NHT came on-stream, 
the private sector was encouraged to provide units within the Trust's price range to be sold to its contributors (Smith, 1996)

The 1980s also saw another general election in which the JLP assumed power. Under their leadership, community-based development organizations were restructured again, although "the new administration remained as distrustful of market-oriented economic solutions as its predecessor. The difference was that governmental intervention in economic matters would be directed towards a return to the encouragement of foreign investment, or 'dependent capitalism'; that is, pragmatically guided under state-directed development" (King, 2000, p. 13). In keeping with the funding requirements from the IMF and the World Bank, the government took on structural reform programs aimed at increasing the role of the market and the growth of the private sector. The manufacturing sector moved away from import substitution back to a focus on exporting, and the already established financial system expanded.

The government's housing policies also suffered a similar faith. National policy shifted from "provider-based" to "support-based" housing (Smith, 1996) while the government was focusing primarily on settlement upgrading, starter home, and build on own land programs. Within these guidelines, the NHT "concentrated exclusively on providing and servicing mortgages" (Smith, 1996, p 25). According to Levy (2012), this affected community-based development programs as parish councils were stripped of major functions and community development was outsourced to non-governmental agencies. In 1979, community-based organizations fell under the structured and bureaucratic wing of the Community Enterprise Organization (CEO), a project development company that helped to realize the government's idea for large-scale 
development in communities. By vetting, approving, overseeing, and providing loans for project financing, the $\mathrm{CEO}$ was able to control community-based development. Under the JLP, the CEO was dismantled and major functions of the parish council such as public cleansing and public health were redistributed to central government agencies and ministries; paving the way for non-governmental involvement in development.

\section{0s through 2000s: Structural adjustment, privatization, and the}

community leader: Where the 1980s saw economic reform as limited and still primarily driven by state-directed development, the 1990s witnessed an acceleration of economic reform policies, specifically those related to trade and investments. The early 1990s reveals a reduction in import tariffs, as well as the elimination of import licensing for a wide range of products. In addition, quantity based restrictions on imports and exports were lifted, and the simultaneous liberalization of the domestic capital market saw a removal of restrictions on the holding of foreign exchange accounts. Private individuals could now possess a foreign exchange account and could openly purchase foreign exchange from 'authorized' dealers other than the central bank. Introductions of a floating exchange rate, the stabilizing of the local currency, and the implementation of policies to reduce inflation, all helped to influence an increase in foreign investments among private citizens, and to attract foreign investments into the country from abroad.

However, King (2000) highlights the downside of constant and fast paced restructuring; "the economy suffered from the shocks of adjustment [and] the consequences of this and the structural adjustment, compelled by trade reform, produced a steadily declining economy in the 1990s" (p. 14). Where significance changes were taking place in the capital and trade markets, the labor market experienced the least 
amount of restructuring. "Apart from the effects of income tax changes on the labor market by 1998, the labor market remained substantially unreformed" (King 2000, p 24). In 1996, employment was recorded at an all time high of 16.4\% (Statistical Institute of Jamaica, STATIN), and the majority of citizens identified as unemployed, unemployable, and uneducated resided within garrison communities.

Structural adjustment policies significantly affected community-based development, by reducing both the size and the role of government, and individuals residing within garrison communities quickly felt this deficit in their ability to access resources. From the $60 \mathrm{~s}$ through the 80 s, clientelistic practices saw the unmeasured and openly accepted flow of resources to community-based development projects in exchange for political support and loyalty. Inner city communities such as Denham Town, Hannah Town, Salt Lane, and Tivoli Gardens, received training centers and schools under JLP leadership. Later, communities such as Arnett Gardens saw government resources flow their way when the PNP assumed leadership. During Christmas time, small time jobs were preferentially doled out to specific communities, and politicians eked out free shoes and clothing to community residents, and funded community shows and events. However, with the creation of the NHT at the end of the 1970s, and a full transition towards neoliberal markets from 1977 through 2000s, government's hold on the distribution of resources became limited.

The creation of the NHT sought to restructure the distribution of low-income housing from a process that was tied primarily to a person's political affiliation and the use of patronage by politicians, towards a priority index entitlement system (Jamaica Information Service, 2010). In order to benefit from low interest loans for purchasing a 
house, land, or to carry out home improvements, all gainfully employed citizens are required to contribute $2 \%$ of their income to the $\mathrm{NHT}^{65}$ Applicants are selected according to a priority index entitlement system based on the proximity of the future housing to current residence, and place of employment, as well as the number of years the applicant has paid NHT taxes, and the their yearly income. While this system succeeded in raising substantial sums of money for housing through the NHT, and allowed the government to offset some of the cost of housing to private sector, it did not solve the problem of housing and resources to inner city communities. The unemployed residing within garrisons did not qualify for housing loans, nor did they have the means of paying back these loans.

To fill this void, garrison communities have turned to prominent community leaders and criminal groups to fill the void left by government's 'absent presence'. Modeling most of the clientelistic practices in place up until the 1980s, community leaders and criminal groups have assumed the responsibility of bringing communitybased development to communities. Characterized by homogenous voting in favor of one political party or another, community leaders are able to bargain voting power in exchange for a share in the limited resources that political leaders are able to offer under neoliberal policies. Securing contracted menial government jobs to clean drain and gullies, to pave roads, and to work on construction projects, these generally are all secured through political bargaining. However, most community-based development is

\footnotetext{
${ }^{65}$ dogoodjamaica.org. (2011). Organizations: national housing trust. Retrieved September 30, 2013, from DOGOODjamaica: www.dogoofjamaica.org/organizations/national_housing_trust
} 
realistically a combination of political bargaining and resources earned from criminal activity.

In the wake of neoliberal policies moving the government away from directly financing community-based development, the Jamaican government in 2007 replaced the Social Development Commission (SDC) with the Constituency Development Fund (CDF). The CDF is a decentralized funding scheme implemented by the government of several countries in the developing world including India, Kenya, Pakistan and the Philippines. This represents a transition towards what Peck and Tickell (2002) refer to as the second neoliberal transformation that began in the early 1990s within the United States and Britain, and that continued in the developing world later:

When the shallow neoliberalism of Thatcher and Reagan encountered their institutional and political limits as evidence of the perverse economic consequences and pronounced social externalities of narrowly market centric forms of neoliberalism became increasingly difficult to contest. However, the outcome was not implosion, but reconstruction, as the neoliberal project itself gradually metamorphosed into more socially interventionist and ameliorative forms. This may be portrayed as 'roll-out' neoliberalism, underlying the sense in which new forms of institution-building and governmental intervention have been licensed within the broadly defined neoliberal project (Peck \& Tickell, 2002, pp. 388-389). 
By furnishing Members of Parliament with direct access to resources for community development, this scheme aims at counteracting market based neoliberal policies characterized by tight regulations limiting social housing, and the heavy reliance on the private sector to supply community welfare. Under the CDF in Jamaica, each Member of Parliament is provided with JM\$20 million (US\$200,000) dollar a year to carry out discretionary expenditure in their constituencies (Henry, M. 2010). With the CDF still maintaining a "neoliberal logic of infrastructural supply" (Aguirre Jr, Eick, \& Reese, 2006), the disbursement of funds and decision-making regarding how the funds will be used, generally revolve around the repairing of roads, rehabilitating housing, and/or the repair and construction of community schools and community centers.

There is generally a strong focus on technocratic decision-making. Where the disbursement of community-based funds by Members of Parliament involve the establishment and funding of committees comprised of development experts set up for the specific purpose of a potential project, and where these projects are managed at every stage by experts on the ground. Ironically, neoliberal policies have also reinforced clientelistic relationships by first, outsourcing the financing and construction of housing to the private sector, and second, by leaving the government and non-profit nongovernmental groups with the sole responsibility of negotiating with the informal market regarding social housing. Collaborating on ways to solve the problem of housing among the unemployed and those living on less than minimum wage, inevitable leads to the forging of networks with prominent community leaders [regardless of whether they head criminal groups or not] regarding self-help housing and the upgrading of squatter areas. 
While neoliberal policies have limited the flow of resources from the government, they have enabled the expansion of the private sector, with that, wider access, and means of taking part in legal and illegal private markets. The community leader within garrison communities is able to bargain on the behalf of the community, because he/she is able to assume the responsibility of protector. That means that they must not only be able to secure and distribute resources through political alliances, but they must also be able to mobilize their own resources and wield them. As a result, political bargaining also leads to financial collaboration in providing communities with infrastructure and resources. Further, as players in a global market, community leader tied to criminal activities, are now able to provide community-based development on a more consistent and steady basis, than a political leader who is only able to care for community when he/she is in a position of power.

As a source of income, criminal activities are protected from outsiders by restricting access within the community, and by excluding outsiders. Community leaders reinforce community loyalties by modifying patronage relationships to include community- don [See chart in Chapter 6]. They are identified as community saviors who ensure that illegal access to utilities are protected, that access to housing is available and determined based on allegiance, and because they provide for the community when the politician cannot. Regardless of the fact that the Jamaican government had found creative ways to still maintain clientelistic relationships within the constraints of clientelism, the market had shifted out of the complete control of the state, allowing space for non-state criminal enterprises to flourish. 


\section{Fostering a Culture of Tolerance for Smuggling}

The presence of criminal groups within the garrisons has played a key role in fostering a thriving economic livelihood in illegal products and services among the poor and the underprivileged. Further, according to Gillespie and McBride (1996) the presence of criminal groups help to, "explain the tolerance of smuggling within the broader social context of emerging markets" (p. 42). This rationale for how the use of smuggling influences local communities, is similar to chapter five's discussion of how the use of violence has helped to construct structural violence as a normal part of the everyday life of Jamaican citizens, and specifically, as a normal part of the lives of people who reside within garrison communities. In the case of smuggling and in an involvement in illegal activities, criminal groups within the garrison have managed to successfully organize and control illegal markets that generate profits that they then allow to trickle down into the communities in which they reside. The ability of these criminal groups to generate wealth within communities in desperate need of social and economic relief means that these criminal entities are actively shaping the community's tolerance for illegal activities and their varying levels of involvement. Tolerance can range from, a resident receiving money for passively accepting that their back yard in one of many locations in which illegal weapon parts have been hidden (Jamaica Observer, 2012a) or, a higgler/informal commercial importer accepting payment for allowing a few boxes of their exports to be packed alongside illegal goods. This does not mean that everyone who resides within a garrison is a criminal, it just means that law abiding citizens within these areas, often times must carry out their daily lives within legal gray areas in order to survive. 
A long-standing history of clientelistic practices and relations has helped to foster a tolerance for smuggling and criminal activity. The prominent role given to criminal groups within garrisons as both political mediators between its residents and the state, and as community benefactors has provided these groups with the influence to construct and reinforce community norms. In most cases, the ability to source jobs and to generate income within the community automatically determines who will be considered a community leader; access to weapons and individuals willing to protect this position and access to legal and illegal resources becomes vital. Community leaders play a critical role in helping rural to urban migrants, the unemployed, and the minimally educated, to obtain work. By obtaining public works contracts for the Jamaican government, through legally constructed companies, community leaders are able to dole out short term contractual employment to community residents.

These jobs include, but are not limited to waste disposal, the cleaning of drains and gullies, the repair of roads, and the beautification of public spaces. In 2010, Contractor General Greg Christie revealed, "just under 12,000 government contracts valued at [US\$880 million in 2009 was] awarded to contractors, most of whom were private entities and whose certified beneficial owners were either unknown or not readily identifiable" (Jamaica Observer, 2010b). Further, in the same year Incomparable Enterprise Ltd, one of several companies associated with Christopher 'Dudus' Coke, received from the National Contract Commission US\$710,000 of the US\$880 million awarded in government contracts (Beckford, 2010). 
Community leaders involved in criminal activities and markets are also able to generate more long-term and consistent income to individuals within these communities through illegal jobs and legitimate community development and renewal projects. As Leslie (2010) points out, "The quality of life of residents depends on the quality of their relationship with the don, which often means, their level of loyalty and obedience to him" (p. 22). Ultimately, criminal groups link an individual's participation in illegal activities and their proof of loyalty, not just to financial rewards tied to criminal activity, but also, to their ability to access legitimate means of employment. However, supplying the community with access to both legal and illegal jobs is only one way is which criminal groups secure loyalties and establish power base within garrison communities.

The quality of life of residents is also improved by the allocation of merit-based housing within the community, and access to social welfare relief funded by the community leader himself. Under a powerful community leader, loyal residents and their families receive food, clothing, and money to pay for medical bills when they arise. Their children benefit from tuition payments, school uniforms and school supplies. Protection of these assets, as well as protection from physical harm within the community is often times also approved by the community leader.

Criminal groups carve out a crime free zone within the community in order to reinforce the benevolence of the criminal entity. Criminal groups provide for the community in exchange for higher levels of tolerance regarding the illegal activities that they establish within the community. While criminal residents may be gunmen, drug dealers, or petty hustlers and robbers outside the community, within the community the community leader and the lawful residents considers these individuals' community 
protectors and enforcers of the rules. Coupled with the sponsoring of community programs, criminal groups are "often regarded as champions of justice and social equality" (Gillespie \& McBride, 1996, p. 43). Beyond the provision of jobs, and social welfare, community leaders often times establish and spear head community programs such as youth groups, sports clubs, and education programs that help with afterschool tutoring and skills training. To bolster community morale and to promote the benefits that a community receptive to the presence of the criminal group receives, community leaders also host community events, such as community dances and holiday celebrations, as well as sponsor charity events like back to school treats and caring for the elderly. ${ }^{66}$ "By the mid-1980s, garrison communities and their internal political armies had become systematically entrenched in the transnational traffic of contraband, drugs, immigrants, and consumer items" (Ulysse 2007, p. 167). Through the local Jamaican economy, criminal group have established local centers of distribution for legal and illegal goods, and have contributed to a high level of acceptance for criminal markets in the local economy.

\section{Factoring in Informal Markets and the Free Market}

In the case of Jamaica, alongside the privatization of consumer markets and the liberalization of government control over legal markets, the firmly established culture for contraband and informal markets within Jamaica has strengthen and evolved. Similar to a number of other developing countries in the 1980s with a history of substantial smuggling and contraband distribution, Jamaica experienced an "explosive growth in its

\footnotetext{
${ }^{66}$ See excerpts from Christopher 'Dudus' Coke's plea to Judge Robert P. Patterson on September 07, 2011 http://jamaica-gleaner.com/pages/dudusguilty/coketojudgepatterson.pdf
} 
informal sector" as consumer markets liberalized under IMF policy guidelines (Gillespie \& McBride, 1996, p. 42). From as far back as the late seventeenth century, Jamaica has been a major center for contraband goods shipped to Central America and to other parts of the world.

Today, liberalization of the Jamaica market has allowed local criminal entities to become increasingly more organized and diverse in the type of illicit goods they are involved with, as well as the type of criminal networks and alliances they forge in the global market. More importantly, liberalization of local markets has allowed criminal elements to build networks and alliances with key members of the country's informal sector. Where chapter 6 references the middlemen who assist in the distribution of drugs, this section turns its attention to the informal players who help with the trafficking of illegal goods and activities. These include the fisherman, the career drug runner, the average Joe--trying to repay a favor or in desperate need of some cash--and more specifically, the higgler.

Derived from the word higgle- a less common term for haggle- small-scale female vendors called higglers play a central role in the local economy as they set up informal markets in areas surrounding bustling commerce and competitively peddle their wares to local consumers looking to avoid products laced with high taxes and controlled prices (Grindley, 2010). Deteriorating and fluctuating economic conditions in Jamaica have further created a greater space for higglers and the expansion of the informal, underground and criminal economies (Brown-Glaude, 2010). Moving back and forth from rural to urban areas, and later expanding their trade to overseas travels, higglers are 
middlemen of trade, who compete aggressively against the formal markets, and who are able to profit from the sale of both legal and illegal goods.

\section{The Informal Market and Informal actors such as the Jamaican Higgler}

History of Contraband Markets and the Jamaican Higgler: the Island started out as a safe haven for pirates in 1655 under English rule. English, French, and Dutch Pirates would attack Spanish settlements and seize Spanish shipments headed for its colonies in Latin American and the Caribbean. However, with a growing merchant class, piracy in Jamaica was squashed and new trade relationships based on smuggling and profits were forged among the colonies. The English and the Spanish established legal and contraband trade links in order to avoid the high taxes levied by the Spanish commercial system in attempts to control trade. Contraband trade between Central America and the British colonies in Central America and Jamaica were established, primarily through trade routes connected to the port of Trujillo in Honduras. ${ }^{1}$ Being the closest large island to the Gulf of Honduras, and hence Central America, Jamaica played an integral role in the Spanish contraband trade. The country helped to lower smuggling risks by providing storage for contraband goods from Central America until faster boats arrived to take the goods to countries in Northwestern Europe. It also provided storage in bulk to Spanish America before they were exported to various markets (Macleod, 2007).

Complimenting Jamaica's location as the center of contraband in the $18^{\text {th }}$ century was the growth of Jamaica's internal marketing system by enslaved Africans. Higglers became the backbone of a thriving internal market established in Jamaica to sell the surplus produce grown by enslaved Africans. 
[Once] plantation slavery were established, the slave owners faced the cost of feeding the enslaved in increasing numbers. The choice was either to import the food at significant cost, or to provide the incentives for the enslaved to feed themselves. They chose the latter...[The] produce was intended primarily for their own domestic use ... but eventually surpluses were created which were taken to local markets and exchanged for other commodities or sold for cash. The proceeds of these transactions accrued entirely to the slave (Bertram, 2010a, para 17).

Early markets peddled not just food, but also accommodated a vast array of commercial activities in major ports such as Port Royal, a safe haven for pirates and later the heart of contraband trade. Establishing themselves at the gateway of trade, Jamaican higglers sold a wide variety of provisions from commercial activities, and created an informal market for both legal and illegal goods. With the 1692 earthquake, destroying Port Royal, a new commercial market, known as the Coronation market, was created near the new commercial port in the city of Kingston. ${ }^{67}$ Today the market accommodates anywhere from 6,000 to 8,000 people on a daily basis (Gleaner T. , 2010).

Identifying the informal market and the Higgler: As the previous section points out, before the liberalization of local markets, there was a rich history of contraband trade between Jamaica and Central America, as well as between Jamaica, the U.S., and

\footnotetext{
${ }^{67}$ Bertram, A. (2010b, November 7). The Jamaican Higglers: Prosperity against the odds- part 2. Retrieved September 30, 2013, from The gleaner: jamaicagleaner.com/gleaner/20101107/focus/focus6.html paragraph 11. By 1775, "The port of Kingston conducted an extensive trade with Europe, Africa, North America and other colonies in the Caribbean region ... In 1775,639 vessels, manned by nearly 7,500 seamen were employed in the trade of the island. Of this total, 233 ships were engaged in trade with the British Isles, 299 with North America, 77 with Africa, and 30 with other Caribbean territories. An additional 45 small crafts were engaged in trade between Kingston and the island's out ports."
} 
European markets. The links, trade routes, and alliances established in the 18th century have played a role in the ease with which the marketing and distribution of cannabis took place in the 1950's, and subsequently of cocaine and guns in the 1980's. Distinct from the formal market, the informal market is primarily comprised of individuals whose economic activities are not regulated by the state. These individuals also do not enjoy any form of job security such as retirement packages and health benefits. Neither are their jobs, protected by labor laws. Further, according to Hert (1973) the informal sector is characterized by 1) jobs that require a low level of skill, 2) allows for easy entry, 3) generates low pay, and 4) generally attracts a immigrant workforce. However, as a Small Island Developing state, the informal sector in Jamaica is make up primarily of individuals specializing in illegal trade and street vendors as opposed to migrant laborers.

As a historically gendered term, Ulysse (2007) identifies the familial role of women to be another important factor along with, economic pressures, and the lack of job opportunities, as influencing the prevalence of higgling (p. 66). The typical higgler is ideally a female situated on the lower end of the income distribution possessing a low level of education. "Higgling, remain(s) one of the few occupations open to lower-class black females who are heading over one-third of the households in the country" (Ulysse, 2007, p. x). Despite these social barriers, there are a handful of women who have managed to transition into the middle class as higglers and who have managed to become a part of the formal economy, setting up shops and businesses. Further, there also are women from different ethnic backgrounds and lighter skin tones who have assumed the role of higgler in the Jamaican society, specializing on the trade of no agricultural goods. For the most part however, the term higgler remains gender and class specific. Chinese, 
Lebanese, White and brown-skinned females tend to sell mostly in shops. "Chinese Jamaicans are dominant actors in the retail grocery and banking sectors of the formal economy. [While], Lebanese Jamaicans are currently giants in retail, tourism, horseracing, and the industry and manufacturing sectors of the formal economy" (BrownGlaude 2011, pp. 42-43).

The transnational nature of the higgler. In the works of scholars such as Katzin (1960), Durant-Gonzalez (1984), and Brown-Glaude (2011), a highly complex and varied construct of the Jamaican higgler is revealed; a construct that helps to identify the role that higglers play as transnational actors who bridge illegal and informal markets. Katzin (1960), distinguishing between higglers on, " the basis of place of residence of seller, source of goods, regular occupation, number of hours spent buying and selling, and the amount of invested capital" (pp. 1-2). Further, she categorizes higglers as either rural or urban. 
Table 7. Category of Higglers

Rural Residents

1. Country People $\quad$ Women who sell produce grown by someone on their own households. Sell primarily in rural markets, or to town higglers

2. Weekend Country Higglers

Women from areas within 25 miles of Kingston who buy wholesale in Coronation and sell them at retail in the same market. Typically women who need to earn supplemental income

3. Country Higglers

Women who buy produce from growers near their rural homes and sell it in Coronation. Typically, provide a link between remote rural areas and the urban market. Sell at retail in local markets or sell to town higglers.

4. Planter Higglers or Mostly men who may grow part of their stock but differ Speculators from country higglers principally because they cover wider distances to buy large quantity of one commodity and transport it a greater distance often over 50 miles to market.

Kingston Residents

1. Tray Girls

2. Weekend Town

Women who carry their total stock on a tray or flat basket

Higglers

Women who buy wholesale from Country people and country higglers and sell in Coronation at retail on

3. Town Higglers Thursdays, Fridays, and Saturdays

4. Vendors Women who rent market stalls for which they pay a weekly fee that entitles them to sell at any time the market is open Town higglers, mostly men, who rent several stalls and specialize in one item, such as tomatoes

Research, later conducted by Durant-Gonzalez (1984) compliments Katzin (1960) study by refocusing a typology of higglers on the source of the goods, as opposed to the place of residence of the higgler. This is critical to understanding how these informal traders operated in domestic markets, based on complex and diverse networks of distributions. 
Farmer Vendor- $\quad$ sells produce from her own or her husband's farm

Farmer higgler- $\quad$ sells produce from other farms as well as her own

Country higgler- only buys and sells, resides in the rural areas; comes to town

during market days to sell her provisions

Town higgler- only buys and sells, is a resident in the towns, and operates only within the towns

\section{Seller of locally manufactured goods}

Within the categories proposed by Durant- Gonzalez (1984), higglers are not constraint by location. Rather, they fluidly interact, negotiate with, and transition between the various categories, as well as with other sellers and buyers at various levels of the internal market system- making them the ideal conduit for the movement of illegal goods/services between, and across, formal and informal markets. By the 1970s, expanding opportunities for global trade and rising levels of unemployment in Jamaica further contributed to an increasing volume and variation in how higglers evolved within the Jamaican society. Since the 1970s, higglering, within the Greater Kingston Metropolitan area, has become an even more specialized occupation. Not only have several different types of traders disappeared and new ones emerged, but also the scales of business and type of activity have changed considerably among different groups of local vendors. During the 1980s...the more traditional higglers, that is, the farmer-vendor and the farmer higglers are a declining minority, while town higglers are increasing (Uylesse 2007, p. 73) 
Access to global markets also allowed for a blurring of informal and illegal activities, products, and agents of trade as informal traders had access to expanding foreign markets. This occurred alongside the supported development of a local manufacturing sector heavily dependent on raw materials in the 1970s, with the support of the state. At the state level, there was also a notable shift in trading partners. Before the 1970s, Jamaica traded primarily with British markets. Now with its newly forged IMF partnership, import and exports occurred primarily between Jamaica and the United States. By the late 1970s, the rise of the 'sidewalk vendor' or higgler of mainly imported consumer goods rose to the forefront (Durant-Gonzalez, 1983, p. 2). Remarkably, poor urban women residing within inner-city areas- within and surrounding garrison communities- turned to self-employment as a survival strategy during tough economic times.

With a complex and diverse network of distribution between private sellers and buyers in the informal market already in place, it was easy for a new category of higglersthe modern higgler- to enter global markets and assume the role of informal commercial importers (ICI's). Distinguishing between the traditional and the modern higgler, BrownGlaude (2011) defines the modern higgler or the ICI, as a person who "specializes in the sale of manufactured goods they import from areas such as New York, Miami, other islands in the Caribbean, and more recently China" (p. 2). Capitalizing on the government's restriction on imports, higglers began to trade internationally, exporting local produce in exchange for the import restricted foreign manufactured goods. 
Compared to the traditional higgler who specializes in the sale of locally grown produce and good trades domestically within the internal market, the modern higgler assumes greater responsibility over a business that forges networks at both global and local levels, as well as at various stages of the buying and selling process. Although the higgler and the ICI are both the same, the average ICI distance themselves from the term higglers. Opting instead to be classify as small scale businesswomen who are better educated and positioned somewhere within the working class/ lower middle class strata. Informal Markets speckled with regulation: The informal economy is driven by the import and export of goods by Higglers. In 1982, the government attempted to minimize the competition that these individuals asserted over the formal business sector by implementing several regulatory polices. They were given the name of Informal Commercial Importers (ICIs) and then they were integrated into the local economy. Proving to be a contradiction of the term informal, street vendors and other members of the informal economy were relocated to designated market places with the help of agencies such as the Kingston and St Andrew Corporation (KSAC), the Metropolitan Parks and Markets (MPM), and the police (Brown-Glaude 2011). At locations such as Coronation Market, Papine market and Constant Spring Arcade in Kingston, vendors are assigned stalls, and permits to use the premises in exchange for stall fees and rents. Additionally, the state required that ICI's obtain no-funds licenses in order to qualify for higher import and foreign exchange quotas, as well as benefit from customs duty fees below market value. However, these regulations proved most restrictive to the activities of higglers. Import licenses required that higglers pay duties and fees that amount to 
nearly 45 percent of the value of their goods (Ulysse, 2007). ${ }^{68}$ It also required that they

pay past import duties, and could only import specific items determined by the state.

Whoever heard of higgler selling cameras and lawnmowers, not to mention motor vehicle parts and citizen band radios? These are some of the items listed for their quotas, while ladies sandals and garments, which comprised a large part of the current sales of higglers have been excluded from the list of 48 items, which they allowed to import (Ffrench, $1983 \mathrm{ctd}$ in Ulysse, 2007, p. 84-85).

Subsequently, a large majority of higglers prefers to remain unregistered and not become 'professional' importers. Opting to take their chances at customs lines and at enticing custom officials with the chance to pockets reduced duties if they turn a blind eye.

\section{Organized Nature of Smuggling}

The higgler as the middleman: The presence of large numbers of unregistered and informal higglers has helped to preserve and expand on the culture of smuggling, and on the sustainability of the various black markets that exist in the Jamaican economy. What this means is that "smuggling remains significant and may even become more organized. In order to survive under trade liberalization, smugglers' [and the criminal groups that hire smugglers'] rely on continued cost savings from avoiding legal import channels...this allows organized crime to compete alongside more traditional channels of distribution" (Gillespie \& McBride, 1996; 41). Ulysse (2007) highlights the trend of "suitcase trading" where primarily females able to travel back and forth between Jamaica

\footnotetext{
${ }^{68}$ Ulysse, G. A. (2007). Downtown Ladies: Informal commercial importers, a Haitian Anthropologist and self-making Jamaica. University of Chicago Press. Page 201 "customs and duty amounts have been rather high. It is calculated on the value of the shipped goods to which various duties are added. This includes an intial $25 \%$ in customs duties, another $15 \%$ general consumption tax added after the value of the goods total has been increased by $33.5 \%$. The $33.5 \%$ is charged because ICI import counterfeit merchandize that is of lower value.
} 
the United States, Canada, and the United Kingdom, export illegal goods outside of Jamaica. Paid in the currency of the country they travel to, these women often use the money from smuggling to purchase consumer goods and import them back to Jamaica for resale in local markets and arcades.

Marked distinctions that once existed between the female drug carriers/mules and the higgler have blurred as drug carriers are increasingly coexisting within the same transaction spaces. Where drug carriers/mules are linked to criminal markets and deal primarily in profiting form the transportation of drugs, arms and other high risk illegal products, it is not uncommon for higglers to subsidize their small-scale commercial business, or even to transition more fully towards the trading and transporting of high risk illicit products. Scholars such as Ulysses (2007) and Brown-Glaude (2011) indicate that ICI's gradually transition towards the smuggling of illegal goods because of saturated markets, as higglers tend to resale the same types of goods. Transitioning towards illegal trade is also a means of obtaining fast cash. ${ }^{69}$ Further, criminal groups into the drug industry, also recruit ICI's because of their experience as traders, as well as, because of their relationship to specific communities. Higglers generally reside within inner city areas and may be beholden to community leaders for protection or spoils received as a member of the community. Even in cases where higglers transition to the middle class they still maintain strong times to their communities via family members and established business relationships.

\footnotetext{
69 See, The Jamaica Gleaner. (2012, May 6). Abortion for Sale-Black Marker Thrives on Baby-Killing Pills. Retrieved September 30, 2013, from The Gleaner: http://jamaicagleaner.com/gleaner/20120506/lead/lead2.html; The Jamaica Observer. (2011b, July 15). Customs Seize $\$ 7.8$ million in Illegal Cigarettes. Retrieved September 30, 2013, from Jamaica Observer: www.jamaicaobserver.com/NEWS/Customs-seize--7-8-million-illegal-cigarettes
} 
In the case of Jamaica, the higgler provides an example of one way in which criminal groups forge alliances with other transnational actors, at various levels of cooperation. It is through these networks that criminal groups are able to simultaneously compete against some traditional channels of distribution, while using other types of traditional channels of distribution to compete. For example, while criminal groups maximize profits and evade legal channels by tapping into the informal linkages of the higgler, they are also utilizing the traditional informal linkages of higglers and trade relations that have been in place for decades. Given the nature of their job and their relationship to the formal and informal economy, higglers make an ideal middleman for illegal activity.

Unequal networks of interdependence: We know that Higglers have a culture of working between informal, contraband, and legal markets, and they have access to an intricate network of distribution that spans local and international connections. However, in most cases, Higglers do not carry much political advantage when it comes to negotiating their level of involvement in criminal activities where organized groups are involved. Despite being identified as specialized transnational groupings capable of forging trans-local ties, they are more acutely restrained by spaces of dependence (Cox 1998) and local embeddedness (Smith \& Guarnizo 1998) than the criminal groups they often times smuggle for. Where criminals groups are able to use their political relationships with the state--spaces of dependence-- to secure their continued existence and evolution and to carve out spaces of engagement, higglers are dependent on both the state and criminal groups within garrisons to mediate the flow of their relations. 
Spaces of dependence are framed by the local social interactions that guarantee a groups material well-being and their sense of significance (Cox 1998). Higglers are dependent on state decisions that aim to regulate their trade and that create legal areas such as markets for their operations [see figure 16]. Conversely, Higglers are also dependent on specific criminal groups to provide protection from within these designated zone or markets. This is because designated spaces for trade are at times located in areas that are sometimes risky to do business in, or even to commute to for members of some community's versus others. As a result, some vendors turn to the streets to sell their goods, where they also are forced to pay for protection from the common thief. Whether in markets or on the street higglers are forced to play "rent" to area gangs for protection. This gets more complicated when we factor in the spatial division of downtown Kingston into political factions that violently clash with each other daily, especially during election years. These political factions often are tied into Kingston's drug culture, in which an area drug leader or don, presides over each faction and demands loyalty from area residents. (Brown-Glaude, 2011, p. 155). Providing further perspective, Ulysse (2007) points out that the central commercial district in downtown Jamaica [known as Parade] is surrounded in fact by these dangerous political constituencies (p. 164). While vendors must juggle the politics of location, markets represent open zone for shoppers from almost all walks of life, except in cases where communities are violently at war. It is not unusual for these vendor areas to experience roadblocks and become temporary no-go zones from time to time [see figure 17]. 


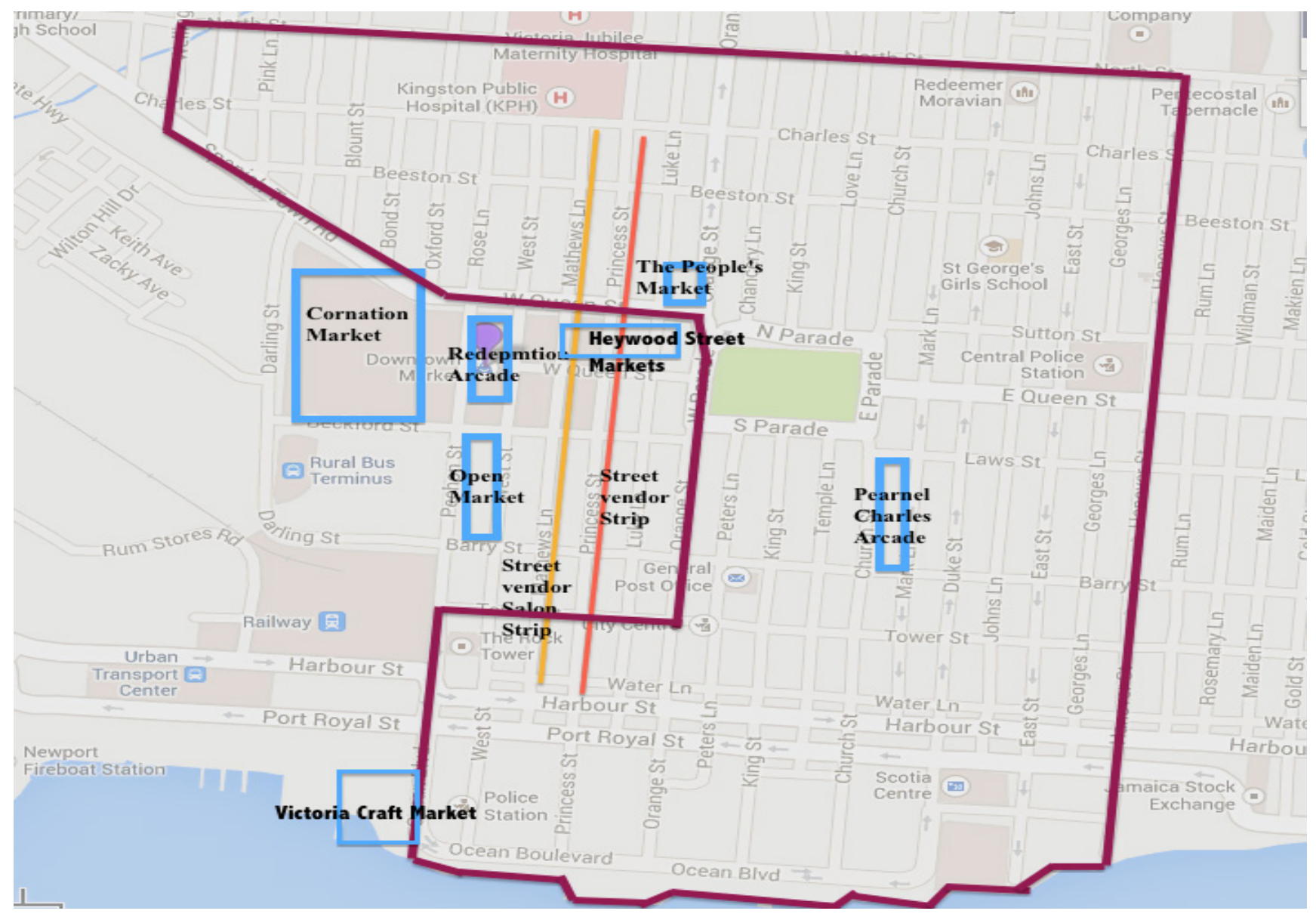

Figure 22. Downtown Arcades, Markets, \& Business District

Note. Figure shows the location of a few of the markets and arcades in the Downtown area. The Business district of this area is outlined in red. Note there are also a number of smaller markets and informal vending areas not identified on this map 


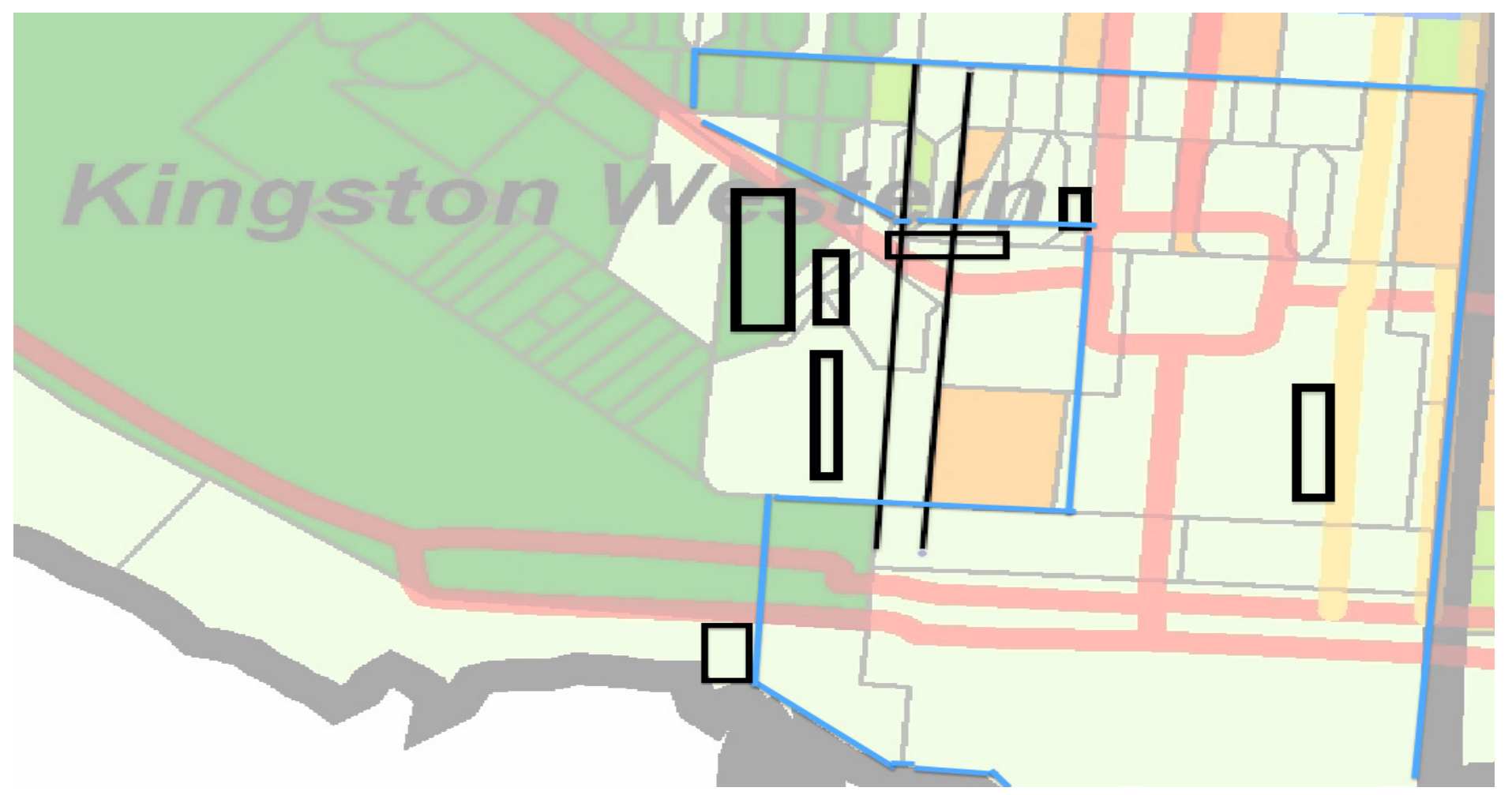

Figure 23. Proximity of Business District \& Markets to Garrisons

Note. Figure uses data from Mona Geolinformatics polling division map of Kingston and St Andrew during the 2007 General elections. Dark green shaded areas represent voting blocks where 90-100 percent of the votes supported the Jamaica Labour Party [JLP]. Dark Orange shaded areas represent voting blocks where 90-100 percent of the votes supported the People's National Party [PNP]. Ares with 90-100 percent of voted are defined as Garrisons communities. 


\section{Summary}

It is important to understand that transnational interactions are not just about nonstate actors accessing the global from home, more precisely; they are also about the connections forged from one location to another; that is, from the local to the local; higglers and suitcase traders act as middlemen allowing these links to be forged. Their access to various channels of distribution and their complex interactions with the Jamaican state and criminal groups has resulted in a growing and evolving market for illegal goods such as cigarettes, prescription medication, and drugs, and the forging of unequal networks of interactions with criminal groups.

This chapter also highlights how these criminal groups were able to obtain an economic foothold and to ascend to such a high economic status within urban communities. Major changes to community-based development in the 1980s because of the liberalization and privatization of the Jamaican economy created a vacuum in community development. The scaling back of the size and role of the state, as well as the limited restructuring of the labor market during that period, not only led to the immediate withdrawn of resources to urban communities, but it also failed to address the increasing unemployment. Privatization and liberalization did however allow criminal groups access to illegal markets, and to new avenue for income. Through access to these markets, criminal groups were able to replicate the clientelistic practices that were in place before the 80's. "By the mid-1980s garrison communities and their internal political armies had become systematically entrenched in the transnational traffic of contraband, drugs, immigrants, and consumer goods" (Uylesses, 2007, pg. 167) 
As these criminal groups become more organized and economically efficient at making a profit, they have sought to diversify into a multiplicity of criminal activities such as rent seeking among businesses in exchange for protection. The increased use of violence is viewed also as an economic tool to eliminate competition to protect the evolving nature and profits of the organization. 


\section{CHAPTER 8}

\section{CONCLUSION}

The current study has set out to explore the transnational nature of the Jamaican garrison, and has sought to answer the questions: how have criminal entities within Jamaica's garrisons been able to strengthen their power base in relation to the Jamaican state, as well as how have they managed to offset the state's monopoly on power? Using Nye and Keohane's (1971) understanding of transnational relations in an analysis of the garrison, the dissertation asserts that network based criminal groupings residing within garrisons are directly shaping the behavior and policy goals of the Jamaican state by forming coalitions and interactions across state boundaries. These coalitions and interactions involve a wide cross section of non-state actors both criminal and legal, as well as corruptible elements of government.

The give and take that occurs between the Jamaican state and garrison further reveals that several of the transnational interactions that occur happen without these network based criminal groupings leaving Jamaica, or even leaving their bases of operation within the garrison. By focusing criminal activity around global activities such as drug trafficking, weapons trafficking, and outsourcing violence, small criminal groupings are able to exert global influence while remaining local. In addition, the transnational activities of network based criminal groupings carry significant political consequences, as the transnational activities that take place within the garrison influence state decision-making aimed at eradicating the political and economic bases of the criminal groups, within these urban areas. 


\section{Empirical Findings}

The main empirical findings of the current study have been explored and summarized within chapters four through seven and draw the following conclusions respectively:

1. How have illegal entities within Jamaica's garrisons been able to strengthen their power base in relation to the Jamaican state?

Finding \#1: The Jamaican state has allowed criminal power structures to become an established part of the political system. Criminal power structures located with urban slums located in the capital city, at the heart of Jamaica's commercial center have been institutionalized by the Jamaican state through the provision of public housing, free access to utilities, and access to jobs in key communities in exchange for political votes and loyalties. The politicized nature of these communities, has helped to construct a group identity that shapes urban land appropriation, the outward expansion of garrisons, and the nature of level of violence that occurs with the country

Finding \#2: Criminal entities employ organizational and power structures that best enable them to protect themselves within limited spatial boundaries and that allow them unlimited access to global markets beyond the scope of the state. Employing a combination of hierarchical and networks structures, garrison groupings do not need to be highly sophisticated in order to evade the law, successfully profit from illegal activity, establish a monopoly within a specific market, or to 
coordinate and mediate political interests. The multiplicity of garrisons and gang types that exist within Jamaica, as well as the interactions forged with corrupt elements of the state allow for a fluid and complex network of interactions that is hard to track or to do away with.

2. How have they managed to offset the state's monopoly on power?

Finding \# 3: Network based criminal groupings have assumed a more influential role in the distribution and use of violence, which has allowed them to renegotiate the power advantage of the state. Not only has violence taken on a structural element as a byproduct of the development of politics in Jamaica, but also network based criminal groupings use violence and corruption as tools to protect, maintain, and expand their illegal activities. Because globalization has created a space for violent criminal activities to increase in scope and in intensity, network based criminal groupings have constructed a type of violence that is transnational in nature. As a tool, violence is an established part of the market interactions that take place between non-state actors both within the garrison and between localities outside of the state. Transnational violence is a commodity packaged alongside other commodities that are violent in nature.

Finding \#4: Network based criminal groupings have taken advantage of the liberalization and privatization of the Jamaican economy. Neoliberal policies have resulted in the scaling back of the role and size of the state in community development and have allowed private entities the 


\section{opportunity to govern neglected communities. These policies have}

increased private access to criminal markets. Profits earned from access to criminal global markets have allowed network based criminal groupings to replicate the clientelistic practices historically started by the state. Privatization policies have reduced the role of the state in community development, criminal entities has been able to easily fill the vacuum created by the state. This has further allowed illegal organizations to establish community loyalty and to set up governance systems that either directly or indirectly challenge the state's ability to provide public services, to address the issue of corruption, and to monitor informal markets and businesses.

Collectively, these empirical conclusions provide clear support for the dissertation's theoretical implications. Jamaica's garrisons are not only transnational, but as the following figure below illustrates the case of Jamaica reveals a progressive deepening of transnationalization within its borders. As it relates to the garrisons, transnationalization has deepened beginning with Jamaica's independence in the 1960s, its interaction with intergovernmental organizations such as the World Bank and the IMF in the 1980's and 1990s, and this process continues to strengthen with Jamaica's increased collaboration with other states within the international realm. 


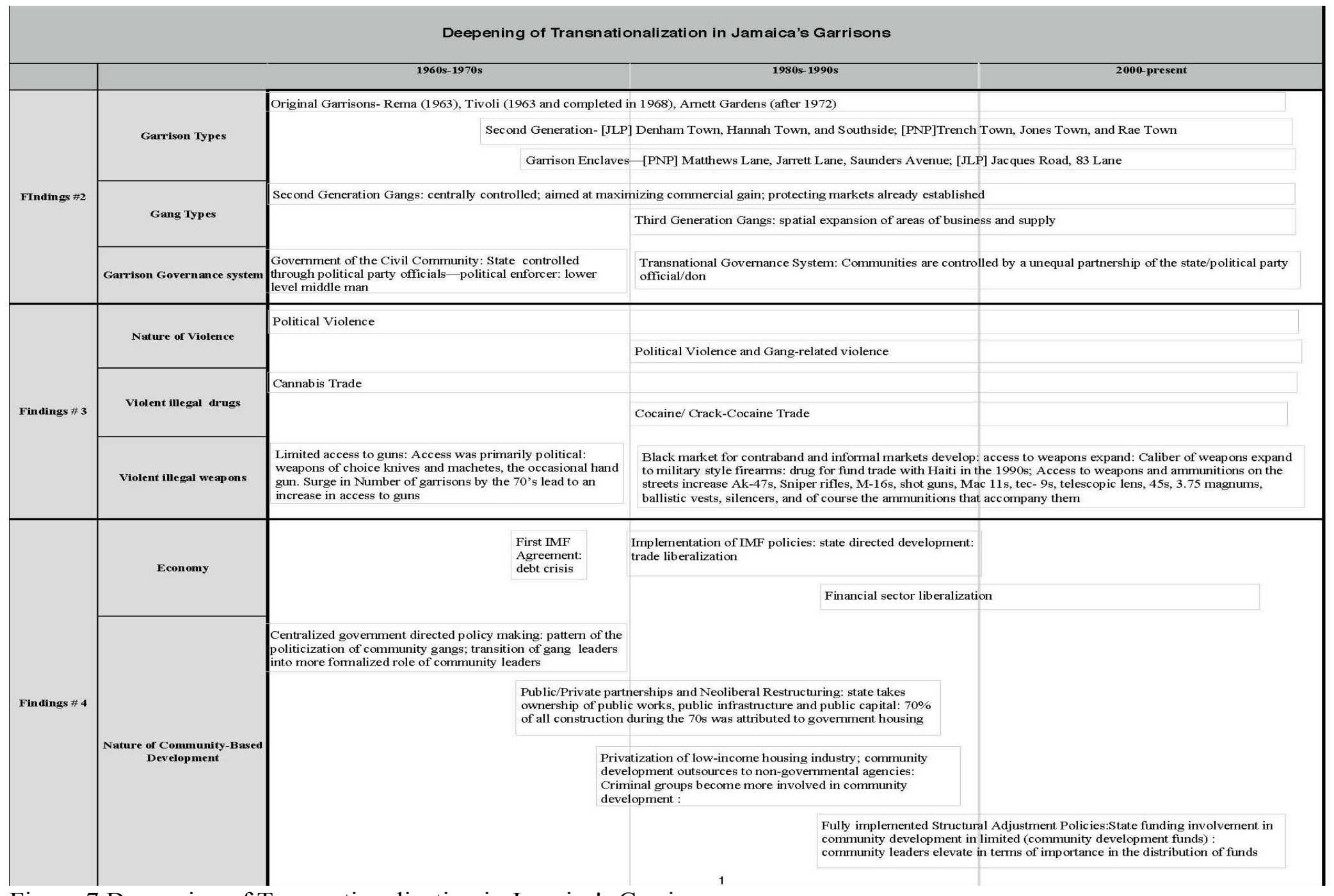

Figure 7 Deepening of Transnationalization in Jamaica's Garrisons 


\section{Theoretical Implications}

While there has been extensive research done on the Jamaica garrison, the literature, for the most part, has tended to focus on the evolution of garrison politics and how garrisons have become institutional power structures (Figuera, Harriott, and Satchell, 2008; Sives, 2010; Gray, 2004; Headley, 1996; Stone, 1983; Figuera and Sives, 2002). A few scholars have chosen to focus on the expansion of transnational criminal activity and the economic expansion of Jamaican gangs in the United States, Britain, and Canada (Harriott, 2008; Gunst, 2003). While more recent works examine the use of violence within the garrison (Charles, 2012; Sives, 2010, 2012), the role and influence of dons within the garrison (Sives, 2012; Blake, 2012), and the challenges to governance that the state faces as a result of the garrison dynamic (Sives, 2010; Johnson, 2011).

However, when acknowledging the growing prevalence of transnational criminal groups and the increases in crime and violent activity, state policies are framed consistently around the notion that there are only two types of criminal groups in Jamaica. Primary focus goes towards criminal groups that are considered large cohesive entities that shadow the state. These entities are seen as transnational once they establish cells in other states, and take part in global criminal markets such as drugs and weapons trafficking. Alternatively, less attention is paid to small local gangs that are concerned with protecting territory and securing minor political spoils such as jobs and housing. These small gangs are seen as endemic to the urban slums.

The literature on garrisons seems to overlook the fact that both criminal typologies aspire for the same outcomes, and indeed are connected to each other. Like all other types of private entities, criminal groups within the garrison also set out to 
maximize profits. In understanding that the garrison is comprised of network based criminal groupings that are transnational in nature, theory building should move from ranking the importance of criminal groups by their level of profit maximization, to one that focuses on the interactions that take place among a wide cross section of individuals and groups within, and across, various localities. Only by learning from the nature of these multiple and complex alliance and networks can state policies ever really assess the implications that these interactions have on the state. Studying the transnational nature of these criminal activities helps us to identify more accurately the strategies employed by these entities, the opportunities gained by them, and their significance on state policy making.

\section{Policy Implications}

Applying the extradition of Christopher 'Dudus' Coke: The implications of the growth, and in some cases the restructuring, of more evasive and organized network based criminal groupings within the garrisons can be examine most closely by assessing the recently publicized 2010 government mishandled extradition process of Christopher "Dudus" Coke. This case highlights not only the nature of alliances formed between state and non-state actors, but it also gives some insight into how the transnational identity of criminal groups can dampen the importance of local identities- such as political identities-when alliances between competing groups are necessary for the entity's survival.

In August 2009, the United States Drug Enforcement Administration (DEA) formally requested the Jamaican government, to begin the extradition process of one of its most infamous citizens, Christopher "Dudus" Coke. Coke was identified as a local 
gang leader of one of Jamaica's most formidable garrisons known as Tivoli Gardens, and an alleged drug kingpin, by the United States. He was wanted by the United States in order to face charges of drugs and weapons trafficking.

What makes this extradition case so unique is not so much the timeframe in which it took place or the outcome. Rather, what makes this extradition case important is that the dynamic that took place between the Obama administration and the Jamaican government highlights the increasing complexity of the garrison-state relationship, as well as how network based criminal groupings have been able to leverage power against the local state and expand its reach globally, all while remaining firmly grounded locally. The precarious position faced by the Jamaican government was that Coke presided over an urban area that is located within the voting constituency of the then current governing political party, and that more notably, is historically identified as a key voting block for that political party's electoral success. Further, it is also significant to point out that Coke presided over an urban area that has historically been the political constituency of 'choice' for every political figure within the Jamaica labour Party that has served in the role of Prime Minister of the country. This marriage between Tivoli Gardens and the head of the Jamaica Labour Party (JLP) has existed from even before it become the first formally established garrison in the mid 1960's to early 1970's, by former Prime Minister, Edward Seaga (Spaulding, 2011). ${ }^{70}$

\footnotetext{
${ }^{70}$ Spaulding, G. (2011, October 2). The Gleaner. Retrieved October 1, 2013, from Will Golding's Tivoli Heir...Mash down Garrison Politics?: jamaica-gleaner.com/gleaner/20111002/focus/focus51.html. Since 1944, some of the biggest names in the Jamaica Labour Party (JLP) have represented the constituency. These include the JLP founder, Alexander Bustamante; Donald Sangster; Hugh Shearer; Edward Seaga and Golding, all of whom emerged as prime ministers during their political career.
} 
Paving the way for the establishment of other garrisons in the country, Tivoli Gardens is often times colloquially termed the "mother of all garrisons." It stands out in every Jamaicans mind, first as a reminder of the ruthlessness of the criminal groups that exist within its boundaries and second, as a prime example of the ability of criminal groupings to transform themselves from simple urban gangs to more clearly identified transnational entities. Third the case of Tivoli highlights how criminal groups have manage to form alliances across political affiliations and between a wide typology of gangs and garrison constructs in order to secure more direct involvement in the day to day politics of the country, and to maximize profits. The unnecessarily lengthy ninemonth extradition of Coke from August 2009 to June 2010, led the then ruling government's attempt to dismantle one of its own politically backed garrisons under public pressure.

Over the course of a month long state of emergency, the Jamaican government attempted to detain Coke. During that timeframe, the police and the military were deployed to the capital's urban areas to defend against armed supporters of Coke. Before the "Tivoli Incursion" which ended with the death of 77 civilians and 4 police officers (Sheil \& Davis, 2010), Coke supporter had already initiated an attack on the state by torching four police stations (The Associated Press, 2010; The Gleaner, 2010c) and by engaging in sporadic shootouts with the armed forces. Urban enclaves within Tivoli Gardens and affiliated areas such as Denham Town began constructing barricades aimed at limiting access, relaying information, and defending Tivoli Gardens from an attack by the state. Before the extradition of Christopher Coke, criminal groupings also used their networks to organize peaceful demonstrations among the women and children of these 
urban communities, professing the innocence of their just and benevolent community leader.

Policy implications within the Jamaican state: Immediately after the incursion, the Jamaican security forces took control of the community and its surrounding area. In an attempt to reestablish the role of the state, there has been an increased presence of security forces in the area, and the government has allowed the water and electric companies to regularize utilities by removing illegal connections and setting up billable accounts. Sixteen months after the incursion on September 25, 2011, Prime Minister Bruce Golding resigned from office. His resignation took place in the wake of criticism concerning the mismanagement of his office and the abuse of the political power. Another leader within the JLP party subsequently replaced him. Ultimately, this conflictridden extradition fueled a series of public debates among government officials and the public. It has also highlighted the entrenched relationship that exists between legal entities of the state--political parties-- and the garrisons that reside within the country.

Beyond the debate-- as the majority of respondents in the current study have noted--there has yet to be any real attempt to disable the garrison. Disregard to its network based structure has lead to the overall assumption that the extradition of Coke has solved the government's problem. This has not been the case:

- March 2011- "gunmen brazenly shot up a police station and later swarmed inside a public hospital to rob [medical personnel] just outside the [city's] capital" (McFadden, 2011, para. 1). The authorities later informed the public that this was considered the job of the Klansman gang-- another prominent 
criminal network-- in retaliation for the deaths of three of its members by security forces.

- September, 2011- leaders from the JLP such as former Prime Minister Edward Seaga, Mayor Desmond McKenzie, and Senator Tom Tavares-Finson attend the funeral of Christopher 'Dudus' Coke's mother. Mayor McKenzie, who also moderated the tribute segment of the service and identified her as an outstanding daughter of West Kingston, gave the eulogy. "Despite the challenges she faced, West Kingston will not be the same without her" (Dennis 2011).

- August, 2012-Commissioner of Customs reports that the customs department has seen an influx in the number of marijuana, hashish, and cocaine seizures, and indicated that cocaine trafficking in Jamaica is on the rise. The Commissioner also reported the seizure of large quantities of cash, and an increase in the number of incident in which ammunition, firearms, illegal cigarettes, debit/credit cards and money orders, were confiscated (Daviot, 2012).

- March 2013- resurgence in crime within several West Kingston communities as 'young thugs' are reported to brazenly display their guns in the area and taking part in several shootings and murders aimed at establishing clout and controlling the area (Daviot, 2012; Spaulding, 2013).

- May 2013- the re-emergence of the cocaine trade in areas outside of western Kingston such as Montego Bay and St James. The police seized 66 kilograms of cocaine with an estimated street value of \$264 million in just one vehicle 
searched. Authorities have also used anti-crime legislation to investigate more than $\$ 300$ million worth of high-end residences that are assumed to be affiliated with an international drug and money-laundering network (Sinclair, 2013).

- August 2013- despite police presence, factions within West Kingston are reportedly fighting for control of the area. "Two members of the Coke family are at the head of one faction, while the other includes some of Massop's relatives and former associates" (Helps H. G., 2013, para. 12).

These events represent just a few highlighted instances that emphasize the transnational nature of network based criminal groupings within the garrison. They also signal that despite the massive effort taken by the Jamaican state to reclaim a specific community from network based criminal groupings it is still business as usual.

There is little doubt that this case illustrates the dynamic that exists between the state and the garrison. By responding to the extradition warrant for Christopher Coke, and by the security forces successfully infiltrating Tivoli Garden, the state was able to flex its power and assert its dominance in the short term. Within an increasingly transnational realm, dismantling the face of an organization does not remove its influence from the society. The examples included above display how network base criminal groups have been able to continuously challenge and undermine the authority of the state. In specific reference to Tivoli Gardens, these more recent challenges to the state are occurring in the midst of the increased police presence within the community. Thus, revealing a sort of brazen opposition to state authority. 
As a result, the dissertation has argued that transnational criminal actors must be locally embedded within specific localities and that they require cooperation from corruptible elements of the state in order to mediate and negotiate their needs. It also warns that network based criminal groupings will continue to take advantage of global markets and local relationships within the state aiming at maximizing profits and ensuring its survival. While this indicates that the state will not wither away, it does indicate that the state's authority to effectively govern is limited in fighting transnational criminal entities at this time in Jamaica's political evolution.

Policy implications between states: Compounding Jamaica's struggles with the institutionalization of suppliers of illegal goods and activities within its borders is its international commitment to eradicate the supply side of illegal activities taking place around the globe. One such aspect of international cooperation involves the rich history of interaction and a shared commitment to cooperation between Jamaica and the United States. As a relatively stable parliamentary system, with a long history of democracy, Jamaica has over 80 major U.S. investors and an equally long history of attracting foreign direct investments from the U.S, since its independence in $1962 .^{71}$

More recently, under the Obama administration, the U.S. has sought to balance soft-side development assistance with hard-side security and counter drug assistance aimed at overhauling its foreign policy plan for the Caribbean region. This overhaul is in preparation for the resurgence of the Caribbean as a primary drug trafficking corridor.

\footnotetext{
${ }^{71}$ See: U.S. Department of Commerce (U.S. and Foreign Commercial Service) and U.S. Department of state. Doing Business in Jamaica: A Country Commercial Guide for U.S. Companies, February 18, 2010. Both the U.S.AID and the Peace Corp have provided assistance to Jamaica since its independence; See Seelke, C. R., Wyler, L. S., Beittel, J. S., \& Sullivan, M. P. (2011, May 12). Latin America and the Caribbean: Illicit Drug trafficking and the U.S. Counterdrug Programs. CRC Report for Congress . Congressional Research Service.
} 
The increasing interconnectedness and interdependence between states means that Jamaica's domestic struggles over the extradition of Coke unavoidably spilled over into its relationship with the U.S. and other states.

Regarding the recent extradition, Coke is not the first Jamaica citizen to be charged with federal drug and weapons trafficking by the United State. In fact, his extradition was just one of 16 persons requested to be extradited to the United States in 2009 (Sinclair \& Spaulding, 2009) under an extradition treaty agreement between the U.S and Jamaica signed in 1983, and put into effect in $1991 .{ }^{72}$ Despite the Jamaican government's initial disregard of the extradition of Coke on procedural grounds that the extradition did not meet the laws of the Jamaican state ${ }^{73}$ the U.S. government stepped up its pressure on Jamaica by:

\footnotetext{
${ }^{72}$ The 1983 Treaty supersedes the United States-United Kingdom Treaty on Extradition of 1931, which was made applicable to Jamaica, a former British colony, in 1935. See: Commentary. (2009, December 8). EDITORIAL- Government must honor its Treaty Obligations. Retrieved October 1, 2013, from The Jamaica Gleaner: mobile.jamaica-a.com/20091208/cleisure/cleisure1.php. It has been subsequently renegotiated on two occasions: the first in 1983 under the Jamaica Labour Party (JLP) Administration, and the second in 1991 under the People's National Party (PNP) Administration. See: Sinclair, G., \& Spaulding, G. (2009, October 5). Dudus has Company- Extradition Files rveal prominent names- State says papers not ready for signature. Retrieved October 1, 2013, from The Jamaica Gleaner: mobile.jamaicagleaner.com/20091005/lead/lead1.php; Wilson, H. (2010, March 17). Extradition and Ministerial Discretion. Retrieved October 1, 2013, from The Jamaica Gleaner: jamaicagleaner.com/gleaner/20100317/lead/lead7.html

${ }^{73}$ Despite having the right to refuse an extradition request, the actions of the prime minister and his administration were inconsistent with how previous extradition processes were handled. This implies that Coke was a special circumstance because of his donmanship over Tivoli Gardens and his relationship with the political party in power.
} 
1. Withholding the assignment of a new U.S. Ambassador to Jamaica ${ }^{74}$

2. The unexpected cancellation of work permits and visas of prominent entertainers and business officials ${ }^{75}$

3. Increasing the presence of agents from the Drug Enforcement Agency (DEA) and the Central Intelligence Agency (CIA), ${ }^{76}$ and

4. Publishing negative finding on Jamaica's commitment to cooperate internationally to eradicate criminal entities in the International Narcotics Control Strategy Report (INCSR). ${ }^{77}$

Given the economic and political climate of Jamaica and its interdependent and interconnected relationship with the U.S., it is likely that the extradition of Christopher Coke underscores how the U.S. may act in asymmetrical relationships with countries like Jamaica.

\footnotetext{
${ }^{74}$ See: Francis-Jackson, C. (2009, January 16). Saying Goodbye to the US Ambassador. Retrieved October 2, 2013, from The Jamaica Gleaner: jamaica-gleaner.com/gleaner/20090116/social/social2.html; The Jamaica Gleaner. (2010a, January 13). Dudus Still Wanted- US Govenrment will not withdraw request for Coke, but won't use power to get him extradited. Retrieved October 2, 2013, from The Jamaica Gleaner: jamaica-gleaner.com/gleaner/20100113/lead/lead1.html; Gleaner, T. J. (2010d, July 27). US to Rule On Ambassador To Jamaica Today. Retrieved October 2, 2013, from The Jamaica Gleaner: jamaicagleaner.com/gleaner/20100727/lead/lead3.html

75 The Jamaica Gleaner. (2010b, February 26). Wayne Chen's US Visa Cancelled. Retrieved October 2, 2013, from The Jamaica Gleaner: jamaica-gleaner.com/gleaner/20100226/lead/lead3.html

${ }^{76}$ See: The Jamaica Observer. (2010a, April 11). US Agents Stream into Jamaica. Retrieved October 2, 2013, from The Jamaica Observer: www.jamaicaobserver.com/news/covert-agents-in-jamaica

77 See: United States Department of State. (March 2010). International Narcotics Control Strategy Report volume 1 Drug and Chemical Control. Bureau for International Narcotics and Law Enforcement Affairs; Sullivan, M. P. (2010). Jamaica: Background and U.S. Relations. Congressional Research Service.
} 
Policy implications between state and non-state actors. The garrisonization of Jamaica is analogous to a growing number of states that confront the transnationalization of illegal activities from communities within their borders, a transnationalization that highlights kinds of globalization. Within an increasingly globalized international system, several other states may face similar dilemmas: Brazil and its Favelas (Arias, 2006; Arias \& Davis Rodriques, 2006), South Africa and its slums (Standing, 2005; 2006), and Russian and its slums (Bagley 2004).

According to Arias (2006), with the emergence of the drug trafficking industry transnational networks have become a hallmark of globalization in Brazil's Favelas from the mid 1980s. The impoverished nature of these communities in addition to the their high levels of density ${ }^{78}$ have made them conducive to the drug market. Favelas at varying times and to varying degrees manufacture drugs, store and distribute these drugs to criminal retailers, and setup and run sales of drugs to clients. By utilizing the same economic avenues that allowed "legitimate businesses to expand, speed up, and prosper; especially the information technology and telecommunications revolution, the greater ease of travel and the deregulation of financial markets" Standing (2006, p. 60), refers to this process as the corporatization of street gangs, such as those found in South Africa. ${ }^{79}$ No longer is gang membership characterized solely by cultural and social characteristics such as group identity, self-protection, pride, boredom or turf; globalization has allowed

\footnotetext{
${ }^{78}$ Study from Brazilian Institute of Geography and Statistics reported that based on 2010 census, 11.4 million Brazilians (6\%) live in favelas. Within the 20 metropolitan areas in Brazil 88.6\% of the population, reside within favelas.

${ }^{79}$ Standing, A. (2006). Organized Crime: A study from the Cape Flats. South Africa: Institute for Security Studies. He cautions however, that not all street gangs are destined to become drug dealing, profit maximizing businesses, organized around paying off state officials. Neither are they always a part of the organized crime network.
} 
for changes to gang formation where the bottom line now is money (Ramatlakane ctd. in Standing, 2006, pp. 36-37). As such, the ability of cocaine drug traffickers to access and take part in illegal markets in countries like Brazil and South Africa has proven to be problematic for the legitimate state institutions.

The relevance of states with specific localities has been off set by criminal networks, especially when we look at the state's ability to control crime, enforce the rule of law, and to provide basic welfare for its citizens. The Brazilian state's legitimate authority within favelas, as with the Jamaican state's declining authority within garrisons, has been offset by the ability of drug traffickers to use proceeds from their illegal activities to provide residents of favelas with housing and employment, while providing the community at large with security and infrastructure. Developing "parallel structures and an alternative rule of law" (Goldstein, 2003, p. 200) drug traffickers reduce the presence of the state within these communities, as well as their purpose. They build legitimacy among residents and within these communities by becoming community financers, defenders, supporters, and allies. Further, "like the state, organized criminals use violence to impose order and work with civic leaders to establish their legitimacy" (Arias, 2006, p. 300). Although there is an expected correlation between crime and criminal activity, Neuwirth (2004) points out that there are generally very low levels of crime within communities that are governed by criminal networks. In actuality, the presence of high caliber weapons, are confined to specific times of day, and are associated with the protection of the drug dealers' product and business rather than to any day-to-day crime carried out within these communities. 
In fact, like the Jamaican Garrison everyday crimes such as robberies, muggings, break-ins and assaults, do not take place among residents within the favelas. The drug dealers provide these communities with security and protection in exchange for their unquestioned access and use of these localities to carry out illicit activity. As Arias (2006a, 2006b) very importantly indicates, this altered relationship between these localities and drug traffickers is only possible within communities that have an established patron-client relationship with the state. By devaluing the purpose of the state, drug traffickers have shifted patron-client relationships to those interactions formed between themselves and the favelas. The drug traffickers' possession of these high power weapons not only allow them to mete out swift justice on behalf of residents, but they also serve as are a daily reminder of the power of the drug trafficker and the consequences for turning against them.

In crime-free favelas such as Rocinha, it is also uncommon to see businesses forging relationships with drug traffickers where businesses provide drug traffickers with regular payments for protection and a crime-free environment- similar to the system of extortion established between businesses and gangs in Jamaica's capital. Neuwirth (2004) indicates that at times, these interactions as actually willingly entered into by local businesses (p. 256). In addition to protection payments, the owner of businesses located within some favelas normally attend parties hosted by drug traffickers and frequent receive friendly store visits from members of the drug gangs inquiring about any issues or concerns these stores might have with their customers (Neuwirth, 2004, p. 258).

However, in order to reinforce their newly negotiated power leverage among community residents, Arias (2006) argues that drug traffickers also need to more 
specifically foster a strong relationship with civil society groups and non-profit organizations that set up in the community. In the case of Brazil, these civil society groups include resident associations, Evangelical Christian, or Catholic Church base. This relationship with the civil society segments of the favelas allows drug traffickers to develop an equally strong relationship with state actors. By building support from civil society groups within the criminal governed communities, as well as with actors outside of the favelas, drug traffickers become political actors. By thinking globally about their stake in the drug industry, these criminal groups recognize that there political power is reinforced not only by becoming a benefactor to urban slums, but also by maintaining the clout that comes with forging legitimate political ties. This has proven most successful in the case of the Jamaican garrison.

Similar to how successful criminal networks strive to develop flexible linkages and networks around the world, drug traffickers form flexible local linkages and networks based on mutual interests with local entities both inside and outside of the favelas (Arias, 2006). The flexibility of interacting via networks of interactions allowed the drug traffickers to develop long-term relationships based on trust with various groups within the state. Networks allow drug traffickers to control the flow of private information while maintain multiple interactions with several entities simultaneously, each one based on a specialized set of actors with a shared interest.

With profit making a critical characteristic of criminal entities, short-term economic alliances are formed more readily amongst transnational actors, despite preexisting historical formations based on ethnic or familial structures, and on community history. Between communities and criminal groups in Colombia, Italy, 
Mexico, Russia, and Jamaica, interactions forged along primarily economic interests help to blur the lines between legal and criminal activities and interactions, and contribute to their overall ability to evade the state. Within the Sverdlovsk region of Russia since the 1990s, traditional criminal groups such as the Vory. V. Zakone, have diminished in influence making way for a new form of economically motivated criminal networks known as the Uralmash. These criminal networks operate in spheres of influences defined by the splitting of cities such as Yekaterinburg into territorially distinct sectors (Finchenauer \& Voronin, 2001). Mutual interests and the functional nature of these networks allow the Uralmash criminal networks to maintain exclusive membership, apply the systematic use of violence, and to specialize in types of crime and divisions of labor.

In Brazil, South Africa, Russian, and Jamaica these communities represent an autonomous space for the financially and socially disempowered. The dark side of globalization has provided criminal entities not only with a space in which to operate, but it has also fostered an increasing demand for illegal goods and activities. "Globalization processes have increased the scale and scope of transnational exchange for legitimate and criminal enterprises alike" (Conway \& Heynen, 2006, p. 95). Developing competing governance structures to the local government, garrisons play an increasing role in determining the role of political behavior and legitimacy within the state.

A pattern of illicit transnational interactions utilizing the global interaction processes of communication, transportation finance and travel is discussed within specific communities in Brazil, South Africa, Russian, and Jamaica. The influence of globalization on the rise of network based criminal groupings in Jamaica's garrisons is not unique. These communities represent an autonomous space for the financially and 
socially disempowered. The dark side of globalization has provided criminal entities not only with a space in which to operate, but it has also fostered an increasing demand for illegal goods and activities. The dissertation has argued that transnational criminal actors in Jamaica are embedded locally within specific localities, and that they require cooperation from corruptible elements of the state in order to mediate and negotiate their needs. The dissertation also warns that network based criminal groupings will continue to take advantage of global markets and local relationships with the state with the aim of maximizing profits and ensuring their survival. The case of Jamaica reveals a deepening of transnationalization occurring within Jamaica's garrisons beginning in the mid 1960s. Finally, while this indicates that the state will not wither away, the dissertation does indicate that the state 's authority to effectively govern is limited in fighting transnational criminal entities at this time in Jamaica's political evolution.

\section{Recommendations for Future Research}

Considerable more work will need to be done on the transnational nature of the Jamaican garrison, the prevalence of transnational criminal groupings within other islands of the Caribbean, and on a cross-national study on the politics of transnational criminal group.

First, the current study focused specifically on the growth of the garrison phenomena with the Kingston Metropolitan Area (KMA). By only focusing on this specific area, the current study does not account for the growth and outward expansion of garrisons to other urban areas across the country such as areas of St Catherine and St James. Nor does it account for the spread of garrison areas, and the violence associated 
with it, to uptown low-income zones (Bailey, 2007) ${ }^{80}$ "'These are squatter communities at various stages of evolution, occupying lands considered unsafe or unacceptable for middle class housing" - located in close proximity to middle/high Income zones (Bailey, 2007, pp. 13-14). Future research could potentially expand the study to include other garrisons zones located within Jamaica. By incorporating other cases, valuable insight regarding the operational and power structure of the garrison could be obtained. It would also be fruitful to examine to what extend other criminal networks have modified their approach to criminal activities in the wake of the Tivoli Incursion.

Pertaining to the study of transnational crime within the Latin American and Caribbean, scholarship and policy setting currently tends to focus on the Latin American region at the expense of the Caribbean. This is because of the region's proximity to, and its history with, the U.S. There tends to be a focus on mainstream producers in Latin America such as Mexico, Colombia, Bolivia, and Peru. In the Caribbean, there is a focus on Jamaica, the Bahamas, Haiti and the Dominican Republic. However, little attention is given to: Guyana, The islands of the Eastern Caribbean, Belize, and Trinidad and Tobago. Each has become formidable transshipment points for marijuana and cocaine to countries across the globe (King N. A., 2013). How have these states managed to form alliances across the region? How do criminal entities negotiate with the state in order to [protect their business and to operate successfully.

The transnational nature of network based criminal groupings, indicates that criminal networks do not only have to be suppliers of illegal goods in order to

\footnotetext{
${ }^{80}$ The Uptown Low-Income Zone has conditions that are very similar to those found in the inner city. However, these Uptown Low-Income Zones are differentiated from the inner city by its close proximity to the Middle/High Income Zone.
} 
successfully compete in illegal markets. The case of Jamaica highlights how global forces have allowed criminal networks access to new markets and goods such as transnational violence. This allows criminal groups far removed from the production of illegal goods to play a critical role in the transshipment and distribution of illegal goods. Future research on transnational criminal networks should also pay equal attention to the formation of criminal groups, and the nature of their relationship with the states of Caribbean islands geographically positioned as key transshipment points for illegal activities.

Finally, future research suggests the need for a cross-national study on transnational criminal groups. It would be interesting to compare the experiences that various states have, with network-based transnational criminal groupings. Some attention, in the current study, is given to the growing trend of criminal transnational groupings occupying various localities; where an overview of the similarities between the Brazilian Favela typology and the Jamaican garrison typology is examined. This however sets the stage for a more thorough comparison of how criminal networks have successfully manage to gather support in urban-based communities by establishing and maintaining ties to political structures. One such example can be found in the case of Columbia and its comunas. 


\section{REFERENCES}

Adams, K. (2009). Indonesian Souvenirs as Micro-Monuments to Globalization and Modernity; hybridization, deterritorialization and commodification. In M. Hitchcook, V. T. King, \& M. Parnwell, Tourism in Southeast Asia: challenge and new directions. NIAS Press.

Aguirre Jr, A., Eick, v., \& Reese, E. (2006). Introduction: Neoliberal Globalization, Urban Privatization, and Resistance. Social Justice , 33 (3), 1-5.

Allen, C. (2006). Unruly Spaces: Globalization and Transnational Criminal Economies. In D. Conway, \& H. Nik, Globalization's Contradictions: Geographies of discipline, destruction and transformation. London: Routledge.

Amnesty International. (2009). Public Security Reforms and Human Rights in Jamaica. Retrieved September 5, 2013, from Amnesty International: www.amnesty.org/en/library/asset/AMR38/001/2009/en/353c5156-8749-41e18de9-fa9a611c9c2f/amr380012009en.pdf

Arias, E. D. (2006). The Dynamics of Criminal Governance: Networks and social order in Rio de Janeiro. Journal of Latin American Studies , 38 (2), 293-325.

Arias, E. D., \& Davis Rodriques, C. (2006). The Myth of Personal Security; A discursive model of local level legitimation in Rio's Favelas. Latin American Politics and Society, 48 (4), 53-81.

Associated Press. (2011, March 14). Fears of economic impact of earthquake, tsunami on Japan lead to broad sell-off on Wall Street. Retrieved September 21, 2013, from Masslive.com: www.masslive.com/news/index.ssf/2011/03/fears of a economic impact of.htm $\underline{1}$

Bagley, B. (2004). Globalization and Latin American and Caribeean Organized Crime. Global Crime , 6 (1), 32-53.

Bailey, C. (2007). Offender Travel In the Kingston Metropolitan Area, Jamaica. Kingston: University of the West Indies.

Bakan, A. B. (1990). Ideology and Class Conflict in Jamaica: The politics of rebellion. McGill-Queen;s Press.

Barclay, L. A., \& Girvan, N. (2008). Transnational Restructuring and the Jamaican Bauxite Industry: The swinging pendulum of bargaining power. Pre-Conference on the Global Ecnomic History of Bauxite. Paris. 
Basch, L., Glick Schiller, N., \& Szanton Blanc, C. (2003). Nations Unbound: Transnational projects postcolonial predicaments and deterritorialized nationstates. Routledge.

Baumol, W. J., Litan, R. E., \& Schramm, C. J. (2007). Good Capitalism, bad Capitalism, and The Economics of Growth and Prosperity. Yale University Press.

Bayat, A. (1997). Un-Civil Society: The politics of the 'informal people'. Third World Quarterly, $18(1), 53-72$.

Beckford, M. (2010, June 1). More Pressure on Dons. Retrieved September 30, 2013, from The Gleaner: jamaica-gleaner.com/gleaner/20100601/lead/lead8.html

Bernal, R. L. (1988). The Great Depression, Colonial Policy and Industrialization in Jamaica. Social and Economic Studies , 37 (1 and 2), 287-290.

Bertam, A. (2006, May 28). The 1938 Frome Labour Riots (part I). Retrieved September 22, 2013, from Jamaica Gleaner online: jamaicagleaner.com/gleaner/20060528/focus/focus5.html

Bertram, A. (2010a, October 31). Jamaican Higglers' Marketing System and the Future of Kingston (Part I). Retrieved September 30, 2013, from The Gleaner: jamaicagleaner.com/glenaer/20101031/focus/focus6.html

Bertram, A. (2010b, November 7). The Jamaican Higglers: Prosperity against the oddspart 2. Retrieved September 30, 2013, from The gleaner: jamaicagleaner.com/gleaner/20101107/focus/focus6.html

Bhabha, H. K. (1990). The Third Space: an interview with Homi Bhabha. In J. Rutherford, Identity, Community, Culture, Difference (pp. 201-213). London, UK: Lawrence and Wishert.

Black, S. (Director). (2003). Life and Debt [Motion Picture]. New York Video.

Bogues, A. (2002). Politics, Nation and Post Colony: Caribbean inflictions. Small Axe, $6(1), 1-30$.

Broad, K., \& Feinberg, B. (1995). Perceptions of Ganja and Cocaine in Urban Jamaica. J Psychoactive Drugs , 27 (3), 261-276.

Brooks, L. (2010, May 17). Engage Our Males Productively. Retrieved September 22, 2013, from The Jamaica Gleaner: jamaicagleaner.com/gleaner/20100517/business/business 1.html

Brown-Glaude, W. (2010, November 7). Jamaican Higglers:...Time for A New Story. Retrieved October 2, 2013, from The Jamaica Gleaner: jamaicagleaner.com/gleaner/20101107/focus/focus7.html 
Campbell, H. (2010, October 30). Flashback: 1980 general election, Ballot, Blood and Bullets. Retrieved September 22, 2013, from The Gleaner: jamaicagleaner.com/gleaner/20101030/news/news5.html

Cartwright, D. S., Tomson, B., \& Schwartz, H. (1975). Gang Delinquency. Brooks Cole.

Castells, M. (1999, March). Manuel Castells; cyber-scientist. (J. Gerstner, Interviewer) Communication World.

Castells, M. (1997). The Power of Identity, The Information Age: economy, society and culture (Vol. II). Cambridge, M.A: Blackwell.

Castells, M. (2000). The Rise of the Network Society. Oxford: Blackwell Publishers.

Charles, C. A., \& Beckford, O. (2012). The Informal Justice System in Garrison Constituencies. Social and Economic Studies , 61 (2), 51-72.

Charles, C. A., \& Beckford, O. (2012). The Informal Justice Sysytem in Garrison Constituencies. Social and Economic Studies , 61 (2), 51-72.

Chatt-A-Box. (2012, September 21). Killing Fields. Retrieved September 5, 2013, from Chatt-A-Box. A conversation: chatt-a-box.com/mywpblog/?p=3421

Chevannes, B. (2001). Crime and Drug-Related Issues in Jamaica. Souls: A critical journal of black politics, culture and society, 3 (4).

Chevannes, B. (2002). Learning to Be a Man: Culture, socialization and gender identity in five Caribbean communities. University of the West Indies Press.

CICAD. Comparative Analysis of Student Drug Use in Caribbean Countries: A report on student drug use in 12 Caribbean Countries. 2010: Organization of American States.

Clarke, C. (2006a). From Slum to Ghetto: Social deprevation in Kingston, Jamaica. International Development Planning Review (idpr) , 28 (1), 1-34.

Clarke, C. (2006b). Politics, Violence and Drugs in Kingston, Jamaica. Bulletin of Latin American Research, 25 (3), 420-440.

Cohen, J. L., \& Arato, A. (1994). Civil Society and Political Theory. MIT press.

Commentary. (2009, December 8). EDITORIAL- Government must honor its Treaty Obligations. Retrieved October 1, 2013, from The Jamaica Gleaner: mobile.jamaica-gleaner.com/20091208/cleisure/cleisure1.php 
Conway, D., \& Heynen, N. (2006). Globalization's Contradictions; geographies of discipline, destruction and transformation. London; New York: Routledge.

Cox, K. R. (1998). Spaces of Dependence, Spaces of Engagement and the Politics of Scale, or: looking glfor local politics. Political Geography, 17 (1), 1-23.

Creswell, J. W. (2009). Research Design: Qualitative, quantitative, and mixed methods approaches. Los Angeles: Sage Publications Inc.

Crichlow, M. A. (2005). Negotiating Caribbean Freedom: Peasants and the state in development. Lexington Books.

Daviot, K. (2012, September 18). Customs Boss Says Cocaine Trafficking Increasing in Jamaica. Retrieved October 1, 2013, from The Jamaica Gleaner: jamaicagleaner.com/latest/article.php?id=39997

Davis, C. E. (2012a, June 6). 60 Years of Bauxite Mining in Ja- Part II. Retrieved September 23, 2013, from The Jamaica Gleaner: jamaicagleaner.com/gleaner/20120606/news/news1.html

Davis, C. E. (2012b, June 5). 60 Years of Bauxite Mining in Jamaica- Part I. Retrieved September 23, 2013, from The Jamaica Gleaner: jamaicagleaner.com/gleaner/20120605/news/news1.html

Davis, M. (2006). Planet of Slums. Verso.

Davis, N. (2008, October 25). Haiti and Jamaica's Deadly Trade. Retrieved September 23, 2013, from BBC News: news.bbc.co.uk/2/hi/americas/7684983.stm

DEA. (1993, September). Coca Cultivation and Cocaine Processing: An overview. Retrieved September 22, 2013, from Schaffer Library of Drug Policy: www.druglibrary.org/schaffer/govpubs/cocccp.htm

DEA. (n.d.). Drug Enforcement Administration 1985-1990. Retrieved September 23, 2013, from DEA history: www.justice.gov/dea/about/history/1985-1990.pdf

Dennis, D. (2011, September 15). Seaga McKenzie amoung Mourners Praising 'Dudus's Mom. Retrieved October 1, 2013, from The Jamaica Observer: www.jamaicaobserver.com/news/Seaga--McKenzie-amoung-mourners-praising-Dudus-s-mom 9712300

Dialogo. (2013, January 2). Interview with Major General Antony Anderson, Chief of Defence Staff, Jamaica Defence Force. Retrieved September 23, 2013, from Dialogo: dialogoamericas.com/en_GB/articles/rmisa/features/regional_news/2013/02/01/featureex-3882 
Dicken, P. (2011). Global Shift: mapping the changing contours of the world economy. the Guilford Press.

Dogoodjamaica.org. (2011). Organizations: national housing trust. Retrieved September 30, 2013, from DOGOODjamaica: www.dogoofjamaica.org/organizations/national_housing_trust

Dreher, M. (2002). Crack Heads and roots Daughters: The therapeutic use of cannabis in Jamaica. Journal of Cannabis Therapeutics , 2, 121-133.

Dreher, M., \& Shapiro, D. (1994). Drug Consumption and Distribution in Jamaica: A national ethnographic study. Report submitted to U.S. Department of State. Kingston: United States Embassy.

Duncan-Waite, I., \& Woolcock, M. (2008). Arrested development: The political origins and socio-economic foundations of common violence in Jamaica. University of Manchester Press.

Durant-Gonzalez, V. (1983). The Occupation of Higglering (Vol. 16). Jamaica Journal.

Durant-Gonzalez, V. (1984). The Role and Status of Rural Jamaican Women: Higglering and mothering. University Microfilms.

Economic Commission for Latin America and the Caribbean. (2010). Report of the Macro Socio-economic Effects of the Events in Western Kingston Area, 22 may- 7 June 2010.

Eriksen, T. H. (2001). Tyranny of the Moment: fast and slow time in the information age. London: Pluto Press.

Estefan, F. (2009, January 19). Pan Colombia, Obama Style. Retrieved September 4, 2013, from Colombia Reports: colombiareports.co/plan-colombia-obama-style/

Fajnzylber, P., Lederman, D., \& Loayza, N. (1998). Determinants of Crime Rates in Latin America and the World: An Empirical Assessment. World Bank Latin American and Caribbean Studies Viewpoints.

Ferguson, B., \& Navarrete, J. (2003). New Approaches to Progressive Housing in Latin America: A key to habitat programs and policy. Habitat International , 27 (2), 309-323.

Fieser, E. (2010, June 1). Caribbean re-emerges as a drug corridor. GlobalPostInternational News.

Figueroa, M. (1985). An Assessment of Over Voting in Jamaican Elections. Social and Economic Studies , 34 (3), 71-106. 
Figueroa, M., \& Sives, A. (2002). Homogenous Voting, Electoral Manipulation and the 'Garrison' Process in Post-Independence Jamaica. Commonwealth \& Comparative Politics , 40 (1), 81-108.

Figueroa, M., Harriott, A., \& Satchell, N. (2008). The Political Ecnomy of Jamaica's Inner-City Violence: A Special Case? In J. Rivke, The Caribbean City. Kingston; Miami: Ian Randle Publishers.

Finchenauer, J. O., \& Voronin, Y. A. (2001, June). The Threat of Russian Organized Crime. Issues in International Crime.

Flick, U. (2007). Designing Qualitative Research. London: Sage Publications Ltd.

France 24. (2010, May 26). 'Dudus' Coke, Kingston's notorious 'Robin Hood'. Retrieved September 22, 2013, from France 24: International News 24/7: www.france24.com/en/20100526-dudus-coke-christopher-jamaica-robin-hoodwest-kingston-us-justice-drugs

Francis, J. (2013, July 5). Man up! Mountain View COmmunity Council Urges Young Men to Dream Big, Turn Away From Violence. Retrieved September 22, 2013, from The Gleaner: jamaica-gleaner.com/gleaner/20130705/lead/lead9.html

Francis-Jackson, C. (2009, January 16). Saying Goodbye to the US Ambassador. Retrieved October 2, 2013, from The Jamaica Gleaner: jamaicagleaner.com/gleaner/20090116/social/social2.html

Freidman, T. L. (2012). The Lexus and the Olive Tree: Understanding globalization. Picador.

Gibbs, G. R., Friese, S., \& Mangabeira, W. C. (2002). The Use of Technology in Qualitative Research Process. Forum Qualitative Sozialforschung/ Forum: Qualitative Social Research, 3 (2).

Giddens, A. (1990). The Consequences of Modernity. Cambridge: Polity.

Gillespie, K., \& McBride, J. B. (1996, Winter). Smuggling in Emerging Markets: Global implications. The Columbian Journal of World Business.

Gillham, B. (2000). Case Study Research Methods. London; New York: Continuum. Macpherson, K. (Producer), \& Gleaner, T. (Director). (2010). Coronation Market [Motion Picture].

Glennie, A., \& Chappell, L. (2010, June). Jamaica: From Diverse Beginning to Diaspora in the Devloped World. Migration Information Source: Fresh thought, authoritative data, gobal reach . 
Glick Schiller, N., Green Basch, L., \& Scanton Blanc, C. (1992). Towards a Transnational Perspective on Migration: race, class, ethnicity, and nationalism reconsidered. New York: New York Academy of Sciences.

GlobalSecurity.org. (2011, July 28). Intelligence: Jamaica. Retrieved September 22, 2013, from GlobalSecurity.org: www.globalsecurity.org/intell/ops/jamaica.htm

Goldstein, D. M. (2003). State Terror, Gangs, and zeveryday Violence in Rio de Janeiro. In D. M. Goldstein, Laughter Out of Place. University of California Press.

Gray, J. (1998). False Dawn; the delusions of global capitalism. The New Press.

Gray, J. (2005). The World is Round. The New Ypork Review of Books , 52 (13), 1-9.

Gray, O. (2004). Demeaned Empowered: The Social Power of the Urban Poor In Jamaica. Kingston, Jamaica: University of the West Indies Press.

Gray, O. (2003). Predation Politics and the Political Impasse in Jamaica. Small Axe , 7 (1), 72-94.

Grayson, K. (2010, June 3). Why Jamaica Proves that the 'War on Drugs' is Not Over. Retrieved September 5, 2013, from Chansing Dragons: www.chasingdragons.org/2010/06/why-jamaica-proves-the-war-on-drugs-is-notover.html

Griffith, I. (1997). Drugs and Security in the Caribbean: Sovereignty under siege. Penn State University Press.

Grindley, N. (2010, January 21). Higglers Selling Prescription Drugs on Streets. Retrieved September 30, 2013, from Jamaica Gleaner: jamaicagleaner.com/gleaner/20100121/lead/lead1.html

Grupta, A. (1995). Blurred Boundaries: The discourse of corruption, the culture of politics, and the imagined state. American Ethnologist , 22, 375-402.

Guildin, G. E. (2001). What's a Peasant to Do? Village becoming town in Southern China. Westview Press.

Gunst, L. (2003). Born fi' Dead: a journey through the Jamaican posse underworld. New York: H. Holt.

Hall, A. (2010, March 7). Power of a don-Putting politicians to shame. Retrieved September 22, 2013, from The Jamaica Gleaner: jamaicagleaner.com/gleaner/20100307/lead/lead2.html 
Hall, A. (2009, October 18). Trinidad Bound-Jamaican drug mules rush to the twin island republic. Retrieved September 23, 2013, from The Jamaica Gleaner: jamaica-gleaner.com/gleaner/20091018/lead/lead1.html

Hall, A. (2011, July 13). US Bars Dudus Pal-Embassy Revokes Justin O'Gilvie's Visa. Retrieved September 22, 2013, from The Jamaica Gleaner: jamaicagleaner.com/gleaner/20110713/lead/lead1.html?utm_source=twitterfeed\&utm_me dium=twitter

Hamilton, D. L. (2000). The Port Royal Project. Retrieved from Nautical Archaeology Program: http://nautarch.tamu.edu/portroyal/

Harlem World Magazine. (2009, June 22). Guns From America Fuel Jamaica's Gang Wars. Retrieved September 23, 2013, from Harlem World: harlemworldmag.com/2009/06/22/guns-from-america-fuel-jamaicas-gangwars/

Harriott, A. (2008). Organized Crime and Politics in Jamaica: breaking the nexus. Jamaica: Canoe Press.

Harriott, A. (2004). Understanding Crime in Jamaica: New Challenges for Public Policy. Kingston, Jamaica: University of the West Indies Press.

Harrison, F. V. (1997). The Gendered Politics and Violence of Structural Adjustment: A view from Jamaica. In L. Lampphere, H. Ragone, \& P. Zavella, Situated Lives: Gender and Culture in Everyday Life. New York, New York: Routledge.

Hart, K. (1973). Informal Income Opportunities and Urban Employment in Ghana. The Journal of Modern African Studies , 11 (1), 61-89.

Hart, R. (2002). Labour Rebellions of the 1930s in the British Caribbean Region Colonies. Caribbean Labour Solidarity and the Socialist History Society.

Harvey, D. (2005). A Brief History of Neoliberalism. Oxford Unversity Press.

Harvey, D. (2000). Spaces of Hope. Berkeley: University of California Press.

Harvey, D. (1991). The Condition of Postmodernity; An enquiry into the origins of cultural change. Wiley-Blackwell.

Haughton, S. A. (2011). Drugged Out: Globalisation and Jamaica' resilience to Drug Trafficking. University Press of America.

Headley, B. D. (1996). The Jamaican Crime Scene: a perspective. Washington DC: Howard University Press.

Hebron, L., \& Stack Jr., J. F. (2010). Globalization. Pearson. 
Held, D., McGrew, A., Goldblatt, D., \& Perraton, J. (1999). Global Transformations: politics, economics and culture. Stanford: Standford University Press.

Helps, H. G. (2013, August 25). "Dudus' vs Massop War Heats Up. Retrieved October 1, 2013, from the Jamaica Observer: www.jamaicaobserver.com/news/-Dudus--vsMassop-war-heats-up 14941075

Helps, H. (2012, October 30). The Bloody General Election that Changed Jamaica. Retrieved September 22, 2013, from Jamaica Observer: www.jamaicaobserver.com/news/the-bloddy-general-election-that-changedJamaica

Henry, M. (2010, June 20). Scrap the Constituency Development Fund. Retrieved September 30, 2013, from The Gleaner: jamaicagleaner.com/gleaner/20100620/focus/focus3.html

Henry, P. (2010, October 27). Jamaica Beating Back Corruption. Retrieved September 22, 2012, from Jamaica Observer: www.jamaicaobserver.com/news/jamaicabeating-back-corruption 8092610

Hill, K. (2011, November 7). Anti-Informer Culture Must Go. The Jamaica Gleaner .

Holder, E. (2010). Speech by Eric Holder Attorney General, United States of America. Washington, DC: Caribean Community (CARICOM).

Horowitz, R. (1987). Community Tolerance of Gang Violence. Social Problems , 34 (5), 437-450.

Hutton, W., \& Giddens, A. (2001). Global Capitalism. The New Press.

Hyland, J. (2002, January 11). Britain:Behind the roe over Jamaica "drug mules". Retrieved September 22, 2013, from World Socialist Web Site: www.wsws.org/en/articles/2002/01/jam-j11.html

Ishmael, A. O. (1996). A Caricom Position on the Drug Trade with Emphasis on the Situtation in Guyana. 19th session of the Inter-American Drug Abuse Control Commission (CICAD). Washington, DC.

Itzigsohn, J., Cabral, C. D., Hernandez Medina, E., \& Vazquez, O. (1999). Mapping Dominican Transnationalism: Narrow and broad transnational practices. Ethnic and Racial Studies , 22 (2), 316-339.

JCF Statistical and Data Management Unit. (2011). Jamaica Constabulary Force Periodic Major Crime Statistics Review. Retrieved September 4, 2013, from Jamica Constabulary Force: img860.imageshack.us/img860/8588/majorcrimereviewjan01ma.pdf 
(JMA), Jamaica Manufacturing Assocation. (2013, January 16). Manufacturers Make their Mark. Retrieved from The Gleaner: jamaicagleaner.com/gleaner/20130116/news5.html

Jamaica Botanical Department. (1887). Bulletin of the Botanical Department, Jamaica. Government Printing establishment.

Jamaica Has Record Number of Murders in 2009. (2010, January 12). BBC Monitoring Americas .

Jamaica Information Service. (2010, November 21). How the NHT Picks Mortgagors. Retrieved September 30, 2013, from The Gleaner: jamaicagleaner.com/gleaner/20101121/business/business8.html

Jessop, D. (2012, October 12). Narco Trafficking A Growing Threat. The Jamaica Gleaner.

Johnson, H. (2011). Challenges to Civil Society: Popular Protest \& Governance in Jamaica. Cambria Press.

Johnson, H. N. (2010). Towards Degarrisonisation in Jamaica: A place for civil society. Crime Prevention and Community Safety, 12 (1), 1-23.

Johnson, H. N., \& Soeters, J. L. (2008). Jamaican Dons, Italian Godfathers and the Chances of a 'Reversible Destiny'. Political Studies , 56, 166-191.

Johnson, H., \& Soeters, J. (2010, May 2). Informerphobia (part 1). The Jamaica Gleaner.

Jones, A. (2010). Globalization; key thinkers (Vol. 2 of PKS series). Polity.

Katzin, M. (1960). The Jamaican Country Higgler. Social and Economic Studies , 9 (3), 297-331.

Kearney, M. (1995). The Local and the Global: The antropology of globalization and transnationalism. Annual Review of Anthropology, 24, 547-565.

Keohane, R. O., \& Nye Jr., J. S. (2000). Globalization; whats new? whats not? (and so what?). Foreign Policy (118), 104-119.

Kerr, H. J. (1997). Report of the National Committee on Political Tribalism.

King, D. (2000). The Evolution of Structural Adjustment and Stabilization Policy In Jamaica. Government of Netherlands. 
King, N. A. (2013, March 16). CMCFeature--CARIBBEAN-US wants more done to deal with drug trade in the Caribbean. Retrieved October 2, 2013, from CANANEWS online: cananewsonline.com/features/87281-cmcfeature-caribbean-us-wantsmore-done-to-deal-with-drug-trade-in-the-caribbean.html

Klare, M. T. (2002). Resource Wars: the new landscape of global conflict with a new introduction by the author. Holt Paperbacks.

Klein, M. W. (1971). Street Gangs and Street Workers. Englewood Cliffs, New Jersey: Prentice-Hall.

Klein, M. W. (1995). The American Street Gang. New York, New York: Oxford university Press.

Lacy, T. (1977). Violence and Politics in Jamaica: 1960-70. Totowa, New Jersey: Frank Cass.

Laurent, B. (2007). Guns, Gangs and Governance (G3): Towards a comprehensive gang violence prevention strategy. Kingston: United States Agency for International Development.

Le Pichon, T., Pietschmann, T., Leggett, T., Johansen, R., Schmidt, A., Izadifar, D., et al. (2011, April). The Transatlantic Cocaine Market research paper. United Nations Office on Drugs and Crime.

Leckie, T. R. (2006, June 16). Enhancing the Jamaica Defence Force Military Intelligence Unit's Effectiveness to Conduct Counterdrug Missions. US Army Command and General Staff College.

Lefebvre, H. (1996). Writings on Cities. (E. Kofman, \& E. Lebas, Trans.) WileyBlackwell.

Leslie, G. (2010). Confronting the Don: The Political Economy of Gang Violence in Jamaica. Small Arms Survey, Graduate Institute of International and Development Studies. Geneva: Small Arms Survey.

Levinson, D. (2002). Encyclopedia of Crime and Punishment (Vols. 1-4). Thousand Oaks, California: Sage Publications Inc.

Levy, H. (2012, December 29). The Next 50 years- Communities, Local Govenrment and Development. Retrieved September 23, 2013, from The Jamaica Gleaner: jamaica-gleaner.com/gleaner/20121229/news/news2.html

Lund, C. (2006). Twilight Institutions: An introduction. Development and Change, 37 (4), 673-684. 
Luton, D. (2010, March 3). JLP Has Advantage In New Constituencies. The Jamaica Gleaner .

Macleod, M. J. (2007). Spanish Centeal America: A socioeconomic history, 1520-1720 (LLILAS Special Publications ed.). University of Texas Press.

Mahler, S. (1998). Theoretical and Empirical Contributions Towards a Research Agenda for Transnationalism. In M. P. Smith, \& L. E. Guarnizo, Transnationalism from Below. Transaction Publishers.

Manley, N. W., \& Nettleford, R. M. (1971). Norman Washington Manley and the New Jamaica: selected speeches and writings, 1938-68. Longman Caribbean.

Manwaring, M. (2007). A Contemporary Challenge to State Soverignty: gangs and other illicit transnational criminal organisations (TCOs) in Central America, El Salvador, Mexico, Jamaica, and Brazil. Strategic Studies Institute. Carlisle: United States War College.

Marshall, C., \& Rossman, G. B. (2010). Designing Qualitative Research. Los Angeles: Sage.

McFadden, D. (2011, March 11). Gunmen Shoot up Jamaica Police Post, Rob Hospital. Retrieved October 1, 2013, from The Washington Post: www.washingtonpost.com/wpdyn/content/article/2011/03/11/AR2011031105325.html

Meditz, S. W., \& Hanratty, D. M. (1989). Role Of Government. In S. W. Meditz, \& D. M. Hanratty, Islands of the Commonwealth Caribbean; A regional study. Washington, D.C: Federal Research Division Library of Congress.

Meeks, B. (2007). Envisioning Caribbean Futures: Jamaican Perspective. Kingston, Jamaica: Press University of the West Indies.

Meeks, B. (2000). Narrative of Resistence: Jamaica, Trinidad, the Caribbean. Kingston, Jamaica: Press University of the West Indies.

Meeks, J. (2009, June 30). Caribbean Children's Involvement in Gangs: Teleconference on research activities. Retrieved September 22, 2013, from UWI Open Campus: Consortium for Social Development \& Research: www.open.uwi.edu/sites/default/files/Carib_Children_CSDR 2030jun09.pdf

Miller, W. B. (1980). Gangs, Groups, and Serious Youth Crime. In D. Shichor, \& D. H. Kelly, Critical Issues in Juvenile Delinquency. U.S. Department of Justice. 
Mogensen, M. (2003). Corner and Area Gangs in Inner-City Jamaica. In L. Dowdney, Neither War nor Peace: International comaparisons of children and youth in organized armed violence. Children in Organized Armed Violence (COAV).

Moncrieffe, D. (1998). Gang Study: The Jamaican Crime Scene. Ministry of National Security and Justice. Kingston: Criminal Justice Research Unit.

Moravcsik, A. (2009). Robert Keohane: political theorist. In H. V. Milner, \& A. Moravcsik, Power, Interdependence, and Nonstate Actors in World Politics. Princeton and Oxford: Princeton University Press.

Moser, C. O., \& Holland, J. (1997). Urban Poverty and Violence in Jamaica. World Bank Publications.

Moyo, D. (2012). Winner take All: China's Race for Resources and What it Means for the World. Basic Books.

Munroe, T. (2000). Caribbean Thought and the Political Process. In D. Hall, \& K. Benn, Contending with Destiny: the Caribbean in the 21st Century. Kingston: Ian Randle Publishers.

Munroe, T. (1999). Renewing Democracy Into the Millennium: The Jamaican Experience in Perspective. Press University of the West Indies.

Munroe, T. (1972). The Politics of Constitutional Decolonization: Jamaica 1944-62. Institute of Social and Economic Research, University of the West Indies.

Naylor, R. (2004). wages of Crime: Black Markets, Illegal Finance, and the Underworld Economy. Cornell Univeristy Press.

Neuwirth, R. (2004). Shadow Cities: A Billion Squatters, A New Urban World. Routledge.

Nicolas, G. (2003, May). Brief History. Retrieved September 22, 2013, from Structure and Development of Kingston, Jamaica:

www.smartyoung.com/cities/kingston/brief history.htm

Noy, C. (2007). Sampling Knowledge: The hermeneutics of snowball sampling in qualitative research. International Journal of Social Research Methodology, 118.

Nye, J. S., \& Keohane, R. O. (1971). Transnational Relations and World Politics. International Organization , 25 (3), 721-748.

Orb, A., Eisenhauer, L., \& Wynaden, D. (2000). Ethics in Qualitative Research. Journal of Nursing Scholarship , 33 (1), 93-96. 
Patton, M. Q. (2002). Qualitative Research \& Evaluation Methods. Los Angeles: Sage.

Peck, J., \& Tickell, A. (2002). Neoliberalizing Space. Antipode, 34 (3), 380-404.

Pietrzyk, D. (2001). Civil Society-Conceptual History from Hobbes to Marx (Vol. Marie Curie Working Papers No. 1). International Politics.

Portes, A. (1995). The Economic Sociology and the Sociology of Immigration: A conceptual overview. In A. Portes, The Economic Sociology of Immigration: Essays on networks, ethnicity, and entrepreneurship. Russell Sage Foundation.

Portes, A., Guarnizo, L. E., \& Landolt, P. (1999). The Study of transnationalism: pitfalls and promise of an emergent research field. Ethnic and Racial Studies , 22 (2), 217-237.

Price, C. (2009). Becoming Rasta: Origins of rastafari identity in Jamaica. New York, New York: NYU Press.

Prior, L. (2003). Using Documents in Social Research (Vol. Introducing Qualitative Methods Series). Los Angeles: Sage.

Private Sector Organization of Jamaica. (2010). National Security Policy Paper: Improving National Security in Jamaica. Approved and Accepted by the Standing Committee on National Security.

Ramsey, G. (2012, February 22). Jamaica Minister: Street gangs primary causes of violence. Retrieved September 22, 2013, from Insightcrime: organized crime in the Americas: www.insightcrime.org/news-briefs/jamaica-minister-street-gangsprimary-cause-of-violence

Rao, V., \& Ibanez, A. M. (2003). the Social Impact of Social Funds In Jamaica: A moxed-methods analysis of participation, targeting, and collective action in community-driven development (Vol. issue 2970 of Policy research Working papers). Work Bank Publications.

Reid, T. (2013, March 3). \$280 for a Life. Retrieved September 23, 2013, from The Jamaica Gleaner: mobile.jamaica-gleaner.com/gleaner/20130303/lead/lead1.php

Reid, T. (2010, February 7). Boodshed on the Border: Women, children murdered across enemy lines. Retrieved September 22, 2013, from The Jamaica Gleaner: jamaicagleaner.com/gleaner/20100207/lead/lead1.html

Roache, A. (2010, May 21). Unemployment at Eight -Year High. Retrieved September 23, 2013, from Jamaica Observer: www.jamaicaobserver.com/business/Unemployment-at-eight-year-high 7633350 
Roberts, G. W. (1957). The Population of Jamaica. Kraus Reprint Company.

Roberts, G., Powell, D., Sinclair, S., Boland, B., \& Hewitt, L. (1974). Recent Population Movements in Jamaica. Census Research Programme of the zuniversity of the West Indies. CIRED.

Robinson, W. I. (2004). A Theory of Global Capitalism; production, class, and state in a transnational world. The Johns Hopkins University Press.

Robinson, W. I. (2010). Latin America and Global Capitalism: a critical globalization perspective. Johns Hopkins University Press.

Rodgers, D. (1999). Youth Gangs and Violence in Latin America and the Caribbean: A literature survey. The World Bank; Latin America and Caribbean Region Environmentally and Socially Sustainable Development SMU. Washington: The World Bank.

Rodney, W. The Abundance of Water: Sizzla Interview. Cool'Eh Magazine (14).

Rosenau, J. N. (2003). Distant Proximities: dynamics beyond globalization. Princeton University Press.

Rosenau, J. N. (1990). Turbulence in world Politics; a theory of change and continuity. Princeton, New Jersey: Princeton University Press.

Rotman, E. (2000). The Globalization of Criminal Violence. Cornell Journal of Law and Pubic Policy, 10, 1-43.

Ruggie, J. (1993). Territoriality and Beyond; Problematizing Modernity in International Relations. International Organization, 46.

Ryan, S. D. (1999). Winner Takes All: the Westminster experience inthe Anglophone Caribbean. St. Augustine, Trinidad \& Tobago: Press University of the West Indies.

Scheuerman, W. E. (2004). Liberal Democracy and the Social Acceleration of Time. Baltimore: Johns Hopkins Press.

Scholte, J. A. (2000). Globalization. A critical introduction. London: Palgrave.

Scholte, J. A. (1996). The Geography of Collective Identities in a Globalizing World. Review of International Politial Economy, 3 (4), 565-607.

Scholte, J. A., \& Schnabel, A. (2002). Civil Society and Global Finance. London: Routledge. 
Seelke, C. R., Wyler, L. S., Beittel, J. S., \& Sullivan, M. P. (2011, May 12). Latin America and the Caribbean: Illicit Drug trafficking and the U.S. Counterdrug Programs. CRC Report for Congress . Congressional Research Service.

Seita, A. Y. (1997). The Role of Market Forces in Transnational violence. Albany Law Review , 60, 635 .

Shakes, N. (2009). 76 King Street . Journal of Libery Hall: The legacy of Marcus Garvey , 1 .

Sheil, R., \& Davis, C. (2010, May 26). Kingston Residents Trapped Inside Homes as jamaican Death Toll Rises. Retrieved October 1, 2013, from theguardian: www.theguardian.com/world/2010/may/26/kingston-jamaica-dudus-coke

Shifter, M. (2007, February 1). Latin Americ's Drug Problem. Current History .

SIDSnet. (n.d.). Caribbean Region: Overview. Retrieved September 23, 2013, from SIDSnet: www.sidsnet.org/regions/18/Caribbean

Sikkink, K. (1993). Human Rights, Principled Issue-Netowrks, and Sovereignty in Latin America. International Organization , 47 (3), 411-441.

Sinclair, G. (2002, October 21). Bipartisan Peace bid in Mountain View war-Burke, McKenzie to meet gunmen. Retrieved September 22, 2013, from The Gleaner: jamaica-gleaner.com/gleaner/20021021/lead/lead6.html

Sinclair, G. (2013, May 16). Cops Target Assets- Investigators Eye \$300m in High-End Properties Thought to be Proceeds to Cocaine Trade. Retrieved October 1, 2013, from The Jamaica Gleaner: jamaicagleaner.com/gleaner/20130516/lead/lead1.html

Sinclair, G. (2008, January 13). Green Bay Survivors remember 30 years after the Massacre. Retrieved September 22, 2013, from The Gleaner: jamaicagleaner.com/gleaner/20080113/news/news3.html

Sinclair, G. (2005, March 18). 'We are at War'- August Town crackdown-13 high powered weapons seized, 'Sizzla' and 32 others detained. Retrieved September 22, 2013, from The Gleaner: jamaicagleaner.com/gleaner/20050318/lead/lead1.html

Sinclair, G., \& Spaulding, G. (2009, October 5). Dudus has Company-Extradition Files reveal prominent names- State says papers not ready for signature. Retrieved October 1, 2013, from The Jamaica Gleaner: mobile.jamaicagleaner.com/20091005/lead/lead1.php 
Sives, A. (2010). Elections, Violence and the Democratic Process in Jamaica 1944-2007. Kingston: Ian Randle Publishers.

Small, G. (1995). Ruthless. The global rise of the yardies. Warner.

Smith, M. M. (1996, June). Housing Finance in Jamaica: The national housing trust as a model for providing low-income housing? (Doctoral dissertation). Boston: Massachusetts Institute of Technology.

Smith, M. P. (1998). Looking for the Global Spaces in Local Politics. Political Geography, 17 (1), 35-40.

Smith, M. P. (2001). Transnational Urbanism: locating globalization. Wiley-Blackwell.

Smith, M. P., \& Guarnizo, L. E. (1998). The Locations of Transnationalism. In M. P. Smith, \& L. E. Guarnizo, Transnationalism from Below. Transaction Publishers.

Smith, M. P., \& Guarnizo, L. E. (1998). Transnationalism from Below (Vol. 6). Transaction Publishers.

Smith, R. C. (1998). Transnational Localities: Community, technology and the politics of membership within the context of mexico and U.S. migration. In M. P. Smith, \& L. E. Guarnizo, Transnationalism From Below. New Brunswick: Transaction Publishers.

Soja, E. (1996). Thirdspace: Journeys to Los Angeles and other real-and-imagined places. Ocford: Basil Blackwell.

Spaulding, G. (2009, September 13). One-on-one with: Dwight nelson taming the crime monster. Retrieved September 22, 2013, from The Jamaica Gleaner: jamaicagleaner.com/gleaner/20090913/lead/lead8.html

Spaulding, G. (2011, October 2). The Jamaica Gleaner. Retrieved October 1, 2013, from Will Golding's Tivoli Heir...Mash down Garrison Politics?: jamaicagleaner.com/gleaner/20111002/focus/focus51.html

Spaulding, G. (2013, March 10). Young Thugs on the Rise- West Kingston Residents Blame Families of Infamous Gangsters for Upsurge in Crime. Retrieved September 22, 2013, from The Gleaner: jamaicagleaner.com/gleaner/20130310/lead/lead1.html

Sprague, J. (2012, September 6). Reviving Haiti's Army would harm Democracy. Retrieved September 23, 2013, from Miami Herald: www.miamiherald.com/2012/09/06/2988432/reviving-haitis-army-wouldharm.html 
StabroekNews. (2010, May 12). Gangs Murdering their way Across Jamaica. Retrieved September 22, 2013, from Stabroeknews.com:

www.stabroeknews.com/2010/news/regional/05/12/gangs-murdering-their-wayacross-jamaica/

Standing, A. (2006). Organized Crime: A study from the Cape Flats. South Africa: Institute for Security Studies.

Standing, A. (2005). The Threat of Gangs and Anti-Gans Policy. Institute for Security Studies (116).

Statistical Insitute of Jamaica. (2011). 2011 Census of Population \& Housing- Jamaica. Retrieved September 4, 2013, from Statistical Institute of Jamaica: statinja.gov.jm/Census/Census2011/Census\%202011\%20from\%20website.pdf

Stockholm International Peace Research Institute. (2012). SIPRI Yearbook 2012: International Arms Transfer. Oxford University Press.

Stone, C. (1983). Democracy and Clientelism in Jamaica. New Brunswick: Transaction Books Publishers.

Stone, C. (1990). National Survey on the Use of Drugs in Jamaica. Mona: University of the West Indies.

Stupart, C. A., \& Shipley, R. (2012). Jamaica's Tourism: sun, sea and sand to cultural heritage. Journal of Tourism Insights , 3 (1).

Sullivan, M. P. (2010). Jamaica: Background and U.S. Relations. Congressional Research Service.

Taylor, C. S. (1990). Dangerous Society. Michigan: Michigan State University Press.

The Associated Press. (2010, May 24). Jamaica Declares State of Emergency after Gunfire Erupts in Drug Lord Stornghold. Retrieved October 1, 2013, from FoxNews.com: www.foxnews.com/world/2010/05/23/jamaica-police-urgealleged-drug-kingpin-surrener-barricade-stronghold/

The Jamaica Gleaner. (2010a, January 13). Dudus Still Wanted- US Govenrment will not withdraw request for Coke, but won't use power to get him extradited. Retrieved October 2, 2013, from The Jamaica Gleaner: jamaicagleaner.com/glenaer/20100113/lead/lead1.html

The Jamaica Gleaner. (2010b, February 26). Wayne Chen's US Visa Cancelled. Retrieved October 2, 2013, from The Jamaica Gleaner: jamaicagleaner.com/gleaner/20100226/lead/lead3.html 
The Jamaica Gleaner. (2010c, May 24). Attack on State- Policie Stations set Ablaze Cop Shot,Civilian Slain. Retrieved October 1, 2013, from The Jamaica Gleaner: jamaica-gleaner.com/gleaner/20100524/lead/lead1.html

The Jamaica Gleaner. (2010d, July 27). US to Rule On Ambassador To Jamaica Today. Retrieved October 2, 2013, from The Jamaica Gleaner: jamaicagleaner.com/gleaner/20100727/lead/lead3.html

The Jamaica Gleaner. (2012, May 6). Abortion for Sale- Black Marker Thrives on BabyKilling Pills. Retrieved September 30, 2013, from The Gleaner: http://jamaicagleaner.com/gleaner/20120506/lead/lead2.html

The Jamaica Observer. (2004, March 21). Out of the bowels of desperate poverty, a true Jamaican political sucess story is scripted. Retrieved September 23, 2013, from Jamaica Observer: www.jamaiaobserver.com/news/57420_Out-of-the-bowels-ofdesperate-poverty--a-true-Jamaican-political-sucess-

The Jamaica Observer. (2009, May 11). Gangs must be Crushed. Retrieved September 22, 2013, from Jamaica Observer: www.jamaicaobserver.com/news/151199 Gangs-must-be-crushed-

The Jamaica Observer. (2010a, April 11). US Agents Stream into Jamaica. Retrieved October 2, 2013, from The Jamaica Observer: www.jamaicaobserver.com/news/covert-agents-in-jamaica

The Jamaica Observer. (2010b, August 25). Small Contracts, Big Money. Retrieved September 30, 2013, from Jamaica Observer: www.jamaicaobserver.com/news/Small-contacts-big-money 7902179

The Jamaica Observer. (2011a, December 1). Jamaica Still Perceived as Corrupt. Retrieved September 22, 2013, from Jamaica Observer: www.jamaicaobserver.com/news/Jamaica-still-perceived-as-corrupt

The Jamaica Observer. (2011b, July 15). Customs Seize \$7.8 million in Illegal Cigarettes. Retrieved September 30, 2013, from Jamaica Observer: www.jamaicaobserver.com/NEWS/Customs-seize--7-8-million-illegal-cigarettes

The Jamaica Observer. (2012a, May 23). Complete Text of Cooperating Witness Statement Against 'Dudus'. Retrieved September 22, 2013, from Jamaica Observer: www.jamaicaobserver.com/news/Complete-text-of-cooperatingwitness-statement-against-Dudus-

The Jamaica Observer. (2012b, July 5). Norman Manley and SDC. Retrieved September 23, 2013, from Jamaica Observer: Column: www.jamaicaobserver.com/columns/Norman-Manley-and-SDC 11886360 
The Private Sector Organization of Jamaica (PSOJ). (2011). Position Paper on National Security. PSOJ.

Thomas, D. A. (2004). Modern Blackness: nationalism, globalization, and the politics of culture in Jamaica. Durham: Duke University Press.

Thomas, D. (2011). Exceptional Violence: Embodied citizenship in transnational Jamaica. Duke University Press.

Thomas-Hope, E. (2004). Migration Situation Analysis, Policy and Programme Needs for Jamaica. United Nations Population Fund. The Planning Office of Jamaica.

Thrasher, F. M. (2000). The Gang: A study of 1,313 gangs in Chicago. New Chicago School Press.

Tindigarukayo, J., \& Chadwick, S. J. (June 1999). Civil Service Reform in Jamaica. United Nations Development Program Report.

Tradingeconomics.com. (n.d.). Jamaica Unemployment Rate. Retrieved September 23, 2013, from Trading Economics: www.tradingeconomics.com/jamaica/unemployment-rate

U.S. Department of State. (2012). International Narcotics Control Strategy Report. Volume $1 \& 2$.

Ulysse, G. A. (2007). Downtown Ladies: Informal commercial importers, a Haitian Anthropologist and self-making Jamaica. University of Chicago Press.

United Nations. (2004). Globalization and State Capacity in the Asia-Pacific Region. UN/DESA Division for Public Economics and Public Administration.

United Nations Office on Drugs and Crime (UNODC). (2012, September). Transnational Organized Crime in Central America and the Caribdean: A Threat Assessment. Vienna.

United Nations Office on Drugs and Crime; Latin America and the Caribbean Region of the World Bank. (2007). Cime, Violence, and Development: Trends, Costs, and Policy Options in the Caribbean. UNODC; The World Bank.

United Nations Research Institute for Social Development. (1994, November). Ilicit Drugs: Social Impacts and Policy Responses.

United States Department of State. (March 2010). International Narcotics Control Strategy Report zvolume 1 Drug and Chemical Control. Bureau for International Narcotics and Law Enforcement Affairs. 
United States Department of State. (2011, June 27). Trafficking in Persons ReportJamaica. Retrieved September 5, 2013, from http://www.refworld.org/docid/4e12ee7032.html

United States Government Accountability Office. (2010). Merida Initiative: The United States has Provided Counternarcotics and Anticrime Support but Needs Better Performance Measures. Washington, DC.

UNODC. (2007). Crime, Violence, and Development: Trends, costs, and policy options in the Caribbean. Report No. 37820, A joint report by the United Nations Office on Drugs and Crime and the Latin America and the Caribbean Region of the World Bank.

UNODC. (2009). Why Does Cannabis Potency Matter? World Drug Report 2009 Series.

Urry, J. (2003). Global Compexity. Malden, MA: Polity.

Veillette, C. (2006, January 27). Andean Counterdrug Initiative (ACI) and Related Funding Programs FY2006 Assistance. CRS Report for Congress.

Vertovec, S. (2001). Transnational Social Formations: Towards conceptual crossfertilization. University of Oxford.

Vertovec, S. (2009). Transnationalism. Routledge.

Veseth, M. (2006). Globaloney; unraveling the myths of globalization. Rowman \& Littlefield Publishers.

Vigil, J. D. (1988). Barrio Gangs: Street life and identity in Sountern California. Austin, Texas: University of Texas Press.

Wasserman, S., \& Faust, K. (1994). Social Network Analysis: Methods and applicaitons (Vol. 8). Cambridge University Press.

Webb, G. (1999). Dark Alliance: the CIA, the Contras, and the crack cocaine explosion. New York: Seven Stories Press.

Wessel, D. (2010, April 8). Did "Great Recession" Live up to its Name? Retrieved September 23, 2013, from The Wall Street Journal: online.wsj.com/article/SB10001424052702303591204575169693166352882.html

Williams, E. E. (1969). The Negro in the Caribbean. Negro Universities Press.

Williams, L. (2004, July 5). Jamaica's Cocaine Story (Pt II). Retrieved September 22, 2013, from The Gleaner: jamaicagleaner.com/gleaner/20040705/news/news1.html 
Williams, L. (2004, July 4). Jamaica's Cocaine Story. Retrieved September 22, 2013, from The Gleaner: jamaica-gleaner.com/gleaner/20040704/lead/lead7.html

Wilson, H. (2010, March 17). Extradition and Ministerial Discretion. Retrieved October 1, 2013, from The Jamaica Gleaner: jamaicagleaner.com/gleaner/20100317/lead/lead7.html

Woodside, A. G. (2010). Case Study Research: theory, methods, practice. Emerald Group Publishing.

Yin, R. K. (2009). Case Study Research: design and methods (Vol. 5 of Aplied Social Research Methods). SAGE.

York, R. O. (1998). Conducting Social Work Research" an experimental approach. Allyn and Bacon.

Zatz, M. S., \& Portillos, E. L. (2000). Voices from the Barrio: Chicano/a gangs, families, and communities. Criminology, 38 (2), 369-402. 


\section{Appendix A}

\section{Interview Questions}

\section{Identifying whether the garrison is within or outside the confines of Jamaica civil society [garrison as it relates to civil society]}

1. When we speak of 'civil society', what do you take it to mean?

a. What are the strengths/limitations of the Jamaican civil society?

2. [In your opinion] Are criminal gangs, drug lords, and community dons located in the garrisons included in this civil society?

3. [In your opinion] Are there other members [aside from the criminal elements] of garrison communities [e.g.: unemployed, squatters] that should be included and or excluded in this civil society?

a. What members would be included or excluded?

4. What is your opinion of the role of civil rights groups such as Jamaica for Justice, Jamaica Coalition for Civil Society, Peace Management Initiative, and others in the garrison?

a. Do you consider these organizations successful? Why/why not?

Understanding the quality of governance in the garrison and how it impacts or directs the behavioral norms that manifest

5. When we speak of the 'garrison', what do you understand to mean?

6. Which individuals or groups do you consider responsible for the formation of the garrisons?

a. Beyond the individual(s) or group(s) mentioned, do you thing other individuals or groups have played a part in its formation, over time?

b. [In your opinion] How have these individuals or groups managed to influence the formation of garrisons?

i. [Just to be clear] Would you agree that the formation of garrison communities has been/has not been a collective effort over time?

7. [In your opinion] How do you consider power in garrison communities to be organized?

a. Is this power structure the only power structure that exists across garrison's communities?

i. What other power structures do you believe one could identify in the garrison communities?

8. [In your opinion] Do you think the image of the garrison has changed/evolved since its origin? 
a. Do you consider the image of the garrison; in general, has change been for the better or the worse? How so?

b. Do you think these changes have made the garrison stronger or weaker? In what ways?

9. On a scale of 1-10 with 5 indicating an opinion that is neither negative nor positive, how do you rate the overall performance of the various member of parliaments in providing for garrison communities.

a. What role do we see these individuals actually playing in garrison communities?

i. Do they play a role in these garrison communities on a day-to-day basis?

10. Is there a clear distinction between the criminal and legal elements that exist within garrison communities?

a. Can you expand on this?

b. Is there a marked difference between the actions undertaken by community leaders/dons in the garrison communities, versus community leaders in non-garrisoned communities?

i. Can you identify what these differences are?

\section{Political Economy-questions of political dynamic, social integration and finance}

11. How much political influence do you think community leaders/dons have in garrison communities today?

a. Do you think they have more, less or about the same as they did before the late 1970's and early 1980's? Can you expand on that?

12. How much economic influence do you think community/leaders/dons have in garrison community?

a. Do you think they have more, less or about the same as they did before the late 1970's and early 1980's? Can you expand on that?

13. It is commonly accepted that there is a history of community leaders/dons supporting specific Members of Parliament for office? However, in your opinion do you think there is also a history of Members of Parliament supporting garrison community leaders/Don's seeking positions of power?

14. [In your opinion] Do community leaders/dons typically need support from Members of Parliament in order to lead/govern their areas effectively?

a. Why do you say that?

15. Can you recall any [other] instances in which community leaders/dons and Members of Parliament have collaborated to achieve a common goal? If yes, what were the circumstances? 
16. [In your opinion] Do Members of Parliament typically include community leaders/dons in their inner circle?

b. [If yes], are these positions, positions of real influence?

17. In most garrison communities do you think the relations between community leaders/Dons and Members of Parliament are better, worse, or about the same than it was before the late 1970's and early 1980's?

a. Why do you think this is the case?

Understanding the role of governance structures [political, social, economic] in shaping behavior; also trying to understand agency and citizen responsibility

18. [In your opinion], do you believe that residents in garrison communities view community leaders/dons as independent individuals or as part of a larger organization/structure? Please explain?

19. [In your opinion], do you believe that the average Jamaican citizen views community leaders/dons within garrison communities as independent individuals or as part of a larger organization/structure? Please explain?

a. [If as part of a larger structure] when do you think this image changed?

\section{Questions about the Tivoli Invasion}

20. Were you involved in anyway in the Tivoli Invasion?

a. If so, what was your involvement?

21 . What is you most vivid memory of the event?

b. Do you see a difference between this event and other attempts by the state to infiltrate a garrison community?

22. During the time that this event took place; what did you think this event meant for state/garrisons relationship?

c. Since that event, to what extent has your feelings/perceptions about this event changed?

23. [In your opinion] To what extent do you think garrison residents in Tivoli Gardens were aware that they were going up against the Jamaican state and its legitimate right?

d. [In your opinion] Are there any other ways garrison members in Tivoli could have perceived the Tivoli incursion other than as an attack by the State? Could you expand on this?

e. [In your opinion] Do you think they perceived their offensive as a legitimate response to state action? How so? 
24. On a scale of 1-10 with 5 indicating an opinion that is neither negative nor positive, how do you rate the state's response or action during the Tivoli Invasion?

f. [If rating is below 5] In your opinion, what would have been an appropriate state response?

g. [If is above 5] What do you think would have made the state's response better?

25. In light of the Tivoli Incursion and in general, do you think media focus have weakened/strengthened the hold that community leaders/dons have on garrison communities? How so?

26. In light of the Tivoli Invasion and in general, do you think general attention to the area by international organizations and human rights groups have weakened/strengthened the hold that community leaders/dons have on garrison communities? How so?

27. In light of the Tivoli Invasion and in general, do you think the overall reactions of Civil Society as a collective have weakened/strengthened the hold that community leaders/dons have on garrison communities? How so?

a. Is there any specific faction of civil society whose reaction you would like to highlight?

28. [Do you think anti-criminal policies, by the Jamaican government/US such as the recently disbanded Operation Kingfish and the recently formed Major Organized Crime and Anti-Corruption Task Force (MOCA), make it difficult for illicit organizations tied to the garrison to run their business?

b. What if any other policies or initiatives come to mind?

29. In your opinion], are there any other factors that you believe would/could affect the hold that community leaders/dons have over garrison communities?

\section{Wrap up questions}

30. Given that this is a study on garrison communities, can you recommend anyone else who you think I should interview?

31. Thinking about everything that we have talking about today, do you think the interaction between garrison communities and the state play out differently from the interactions that take place between various communities in other countries?

32. Is there anything else you would like to add? Anything that I should have asked you but I did not ask? 


\section{Appendix B}

\section{Focus Group Discussion Questions}

\section{The Transnationalization of Garrisons and its Impact on the Jamaican State}

\section{Engaging Questions- understanding of civil society}

1. When we speak of civil society what you take it to mean?

a. What do you think are some of the strengths/limitations of Jamaican civil society?

2. Do you think civil society groups like Jamaicans for Justice and the PMI [Peace Management initiative] are doing a good job in helping people within garrison communities?

a. How so?

b. Are there any local community groups that you know of who are doing a good job/a better job?

\section{Exploration Questions- governance, sources of control/leadership}

3. We so often hear the term garrison, when we speak of garrison what do you understand it to mean? [What are we really talking about?]

4. Do you think the image of the garrison has changed over time?

a. How has it changed? [Clarify whether it's a good or bad change]

b. If it has not changed, why do you think this is the case?

5. How is power in garrison communities organized? [Who is really in charge in the garrison? - Don, Community Leader, Politician, Gang, etc.]

a. Are there challenges to this power? Is this/are these challenges typical?

6. Is there such a person as a Don in the garrison today? The person in control /community leader, can we still call him a Don, or should we call him something else?

a. If someone voices that the Don is obsolete, explore, who this new person is and how he is different for the "Don."

b. If the Don is still relevant, why do they think people say he is no longer important

7. How much political influence do you think community leaders* [whatever term the person in control identify as] have in garrison communities today

a. Do they have more, less or about the same since the Tivoli Incursion?

b. Do community leaders* need support from MP's in order to lead/govern their areas effectively?

8. How much economy influence do you think community leaders [whatever term the person in control identify as] have in garrison communities today

a. Do they have more, less or about the same since the Tivoli Incursion? 


\section{Exit questions- Interpretations of the Tivoli Incursion and its significance}

9. What is you most vivid memory of the Tivoli Incursion of May 2010?

a. Do you see a difference between this event and other attempts by the state to infiltrate a garrison community?

10. During the time that the Incursion took place, what did you think it meant for how the state normally treated garrison communities?

a. To what extent has your feelings/perceptions about this event changed?

11. Do you think the Jamaican state had a right to go into Tivoli?

12. Do you think Tivoli residents had a choice as to whether or not they would go up against the state?
a. Please expand

13. Is there anything else you would like to add? Anything that you think is important, but that has been overlooked as it related to the idea of the "garrison."

Thank you for your participation! 


\section{Appendix C}

\section{Contact Summary Form \& Field Notes}

\begin{tabular}{|l|l|}
\hline \multicolumn{2}{|c|}{ Contact Summary \& Field Notes Form } \\
\hline \multicolumn{1}{|c|}{ Focus Group \#_Location__ Todays date } \\
\hline $\begin{array}{l}\text { Name of primary contact } \\
\text { for Focus Group Contact } \\
\text { ( First, Last) }\end{array}$ & \\
\hline Contact's Title & \\
\hline $\begin{array}{l}\text { Focus group Interview } \\
\text { Date }\end{array}$ & \\
\hline $\begin{array}{l}\text { Focus Group Interview } \\
\text { Start time }\end{array}$ & \\
\hline $\begin{array}{l}\text { Focus Group Interview } \\
\text { End time }\end{array}$ & \\
\hline
\end{tabular}

1. Did anything strike you as salient, interesting, important, or particularly illuminating during this focus group?

2. Is there anything important or interesting that came out of the discussion that is not adequately reflected in the responses?

3. What were the main issues or themes that struck you in this contact? Address the following themes as well as any other themes that might have emerged.

Recount your observations and experiences from the interview. Reflection on body language and other subtitles. 


\title{
Appendix D
}

\section{Introduction Packet}

\section{FIU UNIVERSITY}

\author{
Michelle Munroe \\ $\mathrm{PhD}$ Candidate \\ FIU Modesto A. Maidique \\ Department of Politics and International Relations \\ SIPA $4^{\text {th }}$ Floor \\ 11200 SW 8th Street \\ Miami, FL 33199
}

$\underline{\text { Informational Letter }}$

\section{Dear Sir or Madam:}

My name is Michelle Munroe, and I am a student at Florida International University pursuing my Doctor of Philosophy Degree in Political Science. I invite you to participate in the fieldwork aspect of my dissertation titled: The Transnationalization of Garrisons and its Impact on the Jamaican State. Your public record of accomplishment has identified you as an individual whose views would be valued as a representative voice in Jamaica. The information that I hope to collect from interviewing you and other leaders across the country will culminate in the completion of my dissertation, which will explore the power dynamic that exists between the Jamaican state and Garri son Communities located in the Kingston Metropolitan Area.

I ask for your involvement in this study because the growth and evolution of the Garrison phenomenon in Jamaica, is at a tuming point. New circumstances and devel oping trends are prompting scholars in my field to reexamine frameworks and search for new answers. If researchers hope to understand and anticipate these changing paradigms, we need to hear from leaders like you. This phase of my research will involve interviews with a wide spectrum of civil society members, as well as Members of Parliament. My aim is to get your perspective on:

- Whether Garrisons, and its multiple features, is within or outside the confines of the Jamaican civil society

- The quality of governance in the garrison and how it impacts or directs the behavioral norms that manifest

- The current as well as historic political, economic, and social dynamic that exist between the Jamaican State and Garrison Communities

- The role of governance structures in shaping the boundaries of agency and citizen responsibility

- A refection on the Tivoli Incursion in 2011

The interview will be completely confidential and arranged to accommodate your schedule. It can be administered at any location most convenient to you and will take approximately 60 minutes of your time. In no way will data be released that would identify any individual or individual characteristics. While I realize that your time is valuable, there is no cost or payment for you as a subject. However, in order for this study to accurately reflect developing trends, your participation is especially important to this work and would be highly valued and greatly appreciated. I hope to schedule a time to meet with you at your earliest availability, up until August 4, 2012 at which point I am scheduled to leave the Island.

Additional information about me, along with my contact information is provided below. If you agree to participate in this research and you would like to obtain more information after your interview has been completed, please do not hesitate to ask. If you feel that you were mistreated or would like to talk with someone about your rights as a volunteer in this research study you may contact Dr. Patricia Price, the Chairperson of the FIU Institutional Review B oard at 305-348-2618 or 305348-2494.

Respect fully,

Michelle Munroe

$\mathrm{PhD}$. Candidate

Politics and International Relations

11200 S.W. $8^{\text {th }}$ Street $\bullet$ Miami, Florid a 33199 


\title{
Investigator Profile: Michelle Munroe
}

Biography

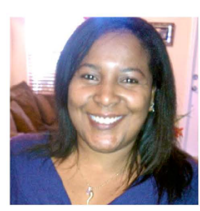

Contact Information

Michelle Munroe, PhD. Candidate, teaches and conducts research at the School of International and Public Affairs at Florida International University. She is a native of Kingston, Jamaica and graduated from the University of the West Indies in 2000 with a Bachelor's degree in Tourism Management. After working at a local resort for a few years, she decided to pursue her Masters in International Relations at the University of Florida. She later moved on to Florida International University where she is currently pursuing her $\mathrm{PhD}$. in Comparative Politics. Her primary research and interests include non-traditional security issues in the Caribbean and Latin America, the politics of development and underdevelopment in the developing world, and the study of identities in transnational contexts.

\author{
Michelle Munroe \\ $\mathrm{PhD}$ Candidate \\ FIU Modesto A. Maidique \\ Department of Politics and International Relations \\ SIPA $4^{\text {th }}$ Floor \\ 11200 SW 8th Street \\ Miami, FL 33199 \\ E-mail:mmunr001@fiu.edu; m_munroe_98@yahoo.com \\ Phone: 876-293-3680 \\ Dr. John Stack \\ Dissertation Committee Chair \\ Director of the School of International \& Political Affairs \\ FIU Modesto A. Maidique \\ SIPA 523 \\ 11200 SW 8th Street \\ Miami, FL 33199 \\ Email: Stackj@fiu.edu \\ Phone: 305-348-6561
}




\section{Appendix E}

\section{Elite Interviews Confidentiality and Quote Release Agreement}

FIU

INTERNATIONAL 3

UNIVERSITY

STUDY ON JAMAICA, GARRISONS, AND GLOBALIZATION

Reply form

YES, I think I will be able to particip ate. Contact me at the address below to discuss interview scheduling and further information.

POSSIBLY [Please use "comments" space below].

NO

Please enter your contact information

Salutation

First Name

Last Name

Suffix

Street

City

Parish

Phone

Email

Website

A dministrative contact (if different)

First Name Last Name

Phone

Email

Comments

Can you recommend another local leader whom we should try to interview this [time to be decided]?

First Name Last Name

Phone

Email

THANK YOU 


\section{FIU "romen UNIVERSITY}

\section{Study on Jamaica, Garrisons, and Globalization}

Confidentiality and Quote Release Agreem ent

I, the undersigned, have volunteered to be interviewed for the Study on Jamaica, Garrisons, and Globalization, which is under the direction of Michelle Munroe.

I hereby grant Michelle Munroe, $\mathrm{PhD}$ Candidate at the School of International and Public Affairs at Florida International University, permis sion to use quotes or words from my interview for publications produced from this research project. I relinquish and give her all rights, titles, and interest I $m$ ay have in the finished documents and publications.

I understand that the researchers on this study will keep all the information I provide completely confidential and, unless I grant permission to do so, will never link my quotes to my name.

I grant permission to have my real name and title linked to my quotations in publications produced from this rese arch project.

I do not wish to have my real name linked to my quotations. I understand that the only place my name and title will appear is in an appendix, along with the names of approximately 45 other respondents, in alphabetical order

I further understand that I may choose to skip any questions I do not wish to answer and may refuse to participate completely at any time. I understand that the interview will be audio recorded.

Signature

Date

11200 S.W. $8^{\text {th }}$ Street $\bullet$ Miami, Florid a 33199 


\title{
Appendix F
}

\section{Informational Letter for Focus Group}

\section{FII}

\author{
Michelle Munroe \\ $\mathrm{PhD}$ Candidate \\ FIU Modesto A. Maidique \\ Department of Politics and International Relations \\ SIPA $4^{\text {th }}$ Floor \\ 11200 SW 8th Street \\ Miami, FL 33199
}

Informational Letter

\section{Dear Sir or Madam:}

My name is Michelle Munroe, and I am a student at Florida International University pursuing my Doctor of Philosophy Degree in Political Science. I request your help in the fieldwork aspect of my dissertation titled: The Transnationalization of Garrisons and its Impact on the Jamaican State. I believe that with your assistance and through your affiliation with [name of organization or community] that I will have the best access to individuals residing with "garrison' communities whose views would be valued as a representative voice in Jamaica. The information that I hope to collect from interviewing these individuals will culminate in the completion of my dissertation, which will explore the power dynamic that exists between the Jamaican state and Garrison Communities located in the Kingston Metropolitan Area.

I ask for your involvement in this study because the growth and evolution of the Garrison phenomenon in Jamaica, is at a turning point. New circumstances and developing trends are prompting scholars in my field to reexamine frameworks and search for new answers. If researchers hope to understand and anticipate these changing paradigms, we need to hear from the people who reside within these communities and inner city areas.

In am interested in meeting with between 5-7 individuals who reside within a garrison community willing to share their views on:

a) How "garrison" residents feel about the Jamaican government.

b) How they think the Government perceives them as a community? As well as,

c) The term "Don" and the Don's place within garrison communities

d) Reflect on the Tivoli Incursion of May 2010

A colleague, who represents my research and me, will conduct the focus group. Her name is Nicole WarmingtonGranston and she will be in Kingston from February 18 - March 1, 2013. She will be able to conduct this focus group on any day during that timeframe, at a time and location most convenient for the participants. I sincerely hope that you will be able to assist me in this matter, as this focus group is especially important to my work and would be highly valued and greatly appreciated.

Please find my contact information attached below, if you have any questions or concerns please do not hesitate to let me know. Mrs. Blarosington-Granston will be contacting you in the next couple of days/to introduce berself, establish local contact, confirm your assistance, and to schedule the focus group.

Respectfully,

Michelle Munroc

$\mathrm{PhD}$. Candidate,

Politics and International Relations 


\title{
Appendix G
}

\section{Focus Group Confidentiality and Quote Release Form}

\author{
$10 \mid \begin{aligned} & \text { FLORIDA } \\ & \text { INTERNATIONAL }\end{aligned}$ \\ UNIVERSITY \\ Focus Group Consent Form \\ The Transnationalization of Garrisons and Its Impact on the Jam aican State
}

You have been asked to partici pate in a research study. This form provides you with information about the study. Members of my research team will conduct this study and they will be available to answer all of your questions. Please read the informati on below. Your participation is voluntary and you are free to leave at any time. If you choose to do so, any information derived from your participation will be deleted from the evaluation findings

Purpose of the study is to:

- Learn about the quality of governance within garrison communities

- Explore the term "D on" and better understand the Don's place within garrison communities

- Refl ect on the Tivoli Incursion of May 2010 and explore how residents from various garrison communities see its affect

Your involvement: You are being asked to participate in a discussion with other residents of garrison communities, in order for the principal researcher to understand the opinions of the people who reside within "Garrison Communities." The discussion will last approximately 90 mins, and it will be audio taped. The audi otape will then be transcribed to ensure accurate reporting of the information you provide

Confidentiality: All information gathered from the study will remain confidential. Y our identity as a participant will not be disclosed to any unauthorized persons. Further, the real names of individuals will not be used in the study. Transcribers will sign a form stating that they will not discuss any item on the tape with anyone other than the researchers. No one's name will be asked or revealed during the focus groups. However, should another participant call you by name, the transcriber will be instructed to remove all names from the transcription. Only the investigator will have access to the information and it will be kept in a locked drawer.

Possible Benefits: One potential benefit of participating in this study is that you will have an opportunity to describe your experiences and opinions with others who share the same experiences. The opportunity to connect and share similar experiences with others may help to highlight community strengths and weaknesses, and ultimately may contribute to existing or future forms of community-based coalitions. This research is expected to help scholars and policymakers make better decisions and to better understand the circumstances of individuals who live within the Garri sons. There are no inherent risks associated with participating in this study.

Contact for questions: If you have any questions regarding the study or the discussion process please contact the Principal Researcher, Michelle Munroe at 305-394-5015. If you feel that you were mistreated or you would like to talk to someone about your rights as a volunteer in this research project, you may contact Dr. Patricia Price, the Chairperson of the FIU Institutional Review Board at 305-348-2618 or 305-348-2494.

This agreement states that you have received a copy of this informed consent. Your signature below indicates that you understand the terms as stated in this consent form and that you agree to participate in this study. Thank you for taking the time out of your busy schedule to consider participation.

Subject name(Printed)

$\overline{\text { Signature of Investigator }}$

$\overline{\text { Date }}$

11200 S.W. $8^{\text {th }}$ Street * Miami, Florid a 33199 


\section{Appendix $\mathbf{H}$}

\section{List of Research Participants from Interviews}

Nancy M. Anderson

Robert Buddan

David J. Campbell

Christopher Charles, $\mathrm{PhD}$

J. Carolyn Gomes

Martin Henry

Damian Hutchinson

Horace Levy

Joseph M. Matalon

Trevor Munroe, PhD.

Carol Narcisse

John Rapley
Attorney, Legal Aid Clinic at Norman Manley law School;

Legal officer, Independent Jamaican Council for Human

Rights

Lecturer, UWI; Columnist, the Jamaica Gleaner

Founder, Fusion Caribbean

Lecturer, University of the West Indies (UWI)

Executive Director, Jamaicans for Justice (JCJ)

Columnist, the Jamaica Gleaner

Program Manager, Peace Management Initiative (PMI)

Executive member, (PMI); Board of Director, (JCSC)

Former president, Private Sector Organization of Jamaica (PSOJ)

Professor, University of the West Indies; Executive

Director, National Integrity Action (NIA)

Chairman, Jamaica Civil Society Coalition (JCSC)

Political Economist, Centre for Development Studies, University of Cambridge; Foreign Affairs Columnist, the Jamaica Gleaner 
Mark Shields

Milton Tomlinson

Bobby Wilmot, Reverend

Neville I. Wright, Pastor
Former Deputy Commissioner of Police; Security

Consultant, Shields Crime \& Security Consultants Ltd $(\mathrm{SCSC})$

President, Mountain View Community Council; member (PMI)

Founder, Joy Town Learning Center; Pastor

Councilor for Trench Town Division; Pastor 
VITA

\section{MICHELLE MUNROE}

$1996-2000$

2000-2002

2002-2004

2004-2005

2005-2013

2006-2009

July 2007

August 2007
B.Sc., Tourism Management University of the West Indies Mona Campus, Jamaica

Guest Service Manager, Franklyn D. Resort Runaway Bay, Jamaica

M.A., International Relations

University of Florida

Gainesville, Florida

Intern, Land Use Assessment and Development Report Sustainable Alachua County Inc Gainesville, Florida

Doctoral Candidate Department of Politics and International Relations Florida International University Miami, Florida

Teaching Assistant Department of Politics and International Relations Florida International University Miami, Florida

Field Interviewer and Research Assistant on Harvard Study on Local Black Elites in the city of North Miami Harvard University Cambridge, Massachusetts

Study Abroad Spain, National Security Studies (PINSS) Foreign Language and Cultural Immersion Scholarship Jack D. Gordon Institute for Public Policy Florida International University Miami, Florida 
Instructor, Politics of Development and Underdevelopment, Comparative Politics

Florida International University

Miami, Florida

2011

Recipient, Broad Research Fellowship

2011

Recipient, Dissertation Evidence Acquisition Fellowship

2011-2013

Teaching Assistant, Interdisciplinary Writing Assistantship Department of English

Florida International University

Miami, Florida

2013-present

Instructor, Writing and Rhetoric I, Politics of Development and Underdevelopment, Comparative Politics, International Relations, Florida International University Miami, Florida

\section{PUBLICATIONS AND PRESENTATIONS}

Munroe, M. (March, 2006). Power and Tourism. Unpublished paper presented at the Annual Latin American 7 Caribbean Studies Graduate Students Conference, Miami, FL

Munroe, M. (February 2007). Haiti, Transitions Less than Democratic. Unpublished paper presented at XXVII Annual ILASSA Student Conference, Austin, Texas

Munroe, M. (April 2007). In Pursuit of Democracy and the Dream of a Nation-State: The case of Jamaica. Unpublished paper presented at $65^{\text {th }}$ Annual Midwest Political Science Association Conference, Chicago, IL

Munroe, M. (April 2010). Renegotiating Relationships between the State and Society: Jamaica, garrisons and globalization. Unpublished paper presented at $68^{\text {th }}$ Annual Midwest Political Science Association Conference, Chicago, IL

Munroe, M. and Warmington-Granston, N. (October 2013). The United States and CARICOM Relations Revisited: Insights into a post September $11^{\text {th }}$ Era. Unpublished paper presented at presented at the SALISES Regional Integration Conference, Kingston, Jamaica 